\title{
Understanding the ocean carbon and sulfur cycles in the context of a variable ocean: a study of anthropogenic carbon storage and dimethylsulfide production in the Atlantic Ocean
}

\author{
by \\ Naomi Marcil Levine \\ A.B. summa cum laude in Geosciences \\ Princeton University, 2003 \\ Submitted in partial fulfillment of the requirements for the degree of \\ Doctor of Philosophy \\ at the \\ MASSACHUSETTS INSTITUTE OF TECHNOLOGY \\ and the \\ WOODS HOLE OCEANOGRAPHIC INSTITUTION
}

February 2010

(C) 2010 Naomi Marcil Levine. All rights reserved.

The author hereby grants to MIT and WHOI permission to reproduce and to distribute publicly paper and electronic copies of this thesis document in whole or in part in any medium now known or hereafter created.

Signature of Author

Joint Program in Oceanography Massachusetts Institute of Technology and Woods Hole Oceanographic Institution

October $9^{\text {th }}, 2009$

Certified by

Dr. Scott C. Doney

Thesis Co-supervisor

Certified by

Dr. Dierdre Toole

Thesis Co-supervisor

Accepted by

Dr. Roger Summons

Chair, Joint Committee for Chemical Oceanography 


\title{
Understanding the ocean carbon and sulfur cycles in the context of a variable ocean: a study of anthropogenic carbon storage and dimethylsulfide production in the Atlantic Ocean \\ by \\ Naomi Marcil Levine
}

Submitted to the Department of Marine Chemistry and Geochemistry, Massachusetts Institute of Technology- Woods Hole Oceanographic Institution Joint Program in Chemical Oceanography

In partial fulfillment of the requirements for the degree of

Doctor of Philosophy

\begin{abstract}
Anthropogenic activity is rapidly changing the global climate through the emission of carbon dioxide. Ocean carbon and sulfur cycles have the potential to impact global climate directly and through feedback loops. Numerical modeling, field and laboratory studies are used to improve our mechanistic understanding of the impact of natural variability on carbon and sulfur cycling. Variability in ocean physics, specifically changes in vertical mixing, is shown to significantly impact both cycles. The impact of interannual variability on the detection and attribution of anthropogenic carbon $\left(C_{\text {anthro }}\right)$ and the storage of $\mathrm{C}_{\text {anthro }}$ in the Atlantic Ocean is analyzed using a three-dimensional global ocean model. Several regions are identified where empirical methods used to estimating $C_{\text {anthro }}$ are not able to correct for natural variability in the ocean carbon system. This variability is also shown to bias estimates of long term trends made from hydrographic observations. In addition, the storage of $C_{\text {anthro }}$ in North Atlantic mode waters is shown to be strongly influenced by water mass transformation during wintertime mixing events.

The primary mechanisms responsible for seasonal variability in dimethylsulfoniopropionate (DMSP) degradation and dimethylsulfide (DMS) production in the oligotrophic North Atlantic are investigated using potential enzyme activity and gene expression and abundance data. Vertical mixing and UV radiative stress appear to be the dominant mechanisms behind seasonal variability in DMS production in the Sargasso Sea. This thesis demonstrates the importance of and dynamics of bacterial communities responsible for DMSP degradation and DMS production in oligotrophic surface waters. These findings suggest that modifications to current numerical models of the upper ocean sulfur cycle may be needed. Specifically, current static parameterizations of bacterial DMSP cycling should be replaced with a dynamic bacterial component including DMSP degradation and DMS production.
\end{abstract}

Thesis Supervisor: Scott C. Doney

Title: Senior Scientist, Woods Hole Oceanographic Institution

Thesis Supervisor: Dierdre Toole

Title: Assistant Scientist, Woods Hole Oceanographic Institution 


\section{Acknowledgements}

My graduate research was supported by a Linden Earth Systems Graduate Fellowship (MIT), a Department of Defense NDSEG fellowship, an EPA STAR fellowship, the Scurlock Fund, and the Ocean Venture Fund. Additional funding for this work was provided by the National Science Foundation (OCE02-23869, OCE-0623034, OCE-072417, OCE-0525928, OCE-0425166), the Gordon and Betty Moore Foundation, and the Center for Microbial Oceanography Research and Education (CMORE) an NSF Science and Technology Center (EF-0424599).

I was fortunate to have had the opportunity to work with and learn from two fantastic advisors. Scott Doney has been a wonderful mentor and teacher and has pushed me to be the best scientist I could be. Dierdre Toole introduced me to the world of sulfur, and supported me through the ups and downs of time-series research. I am also extremely grateful to both of my committee members- Mary Ann Moran who opened her lab to me and provided an endless supply of advice and optimism (without her there would be no Chapter 5), and Mick Follows for his support and limitless enthusiasm.

This thesis would not have been possible without Vanessa Varaljay and Aimee Neeley. Aimee participated on all of the BATS cruises with me and made much of the concentration and rate measurements presented in Chapter 5. The qPCR work would not have been possible without Vanessa's guidance and help. The long hours on the boat and in lab went by quickly due to the great company and friendship of these two women.

The carbon modeling work presented in this thesis benefited significantly from the help of Dave Glover, Ivan Lima, and the rest of the Doney lab. Dave is an invaluable resource and always seems to have the answer no matter how obscure the question. Ivan was an enormous help- always willing to extract data no matter how short the time frame. I would also like to thank Rik Wanninkhof, Inez Fung, Keith Lindsay, Chris Sabine, and Richard Feely,

I am indebted to the generous staff at WHOI whose doors were always open. In particular, I need to thank John Dacey, Ben van Mooy, Liz Kujawinski, Marco Coolen, Karen Casciotti, Mak Saito, John Waterbury, and Dan Repeta for opening their labs to me. In addition, Dan Rogers, Erin Banning, Matt McIlvin, Carl Lamborg, Freddy Valois, Helen Fredricks, Krista Longnecker, and Nan Trowbridge were always willing to help me tackle whatever hurdle was in front of me.

Over the course of my $\mathrm{PhD}$, I spent the good portion of two years at the Bermuda Institute of Ocean Sciences and on board the $R / V$ Atlantic Explorer. The staff at BIOS and the captain and crew of the AE were both welcoming and generous and truly made Bermuda feel like a home-away-from-home. Specifically I need to thank Nick Bates, Mike Lomas, Rod Johnson, Rachel Parsons, Craig Carlson, Nina Nemcek, Amanda Burke, Jonathan Whitefield, Steve Bell, Natasha McDonald, Andreas Andersson, Lilia Jackman, Dave Siegel, Norm Nelson, Dane Percy, and the rest of the BATS team. In 
addition, during the BATS cruises I enlisted the help from numerous people including Nicole Benoit, Stephanie Owens, Andrew McDonnell, and the POGOnians.

All of the RNA and DNA samples were processed at the University of Georgia in the Moran lab. From the graduates students and post-docs to summer students to support staff, everyone was incredibly welcoming. I am grateful to have had the opportunity to work with such a wonderful group of scientists. Specifically I would like to thank Erinn Howard, Maria Vila-Costa, Scott Gifford, Ira Tigner, Chris Reisch, and Johanna Rinta Kanto.

As Joint Program students we are spoiled by an exceptional support staff. Julia Westwater, Marsha Gomes, Christine Charette and the rest of the Academic Programs Staff not only solved any problem that raised its head but were always there with a word of encouragement and a smile. Similarly, Sheila Clifford, Donna Mortimer and BL Owens were always there to lend a hand and help tackle any problem.

My time at WHOI has been enriched by the support and friendship of a wonderful group of fellow Joint Program students. In particular, Nathalie Goodkin, Kristin Pangallo, Rachel Stanley, and Helen White who were with me every step of the way from Winding Lane to Wright Hall, from the general exam to my thesis defense- thank you.

I have been truly blessed to have a Princeton family, which has supported me through the ups and downs of the past 5 years. While they may not have always understood what kept me going back to Bermuda, they were always there to welcome me home with open arms. To my roommates (Dan and Matty) and my girls (Kate, Kate, Pam and Beth) who provided an escape from lab, a bottomless source of support, and unconditional love- thank you for being the best friends I could ask for. And to Nathalie, thank you for being a true friend, colleague, confidant, and cheerleader.

I would not be who or where I am today without my family, Mom, Dad and Sylvie, who showed me the world and taught me to explore it- thank you for nurturing my inner scientist and for keeping the rest of me whole and happy. And to my husband and best friend Alex who has lived with the constant travel, the late nights working in lab, and the endless trouble shooting- thank you for believing in me even when I doubted myself. 


\section{Table of Contents}

List of Tables $\quad 11$

List of Figures $\quad 12$

$\begin{array}{ll}\text { Introduction } & 17\end{array}$

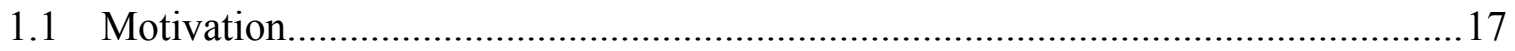

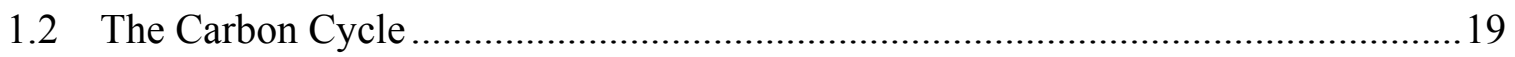

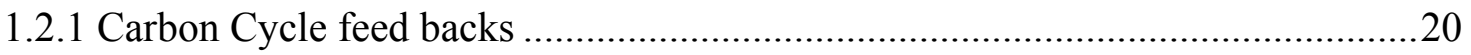

1.2.2 Estimates of the ocean carbon sink ..............................................................22

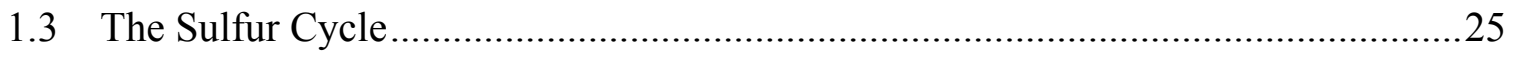

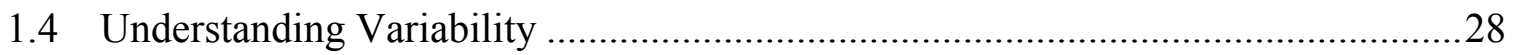

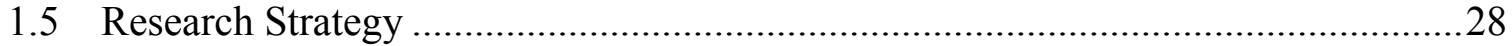

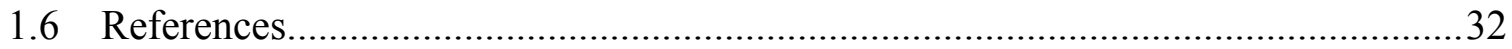

\section{The Impact of Ocean Carbon System Variability on the Detection of Temporal} $\begin{array}{ll}\text { Increases in Anthropogenic } \mathrm{CO}_{2} & 37\end{array}$

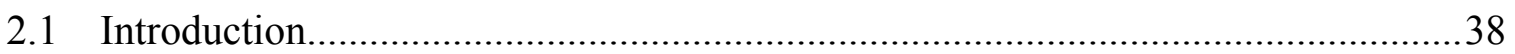

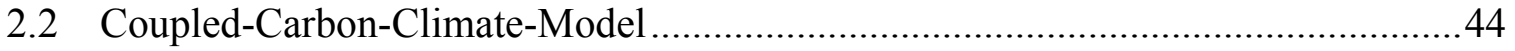

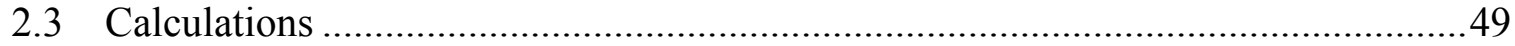

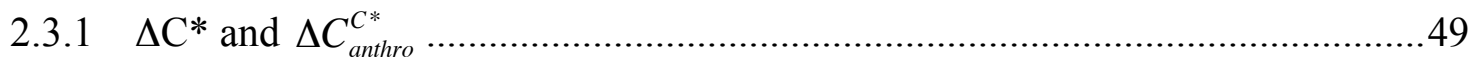

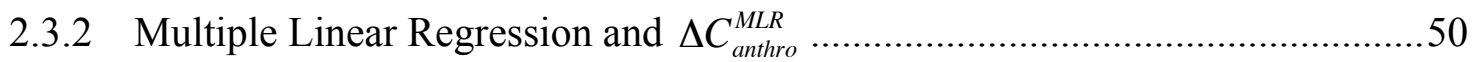

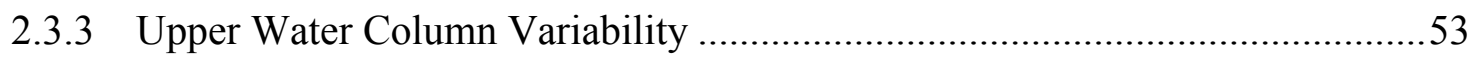

2.4 Removing Natural Variability in the Model Ocean Carbon System .......................54

2.5 Detecting and Attribution of Temporal Trends in Anthropogenic $\mathrm{CO}_{2} \ldots \ldots \ldots \ldots \ldots . . .56$

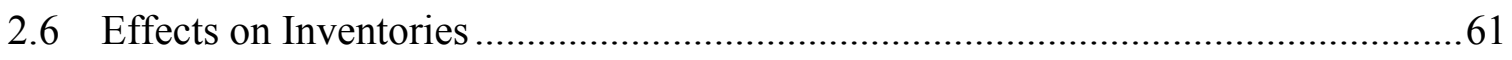




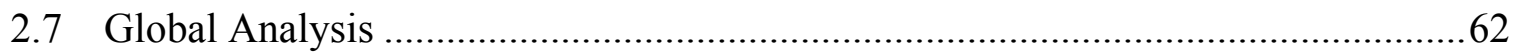

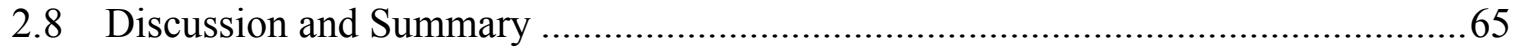

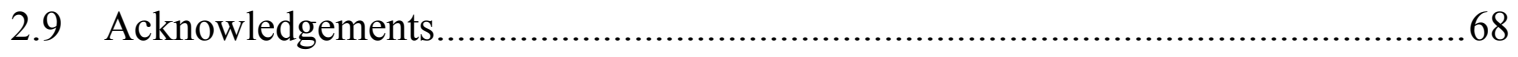

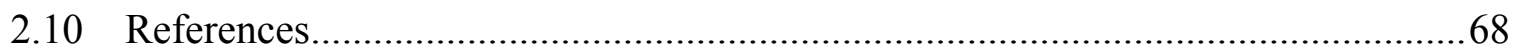

The Impact of Interannual Variability on the Uptake and Accumulation of Anthropogenic $\mathrm{CO}_{2}$ in the North Atlantic $\quad 89$

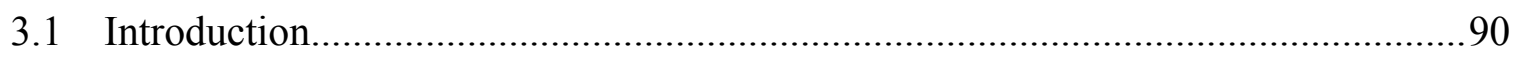

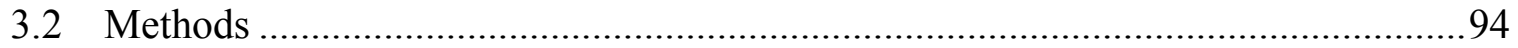

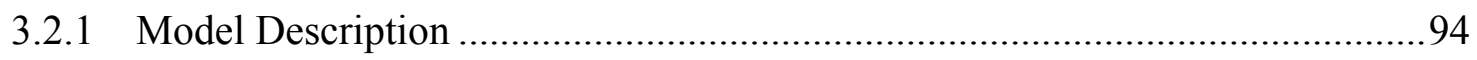

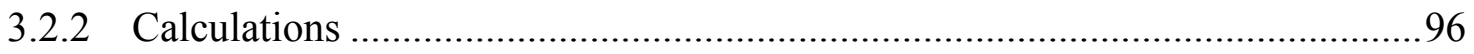

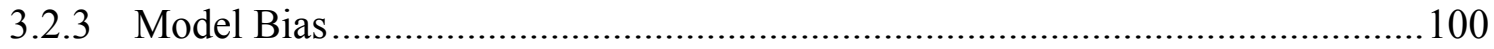

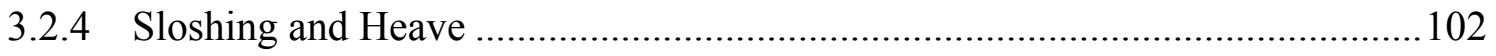

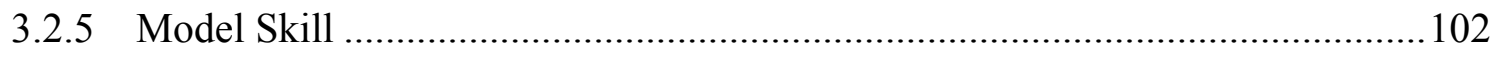

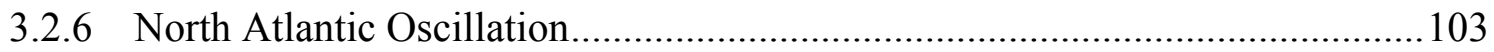

3.3 Interannual variability in North Atlantic $C_{\text {anthro }}$ storage ...........................................105

3.4 Mechanisms governing interannual variability in the subtropical gyre.....................108

3.5 Mechanisms governing interannual variability in the subpolar gyre.........................111

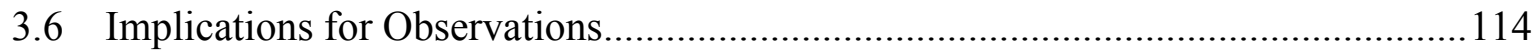

3.6.1 Anthropogenic carbon versus total carbon .................................................115

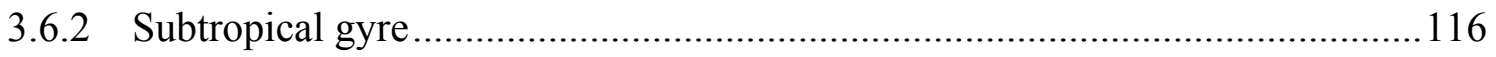

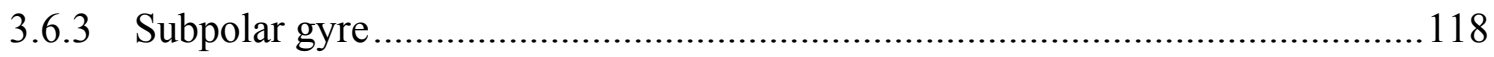

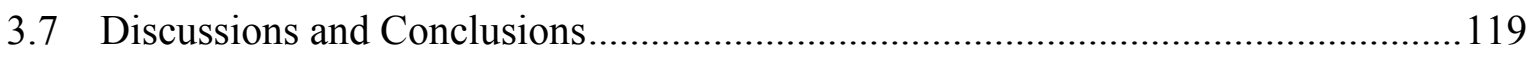

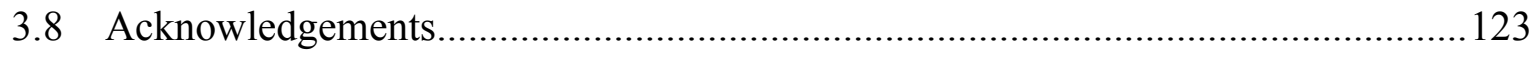

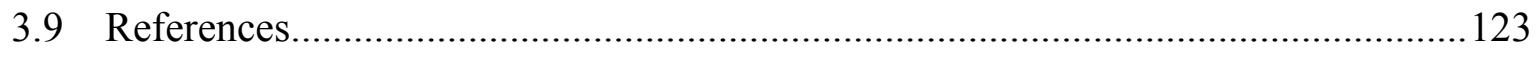

The Upper Ocean Sulfur Cycle: Introduction and Methods $\quad 147$

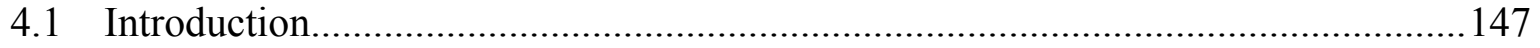

4.1.1 Overview of the upper ocean sulfur cycle ........................................................147 


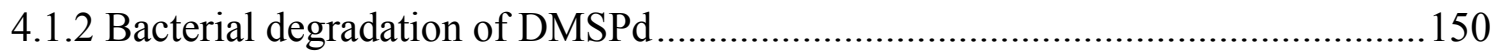

4.2 Bermuda Atlantic Time-series Study (BATS)...................................................154

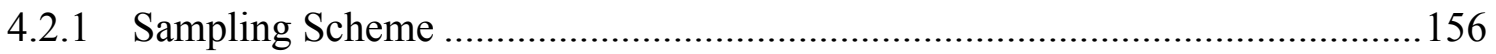

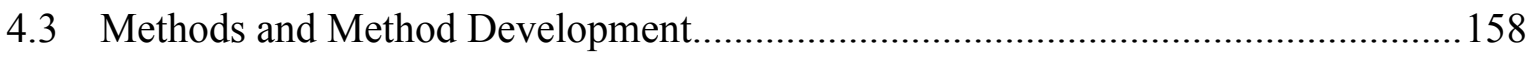

4.3.1 Concentration and Rate Measurements ………….............................................158

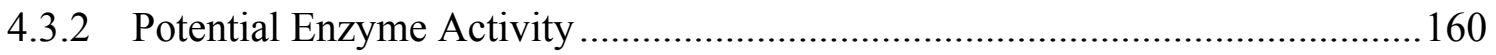

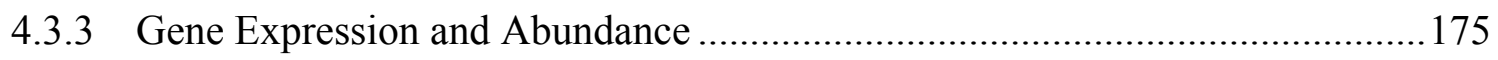

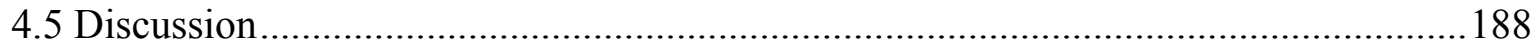

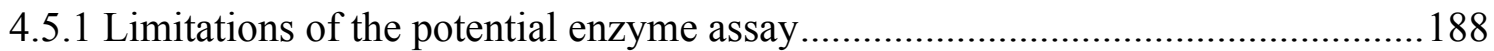

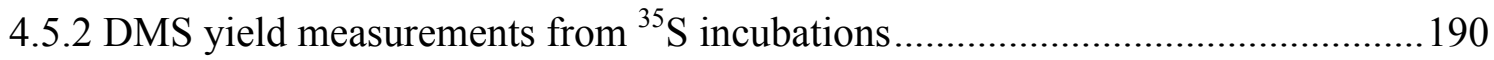

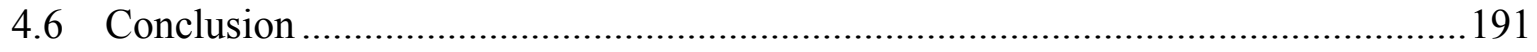

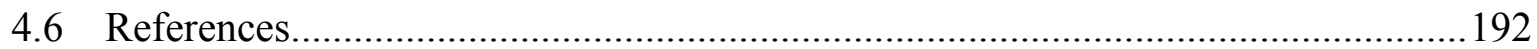

The Upper Ocean Sulfur Cycle: Understanding the key bacterial and phytoplankton functional groups involved in DMSP degradation 211

5.1 Introduction: The Summer Paradox and the Seasonal Sulfur Cycle at the Bermuda Atlantic Time-series Study site ......................................................................211

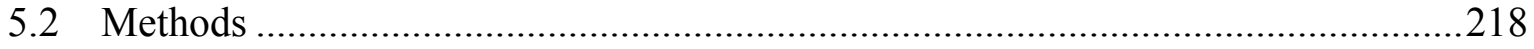

5.2.1 Gene Abundance and Expression ................................................................218

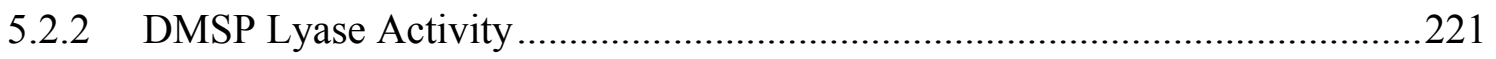

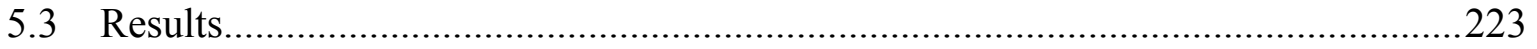

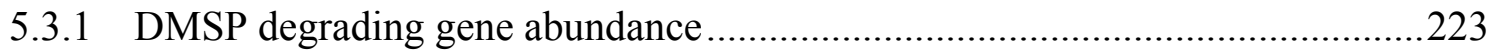

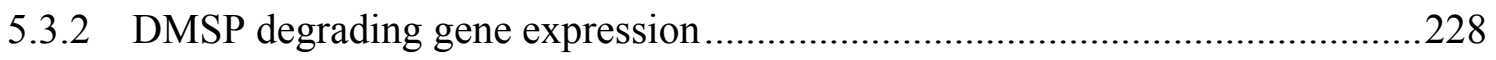

5.3.3 DMS production: potential enzyme activity ……………………………….....233

5.4 Discussion: A mechanistic explanation of the upper ocean sulfur cycle...................234

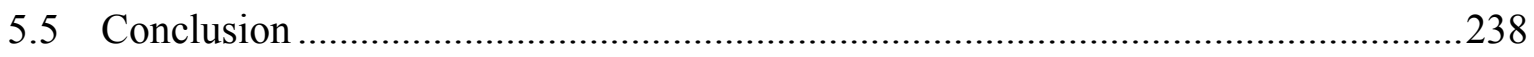

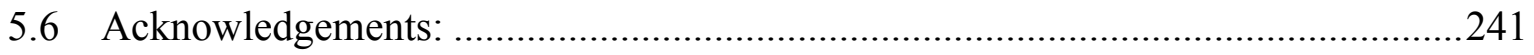

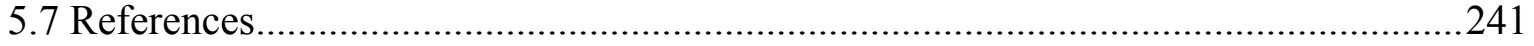




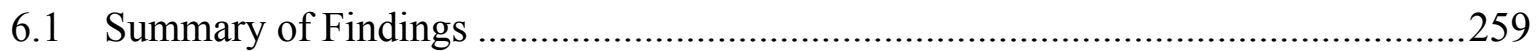

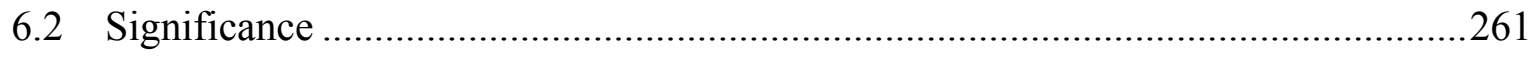

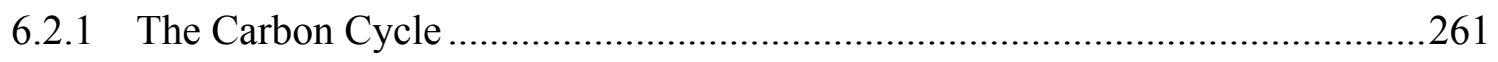

6.2.2 The Sulfur Cycle ...................................................................................265

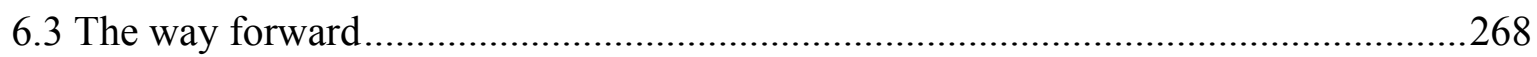

6.3.1 The detection of anthropogenic carbon in the oceans.....................................268

6.3.2 Testing our hypothesis of the upper ocean sulfur cycle..................................269

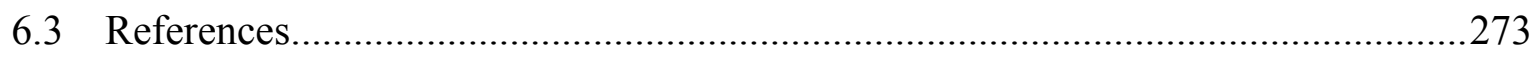

$\begin{array}{ll}\text { Appendix A } & 277\end{array}$

$\begin{array}{ll}\text { Appendix B } & 278\end{array}$

$\begin{array}{lr}\text { Appendix C } & 279\end{array}$

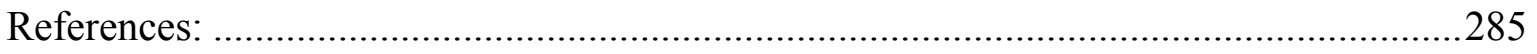

$\begin{array}{ll}\text { Appendix D } & 286\end{array}$

$\begin{array}{ll}\text { Appendix E } & 287\end{array}$

$\begin{array}{ll}\text { Appendix F } & 288\end{array}$

$\begin{array}{ll}\text { Appendix G } & 290\end{array}$

$\begin{array}{ll}\text { Appendix H } & 292\end{array}$

$\begin{array}{ll}\text { Appendix I } & 293\end{array}$

$\begin{array}{ll}\text { Appendix J } & 294\end{array}$

$\begin{array}{lr}\text { Appendix K } & 295\end{array}$

$\begin{array}{ll}\text { Appendix L } & 296\end{array}$

$\begin{array}{ll}\text { Appendix M } & 298\end{array}$ 


\section{List of Tables}

Table 2.1 The mean, mode and maximum of model DIC RMS variability $(1 \sigma)$ in $\mu \mathrm{mol} / \mathrm{kg}$ for model DIC output and the $\Delta \mathrm{C}^{*}, \mathrm{MLR}$, and eMLR techniques.

Table 2.2 The mean, mode, and maximum of the predicted model $\Delta C_{\text {anthro }}$ in $\mu \mathrm{mol} / \mathrm{kg}$ and the $\Delta C_{\text {anthro }}$ estimates in $\mu \mathrm{mol} / \mathrm{kg}$ calculated using the $\Delta C^{*}$, $\Delta C_{P O 4}^{*}$, MLR, and eMLR techniques.

Table 2.3 The $r^{2}$ values, the root mean squared error (RMSE) in $\mu \mathrm{mol} / \mathrm{kg}$, the MLR parameters and $1 \sigma$ errors.

Table 3.1 The relationship between the wintertime NAO index and changes in the Eighteen Degree Water (EDW) and Subpolar Mode Water (SPMW) outcrops and isopycnal surfaces.

Table 4.1 Dates for BATS 2008 cruises.

Table 4.2 Monthly averages of volume of seawater filtered in liters for RNA and DNA samples.

Table 4.3 Monthly statistics for the bacterial (upper table) and phytoplankton (lower table) DMSP lyase potential enzyme activity (DLA) assay.

Table 4.4 Impact of polycarbonate filters on observed DMS concentrations.

Table 5.1 The average individual efficiencies for qPCR samples.

Table 5.2 The efficiency, standard curve $\mathrm{R}^{2}$ values, and fractional error for $\mathrm{qPCR}$ samples. 


\section{List of Figures}

Figure 2.1 Time-series of CSM1.4 model output along the A16 transect.

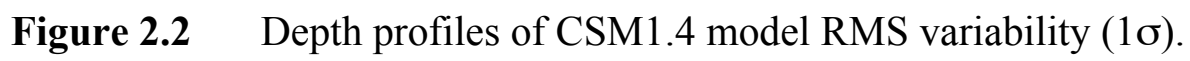

Figure 2.3 Depth profiles of 'snap-shot' change in DIC and the change in AOU.

Figure 2.4 Depth profiles of $\Delta C_{\text {anthro }}^{\text {predice }}$ and $\Delta C^{*}$, MLR, and eMLR estimates of $\Delta \mathrm{C}_{\text {anthro. }}$.

Figure 2.5 Correlation between model $\left(\Delta C_{\text {anthro }}^{\text {predicted }}-\Delta C_{\text {anthro }}^{C^{*}}\right)$ and $\triangle A O U$

Figure 2.6 Depth profiles of MLR $\Delta C_{\text {anthro }}$ and the model MLR residuals

Figure 2.7 $\Delta C_{\text {anthro }}$ inventory calculated using the $\Delta C^{*}$, MLR, and eMLR techniques.

Figure 2.8 Spatial maps of DIC column inventory RMS variability $(1 \sigma)$

Figure 2.9 Spatial maps of of $\Delta C_{\text {anthro }}^{\text {predicted }}$ and $\Delta C^{*}$, MLR, and eMLR estimates of $\Delta \mathrm{C}_{\text {anthro. }}$.

Figure 2.10 Correlation timescales for CSM1.4 model output.

Figure 3.1 Comparison between model and observational $C_{\text {anthro }}$ estimates

Figure 3.2 Change in $C_{\text {anthro }}$ inventory with time

Figure 3.3 Sensitivity of isopycnal band $C_{a n t h r o}$ inventories to variable physics

Figure 3.4 Wintertime outcrop for Eighteen Degree Water and Subpolar Mode Water

Figure 3.5 Impact of variable physics on the Eighteen Degree Water formation region and $C_{\text {anthro }} \mathrm{CO}_{2}$ uptake.

Figure 3.6 Impact of transport on the variability of $C_{\text {anthro }}$ inventory $\left(\mathrm{mol} / \mathrm{m}^{2}\right)$ along the $\sigma_{26.5}$ isopycnal surface.

Figure 3.7 Driving factors for changes in the subtropical gyre $I_{\text {anthro }}$.

Figure 3.8 Impact of the NAO on subpolar mixed layer depths and carbon fluxes.

Figure 3.9 The relationship between anthropogenic $\mathrm{CO}_{2}$ flux and mean mixed layer depth (MLD) for the subpolar gyre.

Figure 3.10 Wintertime $\mathrm{CO}_{2}$ flux onto subpolar mode water isopycnal surfaces $\left(\sigma_{27.3-}\right.$ 27.7).

Figure 3.11 Driving factors for changes in subpolar $I_{\text {anthro }}^{\text {Aphyics. }}$.

Figure 3.12 Water mass transformation in the subpolar gyre. 
Figure 3.13 Relationship between total and anthropogenic carbon.

Figure 3.14 Relationship between NAO wintertime index and maximum MLD and $\Delta I_{\text {anthro }}^{\Delta \text { physics }}$.

Figure 4.1 Upper ocean DMS and DMSP cycle.

Figure 4.2 Bacterially mediated DMSP degradation pathways.

Figure 4.3 Change in DMSPd in DLA assays.

Figure 4.4 Temperature dependence of bacterial DLA and abiotic DMSP degradation.

Figure 4.5 Temperature dependence of bacterial DLA in the field.

Figure 4.6 The impact of 'on-deck waiting time' on DLA rates.

Figure 4.7 Plexiglas RNA extraction hood with quasi-laminar flow HEPA filtered air.

Figure 5.1 Seasonal variability in the upper ocean sulfur cycle at BATS.

Figure 5.2 The relationship between particulate DMSP (DMSPp) and dissolved DMSP (DMPSd).

Figure 5.3 Fraction of cells with DMSP degrading genes.

Figure 5.4 The relationship between DMSP degrading genes at BATS.

Figure 5.5 The abundance of DMSP degrading genes at BATS

Figure 5.6 The expression of DMSP degrading genes at BATS.

Figure 5.7 Fraction of expressed genes.

Figure 5.8 Relationship of DMSP degradation gene expression to DMSP and bacterial dynamics.

Figure 5.9 Bacterial and Phytoplankton DMSP lyase potential enzyme activity.

Figure 5.10 DMS production at 20m for February-November 2008 


\section{Chapter 1}

\section{Introduction}

"Human beings are now carrying out a large scale geophysical experiment of a kind that could not have happened in the past nor be reproduced in the future."

- Roger Revelle and Hans Suess [1957]

\subsection{MOTIVATION}

Over the past century, mankind has unintentionally been conducting a global climate sensitivity experiment. The release of $\sim 330 \mathrm{Pg}$ of anthropogenic derived carbon since the industrial revolution (1850-2006) has resulted in exponentially increasing atmospheric carbon dioxide concentrations [Canadell et al., 2007]. As a potent greenhouse gas, the accumulation of $\mathrm{CO}_{2}$ in the atmosphere alters the global radiative balance. The predicted increase of atmospheric $\mathrm{CO}_{2}$ over the next century is projected to 
significantly increase surface temperatures, resulting in shifts in regional and global climates [Hansen et al., 2006; IPCC, 2001]. This forcing will most likely result in substantial changes to the ocean ecosystem including increased sea surface temperatures, increased vertical stratification, and decreased nutrient concentrations [e.g. P. W. Boyd and Doney, 2002; Sarmiento et al., 2004]. In addition, currently 30\% of anthropogenic carbon emissions are sequestered in the oceans, with roughly half of the emissions remaining in the atmosphere and the remainder being sequestered in the terrestrial biosphere [Canadell et al., 2007; Sabine et al., 2004]. While the uptake of $\mathrm{CO}_{2}$ by the oceans dampens the atmospheric $\mathrm{CO}_{2}$ increase and resulting rise in temperature, increasing ocean dissolved inorganic carbon (DIC) concentrations is projected to significantly alter the $\mathrm{pH}$ of the oceans [Orr et al., 2005]. Ocean acidification has already been observed with surface $\mathrm{pH}$ values $0.1 \mathrm{pH}$ units lower than in pre-industrial times [Fabry et al., 2008]. However, the greater impact of changes in ocean carbonate system, beyond reducing rates of calcification in calcifying organisms, is largely unknown [Fabry et al., 2008 and references therein].

The magnitude of climate induced changes on ocean physics and the impact of these changes on ocean biology will depend to a large part on feedback loops. Positive feedback loops occur when climate induced changes result in more rapid climate change. Conversely, negative feedback loops occur when climate induced changes result in slowing of global climate change. Two oceanic biogeochemical cycles have the potential to directly mediate global climate through ocean-atmosphere feedback loops: the carbon cycle and the sulfur cycle. In order to understand the potential feedbacks of carbon and 
sulfur cycles on climate, it is important to first have an understanding of the mechanisms driving these two biogeochemical cycles.

\subsection{THE CARBON CYCLE}

The ocean carbon cycle is integral to understanding and predicting atmospheric $\mathrm{CO}_{2}$ concentrations. The oceans remove carbon dioxide from the atmosphere via two pathways: the physical solubility pump and the biological carbon pump [Volk and Hoffert, 1985]. The physical pump consists of wind-driven circulation and water mass formation. These physical processes remove $\mathrm{CO}_{2}$ from the atmosphere via air-sea gas exchange and sequester it in the ocean interior through seasonal ventilation of the thermocline, and water mass formation and convergence. The biological pump transfers carbon from the surface ocean into the ocean interior through the export of organic matter from the surface into the deep ocean where it can be remineralized back to $\mathrm{CO}_{2}$. To date, the majority of anthropogenic carbon sequestration in the oceans has been the result of physical processes [e.g. Keeling and Peng, 1995]. In particular, wind-driven air-sea gas exchange has yielded high anthropogenic carbon $\left(C_{\text {anthro }}\right)$ inventories in surface waters [Sabine et al., 2004]. The formation of deep and intermediate waters at high latitudes

also act to sequester a significant amount of $C_{\text {anthro }}$ in the ocean on time scales ranging from decades to centuries [Wallace, 2001]. Given the importance of the oceans as a sink for anthropogenic carbon, changes in either the solubility or biological pumps could significantly impact future atmospheric $\mathrm{CO}_{2}$ concentrations. 


\subsubsection{Carbon Cycle feed backs}

Two primary carbon cycle feedback loops have been proposed: 1) a decrease in the solubility pump due to increased surface water stratification (positive feedback), and 2) changes in the biological pump due to biogeochemically driven changes in carbon fixation. Physical changes are driven by shifts in circulation and increased stratification caused by global temperature rise. These changes will most significantly impact polar regions where warming induced stratification, coupled with surface water freshening, may result in decreased water mass formation and subsequently decreased $\mathrm{CO}_{2}$ uptake [e.g. Sarmiento et al., 1998; Thorpe et al., 2001]. However, modeling work by Russell and co-authors [e.g. Russell et al., 2006] for the Southern Ocean suggests that the opposite hypothesis may also occur. They propose that the predicted poleward intensification of Southern Ocean westerly winds caused by warming climates will decrease stratification by increasing upwelling. This increased ventilation would lead to an enhanced net sink of carbon in the Southern Ocean (negative feedback). Opposing feedbacks to climate changes make it difficult to determine the net impact of these changes on the future of the ocean carbon sink. Therefore, a mechanistic understanding of the processes driving changes in the physical carbon pump is needed in order to accurately predict future changes in the ocean carbon sink.

Variations in global climate will also impact ocean ecosystems thereby impacting the biological carbon pump. Warming induced stratification will reduce upwelling and thus the supply of nutrients to the surface ocean [Karl, 2002]. While decreased surface 
nutrient concentrations has the potential to decrease primary production and carbon fixation (positive feedback), this change may be offset by a number of other biogeochemically driven shifts in ecosystem dynamics that may increase carbon fixation (negative feedback). Boyd and Doney [2003] provide a review of potential changes in the biological carbon pump that could affect carbon storage. For example, elevated $\mathrm{CO}_{2}$ levels may increase phytoplankton growth rates (carbon fertilization), cause shifts in species composition, and impact nutrient uptake stoicheometric ratios. Shifts in species composition may in turn alter carbon export to the deep ocean, rates of organic matter remineralization, and the production of the climatically relevant trace gas dimethylsulfide (see discussion below). Increased iron supply through dust deposition may increase primary production particularly in High Nutrient Low Chlorophyll regions. Finally, decreased fixed nitrogen in surface waters resulting from the predicted increased stratification and increased iron from dust deposition may yield increased rates of nitrogen fixation. Due to the complexity of the ocean ecosystem and potential for interplay among various feedbacks, the absolute magnitude and even sign of these impacts remains unclear. Further work is needed to elucidate the mechanisms driving these feedbacks.

While it is extremely difficult to quantify these feedbacks in the field, numerical models can provide insight into how the ocean system may react to changes in climate forcings. Specifically, the magnitude and signs of these feedbacks and interactions between physical and biogeochemical changes are being investigated using coupled carbon climate models. Fung et al. [2005] suggest that reduced $\mathrm{CO}_{2}$ uptake caused by 
changes in the physical pump are mitigated by increased uptake by the biological pump with a net positive feedback between the global carbon system and climate. Similarly, a modeling study by Sarmiento et al. [1998] found evidence of a negative biological pump feedback in the Southern Ocean. However, the uncertainties in both the physical and biological responses to climate change are significant. An improved mechanistic understanding of anthropogenic carbon uptake and storage is needed in order to constrain these feedbacks and accurately predict future atmospheric $\mathrm{CO}_{2}$ and temperature increases. This thesis works towards this goal by studying mechanisms driving interannual variability in the uptake and storage of anthropogenic carbon and the implications of this variability on the detection of $\mathrm{C}_{\text {anthro }}$ using observations.

\subsubsection{Estimates of the ocean carbon sink}

Current estimates of oceanic $C_{\text {anthro }}$ distributions and rates of change are made from hydrographic measurements and numerical model simulations. Direct observations produce 'snap shots' views of the ocean system. Since the 1970's, several global surveys of the ocean carbon system have been conducted including the Geochemical Ocean Section Study (GEOSECS), and the World Ocean Circulation Experiment (WOCE)/Joint Global Ocean Flux Study (JGOFS). Currently, the US and International Climate Variability and Predictability (CLIVAR)/ $\mathrm{CO}_{2}$ program is continuing to monitor changes in ocean carbon by repeating key hydrographic surveys from the WOCE/JGOFS era. The thousands of high precision carbon observations measured during these programs have provided a picture of the magnitude and variability of the ocean carbon sink. However, 
in order to estimate anthropogenic carbon from hydrographic measurements, the relatively small anthropogenic signal, about $5 \%$ of total dissolved inorganic carbon in surface waters in the 1990s [Sabine et al., 2004], must be separated from the background natural dissolved inorganic carbon (DIC). In addition, the anthropogenic signal is further obscured by significant short-term variability in the ocean carbon system.

Several empirical methods have been proposed to assist in the detection and attribution of anthropogenic carbon from hydrographic measurements. Typically, observed DIC fields are corrected for changes in biology and circulation using tracers of these processes, such as changes in apparent oxygen utilization, nutrient concentrations, temperature and salinity. Some approaches (e.g. $\Delta C^{*}$ [Gruber et al., 1996]) make this correction using thermodynamic principles and biogeochemical assumptions, for example considering carbonate thermodynamics and organic matter remineralization stoichiometries. Alternatively, a purely statistical method can be used to remove variability in DIC due to natural changes in circulation and biological respiration and remineralization (e.g. Multiple Linear Regression approach [Brewer et al., 1995; Wallace, 1995], see Chapter 2 for details). Often different empirical techniques for determining $C_{\text {anthro }}$ give significantly different inventory estimates and spatial distributions. However, determining the success or failure of the various methods is difficult as the 'true' anthropogenic signal is unknown. Accurate monitoring of oceanic $C_{\text {anthro }}$ is not only essential for determining the magnitude of the ocean carbon sink, but also for validating models that are used to predict future changes in ocean uptake and atmospheric $\mathrm{CO}_{2}$ concentrations. In this thesis, models and observations are used 
synergistically in order to provide insight into the limitations of the empirical methods and potential biases in our observational based estimates of $C_{\text {anthro }}$ (Chapter 2).

Numerical models provide an invaluable tool for understanding natural variability in the ocean carbon system, providing a context for observations, and elucidating driving mechanisms for observed changes in $C_{\text {anthro }}$ and DIC. The first three dimensional model estimates of the spatial distribution of $\mathrm{C}_{\text {anthro }}$ uptake by the oceans were made by MaierReimer and Hasselmann [1987], Bacastow and Maier-Reimer [1990], and Sarmiento et al. [1992]. The latter uses a primitive equation 3-D global general circulation model with annual mean forcing derived from observations and atmospheric $\mathrm{CO}_{2}$ concentrations prescribed using historical data and observations. These early models provided an initial estimate of the magnitude and spatial distribution of the ocean carbon sink. However, they lacked fundamental components, such as seasonal and interannual variability in model forcing, biological fluxes, and climate feedbacks, which are essential for a more accurate determination of $C_{\text {anthro }}$ storage, spatial distributions, and future projections. The subsequent generations of models included many of these components, for example the inclusion of a biological carbon pump [e.g. Sarmiento et al., 1995], and the inclusion of changes in radiative forcing due to changes in atmospheric $\mathrm{CO}_{2}$ [e.g. Sarmiento et al., 1998]. The current generation of global climate models are fully coupled with ocean, atmosphere, terrestrial and sea-ice modules, seasonal cycles and interannual variability, full ocean carbonate systems, and multiple-component ecosystems [e.g. Fung et al., 2005]. These models can be run either as fully coupled systems allowing for future projections of global carbon and climate system dynamics, or as hindcast simulations that 
provide insight into the driving mechanisms behind observed interannual variability. Hindcast simulations are run using global ocean biogeochemical models forced with atmospheric reanalysis and satellite data products [e.g. Doney et al., 2007]. These models have been used to evaluate the mechanisms behind interannual variability in ocean temperature [e.g. Doney et al., 2007], air-sea $\mathrm{CO}_{2}$ flux [e.g. Doney et al., 2009; Thomas et al., 2008], and pre-industrial carbon concentrations [e.g. Doney et al., 2009]. In this thesis, interannual variability of the ocean carbon system is investigated using both a fully coupled global carbon model and the hindcast simulation of this model. We examine the mechanisms driving variability in anthropogenic carbon in the model and explore the implications of this variability on the detection and attribution of $C_{\text {anthro }}$ from hydrographic observations.

\subsection{THE SULFUR CYCLE}

Dimethylsulfide (DMS), a climatically relevant gas, is produced and cycled in coastal and open ocean ecosystems by the food web and is the predominant source of biogenic sulfur to the atmosphere. Marine emissions of DMS constitute greater than 55\% of the global non-anthropogenic biogenic sulfur flux, and greater than $90 \%$ of the marine biogenic sulfur flux [Andreae, 1990; Kelly and Smith, 1990]. Once ventilated to the atmosphere, DMS is oxidized to sulfate and methane sulfonate aerosols [Shaw, 1983], which act as cloud condensation nuclei. Perturbations in DMS ventilation rates have the potential to alter aerosol abundance, cloud coverage, and cloud properties, which in turn 
affect the atmospheric radiative balance and climate [Charlson et al., 1987]. In 1987, Charlson et al. proposed that marine phytoplankton regulate their environment through the production of DMS. They hypothesized that, in response to radiative or temperature stress, marine phytoplankton increase DMS production. This, in turn, increases ventilation of DMS to the atmosphere, augments regional cloud cover, and ultimately decreases the radiative or temperature stress for the phytoplankton thereby forming a negative feedback loop. The DMS cycle has proved to be significantly more complex than Charlson et al. originally suggested. We now understand that the entire microbial food web is involved in DMS cycling and that bacteria, as well as phytoplankton, are important.

It is believed that phytoplankton produce the primary precursor of DMS, dimethylsulfoniopropionate (DMSP). The production of DMSP is hypothesized to be in response to environmental stresses such as osmotic, oxidative, grazing, or temperature stress. Several studies have shown that phytoplankton only convert a small fraction of their DMSP to DMS [Niki et al., 2000; Stefels and Dijkhuizen, 1996; Wolfe et al., 2002]. The majority of phytoplankton intracellular DMSP is released into the water column via cell senescence, grazing, and viral lysis where it is then rapidly cycled by the bacterial community. Due to non-DMS producing bacterial degradation of DMSP and bacterial DMS consumption, only a small percentage (1-2\%) of DMSP produced by marine phytoplankton is ventilated to the atmosphere as DMS [Bates et al., 1994; Kwint and Kramer, 1996]. While we have come a long way from Charlson et al.'s [1987] initial hypothesis, we still have only a rudimentary understanding of the mechanisms driving 
sulfur cycling dynamics in the surface ocean, in particular bacterial sulfur cycle dynamics.

DMS concentrations in aquatic ecosystems are controlled by phytoplankton taxonomy, productivity and physiological status, bacterial transformations, photochemical oxidation and ventilation. Therefore, changes in the physical and chemical properties of aquatic ecosystems, such as those projected to occur under high $\mathrm{CO}_{2}$ conditions, have the potential to affect DMS production. In particularly, predicted changes in wind stress and radiative flux have the potential to impact community composition, rates of primary production, and biogeochemical cycling. This response to anthropogenic induced changes could either offset or augment global temperature increases. As Charlson et al. [1987] initially proposed, increased DMS ventilation to the atmosphere may act as a negative feedback decreasing global temperatures. However the converse is also possible; decreased DMS may decrease cloud formation and back-scatter of incoming solar radiation, and augment temperature increases. Similar to the carbon cycle, both the sign and magnitude of the potential sulfur cycle feedback is unknown. Previous studies have predicted both scenarios from a $14 \%$ increase in global DMS emissions by 2080 [Gabric et al., 2004] to a $10 \%$ decrease in global DMS emissions by 2100 [Kloster et al., 2007]. The uncertainty in the response of the marine sulfur cycle to anthropogenic activity is due to our limited knowledge of the physical and chemical mechanisms driving DMS production in marine ecosystems. Therefore, current DMS models are limited in their ability to accurately produce reliable predictions of future DMS emissions and how this will ultimately impact the radiative budget. 


\subsection{UNDERSTANDING VARIABILITY}

The oceans are dynamic and complex systems with significant variability on timescales ranging from hours to centuries. This variability is reflected in both the carbon and sulfur cycles. Identifying the driving mechanisms behind these changes provides an improved understanding of the biogeochemical cycle and allows for a more accurate prediction of the impact of climate change. In this thesis, we focus on mechanisms driving seasonal and interannual variability in anthropogenic carbon accumulation and DMS production.

Oceanic carbon and sulfur pools are impacted by chemical, physical and biological processes. Therefore, in order to fully understand these cycles, it is necessary to pursue an interdisciplinary approach. In addition, the use of observations in conjunction with numerical models can both validate the models, which are then used for future climate predictions, and provide a context and mechanistic explanation for the observations. This thesis uses a unique combination of chemical, biological, genomic, and numerical techniques to increase our understanding of the variability in ocean carbon and sulfur cycling.

\subsection{RESEARCH STRATEGY}

Several questions motivated the carbon cycle research presented in this thesis: 1) How does interannual variability in the ocean carbon system impact our ability to observe 
and quantify the uptake of anthropogenic carbon by the oceans? 2) How does interannual variability impact the magnitude of the ocean carbon sink and distribution of $C_{\text {anthro }}$ in the ocean interior? and 3) What are the mechanisms behind the observed variability in ocean $C_{\text {anthro }}$ ? These questions are addressed in Chapters 2 and 3. Specifically, Chapter 2 uses the output of a global coupled climate model as an artificial dataset to test the accuracy of two empirical methods used to calculate anthropogenic carbon from hydrographic observations. This chapter identifies regions where the empirical methods are not able to correct for natural variability in the carbon system, namely high latitude water mass formation regions, and suggests approaches that may minimize errors in anthropogenic carbon estimates. Chapter 3 uses a suite of ocean model simulations to evaluate interannual variability in anthropogenic carbon storage in the North Atlantic. This work focuses on the impact of the North Atlantic Oscillation, the dominant climate mode in the North Atlantic that oscillates between positive and negative phases, on the uptake of anthropogenic $\mathrm{CO}_{2}$ and changes in anthropogenic carbon inventories. The results suggest that increased mode water transformation during positive North Atlantic Oscillation years results in increased storage of anthropogenic carbon. Water mass transformation creates dense water masses through diapycnal mixing and surface water transformations via airsea buoyancy fluxes. In this case, mode waters are formed from high anthropogenic $\mathrm{CO}_{2}$ surface waters. This work implies that much of the anthropogenic carbon found in the ocean interior is from surface waters advected into the water mass formation region rather than from local gas exchange. Therefore, interannual variability in ocean physics, 
specifically wind-driven circulation and heat transfer, significantly impacts both the storage and detection of anthropogenic carbon in the ocean.

Similar to the carbon cycle work presented in Chapters 2 and 3, Chapters 4 and 5 attempt to determine the primary mechanisms driving seasonal variability in the upper ocean sulfur cycle. Specifically, this study focuses on understanding the chemical and physical mechanisms controlling bacterial cycling of DMSP in open ocean, oligotrophic waters. As described briefly above, the majority of DMSP produced by phytoplankton is released into the water column and cycled by the bacterial community. This community degrades DMSP via two pathways, a cleavage pathway which produces DMS and a demethylation pathway which excludes DMS as a product [Cantoni and Anderson, 1956; Kiene and Taylor, 1988]. In addition, bacterial DMS degradation is the primary loss process for DMS below the surface layer [Simo, 2004]. Therefore, the release of DMS to the atmosphere strongly depends on the activity of the bacterioplankton community. A new method was developed to measure the activity of bacterial DMS producing enzymes in field samples (Chapter 4). In addition, a series of sensitivity tests were conducted to optimize the protocols for the Sargasso Sea and to understand the limitations of the methods (Chapter 4).

Seasonal variations in the two bacterial DMSP degradation pathways were quantified in a 10-month time-series at the Bermuda Atlantic Time-series Study site (Chapter 5). During monthly cruises, depth profiles of the DMSP demethylation pathway were quantified through the expression and abundance of 5 subclades of the bacterial DMSP demethylation gene $d m d A$. The DMSP cleavage pathway was quantified 
both through gene expression and abundance analyses ( $d d d P$ gene) and through the bacterial DMSP cleavage potential enzyme activity assay. In addition, monthly phytoplankton DMS production was measured using the phytoplankton DMSP lyase potential enzyme assay. Based on this work, a modified conceptual model for the open ocean, oligotrophic sulfur cycle is proposed. Bacteria are shown to play a significant role in DMS and DMSP cycling with substantial bacterial DMS production in the upper water column, particularly in the late summer and early fall (Chapter 5). In addition, DMSP degradation is shown to be carried out by a diverse group of bacteria and the potential for bacterial subclade niche differentiation is suggested (Chapter 5). Finally, the importance of UV radiative stress in oligotrophic organic sulfur cycling by both phytoplankton and bacteria is suggested (Chapter 5). 


\subsection{REFERENCES}

Andreae, M. O. (1990), Ocean-Atmosphere Interactions in the Global Biogeochemical Sulfur Cycle, Marine Chemistry, 30(1-3), 1-29.

Bacastow, R. B., and E. Maier-Reimer (1990), Ocean-circulation model of the carbon cyle, Climate Dynamics, 4, 95-125.

Bates, T. S., R. P. Kiene, G. V. Wolfe, P. A. Matrai, F. P. Chavez, K. R. Buck, B. W. Blomquist, and R. L. Cuhel (1994), The Cycling of Sulfur in Surface Seawater of the Northeast Pacific, Journal of Geophysical Research-Oceans, 99(C4), 7835-7843.

Boyd, P. W., and S. C. Doney (2002), Modelling regional responses by marine pelagic ecosystems to global climate change, Geophys. Res. Lett., 29(16).

Boyd, P. W., and S. C. Doney (Eds.) (2003), The Impact of Climate Change and Feedback Processes on the Ocean Carbon Cycle, Springer-Verlag, New York.

Brewer, P. G., D. M. Glover, C. Goyet, and D. K. Shafer (1995), The pH of the NorthAtlantic Ocean - Improvements to the Global-Model for Sound-Absorption in Seawater, Journal of Geophysical Research-Oceans, 100(C5), 8761-8776.

Canadell, J. G., C. Le Quere, M. R. Raupach, C. B. Field, E. T. Buitenhuis, P. Ciais, T. J. Conway, N. P. Gillett, R. A. Houghton, and G. Marland (2007), Contributions to accelerating atmospheric $\mathrm{CO} 2$ growth from economic activity, carbon intensity, and efficiency of natural sinks, Proceedings of the National Academy of Sciences of the United States of America, 104(47), 18866-18870.

Cantoni, G. L., and D. G. Anderson (1956), Enzymatic cleavage of dimethylpropiothetin by polysiphonia lansoa, Journal of Biological Chemistry, 222, 171-177.

Charlson, R. J., J. E. Lovelock, M. O. Andreae, and S. G. Warren (1987), Oceanic Phytoplankton, Atmospheric Sulfur, Cloud Albedo and Climate, Nature, 326(6114), 655661.

Doney, S. C., S. Yeager, G. Danabasoglu, W. G. Large, and J. C. McWilliams (2007), Mechanisms governing interannual variability of upper-ocean temperature in a global ocean hindcast simulation, Journal of Physical Oceanography, 37(7), 1918-1938. 
Doney, S. C., I. Lima, R. A. Feely, D. M. Glover, K. Lindsay, N. Mahowald, J. K. Moore, and R. Wanninkhof (2009), Mechanisms governing interannual variability in upper-ocean inorganic carbon system and air-sea CO2 fluxes: Physical climate and atmospheric dust, Deep-Sea Research Part Ii-Topical Studies in Oceanography, 56(810), 640-655.

Fabry, V. J., B. A. Seibel, R. A. Feely, and J. C. Orr (2008), Impacts of ocean acidification on marine fauna and ecosystem processes, ICES Journal of Marine Sciences, 65(3), 414-432.

Fung, I. Y., S. C. Doney, K. Lindsay, and J. John (2005), Evolution of carbon sinks in a changing climate, Proceedings of the National Academy of Sciences of the United States of America, 102(32), 11201-11206.

Gabric, A. J., R. Simo, R. A. Cropp, A. C. Hirst, and J. Dachs (2004), Modeling estimates of the global emission of dimethylsulfide under enhanced greenhouse conditions, Global Biogeochemical Cycles, 18(2).

Gruber, N., J. L. Sarmiento, and T. F. Stocker (1996), An improved method for detecting anthropogenic $\mathrm{CO}_{2}$ in the oceans, Global Biogeochemical Cycles, 10(4), 809-837.

Hansen, J., M. Sato, R. Ruedy, K. Lo, D. W. Lea, and M. Medina-Elizade (2006), Global temperature change, Proceedings of the National Academy of Sciences of the United States of America, 103(39), 14288-14293.

IPCC (2001), Climate Change 2001: The Scientific Basis. Contribution of Working Group I to the Third Assessment Report of the Intergovernmental Panel on Climate Change 881 pp., Cambridge University Press, Cambridge, United Kingdom and New York, NY, USA.

Karl, D. M. (2002), Nutrient dynamics in the deep blue sea, Trends Microbiol., 10(9), 410-418.

Keeling, R. F., and T.-H. Peng (1995), Transport of heat, CO2, and O2 by the Atlantic's thermohaline circulation, Phil. Trans. R. Soc. Lond. B, 348(133-142).

Kelly, D. P., and N. A. Smith (1990), Organic sulfur compounds in the environmentbiogeochemistry, microbiology and ecological aspects., Advances in Microbial Ecology, $11,345-385$. 
Kiene, R. P., and B. F. Taylor (1988), Demethylation of Dimethylsulfoniopropionate and Production of Thiols in Anoxic Marine-Sediments, Applied and Environmental Microbiology, 54(9), 2208-2212.

Kloster, S., K. D. Six, J. Feichter, E. Maier-Reimer, E. Roeckner, P. Wetzel, P. Stier, and M. Esch (2007), Response of dimethylsulfide (DMS) in the ocean and atmosphere to global warming, Journal of Geophysical Research-Biogeosciences, 112(G3).

Kwint, R. L. J., and K. J. M. Kramer (1996), Annual cycle of the production and fate of DMS and DMSP in a marine coastal system, Marine Ecology-Progress Series, 134(1-3), 217-224.

Maier-Reimer, E., and K. Hasselmann (1987), Transport and storage of CO2 in the ocean- an inorganic ocean-circulation cycle model, Climate Dynamics, 2, 63-90.

Niki, T., M. Kunugi, and A. Otsuki (2000), DMSP-lyase activity in five marine phytoplankton species: its potential importance in DMS production, Marine Biology, 136(5), 759-764.

Orr, J. C., et al. (2005), Anthropogenic ocean acidification over the twenty-first century and its impact on calcifying organisms, Nature, 437(7059), 681-686.

Revelle, R., and H. E. Suess (1957), Carbon dioxide exchange between atmosphere and ocean and the question of an increase of atmospheric $\mathrm{CO} 2$ during the past decades, Tellus, 9(1), 18-27.

Russell, J. L., K. W. Dixon, A. Gnanadesikan, R. J. Stouffer, and J. R. Toggweiler (2006), The Southern Hemisphere westerlies in a warming world: Propping open the door to the deep ocean, Journal of Climate, 19(24), 6382-6390.

Sabine, C. L., et al. (2004), The oceanic sink for anthropogenic $\mathrm{CO}_{2}$, Science, 305(5682), 367-371.

Sarmiento, J. L., J. C. Orr, and U. Siegenthaler (1992), A Perturbation Simulation of Co2 Uptake in an Ocean General-Circulation Model, Journal of Geophysical ResearchOceans, 97(C3), 3621-3645.

Sarmiento, J. L., R. Murnane, and C. Lequere (1995), Air-Sea Co2 Transfer and the Carbon Budget of the North-Atlantic, Philosophical Transactions of the Royal Society of London Series B-Biological Sciences, 348(1324), 211-219. 
Sarmiento, J. L., T. M. C. Hughes, R. J. Stouffer, and S. Manabe (1998), Simulated response of the ocean carbon cycle to anthropogenic climate warming, Nature, 393(6682), 245-249.

Sarmiento, J. L., et al. (2004), Response of ocean ecosystems to climate warming, Global Biogeochemical Cycles, 18(3).

Shaw, G. E. (1983), Bio-Controlled Thermostasis Involving the Sulfur Cycle, Climatic Change, 5(3), 297-303.

Simo, R. (2004), From cells to globe: approaching the dynamics of DMS(P) in the ocean at multiple scales, Canadian Journal of Fisheries and Aquatic Sciences, 61(5), 673-684.

Stefels, J., and L. Dijkhuizen (1996), Characteristics of DMSP-lyase in Phaeocystis sp (Prymnesiophyceae), Marine Ecology-Progress Series, 131(1-3), 307-313.

Thomas, H., A. E. F. Prowe, I. D. Lima, S. C. Doney, R. Wanninkhof, R. J. Greatbatch, U. Schuster, and A. Corbiere (2008), Changes in the North Atlantic Oscillation influence $\mathrm{CO} 2$ uptake in the North Atlantic over the past 2 decades, Global Biogeochemical Cycles, 22(4).

Thorpe, R. B., J. M. Gregory, T. C. Johns, R. A. Wood, and J. F. B. Mitchell (2001), Mechanisms determining the Atlantic thermohaline circulation response to greenhouse gas forcing in a non-flux-adjusted coupled climate model, Journal of Climate, 14(14), 3102-3116.

Volk, T., and M. I. Hoffert (1985), Ocean carbon pumps: analysis of relative strengths and efficiencies in ocean-driven atmospheric $\mathrm{CO} 2$ changes, in The carbon cycle and atmospheric CO2: natural variations archean to present, edited by E. T. Sundquist and W. S. Broecker, pp. 99-110.

Wallace, D. (1995), Monitoring global ocean carbon inventoriesRep., 54 pp, Ocean Observing System Development Panel, Texas A\&M University, College Station, TX.

Wallace, D. (2001), Storage and transport of excess $\mathrm{CO}_{2}$ in the ocean: The JGOFS/WOCE global $\mathrm{CO}_{2}$ survey, in Ocean Circulation and Climate, edited by $\mathrm{G}$. Siedler, J. Church and J. Gould, pp. 489-521, Academic Press, San Diego, CA.

Wolfe, G. V., S. L. Strom, J. L. Holmes, T. Radzio, and M. B. Olson (2002), Dimethylsulfoniopropionate cleavage by marine phytoplankton in response to mechanical, chemical, or dark stress, Journal of Phycology, 38(5), 948-960. 


\section{Chapter 2}

\section{The Impact of Ocean Carbon System Variability on the Detection of Temporal Increases in Anthropogenic $\mathrm{CO}_{2}$}

An edited version of this paper was published by AGU. This work is reprinted here with permission of the American Geophysical Union.

Levine, N. M., S. C. Doney, R. Wanninkhof, K. Lindsay, and I. Y. Fung (2008), Impact of ocean carbon system variability on the detection of temporal increases in anthropogenic CO2, J Geophys. Res., 113, C03019, doi:10.1029/2007JC004153. Copyright (2008) American Geophysical Union. 


\begin{abstract}
Estimates of temporal trends in oceanic anthropogenic $\mathrm{CO}_{2}$ rely on the ability of empirical methods to remove the large natural variability of the ocean carbon system. A coupled carbon-climate model is used to evaluate these empirical methods. Both the $\Delta C^{*}$ and MLR techniques reproduce the predicted increase in dissolved inorganic carbon for the majority of the ocean and have similar average percent errors for decadal differences (24.1\% and $25.5 \%$ respectively). However, this study identifies several regions where these methods may introduce errors. Of particular note are mode and deep water formation regions, where changes in air-sea disequilibrium and structure in the MLR residuals introduce errors. These results have significant implications for decadal repeat hydrography programs, indicating the need for sub-annual sampling in certain regions of the oceans in order to better constrain the natural variability in the system and robustly estimate the intrusion of anthropogenic $\mathrm{CO}_{2}$.
\end{abstract}

\title{
2.1 INTRODUCTION
}

Since the start of the industrial revolution, anthropogenic activity, such as fossil fuel combustion, has resulted in the emission of large quantities of carbon dioxide $\left(\mathrm{CO}_{2}\right)$ into the atmosphere. The resulting increase of atmospheric $\mathrm{CO}_{2}$ over the past several centuries has been well documented from high-resolution ice cores [e.g. Etheridge et al., 1996] and, starting in 1957, direct measurements [e.g. Keeling and Whorf, 1994; Keeling et al., 1976]. As $\mathrm{CO}_{2}$ is a potent greenhouse gas, increased atmospheric concentrations 
are projected to increase surface temperatures, resulting in shifts in regional and global climates [e.g. Hansen et al., 2006; IPCC, 2001]. Consequently, there is great interest in quantifying the current and future rates of increase of atmospheric $\mathrm{CO}_{2}$ and predicting the effect of these increased concentrations on the global climate [e.g. Dilling et al., 2003].

Not all anthropogenic $\mathrm{CO}_{2}$ remains in the atmosphere. Current estimates are that the oceans and terrestrial biosphere have each removed $\sim 30 \%$ of anthropogenic $\mathrm{CO}_{2}$ emissions over the past 20 years [IPCC, 2001; Sabine et al., 2004b]. Due to large uncertainties on these estimates, there are ongoing efforts to better quantify the magnitude of these two sinks using a combination of field programs, empirical methods, and numerical models. For the oceans, a major focus is on directly measuring the temporal change in the oceanic dissolved inorganic carbon (DIC) inventory through timeseries and repeat hydrographic sections [Peng et al., 1998; Wallace, 1995; 2001]. The U.S. and international CLIVAR/ $\mathrm{CO}_{2}$ programs (http://ushydro.ucsd.edu; http://ioc.unesco.org/ioccp), for example, are monitoring the oceans' response to anthropogenic $\mathrm{CO}_{2}$ and climate change through reoccupation on approximately a decadal time-scale of key sections from the 1990's WOCE/JGOFS Global $\mathrm{CO}_{2}$ Survey.

The ocean carbon system exhibits significant natural climate variability on subannual to decadal and longer time scales. This natural variability complicates efforts to constrain oceanic anthropogenic $\mathrm{CO}_{2}$ uptake via direct measurements of DIC temporal changes. For example, an estimate of the increase in DIC due to anthropogenic $\mathrm{CO}_{2}$, $\Delta C_{a n t h r o}$, can be computed by differencing observed DIC concentrations at two sampling times: 


$$
\Delta C_{\text {anthro }}=C_{o b s}\left(t_{1}\right)-C_{o b s}\left(t_{0}\right)
$$

However, this estimate will alias vertical and lateral heave of isopycnal surfaces associated with mesoscale eddies and frontal oscillations [Haine and Gray, 2001; Peacock et al., 2005] as well as shifts in water masses and water mass properties associated with interannual climate modes such as the El Nino Southern Oscillation [Feely et al., 1999; Le Quere et al., 2003]. This is particularly a problem for field programs such as CLIVAR/ $/ \mathrm{CO}_{2}$, which sample on limited spatial and temporal time scales and so greatly under-sample the natural variability of the ocean carbon system. However, these programs are currently one of the only ways of acquiring basin-scale, full-depth ocean coverage.

Two broad categories of methods have been proposed to correct observed DIC fields for natural variability in biology and circulation in order to detect secular trends in anthropogenic $\mathrm{CO}_{2}$ storage. The first approach estimates total anthropogenic $\mathrm{CO}_{2}$ $\left(C_{\text {anthro }}\right)$, defined as the DIC concentration difference between current and pre-industrial conditions. Empirical methods for estimating $C_{a n t h r o}$, first introduced by Brewer [1978] and Chen and Millero [1979], take the general form:

$$
C_{\text {anthro }}=C_{o b s}-C_{e q}-C_{b i o}-C_{d i s s}
$$

where $C_{o b s}$ is the observed DIC, $C_{e q}$ is the equilibrium DIC concentration for a preindustrial atmosphere $(280 \mathrm{ppm}), C_{b i o}$ is the change in DIC due to remineralization of organic matter, and $C_{d i s s}$ is the change in DIC due to the dissolution of calcium carbonate. Gruber et al. [1996] modified equation 2 by adding a term, $C_{\text {diseq, }}$, to account for the $\mathrm{CO}_{2}$ air-sea disequilibrium experienced by a water parcel when it was last at the surface: 


$$
C_{\text {anthro }}^{C^{*}}=\Delta C^{*}-C_{\text {diseq }}
$$

where $\Delta \mathrm{C}^{*}$ equals $\mathrm{C}_{\text {anthro }}$ in equation 2. This technique (termed the $\Delta C^{*}$ method) corrects DIC for changes in rates of remineralization and dissolution using other tracers for these processes, such as apparent oxygen utilization (AOU) and the change in alkalinity. This requires the assumption that changes in $\mathrm{AOU}$ and alkalinity can be converted to changes in DIC using fixed ratios. In addition, the $\Delta C^{*}$ method does not account for changes in DIC resulting from isopycnal heave and so is typically be applied along isopycnal surfaces to avoid biases in the estimate of $C_{\text {anthro }}$ [Gruber et al., 1996].

The $\Delta C^{*}$ method is commonly used for estimating $C_{\text {anthro }}$ albeit with subtle difference in application [Coatanoan et al., 2001; Gruber, 1998; Lee et al., 2003; Lo Monaco et al., 2005; Sabine and Feely, 2001; Sabine et al., 2004a; Sabine et al., 1999; Sabine et al., 2002; Wanninkhof et al., 1999]. Several other empirical methods have been proposed for estimating total anthropogenic $\mathrm{CO}_{2}$, including the TrOCA approach [Touratier and Goyet, 2004a; b; Touratier et al., 2005] and the MIX approach [Goyet et al., 1999]. Estimates of total anthropogenic $\mathrm{CO}_{2}$ can also be used to estimate the temporal change of $\mathrm{C}_{\text {anthro }}, \Delta C_{\text {anthro }}$, by differencing $C_{\text {anthro }}$ from two sampling times; for example [Peng et al., 1998; Sabine et al., 2004a]:

$$
\Delta C_{\text {anthro }}^{C^{*}}=C_{\text {anthro }}^{C^{*}}\left(t_{1}\right)-C_{\text {anthro }}^{C^{*}}\left(t_{0}\right)
$$

The second approach for correcting observed DIC fields in order to estimate the temporal change in anthropogenic carbon, $\Delta C_{\text {anthro }}$, utilizes multiple linear regression (MLR) analysis [Friis et al., 2005; Goyet and Davis, 1997; Peng, 2005; Peng et al., 2003; Sabine et al., 2004a; Sabine et al., 1999; Wanninkhof et al., 2006a]. This technique, 
introduced by Brewer et al. [1995] and Wallace [1995], is a purely statistical method for removing variability in DIC due to natural changes in circulation and biological respiration and remineralization. The MLR method fits observed DIC as a function of physical (temperature, salinity) and biogeochemical (oxygen, phosphate, nitrate, silicate) properties. $\Delta C_{\text {anthro }}$ is then estimated as the residual between the observed DIC and an MLR calculated DIC, which is representative of some earlier time (see details is section 2.3.2):

$$
\Delta C_{\text {anthro }}^{M L R}=C_{o b s}\left(t_{1}\right)-C^{M L R}\left(t_{0}\right)
$$

The basic assumption is that temporal variability in DIC due to natural processes will follow the linear spatial relationships derived using the MLR, while DIC changes due to anthropogenic activity will not. In theory, the MLR should remove the majority of the DIC variability caused by heaving of isopycnal surfaces or shifts in fronts between water masses.

As an alternative to the above mentioned empirical techniques, tracer-based proxy methods are often used to estimate the temporal evolution of anthropogenic $\mathrm{CO}_{2}$ in the ocean. These approaches use tracers, such as $\delta^{13} \mathrm{C}$ and chlorofluorocarbons, as proxies for anthropogenic $\mathrm{CO}_{2}$ [e.g. McNeil et al., 2003; Quay et al., 2003; Wallace, 1995; Waugh et al., 2006]. Often different empirical techniques and tracer approaches give significantly different inventory estimates and spatial distributions of anthropogenic carbon. Several studies have compared $C_{\text {anthro }}$ estimates made by these various techniques [Lo Monaco et al., 2005; Peng, 2005; Peng et al., 2003; Sabine et al., 1999; Wanninkhof et al., 1999]. However, determining the success or failure of these methods is difficult as the 'true' 
anthropogenic signal is unknown. Several studies [e.g. Matsumoto and Gruber, 2005; Waugh et al., 2006] have addressed this problem by using the output of a global climate model as a synthetic dataset to compare empirical based estimates of $C_{a n t h r o}$ to the "true" anthropogenic signal in the model. Matsumoto and Gruber [2005] use this approach to conclude that the largest error in the $\Delta C^{*}$ estimate of $C_{\text {anthro }}$ is due to the uncertainty in the air-sea disequilibrium term.

The objective of this study is to evaluate our ability to accurately estimate the increase of oceanic anthropogenic $\mathrm{CO}_{2}$ over time, $\Delta C_{a n t h r o}$. To do this, we use the output of a coupled-carbon-climate model as an artificial dataset to which we apply commonly used empirical methods for estimating $\Delta C_{\text {anthro }}$; our approach is similar to that of Matsumoto and Gruber [2005] but with an emphasis on temporal changes. To replicate the sampling schemes of repeat hydrography programs, which are reoccupying ocean sections on a $\sim 10$ year time scale, we sample model output for two months 10 years apart. We use this synthetic dataset to determine where these methods may succeed and may fail in the context of ocean carbon variability and the current CLIVAR/CO2 Repeat Hydrography Program.

This study compares the two most widely used techniques: $\Delta C^{*}$ and MLR. We find that both methods have similar average percent errors and RMS errors, and do a reasonable job reproducing the temporal trends of the predicted anthropogenic signal. However, the $\Delta C^{*}$ method is unable to remove some of the natural variability in the ocean carbon cycle, particularly in high latitude deep convection regions, resulting in estimates of $\Delta C_{\text {anthro }}$ which deviate from the predicted values by up to $\pm 10 \mu \mathrm{mol} / \mathrm{kg}$ per 
decade. This signal is comparable to or larger than the predicted secular trends over the 10 year sampling period. The MLR technique also has shortcomings primarily in its interpretation. Both methods have known problems in the upper $200 \mathrm{~m}$ and so cannot be applied robustly to this region.

\subsection{COUPLED-CARBON-CLIMATE-MODEL}

The CSM1.4-Carbon model [Doney et al., 2006] output is used as a synthetic dataset to address the question of anthropogenic $\mathrm{CO}_{2}$ detection and attribution. The model has fully coupled physical climate and carbon cycle modules for the ocean, atmosphere and land. The CSM1.4 model was developed in the framework of the National Center for Atmospheric Research (NCAR) Community Climate System Model (CCSM) [Blackmon et al., 2001]. The physical model is comprised of the NCAR Ocean Model (NCOM), the NCAR Land Surface Model (LSM), the Community Climate Model (CCM) and the Community Sea Ice Model (CSIM), which are coupled together so that mass and energy exchanges among the different reservoirs are conserved. The ocean model [Gent et al., 1998] is non-eddy resolving with a grid spacing of $3.6^{\circ}$ longitude and 0.8 to $1.8^{\circ}$ latitude with 25 vertical levels. The land and atmospheric model resolution is $\sim 3.75^{\circ}$ with 18 vertical levels (for the atmosphere). The carbon module for each component is spun up individually in order to minimize drifts in the global carbon inventories. The land biogeochemical model is a modified version of the Carnegie-Ames-

Stanford-Approach (CASA) model. The ocean biogeochemical model is derived from the 
OCMIP II biotic model described in Najjar et al. [1999; 2007]. Prognostic variables include DIC, dissolved organic matter (DOM), particulate organic matter (POM), phosphate $\left(\mathrm{PO}_{4}\right)$, dissolved organic phosphorus, oxygen $\left(\mathrm{O}_{2}\right)$, total dissolved inorganic iron, and alkalinity. Three significant modifications were made to the OCMIP II model: production (DOM, POM) is prognostically computed as a function of light, temperature, phosphate, and iron; iron is added as a limiting nutrient of biological production; and an iron cycle is incorporated into the model. Though ecosystem dynamics are not explicitly calculated in the model, model equations are fully prognostic. Therefore, there is no nudging or restoring of variables during the model runs. A full description of the coupled-climate model, including model biogeochemical equations, can be found in Doney et al. [2006].

A 1000-year control simulation of the CSM1.4 model compares reasonably well against observations, displaying stable surface temperatures $( \pm 0.10 \mathrm{~K})$ and atmospheric $\mathrm{CO}_{2}$ concentrations $( \pm 1.2 \mathrm{ppm})$, and relatively little deep ocean drift [Doney et al., 2006; Fung et al., 2005]. The largest discrepancies between the model and observations are in the equatorial Pacific Ocean in which CCM atmospheric dynamics create a dual ITCZ resulting in unrealistic precipitation patterns. Also in the equatorial Pacific, simulated ocean biogeochemistry results in unrealistically low export production due to excessive iron limitation and problems with upwelling parameterizations [Doney et al., 2006].

We focus on two model simulations: a 1000 year control run and the final 100 years from a transient run (1820-2100) forced with historic fossil fuel $\mathrm{CO}_{2}$ emissions up to 2000 and then the Intergovernmental Panel on Climate Change (IPCC) 'business as 
usual' (A2) emissions scenario [IPCC, 2001; Nakicenovic et al., 2000]. The transient run (1820-2100) was started on year 101 of the control run. Because the simulations use prescribed $\mathrm{CO}_{2}$ emissions rather than prescribed atmospheric $\mathrm{CO}_{2}$ trajectory, the model years do not exactly match actual calendar years. The simulated atmospheric $\mathrm{CO}_{2}$ concentration in year 2000 , therefore, is somewhat low compared to observations $(\sim 346.5$ ppmv compared with $\sim 367$ ppmv), lagging about 12 years behind reality. While the model $\mathrm{CO}_{2}$ concentrations cannot be directly matched to calendar years, the overall $\mathrm{CO}_{2}$ temporal trends for the $21^{\text {st }}$ century and the year $2100 \mathrm{CO}_{2}$ concentration $(\sim 765 \mathrm{ppmv})$ are comparable to those from other carbon-climate projections [Friedlingstein et al., 2006; Fung et al., 2005].

Anthropogenic $\mathrm{CO}_{2}$ is not explicitly tracked in the CSM1.4 model, therefore, the intrusion of anthropogenic $\mathrm{CO}_{2}$ into the ocean must be calculated from the model output. There are two approaches for this calculation. The first method computes $C_{\text {anthro }}$ by differencing the transient simulation and the corresponding time in the control run. However, because the physics of the fully coupled simulations evolve independently, the high frequency variability is not coherent between the control and transient simulations. Therefore, for the CSM1.4 model, this is not an ideal method. We follow the second approach, which takes advantage of the temporal-scale separation between natural variability and anthropogenic secular trend by applying a low pass filter to the high temporal resolution (monthly) output of the model. This removes the natural short term variability in the ocean carbon cycle revealing the underlying 'anthropogenic' increase. 
This smoothed estimate of $C_{\text {anthro }}$ is imperfect as it misses short term variations in the anthropogenic inventory caused by isopycnal heave.

The magnitude of the short term variability in $C_{\text {anthro }}$ is investigated using a pair of historical (1958-2004) ocean-only simulations [Lovenduski et al., 2007; Moore et al., 2004]. We compare the true $C_{\text {anthro }}$ estimate, calculated by differencing a control run and a transient run with identical surface forcing and nearly identical physical circulation, to a low-pass filter estimate of $C_{\text {anthro }}$ calculated using a spline fit to the transient run. The true $\mathrm{C}_{\text {anthro }}$ estimate and the low-pass filter estimate of $C_{\text {anthro }}$ for three representative latitudes are shown in Appendix A. This analysis indicates that the mean error introduced by the low-pass filter approximation of $\mathrm{C}_{\mathrm{anthro}}$ is $0.37 \mu \mathrm{mol} / \mathrm{kg}$ per decade for the depth range $200-2000 \mathrm{~m}$. The mode RMS deviation of the low-pass filter estimate from the true value for the ocean-only simulations is $0.13 \mu \mathrm{mol} / \mathrm{kg}$ per decade $(200-2000 \mathrm{~m})$. These errors are considerably smaller than either the natural variability or the errors in the $\Delta \mathrm{C}^{*}$ and MLR techniques, emphasized below. While the ocean-only simulations allow us to more accurately quantify $C_{\text {anthro, }}$, the coupled-carbon model allows for the exploration of future carbon scenarios that include changing ocean dynamics. For this study, a spline fit to CSM1.4 model output is used to calculate the low-pass filter estimate of $C_{\text {anthro, }}$, $\Delta C_{\text {anthro }}^{\text {predict }}$. Figure 2.1 shows CSM1.4 model DIC output for the A2 transient run and the corresponding 100 years of the control run for three representative model cells. Plotted in black are the spline fits used to estimate $\Delta C_{\text {anthro }}^{\text {predict }}$.

In the surface ocean (upper $50 \mathrm{~m}$ ), the $\mathrm{A} 2$ transient run exhibits an average DIC increase of $1.36 \mu \mathrm{mol} / \mathrm{kg} / \mathrm{yr}$ for the model period corresponding to the decade with an 
average atmospheric $\mathrm{CO}_{2}$ of $375 \mathrm{ppm}$ (approximately calendar years 2000-2010). This is in agreement with present day observed surface ocean DIC increases [Peng et al., 1998; Sabine et al., 2004a]. The accumulation of anthropogenic $\mathrm{CO}_{2}$ decreases rapidly with depth to an average value of $0.13 \mu \mathrm{mol} / \mathrm{kg} / \mathrm{yr}(2500-5000 \mathrm{~m})$ during this period. The spatial distribution of anthropogenic $\mathrm{CO}_{2}$ in the model is also consistent with Sabine et al. [2004a] who estimate that $23 \%$ of anthropogenic ocean carbon is stored in the North Atlantic (in the model $26 \%$ is in the North Atlantic), $9 \%$ is stored in the Southern Ocean (in the model $9 \%$ is in the Southern Ocean), and $50 \%$ is found in the upper $400 \mathrm{~m}$ (in the model $54 \%$ is above $400 \mathrm{~m}$ ).

We focus much of our analysis on a representative hydrographic section in the Atlantic Ocean. Monthly model output is extracted along a north-south transect at approximately $25^{\circ} \mathrm{W}$, corresponding to the WOCE A16 cruise track [Johnson and Gruber, 2007; Johnson et al., 2005; Peltola et al., 2005; Wanninkhof et al., 2006b]. This track was chosen because it bisects the Atlantic Ocean and includes both the North Atlantic Deep Water and Antarctic Intermediate water formation regions, two important portals for $\mathrm{CO}_{2}$ injection into the deep ocean. To mimic the sampling strategy of the repeat hydrography programs, the A16 transect analysis is conducted using A2 transient run model output for two months exactly 10 years apart (mean atmospheric $\mathrm{CO}_{2}=375 \mathrm{ppm}$ ). The arrows in Figure 2.1 indicate the months used for the A16 transect analysis. Similar to field data, this sampling scheme aliases model DIC variability on time scales from monthly to decadal. A global analysis is also conducted (section 2.7) 
using annual mean model output extracted for two years exactly 10 years apart; this aliases DIC variability on time scales from interannual to decadal.

\subsection{CALCULATIONS}

\subsection{1 $\Delta \mathrm{C}^{*}$ and $\Delta C_{\text {anthro }}^{C^{*}}$}

The $\Delta C^{*}$ analysis was conducted using Gruber et al.'s [1996] formulation of equation 2:

$\Delta C^{*}=C-\left.C_{e q}\left(S, \theta, A l k^{0}\right)\right|_{f C O 2=280 p p m}+r_{C: O 2}\left(O_{2}{ }^{s a t}-O_{2}\right)+1 / 2\left[\left(A l k^{0}-A l k\right)+r_{N: O 2}\left(O_{2}{ }^{\text {sat }}-\right.\right.$ $\left.\left.\mathrm{O}_{2}\right)\right]$

where $r_{\mathrm{C:O2}}$ and $r_{\mathrm{N}: \mathrm{O} 2}$ are the Redfield stoichiometric ratios for $\mathrm{C}_{\text {org }}: \mathrm{O}_{2}$ and $\mathrm{N}: \mathrm{O}_{2}$ respectively. In order to be consistent with the ocean biogeochemical model, Anderson and Sarmiento's [1994] modified Redfield ratios are used, $\mathrm{P}: \mathrm{N}: \mathrm{C}_{\mathrm{org}}: \mathrm{O}_{2}=1: 16: 117:-170$. $\mathrm{O}_{2}{ }^{\text {sat }}$ is the oxygen saturation concentration and is calculated using the equations of Weiss [1970]. $C_{e q}$ is the equilibrium DIC concentration given a pre-industrial atmosphere (atmospheric $\mathrm{CO}_{2}=280 \mathrm{ppm}$ ) and is calculated as a function of potential temperature $(\theta)$, salinity (S), preformed alkalinity $\left(\mathrm{Alk}^{0}\right)$, and $\mathrm{pCO}_{2}(280 \mathrm{ppm})$ using the $\mathrm{CO}_{2}$ System in Seawater code written by Zeebe and Wolf-Gladrow [2001; 2004]. Alk ${ }^{0}$ is the preformed alkalinity and is calculated using a multiple linear regression fit to upper ocean salinity (S), phosphorus $(\mathrm{P})$, and oxygen $\left(\mathrm{O}_{2}\right)$ for years 101-450 of the control run. Model concentrations are converted from volume normalized units to conventional mass 
normalized units using a constant conversion factor $\left(1026 \mathrm{~kg} / \mathrm{m}^{3}\right)$. Results are presented in $\mu \mathrm{mol} / \mathrm{kg}$ for depth profiles and $\mathrm{mol} / \mathrm{m}^{2}$ for column inventories.

The pre-industrial air-sea disequilibrium term $C_{\text {diseq }}(E q .3)$ is assumed to remain constant with time along an isopycnal surface such that $C_{\text {diseq }}\left(t_{1}\right)=C_{\text {diseq }}\left(t_{0}\right)$ [Gruber et al., 1996]. Therefore from equations 3 and 4:

$$
\Delta C_{\text {anthro }}^{C^{*}}=\left(\Delta C *\left(t_{1}\right)-C_{\text {diseq }}\left(t_{1}\right)\right)-\left(\Delta C^{*}\left(t_{0}\right)-C_{\text {diseq }}\left(t_{0}\right)\right)=\Delta C^{*}\left(t_{1}\right)-\Delta C^{*}\left(t_{0}\right)
$$

$\Delta C^{*}$ and $\Delta C_{\text {anthro }}^{C^{*}}$ are calculated along isopycnal surfaces using monthly mean model output roughly following the A16 transect and then projected back into depth space. The error introduced by this remapping is approximately $1.0 \mu \mathrm{mol} / \mathrm{kg}$. For the global calculations, $\Delta C^{*}$ and $\Delta C_{\text {anthro }}^{C^{*}}$ are calculated in depth space using annual mean model output due to computational constraints. We compare $\Delta C^{*}$ and $\Delta C_{\text {anthro }}^{C^{*}}$ calculated in depth and isopycnal space and conclude that, while small differences exist, both the magnitude of the $\Delta C_{\text {anthro }}^{C^{*}}$ estimate and the major trends are the same for both calculations.

\subsubsection{Multiple Linear Regression and $\Delta C_{\text {anthro }}^{M L R}$}

There is no standard set of physical and biogeochemical variables for DIC MLR. Therefore, the optimized MLR parameters differ depending upon the chosen variables and ocean region [Brewer et al., 1995; Friis et al., 2005]. As neither nitrate nor silicate is explicitly included in the model, we use oxygen and phosphate as the biogeochemical variables to compute the estimated DIC concentration, $C^{M L R}$ : 


$$
C^{M L R}=a+b \theta+c S+d O_{2}+e P O_{4}
$$

where $a$-e are the optimized MLR parameters $(p)$. Model concentrations are converted from volume normalized units to conventional mass normalized units $(\mu \mathrm{mol} / \mathrm{kg})$ using a constant conversion factor $\left(1026 \mathrm{~kg} / \mathrm{m}^{3}\right)$. Due to seasonal variability in the upper water column and differences between the hydrographic properties of thermocline and deep water masses, the MLR fits are done using temperature, salinity and nutrient output from 200-2000m. [Brewer et al., 1995; Sabine et al., 1999; Wallace, 1995]. Though these fits are then applied to the entire water column, our analysis focuses on the results from 2002000m, see discussion below. We perform a stepwise MLR (after Brewer et al. [1995]) to determine the number of variables needed to fit model DIC concentrations. The "best fit" is determined by comparing the $\mathrm{r}^{2}$ value and the root mean squared error (RMSE) of MLR fits using 1-4 variables. For CSM1.4 model output, including all four variables $\left(\mathrm{r}^{2}=0.99\right.$; standard deviation of residual for $\left.t_{0} \pm 4.98 \mu \mathrm{mol} / \mathrm{kg}\right)$ statistically improves the MLR fit to the DIC concentrations relative to regressions using only a subset of the variables.

Two types of MLR analyses have been used to estimate $\Delta C_{\text {antro }}(E q .5)$. The MLR method most commonly used by previous studies [Goyet and Davis, 1997; Peng, 2005; Peng et al., 2003; Sabine et al., 1999; Wallace, 1995] uses the MLR parameters fit at time $t_{0}, p\left(t_{0}\right)$, and the data from time $t_{1}$, data $\left(t_{1}\right)$, to compute $\mathrm{C}^{\mathrm{MLR}}\left(\mathrm{t}_{1}\right)$. The estimated DIC concentration for $t_{l}$ is then differenced from the observations at $t_{1}$ :

$$
\Delta C_{\text {anthro }}^{M L R}=C_{o b s}\left(t_{1}\right)-C^{M L R}\left[p\left(t_{0}\right), \operatorname{data}\left(t_{1}\right)\right]
$$


The extended MLR analysis (eMLR), introduced by Friis et al. [2005], replaces the DIC observations at time $t_{l}$ with a second MLR estimate using parameters and data from $t_{1}$ :

$$
\Delta C_{\text {anthro }}^{e M L R}=C^{M L R}\left[p\left(t_{1}\right), \operatorname{data}\left(t_{1}\right)\right]-C^{M L R}\left[p\left(t_{0}\right), \operatorname{data}\left(t_{1}\right)\right]
$$

The eMLR method results in a much smoother $\Delta C_{\text {anthro }}$ field. However, this smoother field is not necessarily more realistic. The MLR (Eq. 8) represents only that fraction of the total DIC variance that projects linearly onto the chosen physical and biogeochemical variables; the remaining variance falls into the regression residuals:

$$
C_{\text {resid }}^{M L R}\left(t_{i}\right)=C_{\text {obs }}\left(t_{i}\right)-C^{M L R}\left[p\left(t_{i}\right), \operatorname{data}\left(t_{i}\right)\right]
$$

which include both random noise and real geochemical signals. By analyzing the components of the MLR individually, we find that the MLR variables are highly correlated leading to large cancellations between the terms in equation 8. Substantial coherence between the MLR variables indicates that they are non-orthogonal and so poor basis functions for DIC. Coherence increases the likelihood that real DIC signals will not be mapped onto the MLR variables and therefore potentially valuable information will be left in the residuals.

The difference between the $\Delta C_{\text {anthro }}^{M L R}(E q .9)$ and $\Delta C_{\text {anthro }}^{e M L R}(E q .10)$ fields equals the MLR residuals for time $t_{1}$ :

$$
\Delta C_{\text {anthro }}^{M L R}-\Delta C_{\text {anthro }}^{\text {eMLR }}=C_{\text {obs }}\left(t_{1}\right)-C^{M L R}\left[p\left(t_{1}\right), \operatorname{data}\left(t_{1}\right)\right]=C_{\text {resid }}^{M L R}\left(t_{1}\right)
$$

The eMLR field is smoother because the "noise" of the residuals has been removed. Any coherent pattern in the residuals can lead to biases in MLR the estimate of $\Delta C_{\text {anthro }}$. The traditional MLR estimate of anthropogenic $\mathrm{CO}_{2}$ is biased because the MLR residuals from $t_{0}, C_{\text {resid }}^{M L R}\left(t_{0}\right)$, are incorporated into the estimate of $\Delta C_{a n t h r o}^{M L R}$. The eMLR is biased 
because it assumes that $C_{\text {resid }}^{M L R}\left(t_{1}\right)$ and $C_{\text {resid }}^{M L R}\left(t_{0}\right)$ will cancel. This assumption is difficult to justify as the residual fields are quite sensitive to the different regression parameters at the different times. These biases are inherent to the MLR technique and so apply to estimates of $\Delta C_{\text {anthro }}^{M L R}$ and $\Delta C_{\text {anthro }}^{e M L R}$ for both the model simulations and field observations.

\subsubsection{Upper Water Column Variability}

High seasonal variability in the upper water column makes it difficult to detect changes in anthropogenic carbon inventories in this region. Both the $\Delta C^{*}$ and MLR methods have known issues in the upper $200 \mathrm{~m}$ leading to less reliable estimates of $\Delta C_{\text {anthro }}$ [e.g. Matsumoto and Gruber, 2005; Wallace, 1995]. To avoid errors introduced by seasonal variability and to maintain consistency with the typical application of the $\Delta C^{*}$ and MLR methods, we focus our analysis on the region below $200 \mathrm{~m}$. For the decade under study (average atmospheric $\mathrm{CO}_{2}$ of $375 \mathrm{ppm}$ ), very little anthropogenic carbon has penetrated below $2000 \mathrm{~m}$, hence we further limit our focus region to $200-2000 \mathrm{~m}$. Tables 2.1 and 2.2 present results for both the $1-2000 \mathrm{~m}$ and $200-2000 \mathrm{~m}$ intervals. Inclusion of the upper 200m significantly increases both the DIC RMS $1 \sigma$ value for the control run, a measure of the natural variability in the system, and the RMS difference between the estimated and predicted $\Delta C_{\text {anthro }}$ values. This confirms that the upper water column has increased variability and that empirical methods are not robust in this region. Unless otherwise stated, all further analysis will be done for the 200- 2000m depth range, including all anthropogenic carbon inventory calculations. 


\subsection{REMOVING NATURAL VARIABILITY IN THE MODEL OCEAN CARBON SYSTEM}

The primary function of empirical methods like $\Delta \mathrm{C}^{*}$ and MLR is to remove the natural variability of the carbon system in order to reveal the underlying anthropogenic signal. To characterize the inter-annual to decadal variability in the model, we calculate the DIC RMS variability for the CSM1.4 model control run using mean monthly output. A 350 year period which spans the two transient runs is used for this analysis (control run years 101 to 450). For each model grid cell, the data is detrended by removing the model drift using a low pass filter and by removing the average seasonal cycle. Figure 2.2a shows a contour plot of the DIC $1 \sigma$ values for the section. The mean DIC RMS variability is $\pm 4.59 \mu \mathrm{mol} / \mathrm{kg}(1 \sigma, 0-2000 \mathrm{~m})$ or $2.29 \mu \mathrm{mol} / \mathrm{kg}(1 \sigma, 200-2000 \mathrm{~m})$. The mode of the RMS variability for the entire transect, representative of the RMS variability in the deep ocean, is $\pm 0.62 \mu \mathrm{mol} / \mathrm{kg}$. The surface ocean and high latitude North Atlantic are regions of high variability, with $1 \sigma$ values reaching $\pm 23.37 \mu \mathrm{mol} / \mathrm{kg}(0-2000 \mathrm{~m})$.

To determine the processes driving these large natural shifts in DIC, we examine the correlation between DIC anomalies and physical (temperature, salinity and air-sea gas exchange) and biogeochemical (oxygen, phosphorous, export production) properties. We analyze the properties controlling the month to month evolution of DIC using propertyproperty plots and covariance and multiple linear regression analysis. The near surface variability, particularly at high latitudes, is driven by vertical or lateral shifts in the 
boundary between water masses and by changes in water mass air-sea disequilibrium. A histogram of the mean monthly variance (not shown) exhibits high variability in the North Atlantic deep and mode water formation region, $40-60^{\circ} \mathrm{N}$ is driven by large anomalies in the spring following the winter-convection period. Finally, a spectral analysis indicates that interannual and decadal scale variability in subpolar regions is modulated on centennial time scales by model climate state; the interannual to decadal variability in subtropics and tropics is more uniform over the simulation.

We evaluate the ability of the $\Delta \mathrm{C}^{*}$ method to remove the natural variability in the model carbon cycle by calculating a spatial map of RMS $\Delta \mathrm{C}^{*}$ for the monthly outputs over a 350 year period of the control run. Non-zero $1 \sigma$ values reflect either errors in the $\Delta C^{*}$ construct or changes in air-sea disequilibrium $\left(\mathrm{C}_{\text {diseq }}\right)$. The $\Delta \mathrm{C}^{*}$ method is able to reduce but not fully eliminate the natural variability in surface waters, at the equator, and in the North Atlantic Deep Water formation region, indicating areas where potential biases may arise in $\Delta C_{\text {anthro }}^{C^{*}}$ (Figure 2.2b). We perform a similar test of the two MLR techniques, calculating maps of RMS $\Delta C^{M L R}$ and $\Delta C^{e M L R}$ for the same model time period. The baseline MLR parameters $p\left(t_{0}\right)(E q .8)$ are computed using the mean DIC, nutrient, and physical fields. For the 200-2000m region, the MLR and eMLR reduce the natural RMS variability of the inorganic carbon system by 2.5 and 7 fold respectively, a greater reduction than is achieved using the $\Delta \mathrm{C}^{*}$ method (Table 2.1). However, direct comparison of the (e)MLR and $\Delta C^{*}$ RMS values may be somewhat misleading as the MLR regressions do not capture all of the variance of original fields as discussed above. The highest $1 \sigma$ MLR and eMLR values are observed in the upper $200 \mathrm{~m}$ (Figure $2.2 c \&$ 
2.2d), where the MLR technique is not robust. Similar to the $\Delta \mathrm{C}^{*}$ method, the MLR displays high $1 \sigma$ values in the North Atlantic Deep Water formation region indicating that the $\Delta C_{a n t h r o}^{M L R}$ estimate will most likely be biased for this region because the MLR fit does not capture a substantial amount of the natural variability. The mean, maximum and mode $1 \sigma$ values for the control run, the $\Delta \mathrm{C}^{*}$ method, and the MLR techniques are presented in Table 2.1.

\subsection{DETECTING AND ATTRIBUTION OF TEMPORAL TRENDS IN ANTHROPOGENIC $\mathrm{CO}_{2}$}

The ability of the $\Delta \mathrm{C}^{*}$ and the MLR techniques to accurately estimate $\Delta C_{\text {anthro }}$ is tested by comparing the empirical estimates of the temporal change of anthropogenic $\mathrm{CO}_{2}\left(\Delta C_{\text {anthro }}^{C^{*}}, \Delta C_{\text {anthro }}^{M L R}, \Delta C_{\text {anthro }}^{e M L R}\right)$ to the predicted value for transient simulations, $\Delta C_{\text {anthro }}^{\text {predict }}$. This comparison is done for a 10 year period for which average Northern Hemisphere atmospheric $\mathrm{CO}_{2}$ is approximately 375ppm [GLOBALVIEW-CO2, 2005]. The following analysis highlights issues and potential biases in the two techniques. However, the magnitude of the errors for actual field data may differ somewhat due to errors, such as sampling and analytical errors, that are not accounted for in the model.

Similar to observations from repeat hydrography cruises [e.g. Wanninkhof et al., 2006a], the natural variability in the ocean carbon system leads to spatial noise in the plot of $\Delta$ DIC for any particular occupation (Figure 2.3a). This 'snap-shot' change in DIC differs substantially from the predicted invasion of anthropogenic $\mathrm{CO}_{2}, \Delta C_{\text {anthro }}^{\text {prediced }}$ (Figure 
2.4a), which is calculated using the low-pass filter as described above. The RMS error of the estimated $\Delta C_{\text {antho }}$ values from the predicted value is given by:

$$
\sigma=\sqrt{\frac{\sum\left(\Delta C_{\text {anthro }}^{\text {estimate }}-\Delta C_{\text {anthro }}^{\text {prediced }}\right)^{2}}{(N-1)}}
$$

where $\mathrm{N}$ is the number of values being compared. The RMS error for each technique is given in Table 2.2. Figures $2.4 b, 2.4 c$, and $2.4 d$ show the difference between $\Delta C_{a n t h r o}^{C^{*}}$, $\Delta C_{\text {anthro }}^{M L R}, \Delta C_{\text {anthro }}^{e M L R}$ and $\Delta C_{\text {anthro }}^{\text {prediced }}$, respectively. The average percent error is calculated as:

$\%$ error $=\frac{\left|\Delta C_{\text {anthro }}-\Delta C_{\text {anthro }}^{\text {prediced }}\right|}{\Delta C_{\text {anthro }}^{\text {predict }}} \times 100$

using only points with significant anthropogenic carbon, $\Delta C_{\text {anthro }}^{\text {prediced }} \geq 3 \mu \mathrm{mol} / \mathrm{kg} / \mathrm{decade}$. The average percent error for decadal differences for the MLR, eMLR and $\Delta \mathrm{C}^{*}$ methods are $82.0 \%, 25.5 \%$, and $24.1 \%$, respectively. These errors are consistent with previous error estimates for these techniques [Friis et al., 2005; Gruber et al., 1996]. While the average errors for the eMLR and $\Delta C^{*}$ techniques are similar, the distribution of the errors differ substantially. The eMLR errors are evenly distributed over the entire transect whereas the $\Delta \mathrm{C}^{*}$ method performs better overall but has regions with extremely large deviations from $\Delta C_{\text {anthro }}^{\text {prediced }}$.

The $\Delta \mathrm{C}^{*}$ method is able to account for the majority of the natural variability in the system and provides a fairly accurate estimate of anthropogenic $\mathrm{CO}_{2}$ at low and mid latitudes $\left(40^{\circ} \mathrm{S}\right.$ to $\left.30^{\circ} \mathrm{N}\right)$. However, at the high latitudes, $\Delta C_{\text {anthro }}^{C^{*}}$ differs from the predicted value by up to $11 \mu \mathrm{mol} / \mathrm{kg}$. These errors are large relative to the mean and 
maximum predicted anthropogenic signal $\left[\Delta C_{\text {anthro }}^{\text {predicted }}(\right.$ mean $)=3.02 \mu \mathrm{mol} / \mathrm{kg}, \Delta C_{\text {anthro }}^{\text {predicted }}$ $(\max )=12.75 \mu \mathrm{mol} / \mathrm{kg})]$. This discrepancy could be due to either errors in the $\Delta C^{*}$ construct or in the assumptions made about the constancy of the air-sea disequilibrium term $\left(\mathrm{C}_{\text {diseq }}\right)$ along isopycnal surfaces.

We look at changes in temperature, salinity, phosphorus, and oxygen over the 10 year study period to explain the discrepancy between $\Delta C_{\text {anthro }}^{C^{*}}$ and $\Delta C_{\text {anthro }}^{\text {predicted }}$ at high latitudes. While temperature, salinity, and phosphorus exhibit only small changes over this time period, there are large changes in apparent oxygen utilization $\left(\mathrm{AOU}=\mathrm{O}_{2}\right.$ sat $\mathrm{O}_{2}$, Figure 2.3b). At high latitudes, areas with large changes in AOU correlate well with regions in which $\Delta C_{\text {anthro }}^{C^{*}}$ deviates from $\Delta C_{\text {anthro }}^{\text {predict }}$. In particular, large positive changes in AOU are associated with $\Delta \mathrm{C}^{*}$ underestimating the increase in anthropogenic $\mathrm{CO}_{2}$. Figure 2.5 shows the strong correlation between $\Delta C_{\text {anthro }}^{\text {predicted }}-\Delta C_{\text {anthro }}^{C^{*}}$ and $\triangle A O U$ for the high latitudes $\left(40-70^{\circ} \mathrm{S}\right.$ and $\left.30-90^{\circ} \mathrm{N}\right)$. Both $\Delta C_{\text {anthro }}^{C^{*}}$ and $\Delta \mathrm{AOU}$ are calculated using mean monthly model output in isopycnal space and then mapped back into depth space.

In the case where the $\Delta C^{*}$ method reproduces the predicted $\Delta C_{\text {anthro }}$ signal, the data points in a plot of $\Delta C_{\text {anthro }}^{\text {prediced }}-\Delta C_{\text {anthro }}^{C^{*}}$ vs. $\triangle A O U$ will fall along the $\mathrm{x}$-axis (represented by the light gray line in Figure 2.5). Movement along this line is caused by changes in $C_{b i o}(E q .2)$, where increases in $C_{b i o}$ move data points to the right and decreases in $C_{\text {bio }}$ move points to the left (represented by the light gray arrow in Figure 2.5). Deviations from this ideal case are caused by changes in $\mathrm{O}_{2}$ and DIC air-sea disequilibrium, for DIC represented by the $C_{\text {diseq }}$ term $(E q .3)$. The $\Delta C^{*}$ method assumes that oxygen is always saturated in surface waters, and therefore incorrectly attributes $\mathrm{O}_{2}$ 
air-sea disequilibrium (non-zero surface AOU values) to biologic activity. An increase in AOU disequilibrium, water leaving the surface with less $\mathrm{O}_{2}$ and a higher AOU, is thus treated as an increase in biologic activity and results in an underestimate of $\Delta C_{\text {anthro }}$, and vice versa. This moves data points off of the x-axis with a slope of $r_{C: A O U}, 117: 170$, (represented by the black arrow in Figure 2.5). The $\Delta \mathrm{C}^{*}$ method also assumes that the pre-industrial DIC air-sea disequilibrium remains constant with time; $C_{\text {diseq }}\left(t_{1}\right)-C_{\text {diseq }}\left(t_{0}\right)$ from equation 7 equals zero as discussed above. Therefore, an increase in $C_{\text {diseq, }}$, water leaving the surface with more DIC, will result in an overestimate of $\Delta C_{\text {anthro }}$, and vice versa. This moves data points in the $\Delta C_{\text {anthro }}^{\text {predicted }}-\Delta C_{\text {anthro }}^{C^{*}}$ vs. $\triangle A O U$ plot vertically (represented by the dark gray arrow in Figure 2.5). The best-fit line in Figure 2.5 (plotted as a dashed black line) is therefore an amalgamation of the AOU disequilibrium line (the black arrow) and the $\Delta C_{\text {diseq }}$ line (the dark gray arrow). We conclude that the majority of the discrepancy between $\Delta C_{\text {anthro }}^{C^{*}}$ and $\Delta C_{\text {anthro }}^{\text {prediced }}$ at high latitudes is due to variability in AOU disequilibrium in the surface waters which is not accurately accounted for by the $\Delta C^{*}$ method. This bias is partially offset by changes in the $\Delta C_{\text {diseq }}$ term, which is also not accounted for by the $\Delta C^{*}$ method. These findings are similar to the findings of Wanninkhof et al. [2006a].

The bias in the $\Delta \mathrm{C}^{*}$ calculation due to $\mathrm{O}_{2}$ air-sea disequilibrium can be eliminated by using $\mathrm{PO}_{4}$ instead of $\mathrm{O}_{2}$ to correct for changes in the biologic pump [Gruber and Sarmiento, 2002]. This can be accomplished by substituting the change in phosphorus, $r_{C: P O 4}\left(P_{4}{ }^{0}-P_{4}\right)$ where $\mathrm{PO}_{4}{ }^{0}$ is preformed $\mathrm{PO}_{4}$, for $r_{\mathrm{C:O}}\left(\mathrm{O}_{2}{ }^{\text {sat }}-\mathrm{O}_{2}\right)$ in equation 6. 
Unfortunately this substitution introduces a new set of difficulties. Namely, we do not have a direct method for determining $\mathrm{PO}_{4}{ }^{0}$. Hydrographic surveys also face the problem that the fractional uncertainties for $\mathrm{PO}_{4}$ measurements are high and studies have shown that $\mathrm{C}: \mathrm{P}$ ratios vary with depth due to preferential remineralization of phosphorus [e.g. Martin et al., 1987]. Here we estimate $\Delta C_{\text {anthro }}$ using $\Delta C_{\text {anthro }}^{C^{*} P_{4}}$ by assuming that $\mathrm{PO}_{4}{ }^{0}$ remains constant along isopycnal surfaces and therefore cancels in the calculation of $\Delta C_{\text {anthro }}^{C^{*} P_{4}}$. Due to the inaccuracies of this assumption, the $\Delta C_{\text {anthro }}^{C^{*_{P O}}}$ estimate still differs significantly from $\Delta C_{\text {anthro }}^{\text {predict }}($ Table 2.2).

For the same 10 year period, we calculate $\Delta C_{\text {anthro }}$ using both the MLR and the eMLR techniques. The MLR coefficients and their $1 \sigma$ errors for $t_{0}\left(\right.$ time $\left._{0}\right)$ and $t_{l}($ time 1$)$ are given in Table 2.3. The residual error for the MLR fit to the model DIC concentrations at $\mathrm{t}_{0}$ is $\pm 4.98 \mu \mathrm{mol} / \mathrm{kg}\left(\mathrm{r}^{2}=0.990, \mathrm{n}=1194\right)$ and at $\mathrm{t}_{1}$ is $\pm 5.81 \mu \mathrm{mol} / \mathrm{kg}$ $\left(r^{2}=0.985, n=1194\right)$. These errors are approximately the same as the residual error for MLR fits to field observations, $\sim 6 \mu \mathrm{mol} / \mathrm{kg}$ [Brewer et al., 1995; Friis et al., 2005]. However, the model MLR residual error is most likely small due to a tight correlation between changes in $\mathrm{PO}_{4}$ concentration and biologic activity in the model. For field observations, including either nitrate or silicate as MLR parameters is often necessary to obtain a low residual error [Brewer et al., 1995; Friis et al., 2005]. As neither nitrate nor silicate is tracked in the model, we are forced to use only oxygen and phosphorus as biological variables.

While $\Delta C_{\text {anthro }}^{M L R}$ accurately reproduces the spatial distribution of anthropogenic $\mathrm{CO}_{2}$ along the section, it significantly over-estimates the magnitude of the predicted signal by 
greater than $15 \mu \mathrm{mol} / \mathrm{kg}$ in the upper $2000 \mathrm{~m}$ (Figure 2.6a, 2.4c). The RMS error of $\Delta C_{\text {anthro }}^{M L R}$ relative to $\Delta C_{\text {anthro }}^{\text {predict }}$ is $5.04 \mu \mathrm{mol} / \mathrm{kg}$, significantly greater than all other empirical methods tested in this study (Table 2.2). This error is caused by large MLR residuals that bias the $\Delta C_{\text {anthro }}^{M L R}$ estimate, as discussed above. The residuals for the MLR fit to $t_{l}$ are shown in Figure 2.6b. By subtracting the MLR $t_{l}$ residuals from the $\Delta C_{\text {anthro }}^{M L R}$ estimate, one arrives at $\Delta C_{\text {anthro }}^{e M L R}(E q .12)$ which better matches $\Delta C_{\text {anthro }}^{\text {predted }}$. The difference between $\Delta C_{\text {anthro }}^{\text {preicted }}$ and $\Delta C_{\text {anthro }}^{\text {eMLR }}$ is shown in Figure 2.4d. The eMLR estimate displays both the same spatial distribution and magnitude as the predicted signal. However, as discussed above, the eMLR method produces a biased $\Delta C_{\text {anthro }}$ estimate when there is structure in the MLR residuals.

\subsection{EFFECTS ON INVENTORIES}

Estimates of anthropogenic carbon are most frequently presented as either column, basin, or global inventories with different methods providing significantly different inventory estimates. Here we compare the predicted temporal change in the column inventory calculated from $\Delta C_{\text {anthro }}^{\text {predicted }}$ to the column inventories calculated from the $\Delta C_{\text {anthro }}^{C^{*}}, \Delta C_{\text {anthro }}^{M L R}$, and $\Delta C_{\text {anthro }}^{e M L}$ estimates for the model output extracted along the A16 transect for a decade approximately equal to 2000-2010 (Figure 2.7). The MLR inventory estimates deviate significantly from the predicted inventory for the majority of the section with the largest overestimate occurring in the North Atlantic between $40^{\circ}-60^{\circ} \mathrm{N}$ and the largest underestimate occurring between $0^{\circ}-40^{\circ} \mathrm{N}$ and $>80^{\circ} \mathrm{N}$. The $\Delta C^{*}$ and eMLR 
methods more accurately reproduce the predicted inventory. At low and mid latitudes $\left(40^{\circ} \mathrm{S}-40^{\circ} \mathrm{N}\right)$, the $\Delta \mathrm{C}^{*}$ inventory matches the predicted inventory and the eMLR slightly overestimates the column inventory. In the Southern Ocean, the eMLR reproduces the predicted inventory whereas the $\Delta \mathrm{C}^{*}$ estimate displays significant deviations from the predicted inventory. Finally, in the North Atlantic, the $\Delta \mathrm{C}^{*}$ technique overestimates the anthropogenic inventory and the eMLR underestimates the anthropogenic inventory. Our previous analysis showed that $\Delta C^{*}$ significantly underestimates $\Delta C_{\text {anthro }}$ concentrations in the upper $500 \mathrm{~m}$ between 40 and $60^{\circ} \mathrm{N}$ relative to the predicted signal (Figure $2.4 b$ ). However, the column inventory for this region shows that $\Delta \mathrm{C}^{*}$ overestimates the $\Delta C_{\text {anthro }}$ inventory (Figure 2.7). Similarly, the model transect analysis showed that the eMLR approach reproduces the predicted signal in the North Atlantic (Figure 2.4d) whereas the inventory analysis indicates that the eMLR significantly underestimates $\Delta C_{\text {anthro }}$ in this region (Figure 2.7). The discrepancies between the depth distribution of $\Delta C_{\text {anthro }}$ along the model transect and the column inventories for the model transect highlights the fact that small errors in these methods can result in significant discrepancies in inventory calculations when integrated over large depth ranges.

\subsection{GLOBAL ANALYSIS}

As a final check of the $\Delta \mathrm{C}^{*}$ and MLR techniques, we analyze their ability to estimate both spatial patterns in water column inventory and the global inventory of anthropogenic carbon in the oceans by applying them to the global output of the CSM1.4 
model. The natural variability of the global carbon system is estimated by calculating the RMS variability of the DIC column inventories for control run model years 101 to 450 using detrended annual mean model output. The highest variability occurs in the mode and deep water formation regions; the North Atlantic, the North-west Atlantic, and the North-west Pacific Ocean (Figure 2.8a). The boundary between the Southern Ocean and the Indio-Pacific Oceans is also a region of increased variability. Similar to the transect analysis, we test the ability of the $\Delta C^{*}$ and MLR techniques to remove the natural variability in the model ocean carbon system by calculating $\Delta C_{\text {anthro }}^{C^{*}}, \Delta C_{\text {anthro }}^{M L R}$, and $\Delta C_{\text {anthro }}^{e M L R}$ for the control run using detrended annual mean model output for model years 101 to 450. The MLR calculations are done by basin (Atlantic, Pacific, Southern Ocean, Indian, and Arctic) as different water masses display different regional relationships between temperature, salinity and the nutrients. This basin approach reduces the RMS $1 \sigma$ difference between $\Delta C_{\text {anthro }}^{\text {predicted }}$ and $\Delta C_{\text {anthro }}^{M L R}$ column inventories by $16.73 \mathrm{~mol} / \mathrm{m}^{2}$ compared to the RMS difference for a single MLR fit. All MLR fits are done for 200-2000m and baseline MLR parameters $p\left(t_{0}\right)(E q .8)$ are computed using the mean DIC, nutrient, and physical fields. The results are similar to those of the model transect analysis. The $\Delta C^{*}$ method is able to remove the majority of the natural variability in the ocean carbon system but fails to account for some variability in the mode and deep water formation regions, particularly in the North Atlantic (Figure 2.8b). The MLR approaches also reduce the natural DIC variability but fail to account for some of the variability in the North Atlantic, South Atlantic and North Indian Ocean (Figure 2.8c and 2.8d). These areas, where the empirical methods are unable to remove all the variability in the natural 
carbon system, indicate regions where these empirical methods might not produce an accurate estimate of $\Delta C_{\text {anthro. }}$.

Using a low-pass filter applied to the annual mean model output for each model cell, we estimate the predicted anthropogenic signal for the global output of the transient run, 2000-2100, and calculate the change in the column inventories for the decade with an average atmospheric $\mathrm{CO}_{2}$ of $375 \mathrm{ppm}$. The predicted estimate of the global accumulation of anthropogenic carbon is $23.2 \mathrm{PgC} /$ decade or $12.1 \mathrm{PgC} / \mathrm{dec}$ de for 200 $2000 \mathrm{~m}$. The spatial distribution of the predicted accumulation for $200-2000 \mathrm{~m}$ is shown in Figure 2.9a. The difference between the column inventories of the model DIC output for the decade under study yields a similar column inventory of $22.7 \mathrm{PgC} / \mathrm{dec}$ ade or 11.7 $\mathrm{PgC} /$ decade for $200-2000 \mathrm{~m}$. However, there are significant discrepancies between the predicted distribution of anthropogenic $\mathrm{CO}_{2}$ and the 'snap-shot' difference in DIC. Applying the $\Delta \mathrm{C}^{*}$, MLR and eMLR techniques to the global model output yields global inventory estimates for $200-2000 \mathrm{~m}$ of $14.3,14.8$ and $13.6 \mathrm{PgC} /$ decade respectively. The differences between $\Delta C_{\text {anthro }}^{\text {prediced }}$ and $\Delta C_{\text {anthro }}^{C^{*}}, \Delta C_{\text {anthro }}^{M L R}$, and $\Delta C_{\text {anthro }}^{e M L R}$ are shown in Figure $2.9 b, 2.9 c$ and $2.9 d$ respectively. Both methods capture the basic trends of the predicted signal but tend to overestimate $\Delta C_{a n t h r o}$ in some regions and underestimate $\Delta C_{a n t h r o}$ in others. For example, the $\Delta \mathrm{C}^{*}$ method overestimates $\Delta C_{\text {anthro }}$ in the North Atlantic and South Pacific and slightly underestimates $\Delta C_{\text {anthro }}$ in regions of the Southern Ocean. On the other hand, the eMLR underestimates $\Delta C_{\text {anthro }}$ in the North Atlantic and overestimates $\Delta C_{\text {anthro }}$ in the South Atlantic. The MLR shows the largest deviations from the predicted values (note the scale difference in Figure 2.9c) with large overestimates in the North 
Atlantic and North Indian Ocean and large underestimates in the tropical Atlantic, Southwest Pacific and along the Southern Ocean boundary.

\subsection{DISCUSSION AND SUMMARY}

Using the output of a coupled carbon-climate model, we evaluate the ability of empirical techniques to accurately estimate the uptake of anthropogenic carbon, $\Delta C_{\text {anthro }}$, on decadal time scales in the presence of natural variability. This analysis shows that the $\Delta C^{*}$ and the extended MLR techniques have similar average errors for decadal differences (24\% and 26\% respectively), similar RMS errors (but somewhat different error sources and patterns), and both reproduce the spatial and temporal trends of the predicted anthropogenic signal for the majority of the ocean. However, this study also identifies regions where the empirical estimates of $\Delta C_{\text {anthro }}$ may introduce errors. Specifically the $\Delta \mathrm{C}^{*}$ estimates of $\Delta C_{\text {anthro }}$ may contain errors at high latitudes, particularly in mode and deep water formation regions, due to variations in $\mathrm{O}_{2}$ and DIC air-sea disequilibrium. The MLR techniques are biased by structure in the MLR residuals resulting from coherence between the MLR variables. Similar to the $\Delta C^{*}$ method, this is particularly apparent in mode and deep water formation regions where the residuals show significant degrees of structure. In addition, both empirical methods have difficulty in the upper $200 \mathrm{~m}$ due to high seasonal variability. Due to these potentially substantial errors in the empirical estimates of $\Delta C_{a n t h r o}$, we suggest that multiple empirical techniques should be used to estimate increases of anthropogenic carbon in the ocean. Specifically, careful 
attention should be paid to regions with significant differences between empirical estimates as this indicates that neither estimate is particularly robust and that further investigation is needed to fully characterize the underlying natural variability of the system.

The results of this study also have significant implications for repeat hydrography programs, such as CLIVAR/ $\mathrm{CO}_{2}$. While decadal occupations might be sufficient to estimate the temporal change in $C_{\text {anthro }}$ for some regions of the ocean, this study suggests that there are regions where more frequent observations may be needed in order to better constrain the natural variability of the carbon system and therefore the anthropogenic signal; for example in mode, intermediate and deep water formation regions, such as in the subpolar North Atlantic. With increased temporal resolution, short term natural variability in the ocean carbon system can be separated from the longer term anthropogenic trend using approaches similar to the spline-fitting method presented above or by using the detailed record to more accurately attribute changes in DIC to biological and physical processes.

A semivariogram analysis indicates that highly variable regions, such as the subpolar North Atlantic, have very short correlation timescales, on the order of half a year (Figure 2.10), indicating that sub-annual sampling is necessary to capture the full variability of the system. This is confirmed by an analysis of the fraction of the total variance captured under a variety of sampling scenarios ranging from every 2 months to every 10 years. In regions with low variability (e.g. $29^{\circ} \mathrm{S}, 415 \mathrm{~m}$ ), sub-sampling once every two years captures nearly all of the variability in the system (not shown). However, 
in regions of high variability (e.g. $55^{\circ} \mathrm{N}, 245 \mathrm{~m}$ ), sub-sampling once a year captures only $78 \%$ of the total variability when raw data is analyzed and $86 \%$ of the total variability when de-seasonalized data is analyzed (Figure 2.10). As such sub-annual sampling is impractical using traditional ship-based methods, we recommend that reoccupations be augmented, where possible, with alternative sampling platforms (e.g. moorings and profiling floats) and coherence with other biogeochemical variables such as $\mathrm{O}_{2}$ and nutrients. 


\subsection{ACKNOWLEDGEMENTS}

We would like to acknowledge funding from NSF (OCE02-23869), NCAR, the WHOI Ocean Climate Institute, a Linden Earth Systems Graduate Fellowship (MIT) and a National Defense Science and Engineering Graduate Fellowship. NCAR is sponsored by the National Science Foundation. RW is supported by the Office of Oceanic and Atmospheric Research at NOAA. We would also like to acknowledge the helpful comments of anonymous reviewers.

\subsection{REFERENCES}

Anderson, L. A., and J. L. Sarmiento (1994), Redfield Ratios of Remineralization Determined by Nutrient Data-Analysis, Global Biogeochemical Cycles, 8(1), 65-80.

Blackmon, M., et al. (2001), The Community Climate System Model, Bulletin of the American Meteorological Society, 82, 2357-2376.

Brewer, P. G. (1978), Direct Observation of Oceanic $\mathrm{CO}_{2}$ Increase, Geophys. Res. Lett., 5(12), 997-1000.

Brewer, P. G., D. M. Glover, C. Goyet, and D. K. Shafer (1995), The pH of the NorthAtlantic Ocean - Improvements to the Global-Model for Sound-Absorption in Seawater, Journal of Geophysical Research-Oceans, 100(C5), 8761-8776.

Chen, G. T., and F. J. Millero (1979), Gradual Increase of Oceanic $\mathrm{CO}_{2}$, Nature, 277(5693), 205-206.

Coatanoan, C., C. Goyet, N. Gruber, C. L. Sabine, and M. Warner (2001), Comparison of two approaches to quantify anthropogenic $\mathrm{CO}_{2}$ in the ocean: Results from the northern Indian Ocean, Global Biogeochemical Cycles, 15(1), 11-25.

Dilling, L., S. C. Doney, J. Edmonds, K. R. Gurney, R. Harriss, D. Schimel, B. Stephens, and G. Stokes (2003), The role of carbon cycle observations and knowledge in carbon management, Annual Review of Environment and Resources, 28, 521-558.

Doney, S. C., K. Lindsay, I. Fung, and J. John (2006), Natural variability in a stable, 1000-yr global coupled climate-carbon cycle simulation, Journal of Climate, 19(13), 3033-3054.

Etheridge, D. M., L. P. Steele, R. L. Langenfelds, R. J. Francey, J. M. Barnola, and V. I. Morgan (1996), Natural and anthropogenic changes in atmospheric $\mathrm{CO}_{2}$ over the last 
1000 years from air in Antarctic ice and firn, Journal of Geophysical ResearchAtmospheres, 101(D2), 4115-4128.

Feely, R. A., R. Wanninkhof, T. Takahashi, and P. Tans (1999), Influence of El Nino on the equatorial Pacific contribution to atmospheric $\mathrm{CO}_{2}$ accumulation, Nature, 398(6728), 597-601.

Friedlingstein, P., et al. (2006), Climate-carbon cycle feedback analysis: Results from the $\mathrm{C}^{4}$ MIP model intercomparison, Journal of Climate, 19(14), 3337-3353.

Friis, K., A. Kortzinger, J. Patsch, and D. W. R. Wallace (2005), On the temporal increase of anthropogenic $\mathrm{CO}_{2}$ in the subpolar North Atlantic, Deep-Sea Research Part IOceanographic Research Papers, 52(5), 681-698.

Fung, I. Y., S. C. Doney, K. Lindsay, and J. John (2005), Evolution of carbon sinks in a changing climate, Proceedings of the National Academy of Sciences of the United States of America, 102(32), 11201-11206.

Gent, P. R., F. O. Bryan, G. Danabasoglu, S. C. Doney, W. R. Holland, W. G. Large, and J. C. McWilliams (1998), The NCAR Climate System Model global ocean component, Journal of Climate, 11(6), 1287-1306.

GLOBALVIEW-CO2 (2005), Cooperative Atmospheric Data Integration Project Carbon DioxideRep., NOAA CMDL, Boulder, Colorado [can be found at ftp.cmdl.noaa.gov, Path: ccg/co2/GLOBALVIEW].

Goyet, C., and D. Davis (1997), Estimation of total $\mathrm{CO}_{2}$ concentration throughout the water column, Deep-Sea Research Part I-Oceanographic Research Papers, 44(5), 859877.

Goyet, C., C. Coatanoan, G. Eischeid, T. Amaoka, K. Okuda, R. Healy, and S. Tsunogai (1999), Spatial variation of total $\mathrm{CO}_{2}$ and total alkalinity in the northern Indian Ocean: A novel approach for the quantification of anthropogenic $\mathrm{CO}_{2}$ in seawater, Journal of Marine Research, 57(1), 135-163.

Gruber, N. (1998), Anthropogenic $\mathrm{CO}_{2}$ in the Atlantic Ocean, Global Biogeochemical Cycles, 12(1), 165-191.

Gruber, N., and J. Sarmiento (2002), Biologeochemical/Physical Interactions in Elemental Cycles, in THE SEA: Biological-Physical Interactions in the Oceans, edited by A. R. Robinson, J. J. McCarthy and B. J. Rothschild, pp. 337-399, John Wiley and Sons.

Gruber, N., J. L. Sarmiento, and T. F. Stocker (1996), An improved method for detecting anthropogenic $\mathrm{CO}_{2}$ in the oceans, Global Biogeochemical Cycles, 10(4), 809-837. 
Haine, T. W. N., and S. L. Gray (2001), Quantifying mesoscale variability in ocean transient tracer fields, Journal of Geophysical Research-Oceans, 106(C7), 13861-13878.

Hansen, J., M. Sato, R. Ruedy, K. Lo, D. W. Lea, and M. Medina-Elizade (2006), Global temperature change, Proceedings of the National Academy of Sciences of the United States of America, 103(39), 14288-14293.

IPCC (2001), Climate Change 2001: The Scientific Basis. Contribution of Working Group I to the Third Assessment Report of the Intergovernmental Panel on Climate Change 881 pp., Cambridge University Press, Cambridge, United Kingdom and New York, NY, USA.

Johnson, G. C., and N. Gruber (2007), Decadal water mass variations along 20 degrees W in the Northeastern Atlantic Ocean, Progress in Oceanography, 73(3-4), 277-295.

Johnson, G. C., J. L. Bullister, and N. Gruber (2005), Labrador Sea Water property variations in the northeastern Atlantic Ocean, Geophys. Res. Lett., 32(7).

Keeling, C. D., and T. P. Whorf (1994), Atmospheric $\mathrm{CO}_{2}$ records from sites in the SIO air sampling network, in Trends '93: A Compendium of Data on Global Change edited by T. A. Boden, D. P. Kaiser, R. J. Sepanski and F. W. Stoss, pp. 16-26, ORNL/CDIAC-65, Carbon Dioxide Information Analysis Center, Oak Ridge National Laboratory, Oak Ridge, Tennessee.

Keeling, C. D., R. B. Bacastow, A. E. Bainbridge, C. A. Ekdahl, P. R. Guenther, L. S. Waterman, and J. F. S. Chin (1976), Atmospheric Carbon-Dioxide Variations at MaunaLoa Observatory, Hawaii, Tellus, 28(6), 538-551.

Le Quere, C., O. Aumont, P. Monfray, and J. Orr (2003), Propagation of climatic events on ocean stratification, marine biology, and $\mathrm{CO}_{2}$ : Case studies over the 1979-1999 period, Journal of Geophysical Research-Oceans, 108(C12).

Lee, K., et al. (2003), An updated anthropogenic $\mathrm{CO}_{2}$ inventory in the Atlantic ocean, Global Biogeochemical Cycles, 17(4).

Lo Monaco, C., C. Goyet, N. Metzl, A. Poisson, and F. Touratier (2005), Distribution and inventory of anthropogenic $\mathrm{CO}_{2}$ in the Southern Ocean: Comparison of three data-based methods, Journal of Geophysical Research-Oceans, 110(C9).

Lovenduski, N. S., N. Gruber, S. C. Doney, and I. D. Lima (2007), Enhanced CO2 outgassing in the Southern Ocean from a positive phase of the Southern Annular Mode, Global Biogeochemical Cycles, 21(2). 
Martin, J. H., G. A. Knauer, D. M. Karl, and W. W. Broenkow (1987), Vertex - Carbon Cycling in the Northeast Pacific, Deep-Sea Research Part a-Oceanographic Research Papers, 34(2), 267-285.

Matsumoto, K., and N. Gruber (2005), How accurate is the estimation of anthropogenic carbon in the ocean? An evaluation of the $\Delta \mathrm{C}^{*}$ method, Global Biogeochemical Cycles, 19(3).

McNeil, B. I., R. J. Matear, R. M. Key, J. L. Bullister, and J. L. Sarmiento (2003), Anthropogenic $\mathrm{CO}_{2}$ uptake by the ocean based on the global chlorofluorocarbon data set, Science, 299(5604), 235-239.

Moore, J. K., S. C. Doney, and K. Lindsay (2004), Upper ocean ecosystem dynamics and iron cycling in a global three-dimensional model, Global Biogeochemical Cycles, 18(4).

Najjar, R., and J. Orr (1999), Biotic-HOWTORep., 15 pp, LSCE/CEA Saclay, Gif-surYvette, France.

Najjar, R., et al. (2007), Impact of circulation on export production, dissolved organic matter, and dissolved oxygen in the ocean: Results from Phase II of the Ocean Carboncycle Model Intercomparison Project (OCMIP-2), Global Biogeochemical Cycles, 21.

Nakicenovic, N., et al. (2000), Special Report on Emission Scenarios, 612 pp., Cambridge Univ. Press, Cambridge, UK.

Peacock, S., M. Maltrud, and R. Bleck (2005), Putting models to the data test: a case study using Indian Ocean CFC-11 data, Ocean Modeling, 9(1), 1-22.

Peltola, E., R. Wanninkhof, R. Feely, R. Castle, D. Greeley, J.-Z. Zhang, F. J. Millero, N. Gruber, J. L. Bullister, and T. Graham (2005), Inorganic carbon, nutrient, and oxygen data from the R/V RONALD $\mathrm{H}$. BROWN repeat hydrography cruise in the Atlantic Ocean: CLIVAR $\mathrm{CO}_{2}$ section A16N_2003A (4 June -11 August, 2003)Rep., 20 pp, ORNL RNL/CDIAC-149 NDP-085, Oak Ridge, Tennessee (http://cdiac.ornl.gov/oceans/ndp 085/NDP-085.html).

Peng, T. H. (2005), Anthropogenic $\mathrm{CO}_{2}$ in the ocean, Scientia Marina, 69, 85-96.

Peng, T. H., R. Wanninkhof, and R. A. Feely (2003), Increase of anthropogenic $\mathrm{CO}_{2}$ in the Pacific Ocean over the last two decades, Deep-Sea Research Part Ii-Topical Studies in Oceanography, 50(22-26), 3065-3082.

Peng, T. H., R. Wanninkhof, J. L. Bullister, R. A. Feely, and T. Takahashi (1998), Quantification of decadal anthropogenic $\mathrm{CO}_{2}$ uptake in the ocean based on dissolved inorganic carbon measurements, Nature, 396(6711), 560-563. 
Quay, P., R. Sonnerup, T. Westby, J. Stutsman, and A. McNichol (2003), Changes in the ${ }^{13} \mathrm{C} /{ }^{12} \mathrm{C}$ of dissolved inorganic carbon in the ocean as a tracer of anthropogenic $\mathrm{CO}_{2}$ uptake, Global Biogeochemical Cycles, 17(1).

Sabine, C. L., and R. A. Feely (2001), Comparison of recent Indian Ocean anthropogenic $\mathrm{CO}_{2}$ estimates with a historical approach, Global Biogeochemical Cycles, 15(1), 31-42.

Sabine, C. L., R. A. Feely, Y. W. Watanabe, and M. Lamb (2004a), Temporal evolution of the North Pacific $\mathrm{CO}_{2}$ uptake rate, Journal of Oceanography, 60(1), 5-15.

Sabine, C. L., R. M. Key, K. M. Johnson, F. J. Millero, A. Poisson, J. L. Sarmiento, D. W. R. Wallace, and C. D. Winn (1999), Anthropogenic $\mathrm{CO}_{2}$ inventory of the Indian Ocean, Global Biogeochemical Cycles, 13(1), 179-198.

Sabine, C. L., R. A. Feely, R. M. Key, J. L. Bullister, F. J. Millero, K. Lee, T. H. Peng, B. Tilbrook, T. Ono, and C. S. Wong (2002), Distribution of anthropogenic $\mathrm{CO}_{2}$ in the Pacific Ocean, Global Biogeochemical Cycles, 16(4).

Sabine, C. L., et al. (2004b), The oceanic sink for anthropogenic $\mathrm{CO}_{2}$, Science, 305(5682), 367-371.

Touratier, F., and C. Goyet (2004a), Applying the new TrOCA approach to assess the distribution of anthropogenic $\mathrm{CO}_{2}$ in the Atlantic Ocean, Journal of Marine Systems, 46(1-4), 181-197.

Touratier, F., and C. Goyet (2004b), Definition, properties, and Atlantic Ocean distribution of the new tracer TrOCA, Journal of Marine Systems, 46(1-4), 169-179.

Touratier, F., C. Goyet, C. Coatanoan, and C. Andrie (2005), Assessments of anthropogenic $\mathrm{CO}_{2}$ distribution in the tropical Atlantic Ocean, Deep-Sea Research Part IOceanographic Research Papers, 52(12), 2275-2284.

Wallace, D. (1995), Monitoring global ocean carbon inventoriesRep., 54 pp, Ocean Observing System Development Panel, Texas A\&M University, College Station, TX.

Wallace, D. (2001), Storage and transport of excess $\mathrm{CO}_{2}$ in the ocean: The JGOFS/WOCE global $\mathrm{CO}_{2}$ survey, in Ocean Circulation and Climate, edited by $\mathrm{G}$. Siedler, J. Church and J. Gould, pp. 489-521, Academic Press, San Diego, CA.

Wanninkhof, R., S. C. Doney, T. H. Peng, J. L. Bullister, K. Lee, and R. A. Feely (1999), Comparison of methods to determine the anthropogenic $\mathrm{CO}_{2}$ invasion into the Atlantic Ocean, Tellus Series B-Chemical and Physical Meteorology, 51(2), 511-530. 
Wanninkhof, R., S. Doney, J. L. Bullister, N. Gruber, C. Sabine, R. Feely, G. C. Johnson, and F. J. Millero (2006a), Changes in inorganic carbon inventory in the Atlantic Ocean over the last decade, EOS Transactions, AGU, 87(36), Abstract OS52C-01.

Wanninkhof, R., et al. (2006b), Carbon Dioxide, Hydrographic, and Chemical Data Obtained During the R/V Ronald H. Brown Repeat Hydrography Cruise in the Atlantic Ocean: CLIVAR $\mathrm{CO}_{2}$ Section A16S_2005 (11 January - 24 February, 2005)Rep., 38 pp, Carbon Dioxide Information Analysis Center, Oak Ridge National Laboratory, U.S. Department of Energy, Oak Ridge, Tennessee (http://cdiac.ornl.gov/oceans/ndp 087/NDP-087.html).

Waugh, D. W., T. M. Hall, B. I. McNeil, R. Key, and R. J. Matear (2006), Anthropogenic $\mathrm{CO}_{2}$ in the oceans estimated using transit time distributions, Tellus Series B-Chemical and Physical Meteorology, 58(5), 376-389.

Weiss, R. F. (1970), The solubility of nitrogen, oxygen, and argon in water and seawater, Deep-Sea Research, 17, 721-735.

Zeebe, R. E., and D. A. Wolf-Gladrow (2001), $\mathrm{CO}_{2}$ in Seawater: Equilibrium, Kinetics, Isotopes, 346 pp., Elsevier Oceanography Series, Amsterdam.

Zeebe, R. E., and D. A. Wolf-Gladrow (2004), Carbon Dioxide System in Seawater, http://www.soest.hawaii.edu/oceanography/faculty/zeebe files/CO2 System in Seawate r/csys.htmlRep. 
Carbon Cycle Variability

\begin{tabular}{|c|c|c|c|c|c|}
\hline \multirow{2}{*}{ Method } & \multicolumn{5}{|c|}{ RMS } \\
\cline { 2 - 6 } & $\begin{array}{c}\text { mean } \\
(\mathbf{0 - 2 0 0 0 m )}\end{array}$ & $\begin{array}{c}\text { mean } \\
(\mathbf{2 0 0 - 2 0 0 0 m )}\end{array}$ & mode & $\begin{array}{c}\text { max } \\
(\mathbf{0 - 2 0 0 0 m )})\end{array}$ & $\begin{array}{c}\mathbf{m a x} \\
(\mathbf{2 0 0 - 2 0 0 0 m})\end{array}$ \\
\hline DIC output & 4.59 & 2.29 & 0.62 & 23.37 & 13.09 \\
\hline $\mathbf{\Delta C}^{*}$ & 1.88 & 1.22 & 0.27 & 14.16 & 6.51 \\
\hline MLR & 3.55 & 0.88 & 0.28 & 53.83 & 6.26 \\
\hline eMLR & 0.65 & 0.31 & 0.16 & 2.86 & 1.04 \\
\hline
\end{tabular}

Table 2.1: The mean, mode and maximum of model DIC RMS variability $(1 \sigma)$ in $\mu \mathrm{mol} / \mathrm{kg}$ for model DIC output and the $\Delta \mathrm{C}^{*}$, MLR, and eMLR techniques. $1 \sigma$ values are calculated using years $101-450$ of the 1000 year CSM1.4 control run extracted along the A16 transect. Mode and mean values are based on grid cell values. As the empirical estimates are not robust above $200 \mathrm{~m}$, the mean and maximum values for $200-2000 \mathrm{~m}$ are also given. The mode is representative of the deep ocean variability. 


\section{Comparison of Anthropogenic Techniques}

\begin{tabular}{|c|c|c|c|c|c|c|c|}
\hline \multirow{2}{*}{ Method } & \multicolumn{4}{|c|}{ Anthropogenic Increase } & \multicolumn{3}{|c|}{$\begin{array}{c}\text { RMS } \\
\text { (estimated-predicted) }\end{array}$} \\
\hline & $\begin{array}{c}\text { mean } \\
(0- \\
2000 \mathrm{~m})\end{array}$ & $\begin{array}{c}\text { mean } \\
(200- \\
2000 m)\end{array}$ & $\begin{array}{c}\max \\
(0- \\
2000 \mathrm{~m}) \\
\end{array}$ & $\begin{array}{c}\max \\
(200- \\
2000 m)\end{array}$ & $\begin{array}{l}\text { Whole } \\
\text { section }\end{array}$ & $\begin{array}{c}0- \\
2000 m\end{array}$ & $\begin{array}{c}200- \\
2000 m\end{array}$ \\
\hline $\begin{array}{l}\text { predicted } \\
\Delta C_{\text {anthro }}\end{array}$ & 5.48 & 3.02 & 15.22 & 12.75 & -- & -- & -- \\
\hline$\Delta \mathbf{C}^{*}$ & 4.71 & 3.11 & 20.43 & 15.78 & 2.24 & 2.36 & 1.58 \\
\hline $\begin{array}{c}\Delta C^{*} \text { using } \\
\mathrm{PO}_{4}\end{array}$ & 4.48 & 3.16 & 25.45 & 17.04 & 4.15 & 4.19 & 2.59 \\
\hline MLR & 9.01 & 3.29 & 96.93 & 32.43 & 12.50 & 13.49 & 5.04 \\
\hline eMLR & 6.51 & 2.76 & 24.89 & 11.64 & 3.21 & 3.60 & 1.50 \\
\hline
\end{tabular}

Table 2.2: The mean, mode, and maximum of the predicted model $\Delta C_{\text {anthro }}$ in $\mu \mathrm{mol} / \mathrm{kg}$ and the $\Delta C_{\text {anthro }}$ estimates in $\mu \mathrm{mol} / \mathrm{kg}$ calculated using the $\Delta C^{*}, \Delta C_{P O 4}^{*}$, MLR, and eMLR techniques. $\Delta C_{\text {anthro }}$ values are calculated for a $10 \mathrm{yr}$ period with an average atmospheric $\mathrm{CO}_{2}$ of $375 \mathrm{ppm}$ using mean monthly model output extracted along the A16 transect. The RMS error for each estimate relative to $\Delta C_{\text {anthro }}^{\text {predicte }}$ is also given. 


\section{MLR Parameters}

\begin{tabular}{|c|c|c|c|c|c|c|c|}
\hline & $r^{2}$ & RMSE & Intercept & $\boldsymbol{\theta}$ & $\mathbf{S}$ & $\mathrm{O}_{2}$ & $\mathrm{PO}_{4}$ \\
\hline time $_{0}$ & 0.9903 & 4.98 & $\begin{array}{c}400.39 \\
\pm 21.83\end{array}$ & $\begin{array}{l}-4.26 \\
\pm 0.10\end{array}$ & $\begin{array}{c}49.26 \\
\pm 0.58\end{array}$ & $\begin{array}{c}-0.23 \\
\pm 0.01\end{array}$ & $\begin{array}{c}77.22 \\
\pm 0.86\end{array}$ \\
\hline time $_{1}$ & 0.9854 & 5.81 & $\begin{array}{c}456.02 \\
\pm 25.76 \\
\end{array}$ & $\begin{array}{c}-3.36 \\
\pm 0.11 \\
\end{array}$ & $\begin{array}{c}47.75 \\
\pm 0.68 \\
\end{array}$ & $\begin{array}{c}-0.19 \\
\pm 0.01\end{array}$ & $\begin{array}{c}77.61 \\
\pm 1.02 \\
\end{array}$ \\
\hline
\end{tabular}

Table 2.3: The $r^{2}$ values, the root mean squared error (RMSE) in $\mu \mathrm{mol} / \mathrm{kg}$, the MLR parameters, and the parameter $1 \sigma$ errors for the MLR fits to model output at time ${ }_{0}\left(t_{0}\right)$ and time ${ }_{1}\left(t_{1}\right)$, where $\mathrm{t}_{1}-\mathrm{t}_{0}$ is a $10 \mathrm{yr}$ period with an average atmospheric $\mathrm{CO}_{2}$ of $375 \mathrm{ppm}$. 

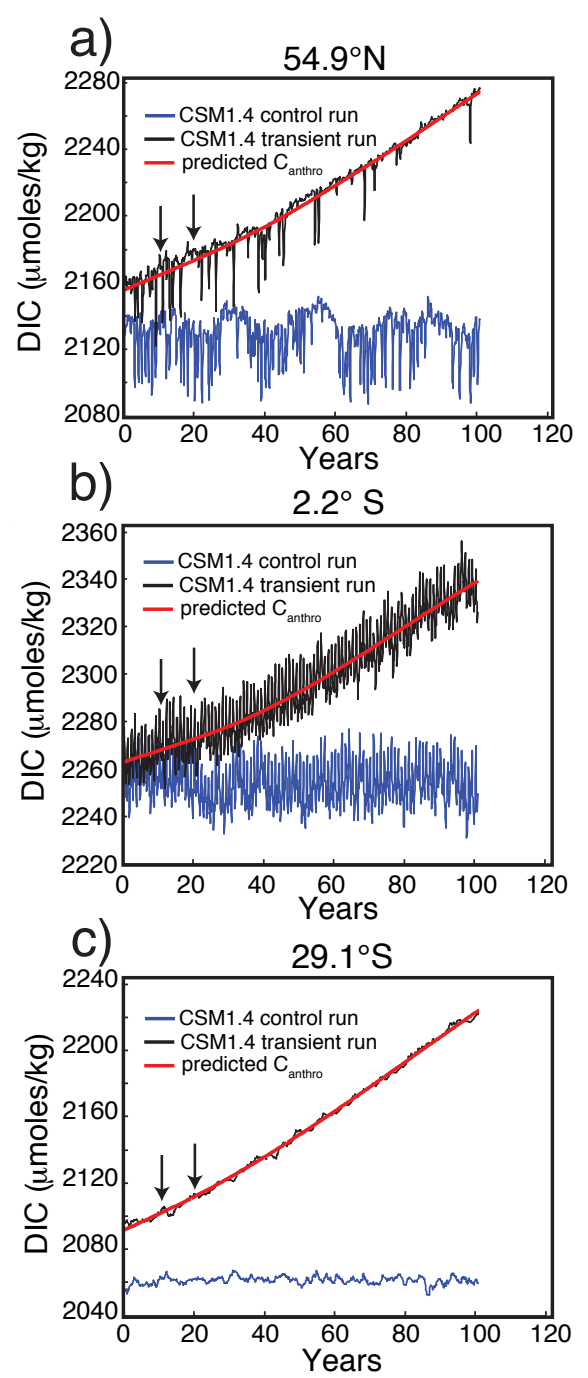

Figure 2.1: Time-series of CSM1.4 model output along the A16 transect at $245 \mathrm{~m}$ and (a) $54.9^{\circ} \mathrm{N}$, (b) $2.2^{\circ} \mathrm{S}$, and (c) $29.1^{\circ} \mathrm{S}$. The model output, with the drift removed, for control run years 280-380 is shown in blue, model output for the 'A2' transient run is shown in black, and the low-pass filter estimate of $\mathrm{C}_{\text {anthro }}$ is shown in red. Arrows indicate the times at which the model was sampled for the decadal analyses. 

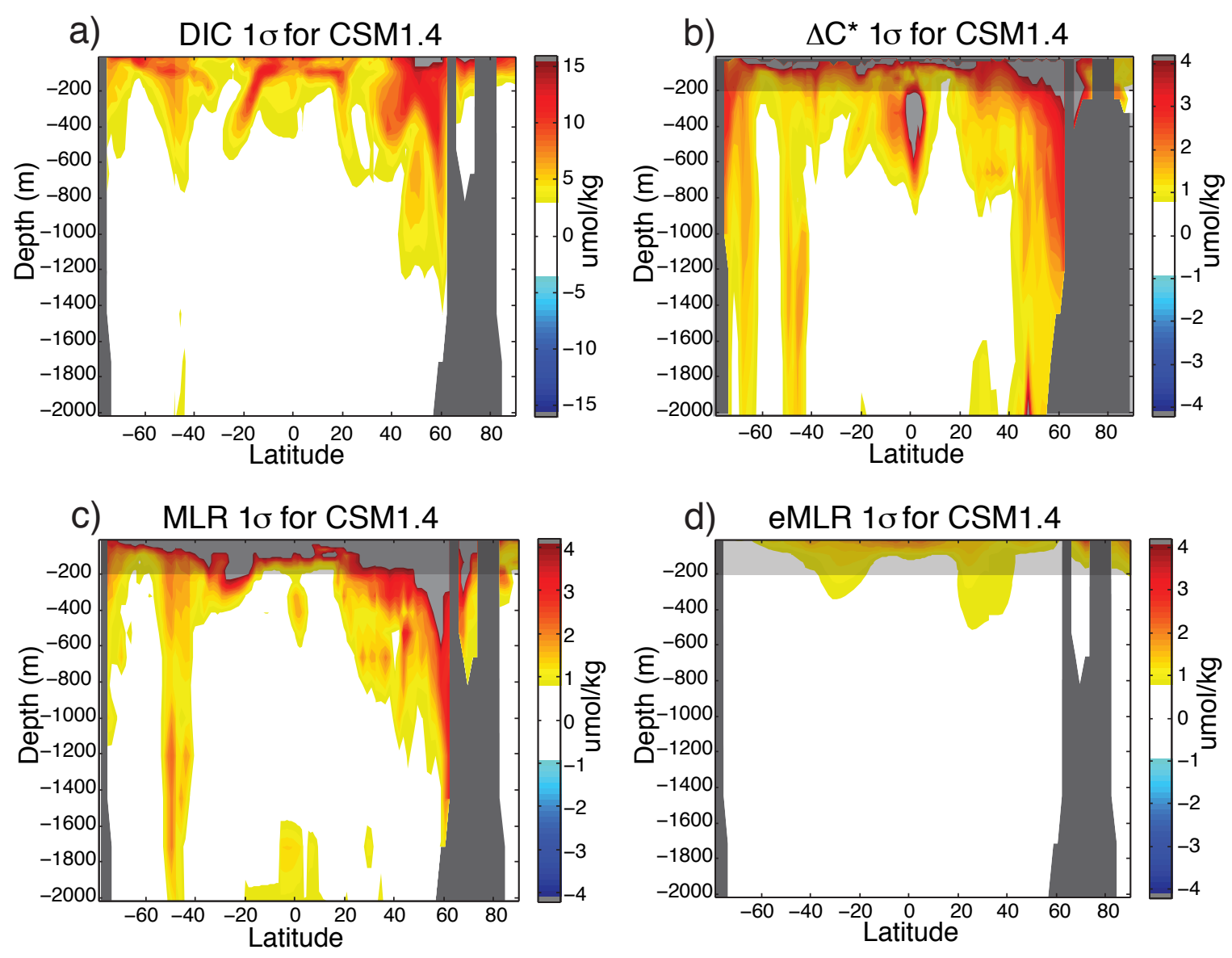

Figure 2.2: Depth profiles of CSM1.4 model output along the A16 transect showing RMS variability $(1 \sigma)$ for (a) model DIC output and (b) $\Delta C^{*}$, (c) MLR and (d) eMLR calculated using years $101-450$ of the 1000 year control run. $\Delta \mathrm{C}^{*}$ is calculated in isopycnal space and projected back into depth space. Note the difference in scale for panel (a). 

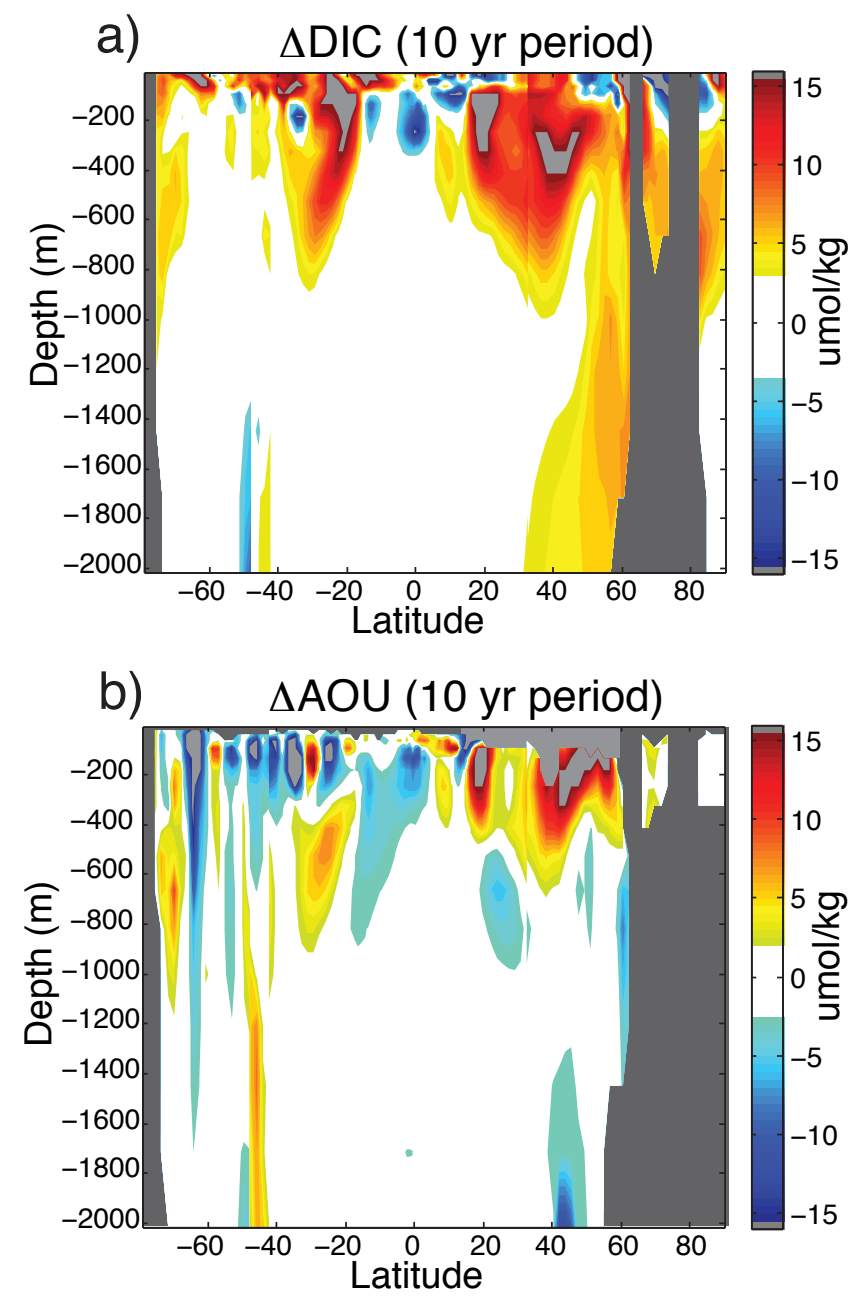

Figure 2.3: Depth profiles of CSM1.4 model output along the A16 transect showing (a) the 'snap-shot' change in DIC, and (b) the change in AOU for a 10 year period with an average atmospheric $\mathrm{CO}_{2}$ of $375 \mathrm{ppm}$. $\triangle \mathrm{AOU}$ is calculated in isopycnal space and projected back into depth space. 

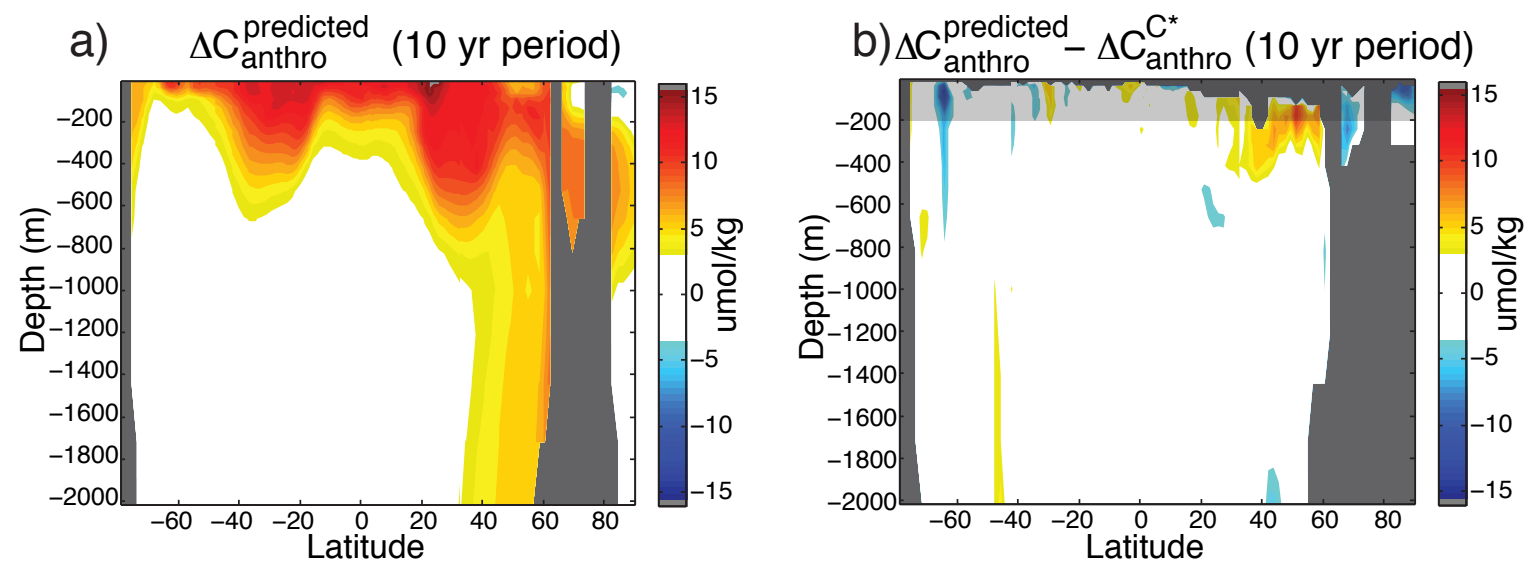

c) $\Delta C_{\text {anthro }}^{\text {predicted }}-\Delta C_{\text {anthro }}^{\mathrm{MLR}}(10 \mathrm{yr}$ period $)$

d) $\Delta C_{\text {anthro }}^{\text {predicted }}-\Delta C_{\text {anthro }}^{\text {eMLR }}(10$ yr period)
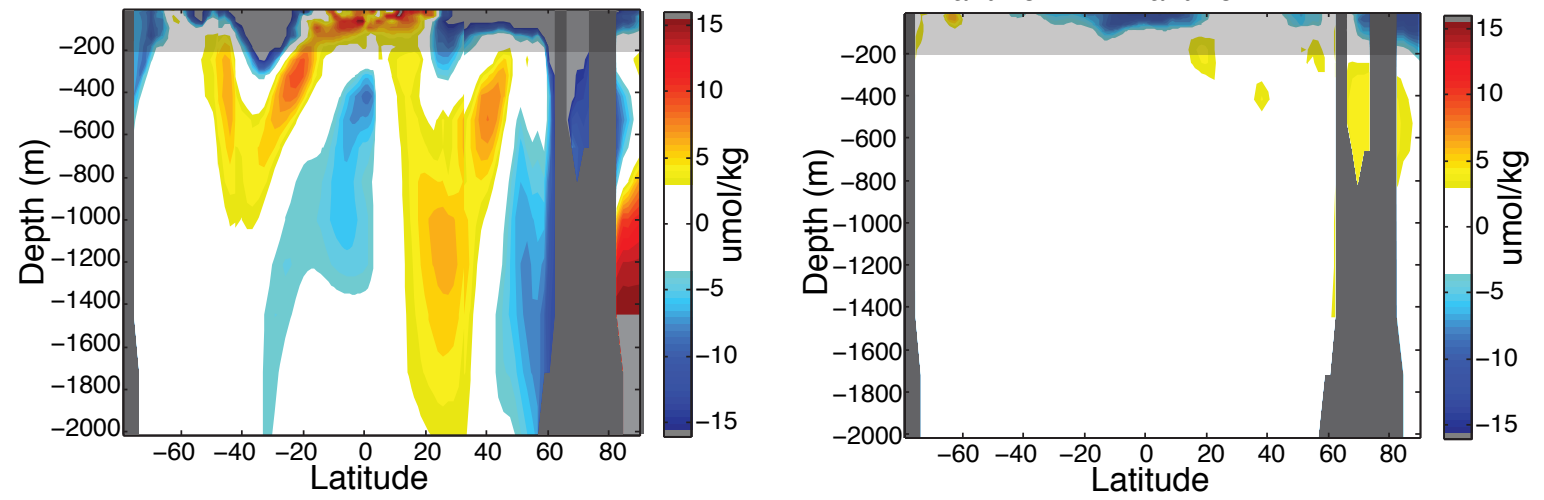

Figure 2.4: Depth profiles of CSM1.4 model output along the A16 transect showing a) $\Delta \mathrm{C}_{\text {anthro }}^{\text {predicted }}$ in $\mu \mathrm{mol} / \mathrm{kg}$ and the difference between $\Delta \mathrm{C}_{\text {anthro }}^{\text {predict }}$ and (b) $\Delta \mathrm{C}_{\text {anthro }}^{\mathrm{C}^{*}}$, (c) $\Delta \mathrm{C}_{\text {anthro, }}^{\mathrm{MLR}}$, and (d) $\Delta C_{\text {anthro }}^{\text {eMLR }}$ for a 10 year period with an average atmospheric $\mathrm{CO}_{2}$ of $375 \mathrm{ppm}$. $\Delta \mathrm{C}_{\text {anthro }}^{\mathrm{C}^{*}}$ is calculated in isopycnal space and projected back into depth space. The upper $200 \mathrm{~m}$ are shaded as the $\Delta \mathrm{C}_{\text {anthro }}$ estimates in this region are not robust. 


\section{Changes in Air-Sea Disequilibrium}

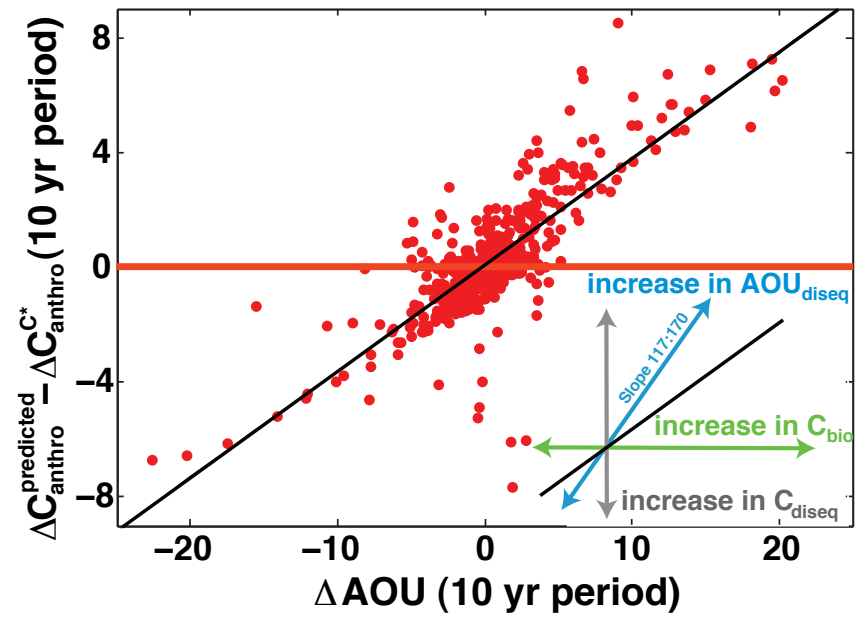

Figure 2.5: Correlation between model $\left(\Delta C_{\text {anthro }}^{\text {predicted }}\right.$ $\Delta \mathrm{C}_{\text {anthro }}^{\mathrm{C}^{*}}$ ) and $\Delta \mathrm{AOU}$, for a 10 year period with an average atmospheric $\mathrm{CO}_{2}$ of $375 \mathrm{ppm}$, caused by changes in airsea disequilibrium. Only data between 200-2000m and at the high latitudes $\left(40-70^{\circ} \mathrm{S}, 30-90^{\circ} \mathrm{N}\right)$ are displayed. $\Delta \mathrm{AOU}$ and $\Delta \mathrm{C}_{\text {anthro }}^{\mathrm{C}^{*}}$ are calculated in isopycnal space and projected back into depth space. If the $\Delta C^{*}$ method reproduced the predicted $\Delta \mathrm{C}_{\text {anthro }}$ signal exactly, the data points would all fall along the $\mathrm{x}$-axis, the red line. Since the $\Delta \mathrm{C}^{*}$ method accounts for changes in $\mathrm{C}_{\text {bio }}$, increases in $\mathrm{C}_{\text {bio }}$ simply move data points horizontally to the right, the green arrow. Deviations from the red line are caused by changes in $\mathrm{C}_{\text {diseq }}$ and $\mathrm{AOU}_{\text {diseq }}$ which move data points off the $\mathrm{x}$-axis vertically (grey arrow) and with a slope of $\mathrm{r}_{\mathrm{C}: \mathrm{AOU}}, 117: 170$ (the blue arrow), respectively. The best fit line is plotted in black and represents an amalgamation between changes in $\mathrm{AOU}_{\text {diseq }}$ and $\mathrm{C}_{\text {diseq }}$. 

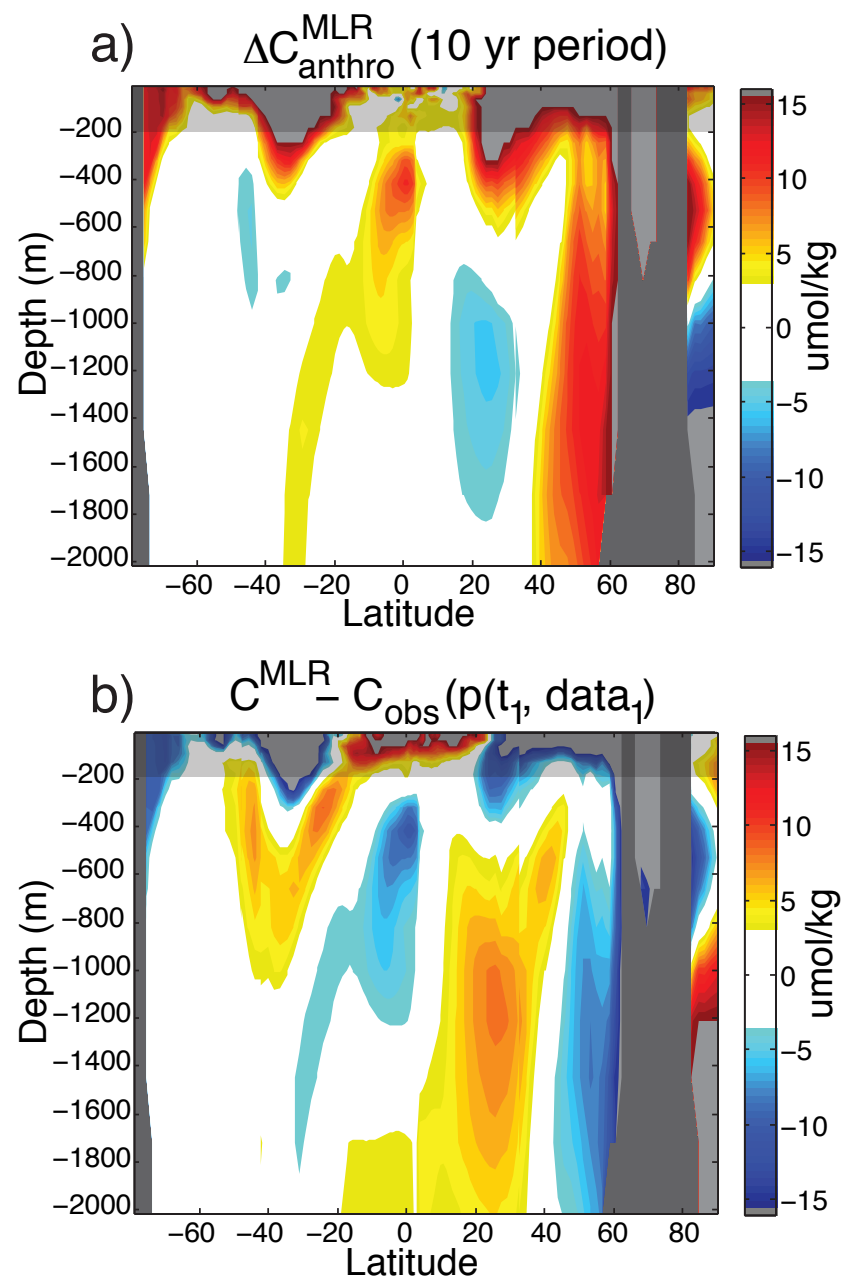

Figure 2.6: Depth profiles of CSM1.4 model output along the A16 transect showing (a) $\Delta \mathrm{C}_{\text {anthro }}$ calculated using the MLR technique for a 10 year period with an average atmospheric $\mathrm{CO}_{2}$ of $375 \mathrm{ppm}$, and (b) the model MLR residuals for time ${ }_{1}\left(\mathrm{t}_{1}\right)$. The upper $200 \mathrm{~m}$ are shaded as the $\Delta \mathrm{C}_{\text {anthro }}$ estimates in this region are not robust. 


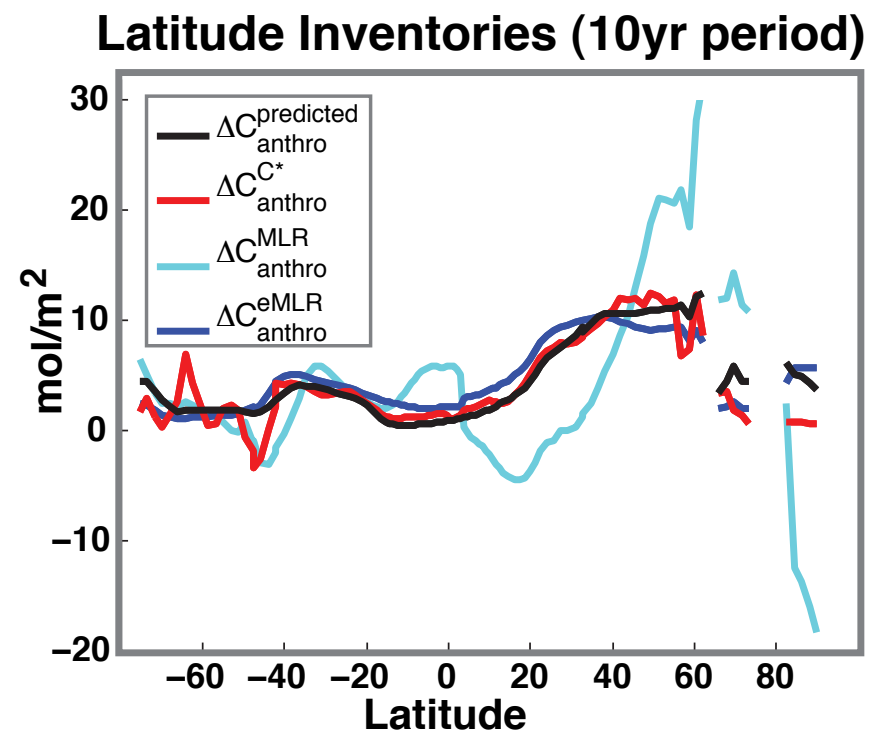

Figure 2.7: Comparison between predicted model column inventory $(200-2000 \mathrm{~m})$ of $\Delta \mathrm{C}_{\text {anthro }}$ and latitude inventories $(200-2000 \mathrm{~m})$ of $\Delta \mathrm{C}_{\text {anthro }}$ calculated using the $\Delta \mathrm{C}^{*}, \mathrm{MLR}$, and eMLR techniques for model output extracted along the A16 transect. Inventories are for a 10 year period with an average atmospheric $\mathrm{CO}_{2}$ of $375 \mathrm{ppm}$. 
a) DIC 1ofor CSM1.4

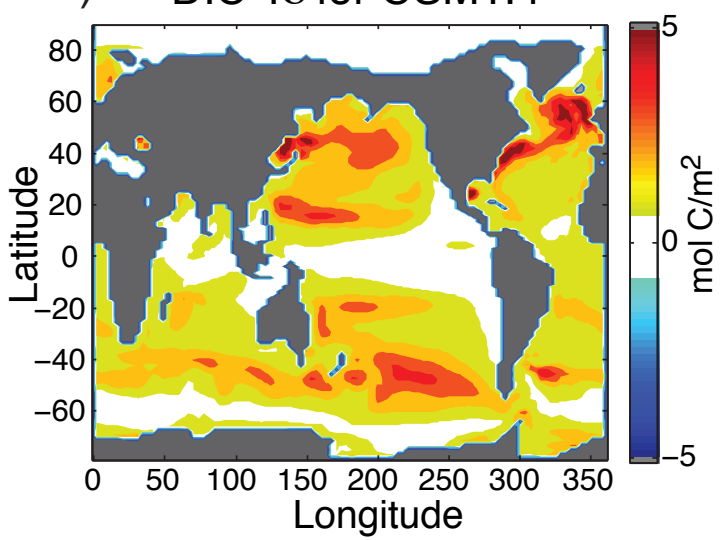

c) MLR 1o for CSM1.4

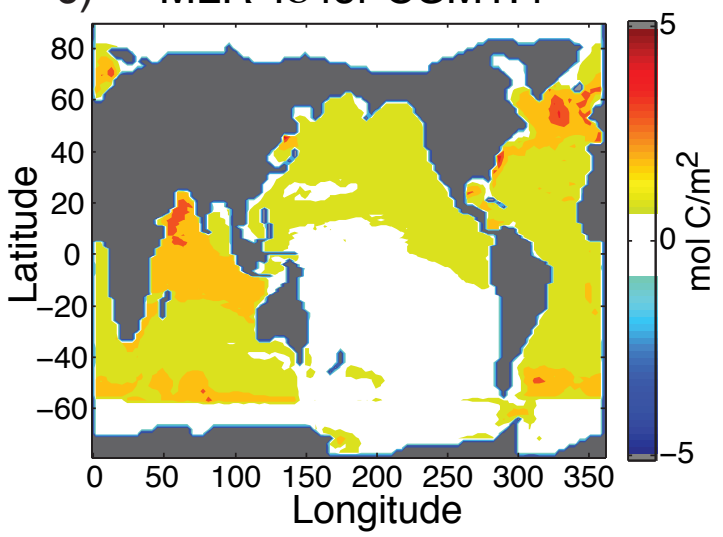

b) $\Delta C^{*} 1 \sigma$ for CSM1.4

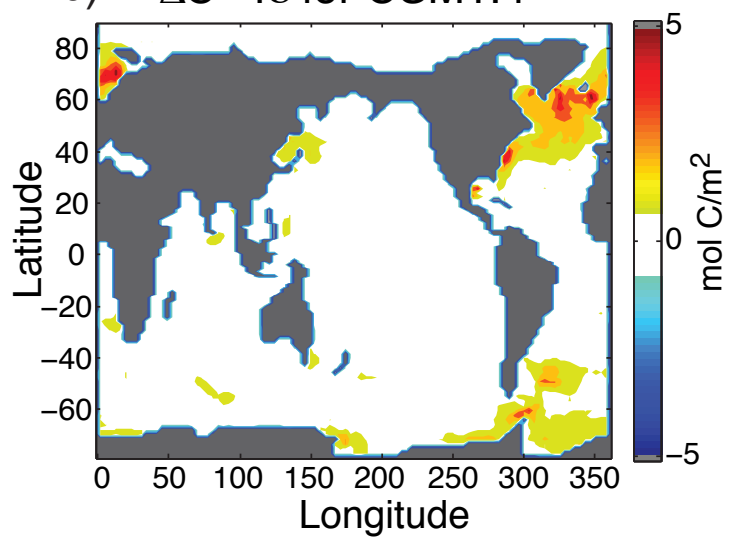

d) eMLR 1o for CSM1.4

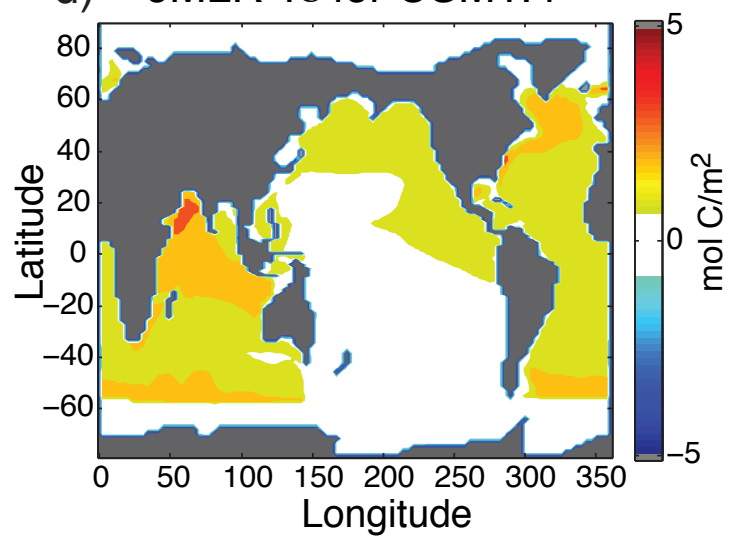

Figure 2.8: Spatial maps of CSM1.4 model output showing DIC column inventory (200-2000m) RMS variability ( $1 \sigma$ ) for (a) model DIC output and (b) $\Delta C^{*}$, (c) MLR and (d) eMLR calculated using years 101-450 of the 1000 year control run. 

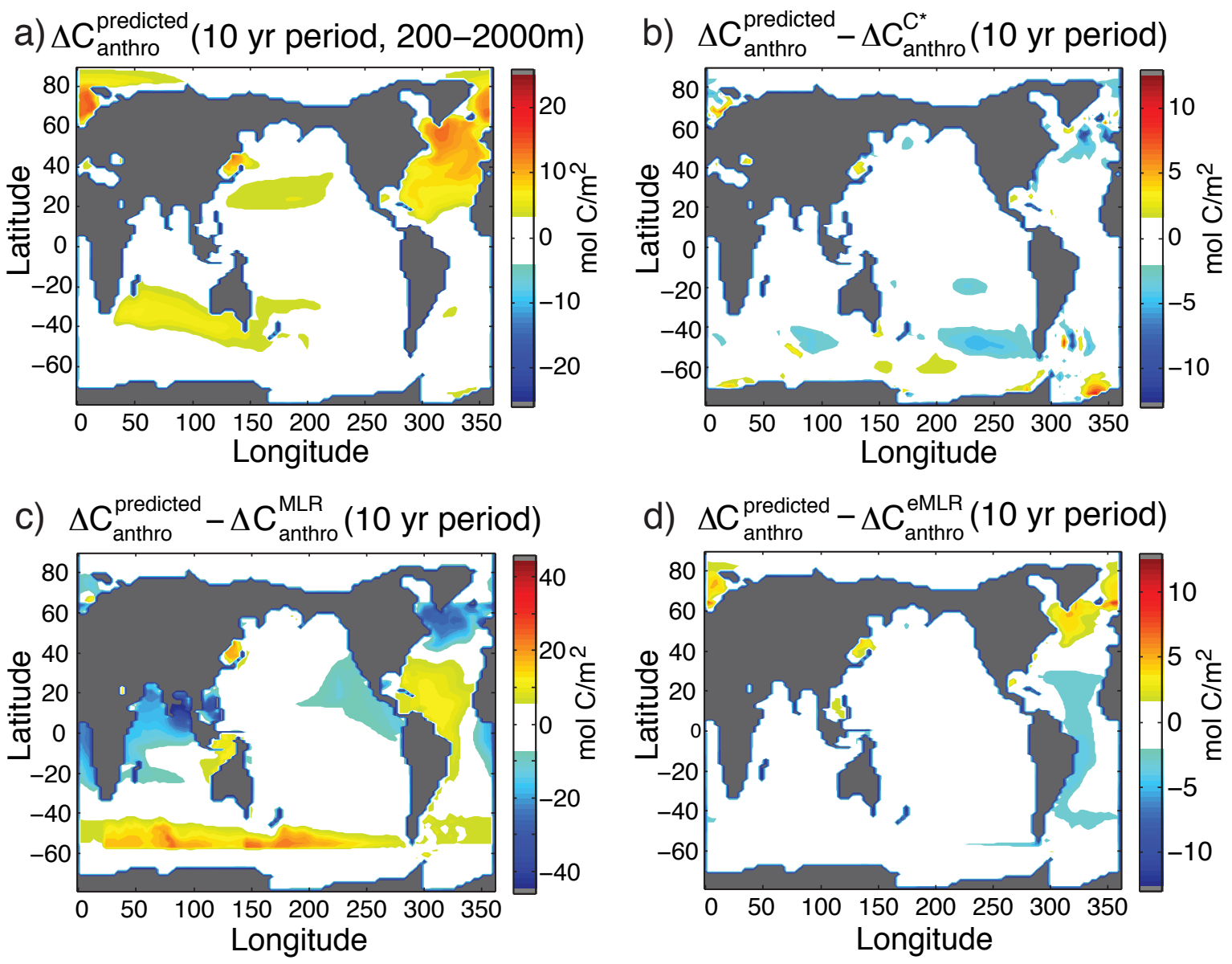

Figure 2.9: Spatial maps of CSM1.4 model output showing column inventories (200$2000 \mathrm{~m}$ ) in $\mathrm{mol} / \mathrm{m}^{2}$ of (a) $\Delta \mathrm{C}_{\text {anthro }}^{\text {predicted }}$ and the difference between $\Delta \mathrm{C}_{\text {anthro }}^{\text {predicted }}$ and (b) $\Delta \mathrm{C}_{\text {anthro }}^{\mathrm{C}^{*}}$, (c) $\Delta \mathrm{C}_{\text {anthro }}^{\mathrm{MLR}}$, and (d) $\Delta \mathrm{C}_{\text {anthro }}^{\mathrm{eML}}$ for a $10 \mathrm{yr}$ period with an average atmospheric $\mathrm{CO}_{2}$ of $375 \mathrm{ppm}$. Note the difference in scale for panels a and c. 
a)

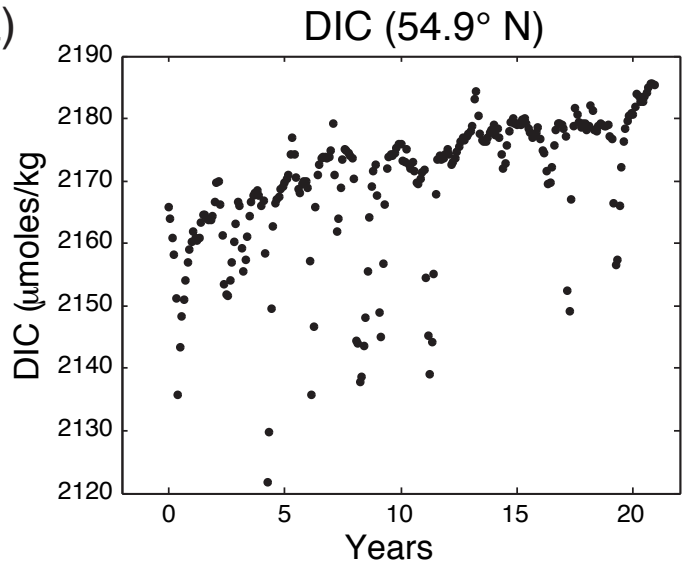

c)

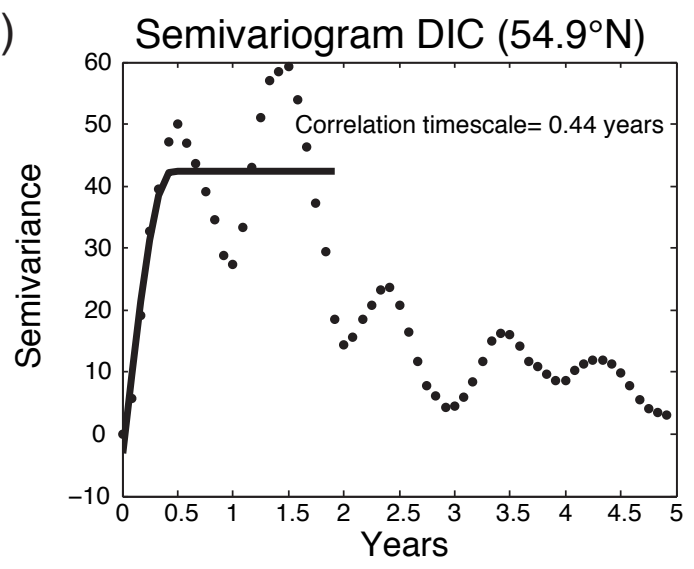

b) Fraction of Total Variance $\left(54.9^{\circ} \mathrm{N}\right)$

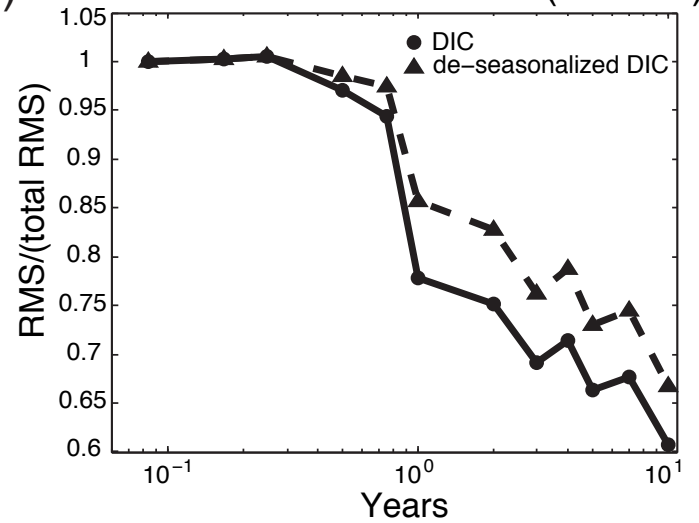

d)

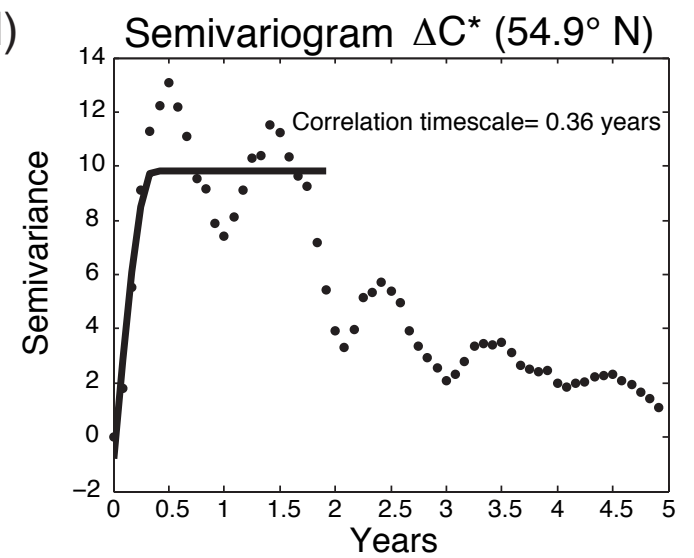

Figure 2.10: Correlation timescales for CSM1.4 model output along the A16 transect at $245 \mathrm{~m}$ and $54.9^{\circ} \mathrm{N}$. Panel a plots raw DIC data for a 20 year period with an average atmospheric CO of $375 \mathrm{ppm}$. Panels b, c, and d indicate the timescales on which data in this region become decorrelated. The fraction of total variance (b) compares the variability for a 10 year period captured by sub-sampling on timescales ranging from 2 months to 10 years to the total variability. The significant decrease in RMS/(total RMS) between 9 months and 1 year indicates that subanual sampling is necessary to capture the full variability in the system. The semivariance and best fit semivariogram of deseasonalized, de-trended DIC data (c) and $\Delta \mathrm{C}^{*}$ data (d) are also shown. The correlation timescales indicate the range over which samples are correlated $(0.44$ and 0.36 years respectively). 


\title{
Chapter 3:
}

\section{The Impact of Interannual Variability on the Uptake and Accumulation of Anthropogenic $\mathrm{CO}_{2}$ in the North Atlantic}

\begin{abstract}
The North Atlantic accounts for a significant portion of the global oceanic anthropogenic carbon sink. This basin experiences significant interannual variability primarily driven by the North Atlantic Oscillation (NAO). A suite of coupled numerical model simulations is used to analyze the impact of interannual variability on the uptake and storage of anthropogenic carbon $\left(C_{\text {anthro }}\right)$ in the North Atlantic. Regional differences are observed in the response of $C_{\text {anthro }}$ inventories to NAO forcing. Increases in subtropical and subpolar $C_{\text {anthro }}$ inventories correspond to increased mode water formation due to greater winter mixing during positive NAO years. Our analysis suggests that changes in mode water $C_{\text {anthro }}$ inventories are primarily due to water mass transformation rather than local air-sea $\mathrm{CO}_{2}$ exchange. This implies that much of the
\end{abstract}


anthropogenic carbon found in the ocean interior is from surface waters advected into the water mass formation region rather than from local gas exchange. Interannual variability in $C_{\text {anthro }}$ storage increases the difficulty of $C_{\text {anthro }}$ detection and attribution through hydrographic observations, which are biased by sparse sampling of subsurface waters in time and space.

\subsection{INTRODUCTION}

Since the industrial revolution, human activity has released large quantities of carbon dioxide $\left(\mathrm{CO}_{2}\right)$, which has resulted in increased atmospheric concentrations [e.g. Keeling and Whorf, 1994; Keeling et al., 1976]. However, the observed atmospheric increase accounts for only approximately half of anthropogenic carbon emissions [Canadell et al., 2007; Sabine et al., 2004]. The remaining anthropogenic $\mathrm{CO}_{2}$ has been taken up by the oceans and terrestrial biospheres, with approximately $30 \%$ of anthropogenic $\mathrm{CO}_{2}$ emissions being sequestered in the oceans [Sabine et al., 2004]. The future trajectory of atmospheric $\mathrm{CO}_{2}$, and the resulting impact on the global climate, is therefore dependent on the magnitude and stability of the ocean and terrestrial carbon sinks [Friedlingstein et al., 2006; Fung et al., 2005].

Over the past three decades, the oceanographic community has devoted significant time and resources to accurately detecting both the accumulation of anthropogenic carbon $\left(C_{\text {anthro }}\right)$ in the ocean and variability in the ocean carbon sink. Several global surveys of the ocean carbon system have been conducted including the Geochemical Ocean Section Study (GEOSECS) in the 1970s and the World Ocean Circulation Experiment (WOCE)/Joint Global Ocean Flux Study (JGOFS) surveys in the 
1990s. Currently, the US and International Climate Variability and Predictability (CLIVAR)/ $/ \mathrm{CO}_{2}$ program is continuing to monitor changes in ocean carbon by repeating key hydrographic surveys from the WOCE/JGOFS era. The thousands of high precision carbon observations made during these programs have provided a picture of the magnitude and variability of the ocean carbon sink. However, while significant headway has been made, the detection of $C_{a n t h r o}$ in the ocean still faces several major challenges.

The $C_{\text {anthro }}$ signal is superimposed on top of a large dissolved inorganic carbon (DIC) background, with $C_{\text {anthro }}$ accounting for only about $5 \%$ of DIC in surface waters in the 1990s [Sabine et al., 2004]. In addition, significant short term natural variability in the ocean carbon system makes the detection of relatively small, long-term temporal trends in $C_{\text {anthro }}$ difficult [Levine et al., 2008]. Several empirical methods have been proposed to deconvolve the $C_{\text {anthro }}$ signal from natural variability in the ocean carbon system [e.g. Friis et al., 2005; Gruber et al., 1996; Matsumoto and Gruber, 2005]. However, each of these methods has their own biases resulting in significant uncertainties in $C_{\text {anthro }}$ estimates particularly in regions of water mass formation [Levine et al., 2008; Vazquez-Rodriguez et al., 2009]. Finally, hydrographic cruises are expensive and provide limited temporal and spatial resolution.

The use of numerical models in conjunction with observations has become an invaluable tool for understanding the ocean carbon sink. Models provide increased spatial and temporal resolution in addition to insight into the underlying mechanisms controlling the uptake and accumulation of $C_{\text {anthro }}$ [e.g. Sarmiento et al., 1995]. This study uses the output of a global ocean model to investigate the impact of interannual 
variability on the uptake and storage of $C_{\text {anthro }}$ in the North Atlantic and to provide a context for observations of $C_{\text {anthro }}$ in this basin. Nearly $25 \%$ of anthropogenic carbon sequestered in the ocean is found in the North Atlantic, despite the fact that this basin only accounts for $15 \%$ of the global area [Sabine et al., 2004]. Changes in uptake and accumulation of carbon in this region therefore have the potential to significantly impact the global inventory. In addition, North Atlantic dynamics may be relevant to interannual variability in other ocean basins. Understanding the underlying mechanisms driving $C_{\text {anthro }}$ trends will also help improve models used to forecast future changes in atmospheric $\mathrm{CO}_{2}$ and global climate.

An important mechanism of $C_{\text {anthro }}$ sequestration in the North Atlantic is through the formation of deep and intermediate water in the subpolar gyre (e.g. North Atlantic Deep Water). These waters form during the winter and carry high $\mathrm{CO}_{2}$ water into the ocean interior where residence times range from decades to centuries [Wallace, 2001]. Subpolar mode waters (SPMW) form during deep winter mixing events in the subpolar gyre and are the dominant water mass above the permanent pycnocline [Brambilla and Talley, 2008; McCartney and Talley, 1982; L D Talley and McCartney, 1982]. Dense SPMW formed in the eastern subpolar gyre travels counter-clockwise around the gyre and into the Labrador Sea where some of it ultimately becomes part of the Labrador Sea Water (LSW), a component of North Atlantic Deep Water [Brambilla et al., 2008; McCartney and Talley, 1982; L D Talley and McCartney, 1982]. Hence, the properties of LSW are highly dependant on the properties and history of the densest SPMW [McCartney and Talley, 1982]. The formation of SPMW occurs primarily through water 
mass transformation (formation through diapycnal mixing and surface buoyancy flux) rather than through subduction (formation through water mass convergence) [Brambilla et al., 2008]. Therefore, wintertime mixed layer depths (MLD) play an important role in SPMW formation [Brambilla and Talley, 2008; J C Marshall et al., 1993; McCartney and Talley, 1982].

A number of studies have quantified changes in the subpolar ocean carbon sink based on observations of surface $\mathrm{pCO}_{2}$ [Corbiere et al., 2007; Lefevre et al., 2004; Omar and Olsen, 2006; Schuster and Watson, 2007] and profiles of DIC [Friis et al., 2005; Olsen et al., 2006; Perez et al., 2008]. The observed temporal rates of change of $\mathrm{CO}_{2}$ uptake and $\mathrm{C}_{\text {anthro }}$ accumulation, which range in different analyses and for different regions from an increase in the North Atlantic carbon sink to a decrease in the basin sink, are highly dependent on the time-period of observation (section 3.6.3). A modeling study by Thomas et al. [2008] proposes that changes in the dominant atmospheric climate mode (the North Atlantic Oscillation) have resulted in significant interannual variability in the subpolar and basin-scale air-sea $\mathrm{CO}_{2}$ flux. They further suggest that estimates of longterm trends from the limited observational records, which sample discrete time-periods, are potentially aliased by the sampling regime.

The circulation, heat transport and biogeochemical properties of subtropical gyres are driven primarily through the formation and transport of subtropical mode waters which fill in the region between the seasonal and permanent thermoclines [ $\mathrm{J}$ Marshall et al., 2009]. The primary subtropical mode water in the western North Atlantic is the Eighteen Degree Water (EDW), which forms south of the Gulf Stream during the winter 
months [e.g. L Talley and Raymer, 1982]. Variability in EDW formation and $\mathrm{CO}_{2}$ uptake has been shown to correlate to climate modes such as the North Atlantic Oscillation (NAO) [e.g. Bates, 2007; Bates et al., 2002; Gruber et al., 2002; Joyce et al., 2000]. However, the driving mechanisms behind these correlations remain unclear [Bates, 2007]. A summary of previous findings in the context of this study is presented in section 3.6.2.

Here we use a suite of model simulations to deconvolve the mechanisms driving interannual variability in the North Atlantic $C_{\text {anthro }}$ inventory in the subpolar and subtropical gyres. Shifts in the NAO, the primary climate mode in this region, result in deeper mixing in mode water formation regions in both gyres. This in turn increases the anthropogenic $\mathrm{CO}_{2}$ flux and rates of water mass transformation resulting in increased $C_{\text {anthro }}$ inventories along mode water isopycnals. The impact of NAO shifts on mode water $C_{\text {anthro }}$ inventories has implications for the future of the North Atlantic carbon sink as Intergovernmental Panel on Climate Change models predict an increased frequency of positive NAO years [Meehl et al., 2007].

\subsection{METHODS}

\subsubsection{Model Description}

The ocean Biogeochemical Element Cycle (BEC) component of the National Center for Atmospheric Research (NCAR) Community Climate System Model (CCSM3) is used for this study [Doney et al., 2009a; Doney et al., 2009b]. The model is non- 
eddy resolving with a grid spacing of $3.6^{\circ}$ longitude by $0.8^{\circ}-1.8^{\circ}$ latitude and 25 vertical levels. Mesoscale eddies are parameterized according to Gent and McWiliams [1990]. The model contains a full ecological module [Moore et al., 2004] with several phytoplankton function groups and multi-nutrient limitation including iron limitation. Fourteen components are included in the model: small/pico phytoplankton, large phytoplankton/diatoms, nitrogen fixing diazotrophs, zooplankton, suspended and sinking detritus, nitrate, ammonia, phosphate, iron, silicate, oxygen, DIC and alkalinity. The biogeochemistry module [Doney et al., 2006; Doney et al., 2009a] includes full carbonate system thermodynamics, $\mathrm{CO}_{2}$ air-sea gas exchange, a dynamic iron cycle, and dust deposition from an atmospheric transport model. Neither photosynthesis nor calcification is dependent on $\mathrm{CO}_{2}$ variables.

For this study, monthly model output from the following four model simulations are used:

- Transient $\mathrm{CO}_{2}$ Variable Physics: The model is integrated for a historical hindcast simulation from 1958-2004 forced with atmospheric reanalysis and satellite data products [Doney et al., 2007; Doney et al., 2009a]. Atmospheric $\mathrm{CO}_{2}$ is prescribed following observations.

- Pre-industrial $\mathrm{CO}_{2}$ Variable Physics: The model is integrated with the same forcing as Transient $\mathrm{CO}_{2}$ Variable Physics but atmospheric $\mathrm{CO}_{2}$ is fixed at preindustrial levels (280ppm).

- Transient $\mathrm{CO}_{2}$ Repeat Annual Year: The model is integrated with a repeating annual cycle of atmospheric state variables [Large and Yeager, 2004]. The 
'annual year' is constructed based on the most "average" year on record (1995) and maintains realistic high frequency forcings (e.g. storms) consistent with the climatological record. Atmospheric $\mathrm{CO}_{2}$ is prescribed following observations.

- Pre-industrial $\mathrm{CO}_{2}$ Repeat Annual Year: The model is integrated with the same forcing as Transient $\mathrm{CO}_{2}$ Repeat Annual Year but with atmospheric $\mathrm{CO}_{2}$ fixed at pre-industrial levels (280ppm).

For this study we focus on the period of 1970-2004 as these years show the greatest interannual variability in $C_{\text {anthro }}$ inventory and have available historical field observations.

\subsubsection{Calculations}

Anthropogenic carbon in the model is determined by subtracting the DIC concentration for paired model simulations with identical physics but with varying and constant atmospheric $\mathrm{CO}_{2}$ :

$$
C_{\text {anthro }}=D I C_{\text {Transient }}-D I C_{\text {Pre-industrial }}
$$

where $\mathrm{DIC}_{\text {Transient }}$ is the DIC concentration for the model pair with increasing atmospheric $\mathrm{CO}_{2}$ concentrations and $\mathrm{DIC}_{\text {Pre-industrial }}$ is the DIC concentration for the model pair with constant pre-industrial atmospheric $\mathrm{CO}_{2}$ concentrations. The impact of variable ocean physics is investigated by differencing $C_{\text {anthro }}$ for the 'Repeat Annual Year' model simulation from the 'Variable Physics' model simulation:

$$
\chi_{\text {anthro }}^{\text {physics }}=\chi_{\text {anthro }}^{\text {VariablePhysics }}-\chi_{\text {anthro }}^{\text {RepeatAnnualYear }}
$$


where $\chi_{\text {anthro }}^{\Delta \text { physics }}$ is the impact of variable physics on either $C_{\text {anthro }}$ concentrations $\left(C_{\text {anthro }}^{\Delta \text { physics }}\right)$ or $C_{\text {anthro }}$ inventory $\left(I_{\text {anthro }}^{\text {Aphsics }}\right)$, and $\chi_{\text {anthro }}^{\text {VariablePhysics }}$ and $\chi_{\text {anthro }}^{\text {RepantualYear }}$ are $C_{\text {anthro }}$ concentrations or inventories calculated using equation (1) for the Variable Physics and Repeat Annual Year model simulations, respectively. $C_{\text {anthro }}$ is given in $\mu \mathrm{mol} / \mathrm{kg}$. Unless otherwise specified, column inventories are calculated as the weighted sum of $C_{\text {anthro }}$ over the model thermocline (1280m to be precise based on the model vertical grid) and expressed in mol $\mathrm{C} / \mathrm{m}^{2}$. Isopycnal band column inventories are the weighted sum of $C_{\text {anthro }}$ over the thickness of the isopycnal band. Latitude band inventories are expressed in $\mathrm{Pg} \mathrm{C}$ and are calculated as the sum of the column inventories falling within a latitude band.

The monthly coefficient of variation for $I_{\text {anthro }}^{\text {sphyics }}$ is calculated as:

$$
\text { Coefficient of variation }=\frac{\sqrt{\frac{1}{N-1} \sum_{1}^{N}\left(\chi_{\text {anthro }}^{\text {VariablePhysics }}-\chi_{\text {anthro }}^{\text {RepeatAnnualYear }}\right)^{2}}}{\overline{\chi_{\text {anthro }}^{\text {RepeatAnnualYear }}}}
$$

where $\chi_{\text {anthro }}^{\text {VariablePhysics }}$ and $\chi_{\text {anthro }}^{\text {RepeatAnualYear }}$ are monthly concentrations or inventories of anthropogenic carbon, $\mathrm{N}$ is the number of months of output used to calculate the coefficient of variation (here we use monthly output for 1970-2004 so $\mathrm{N}=420$ ), and $\overline{\chi_{\text {anthro }}^{\text {RepeatAnualYear }}}$ is the mean value of $\chi_{\text {anthro }}^{\text {RepatAnualYear }}$ for the time period 1970-2004 where $\chi$ is either $C_{\text {anthro }}$ or $I_{\text {anthro }}$. Changes in carbon inventory with time are calculated as:

$$
\Delta I_{\text {anthro }}^{\Delta \text { physics }}=\left(I_{\text {anthro }}^{\text {physics }}\left(\operatorname{Dec}_{t 1}\right)-I_{\text {anthro }}^{\text {Dphysics }}\left(\operatorname{Dec}_{t 0}\right)\right) / 1 \text { year }
$$

where $\Delta I_{\text {anthro }}^{\text {pphyics }}$ is the change in $I_{\text {anthro }}$ over one year defined as December to December. This interval was chosen instead of the conventional January-January interval to allow for direct comparison with the NAO winter index, which is calculated for December-March. 
To evaluate the impact of interannual variability on the subtropical mode water (EDW), we focus on the wintertime EDW formation region and the $\sigma_{26.5}$ isopycnal surface. The EDW formation region is defined by the region where mean surface temperature (upper 50m) falls between $17.8^{\circ}$ and $18.4^{\circ} \mathrm{C}$ during the winter months (January-March) [after Bates et al., 2002]. The wintertime $\mathrm{CO}_{2}$ flux into the EDW formation region is calculated as the total net $\mathrm{CO}_{2}$ flux into the model ocean during January-March and is expressed in Pg C/yr. The $\sigma_{26.5}$ density band is defined as $26.25 \leq \sigma_{\theta} \leq 26.75$. The average depth for this density band in the subtropics $\left(15^{\circ}-40^{\circ} \mathrm{N}\right.$, $20^{\circ}-70^{\circ} \mathrm{W}$ ) is $218 \mathrm{~m}$ with a maximum depth of $381 \mathrm{~m}$, a mean thickness of $172 \mathrm{~m}$, and an average temperature of $18.0^{\circ} \mathrm{C}$. The subtropical $I_{\text {anthro }}$ for $\sigma_{26.5}$ is calculated as the sum of the column inventories across the $\sigma_{26.5}$ band for the area between $15^{\circ}-40^{\circ} \mathrm{N}$ and $20^{\circ}-70^{\circ} \mathrm{W}$ where $\sigma_{26.5}$ is deeper than $150 \mathrm{~m}$.

Our analysis of the interannual variability in the subpolar gyre focuses on the subpolar mode water (SPMW). For this study, we identify seven SPMW isopycnal bands, defined as; $27.3 \leq \sigma_{\theta}<27.4, \quad 27.4 \leq \sigma_{\theta}<27.5, \quad 27.5 \leq \sigma_{\theta}<27.55, \quad 27.55 \leq \sigma_{\theta}<27.6$, $27.6 \leq \sigma_{\theta}<27.65,27.65 \leq \sigma_{\theta}<27.675$, and $27.675 \leq \sigma_{\theta}<27.7$. Most of the analysis focuses on waters with $\sigma_{\theta}$ values between 27.6 and 27.7, which corresponds to the densest SPMW in the eastern basin [Brambilla and Talley, 2008]. In the Variable Physics model, the mean depth of the three densest SPMW bands in the subpolar gyre $\left(45^{\circ}-66^{\circ} \mathrm{N}, 57^{\circ} \mathrm{W}-18^{\circ} \mathrm{W}\right)$ are $518 \mathrm{~m}, 667 \mathrm{~m}$, and $778 \mathrm{~m}$ with a maximum depth of $815 \mathrm{~m}, 1113 \mathrm{~m}$, and $1113 \mathrm{~m}$ and mean thicknesses of $196 \mathrm{~m}, 212 \mathrm{~m}$, and $248 \mathrm{~m}$, respectively. The subpolar $I_{\text {anthro }}$ for the SPMW isopycnal surfaces are calculated as the sum of the column inventories across the 
individual SPMW isopycnal bands for the area between $45^{\circ}-66^{\circ} \mathrm{N}$ and $57^{\circ} \mathrm{W}-18^{\circ} \mathrm{W}$. The winter outcrop region for the densest SPMW is defined as the region where the $\sigma_{27.6-27.7}$ isopycnal band outcrops during the winter months (January-March). Since this work focuses on the North Atlantic, we limit our analysis to south of $70^{\circ} \mathrm{N}$. The wintertime uptake of anthropogenic $\mathrm{CO}_{2}$ by the $\sigma_{27.6-27.7} \mathrm{SPMW}$ is calculated as the sum of the net anthropogenic $\mathrm{CO}_{2}$ flux into the $\sigma_{27.6-27.7}$ winter outcrop region expressed in $\mathrm{Pg} \mathrm{C} / \mathrm{yr}$.

To deconvolve the dominant terms controlling changes in $\Delta I_{\text {anthro }}^{\Delta \text { phyics }}$, we partition the change in DIC into 5 components following Doney et al. [2007; 2009a]:

$$
d I_{D I C} \approx \int_{t}^{t+\Delta t}\left(F_{C O 2}^{\prime}+A_{D I C}^{\prime}+E_{D I C}^{\prime}+B_{D I C}^{\prime}+V_{D I C}^{\prime}\right) d t
$$

where $d I_{D I C}$ is the monthly change in DIC inventory in $\mathrm{mol} \mathrm{C} / \mathrm{m}^{2} / \mathrm{month}, \mathrm{F}_{\mathrm{CO} 2}$ is the change in the air-sea $\mathrm{CO}_{2}$ flux, $\mathrm{A}_{\text {DIC }}^{\prime}$ is the change in the vertical integral of the convergence of the resolved advective DIC transport, $\mathrm{E}_{\text {DIC }}$ is the change in the vertical integral of the convergence of the eddy-parameterized DIC transport, $\mathrm{B}^{\prime}{ }_{\text {DIC }}$ is the change in the vertical integral of net biological release of inorganic carbon, and $\mathrm{V}^{\prime}{ }_{\text {DIC }}$ is the change in the surface virtual flux of DIC due to freshwater fluxes. $\mathrm{F}_{\mathrm{CO} 2}^{\prime}, \mathrm{A}_{\mathrm{CO} 2}^{\prime}, \mathrm{E}_{\mathrm{CO} 2}$, $\mathrm{C}_{\mathrm{CO} 2}$, and $\mathrm{V}_{\mathrm{CO} 2}$ are integrated over a month such that the units for these terms are mol $\mathrm{C} / \mathrm{m}^{2} /$ month. $\mathrm{A}_{\mathrm{DIC}}$ is defined as:

$$
A_{D I C}=-\int_{0}^{1280} \nabla \cdot\left(\vec{v}_{r e s} D I C\right) d z
$$

where $\vec{v}_{\text {res }}$ is the resolved model velocity. The physical convergence terms and net biological release terms are integrated over the main thermocline $(1280 \mathrm{~m}$ based on the 
model vertical grid), and all terms are defined such that positive values result in an increase in DIC inventory.

To determine the terms responsible for monthly changes in $I_{\text {anthro }}$, we define $d I_{\text {anthro }}$ as:

$$
d I_{\text {anthro }}=d I_{\text {DIC }}^{\text {Transient }}-d I_{\text {DIC }}^{\text {Pre-industrial }}
$$

where $d I_{D I C}^{\text {Transient }}$ and $d I_{D I C}^{\text {Preindustrial }}$ are the monthly change in DIC inventory for the model pair with increasing atmospheric $\mathrm{CO}_{2}$ and constant atmospheric $\mathrm{CO}_{2}$, respectively. Equation (7) can be expanded using equation (5) to express $d I_{\text {anthro }}$ in terms of the 5 convergence and flux terms, hereafter collectively referred to as the terms of equation (5). Finally, we calculate $d I_{\text {anthro }}^{\Delta \text { phyics }}$ using equations (2), (5) and (7) in order to investigate the impact of changing ocean physics on the carbon terms. Following Doney et al. [2007; 2009a], we determine the dominant terms responsible for changes in $d I_{\text {anthro }}^{\text {pphsics }}$ by comparing the slopes of the 5 terms linearly regressed against $d I_{\text {anthro }}^{\text {Aphyss }}$. The dominant term will result in a regression slope close to 1 . Slopes greater than one indicate that the term is producing a larger anomaly than that observed in $d I_{\text {anthro }}^{\text {pphsics }}$. This anomaly is therefore being compensated by one (or more) of the other terms. Negative slopes indicate terms acting to dampen the impact of the dominant term(s).

\subsubsection{Model Bias}

The impact of changing physics on $C_{\text {anthro }}$ in the North Atlantic is evaluated using two separate model simulations, 'Repeat Annual Year' (RAY) and 'Variable Physics' 
(VP), described above (section 3.2.1). This analysis assumes an identical mean state for the two models, such that the mean rate of $C_{\text {anthro }}$ uptake for the two models is equivalent. While this appears to be the case for some regions (e.g. Appendix B panel a), in others there is a clear offset between the two model simulations (e.g. Appendix $B$ panel $b$ ) resulting from different forcing. The RAY forcing in Large and Yaeger [2004] was constructed to have balanced global heat and freshwater fluxes while retaining crosscorrelations in surface forcing terms on the synoptic or storm time-scale. It is not surprising that the mean ocean circulation state of RAY differs somewhat from the mean circulation in the VP integration given all of the potential non-linearities that can rectify variability in surface forcing into mixed layer depths, surface currents, etc. It is difficult to accurately correct for this bias, especially in regions of significant non-linear increases in $C_{\text {anthro }}$ and with substantial interdecadal variability. However, as this analysis focuses on interannual variability in the ocean system and not on long-term trends, differences in model mean state do not strongly impact our findings. A positive bias (when the mean $C_{\text {anthro }}$ accumulation of the VP simulation is greater than that of the RAY simulation) will result in a positive shift in $C_{\text {anthro }}^{\text {Aphsics }}$ values. However, correlations based on changes in interannual variability between the model simulations will not be impacted. Specifically, the impact of model bias on $d I_{\text {anthro }}^{\text {Aphyics }}$ and $\Delta I_{\text {anthro }}^{\text {sphyics }}$ will be minimal due to the short timescales of integration (one month- one year). 


\subsubsection{Sloshing and Heave}

The sloshing (horizontal shifts) of water masses, heave of isopycnal surfaces (vertical shifts), and shifts in gyre boundaries can all result in the apparent change in $I_{\text {anthro }}$ at a specific location. As discussed below, these changes are shown to contribute substantially to interannual variability in latitude band and point inventories and significantly impact trends in observations. To minimize the effects of sloshing and heave, we conduct much of our analysis along isopycnal surfaces. The $\sigma_{26.5}$ isopycnal band is used in the subtropics corresponding approximately to EDW, and bands between $\sigma_{27.3^{-}} \sigma_{27.7}$ are used in the subpolar gyre corresponding approximately to SPMW. Evaluating the role of variable physics on interannual variability along an isopycnal band eliminates the problem of isopycnal heave. Horizontal shifts in water mass boundaries will result in similar shifts in isopycnal surfaces. Therefore, integrating $I_{\text {anthro }}$ along the isopycnal surface over the entire gyre $\left(15^{\circ}-40^{\circ} \mathrm{N} 20^{\circ}-70^{\circ} \mathrm{W}\right.$ for the subtropical gyre and $45^{\circ}-66^{\circ} \mathrm{N} 57^{\circ}-18^{\circ} \mathrm{W}$ for the subpolar gyre) minimizes the impact of sloshing.

\subsubsection{Model Skill}

The CCSM BEC physical model was shown to accurately recreate to a substantial degree spatial and temporal trends in sea surface height, temperature, and circulation [Doney et al., 2007]. The spatial pattern and seasonal cycles of model air-sea $\mathrm{CO}_{2}$ flux and surface $\mathrm{pCO}_{2}$ also agree with global observations with an $\mathrm{RMS}$ error of 1.53 mol $\mathrm{CO}_{2}$ $\mathrm{m}^{-2} \mathrm{yr}^{-1}$ and $18.6 \mu \mathrm{atm}$, respectively [Doney et al., 2009b]. To evaluate model skill at 
reproducing $I_{\text {anthro }}$, the model output was extracted for the CLIVAR/CO $\mathrm{CO}_{2}$ north-south Atlantic hydrographic section (A16) for the year and months of the A16 occupations: February 1989 and December 2004 for the south Atlantic, and July-August 1993 and June-August 2003. As the model was only run through December 2004, this month was used for the second occupation of A16 south instead of the actual occupation dates, January-February 2005. Model $I_{\text {anthro }}$ for the A16 section was calculated following equation (1) and integrating over the upper $1280 \mathrm{~m}$. The decadal change in model $I_{\text {anthro }}$ in $\mathrm{mol} / \mathrm{m}^{2} /$ decade is compared to the observed $C_{\text {anthro }}$ inventory [Wanninkhof et al., in prep] in Figure 3.1. The variability estimate for the model $I_{\text {anthro }}$ is calculated as:

$$
\text { model variability }=\sqrt{\frac{1}{N-1} \sum\left(\Delta I_{\text {anthro }}^{10 y r}-\overline{I_{\text {anthro }}^{10 y r}}\right)^{2}}
$$

where $\Delta I_{\text {anthro }}^{10 y r}$ is the decadal change in $I_{\text {anthro }}$ for each month between January 1989 and December 2004 (i.e. January 1999- January 1989 to December 2004- December 1994), $\overline{\Delta I_{\text {anthro }}^{10 y r}}$ is the mean of the monthly decadal changes in $I_{\text {anthro }}$ from $1989-2004$, and $\mathrm{N}$ is the number of monthly $\Delta I_{\text {anthro }}^{10 y r}$ measurements $(\mathrm{N}=72)$. The model does a reasonable job reproducing the spatial pattern of $C_{\text {anthro }}$ uptake for the Atlantic section with an RMS error of $0.84 \mathrm{~mol} / \mathrm{m}^{2} / \mathrm{decade}$. The model is in good agreement with the observations for the subtropics and subpolar region, the focus of this study.

\subsubsection{North Atlantic Oscillation}

The North Atlantic Oscillation (NAO) is the major climate mode driving interannual variability in the North Atlantic [JW Hurrell, 1995]. The NAO has two 
phases, positive and negative. During positive NAO years, the combination of a strong atmospheric pressure low over Iceland and a strong atmospheric pressure high in the tropics results in increased storm frequency and current strength in the North Atlantic, Labrador and Nordic Seas [e.g. J Hurrell et al., 2003; J W Hurrell et al., 2001; Visbeck et al., 2003]. During a negative NAO, the Icelandic atmospheric low pressure system shifts southward resulting in more southerly storm tracks, fewer storms, and weaker currents in the North Atlantic [e.g. $J W$ Hurrell et al., 2001]. The shift from a negative to positive NAO has been shown to correlate with a northward migration of the Gulf Stream $[J$ Marshall et al., 2001] and changes in mixed layer depths [Carton et al., 2008; J Hurrell and Deser, 2009]. The strength of the NAO (the NAO index) is typically measured during the winter months, December- March. The past four decades have seen significant interannual variability in the NAO index, with the most prominent feature being an extended period of positive NAO from 1988 to 1995 . For this study we use the station-based wintertime NAO record for 1970-2004 compiled by James Hurrell (National Center for Atmospheric Research, Boulder CO USA, http://jisao.washington.edu/data sets/nao/). The BEC CCSM model response to NAO forcing is consistent with observed changes in circulation, vertical mixing, salinity and surface temperature [Thomas et al., 2008]. 


\subsection{INTERANNUAL VARIABILITY IN NORTH ATLANTIC $C_{A N T H R O}$ STORAGE}

Variable ocean physics results in seasonal, interannual, and decadal variability in North Atlantic $I_{\text {anthro, }}$, which is greatest on small scales and is dampened at larger scales (Figure 3.2). Individual model points for the VP simulation display monthly coefficients of variation (equation 3) ranging from $0.74 \%$ to $9.41 \%$ of the average RAY inventory for 1970-2004, with an average coefficient of variation of $2.16 \%$. Latitude band inventories show decreased high frequency variability with mean monthly coefficients of variation for the VP simulation ranging from $0.56 \%$ to $1.61 \%$ of the average RAY 1970-2004 inventory. The North Atlantic basin $I_{\text {anthro }}^{\text {VariablePhsics }}\left(15^{\circ}-70^{\circ} \mathrm{N}\right)$ has a monthly coefficient of variation of only $0.52 \%$ of the average RAY inventory. The different scales of variability suggest the importance of sloshing and heave, which impart large variations on small scales but do not impact the $I_{\text {anthro }}^{\text {Aphsics }}$ at larger scales. Interannual changes in basin $I_{\text {anthro }}^{\text {Aphyscs }}$ indicate that variable ocean physics only slightly impacts the uptake of anthropogenic $\mathrm{CO}_{2}$ by the North Atlantic basin as a whole (Figure 3.2a). However, changes in ocean forcing (e.g. increased frequency of positive NAO years) impacts the magnitude of regional carbon sinks in the North Atlantic particularly the storage of $C_{\text {anthro }}$ in mode waters (sections 3.4 and 3.5).

Another measure of interannual variability is changes in anthropogenic carbon accumulation rates. Anthropogenic carbon inventories increase with time in both the VP and RAY models. However, the inclusion of variable ocean physics in the VP model 
simulation results in both increases and decreases in $I_{\text {anthro }}$ accumulation rates relative to the RAY simulation. Latitude band $I_{\text {anthro }}^{\text {sphyics }}$ accumulation rates show significant interannual variability that varies both temporally and spatially. From January 1970 to December 2004, variable ocean physics resulted in an increase in all latitude band $I_{\text {anthro }}$ accumulation rates ranging from a $0.9 \%$ to a $4.4 \%$ increase, with the highest increase in the $50^{\circ}-60^{\circ} \mathrm{N}$ band. While this long-term increase in latitude $I_{\text {anthro }}$ may be due to model bias (see section 3.2.3), we assume that this bias results from a difference in mean model state and so all interannual variability is directly attributable to changes in model physics. $I_{\text {anthro }}$ accumulation rates show significant interannual variability with the change for a 5 year interval varying from a $36 \%$ decrease to a $38 \%$ increase in accumulation rate for the VP simulation as compared to the RAY simulation. A substantial portion of changes in latitude band $I_{\text {anthro }}^{\text {sphsics }}$ is due to water mass sloshing and isopycnal heave not due to changes in air-sea uptake rates. For example, the decrease in inventory between $20^{\circ}$ $30^{\circ} \mathrm{N}$ in the early $1990 \mathrm{~s}$ and subsequent increase in inventory between $30^{\circ}-40^{\circ} \mathrm{N}$ appears to be primarily due to a northward shift in the subtropical gyre boundary resulting from a transition to an extended positive NAO (discussed further below). These substantial changes in column inventories due to shifts in water mass boundaries increase the difficulty of detection and attribution of anthropogenic $\mathrm{CO}_{2}$ uptake with hydrographic observations, a challenge that may be addressable with models.

To minimize the impact of water mass sloshing and isopycnal heave, we analyze the change in $I_{\text {anthro }}^{\text {sphyics }}$ for isopycnal bands in the subtropics $\left(\sigma_{26.5}\right)$ and subpolar $\left(\sigma_{27.3}-\sigma_{27.7}\right)$ gyres. In the subtropics, variable ocean physics has resulted in significant interannual 
variability on the $\sigma_{26.5}$ surface (Figure $3.3 a$ ) with increased $C_{\text {anthro }}$ accumulation rates in the VP simulation of up to $106 \%$ for particular 5 year intervals. Similarly, the densest SPMW isopycnal bands, $\sigma_{27.55-27.7}$, show substantial interannual variability in $I_{\text {anthro }}^{\text {Aphsics }}$ with the largest increases on the $\sigma_{27.675-27.7}$ surface (Figure 3.3b). The $C_{\text {anthro }}$ accumulation rates for $\sigma_{27.675-27.7}$ were on average two times higher, and up to 100 fold higher, in the VP simulation for particular 5 year intervals as compared to the RAY simulation. The $I_{\text {anthro }}^{\text {Aphyics }}$ for the subtropical isopycnal band and several subpolar bands appear to be impacted by model bias (differences in the mean state of the VP versus RAY model), with $\sigma_{26.5}, \quad \sigma_{27.55-27.6}$ and $\sigma_{27.65-27.675}$ showing a negative bias and $\sigma_{27.675-27.7}$ showing a positive bias. As discussed above, the interannual variability in $I_{\text {anthro }}^{\text {Aphsics }}$ is not impacted by this bias. Therefore, $\Delta I_{\text {anthro }}^{\text {sphsics }}$ should reflect changes in uptake and accumulation of $C_{\text {anthro }}$ along the isopycnal surface. However, due to the potential for different biases along different SPMW surfaces, it is necessary to evaluate the density bands individually rather than as a cumulative inventory. For this study we focus on the $\sigma_{27.675-27.7}$ isopycnal surface. In the following sections, we investigate the mechanisms responsible for the interannual variability in $C_{\text {anthro }}$ uptake and storage in the subtropical (section 3.4) and subpolar (section 3.5) gyres and discuss the implication of these changes on $C_{\text {anthro }}$ observations (section 3.6) and for the future of the North Atlantic carbon inventory (section 3.7). 


\subsection{MECHANISMS GOVERNING INTERANNUAL VARIABILITY IN THE SUBTROPICAL GYRE}

The eighteen degree mode water (EDW) is the primary water mass in the North Atlantic subtropical thermocline. Therefore, variability in EDW formation and $C_{\text {anthro }}$ storage should account for a significant fraction of the interannual variability in the subtropical thermocline $(<1000 \mathrm{~m})$. In the RAY model simulation, EDW forms in the wintertime (January- March) between $35^{\circ}-38^{\circ} \mathrm{N}$. The formation region has a spatial average maximum mixed layer depth (MLD) of $292 \mathrm{~m} \pm 1(1 \sigma)$ and a spatial average wintertime mean MLD of $166 \mathrm{~m} \pm 6(1 \sigma)$. When variable ocean physics is included in the model (VP simulation), the spatial average maximum MLD of the EDW formation region increases to $337 \mathrm{~m} \pm 31(1 \sigma)$ and the average wintertime mean MLD increases to $171 \mathrm{~m}$ $\pm 20(1 \sigma)$ (Figure 3.4a). In addition, during the time-period under consideration (19702004), the location of the outcrop region in the VP model oscillates between $33^{\circ} \mathrm{N}$ and $40^{\circ} \mathrm{N}$. The northward extent of the EDW formation region determines the area of the outcrop, with polewards shift in the northern boundary resulting in periods of increased outcrop area. As expected, a larger outcrop footprint results in an increased anthropogenic $\mathrm{CO}_{2}$ flux into the EDW (Figure 3.5a). The uptake of anthropogenic $\mathrm{CO}_{2}$ is also impacted by the MLD of the formation region, with increased MLDs in individual model cells resulting in an increased uptake of $C_{\text {anthro }}$ in those cells (Figure 3.5b). Therefore, a northward shift in the EDW formation region results in greater EDW formation rates (thicker EDW isopycnal band) and consequentially an increased uptake of $C_{\text {anthro }}$ due to both greater formation rates and to deeper MLDs. 
As the EDW formation region is located directly south of the Gulf Stream, poleward shifts in the Gulf Stream and subtropical/subpolar boundary will result in a subsequent northward shift in the EDW formation region. Positive NAO years have been shown to result in such a northward shift of the Gulf Stream by approximately 1 degree [Joyce et al., 2000]. In the VP model, a positive NAO year generally results in a similar northward shift in the EDW formation region by a little over 1 degree. There is also a positive relationship between the NAO wintertime index and the mean EDW MLD, and the NAO index and the flux of anthropogenic $\mathrm{CO}_{2}$ into the EDW formation region (Table $3.1)$.

In the ocean interior, model EDW corresponds to a potential density anomaly of $\sigma_{\theta}$ of approximately 26.5. Bates et al. [2002] use a potential density anomaly of 26.4, however, in the model the EDW surface appears to be closer to 26.5. The seasonal evolution of $C_{\text {anthro }}$ along this isopycnal surface for a representative year (1993) is shown in Figure 3.6. During the winter months, anthropogenic carbon is injected onto the $\sigma_{26.5}$ surface just south of $40^{\circ} \mathrm{N}$, corresponding to the location of the EDW formation region. There appears to be a secondary ventilation site in the eastern subtropical gyre. These high $C_{\text {anthro }}$ signals are then transported clockwise around the gyre. By September, the high $C_{\text {anthro }}$ signals have been dispersed throughout the eastern and southern portion of the subtropical gyre. Figure 3.6 aliases in changes in isopycnal thickness, which will act to decrease isopycnal $I_{\text {anthro }}$ (thinning of the isopycnal band) or increase isopycnal $I_{\text {anthro }}$ (thickening of the isopycnal band). However, changes in isopycnal thickness will not impact the total $\sigma_{26.5}$ inventory when integrated over the subtropical gyre. 
Using equations (5)-(7), we evaluate the primary terms responsible for changes in

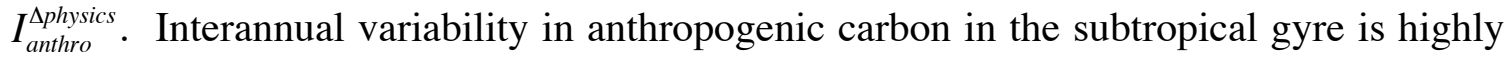
correlated with changes in advective convergence, in particular with the horizontal convergence of carbon (Figure 3.7). This is consistent with previous work, which showed that interannual changes in DIC and temperature in the subtropics are dominated by advective transport [Doney et al., 2007; Doney et al., 2009a]. This analysis suggests that most of the changes in $I_{\text {anthro }}$ observed in the gyre interior are due to $C_{\text {anthro }}$ anomalies and changes in isopycnal thickness advected from outcrop regions where large scale mixing events and $\mathrm{CO}_{2}$ air-sea fluxes occur.

Changes in EDW wintertime $\mathrm{CO}_{2}$ air-sea flux (smoothed with a three year running mean) is positively correlated with changes in $\sigma_{26.5}$ gyre inventory $\left(\Delta I_{\text {anthro } \sigma_{26.5}}^{\Delta \text { physi }}\right)$ with a lag of 1 year (slope $9.94 \pm 4.65$, r value 0.36 , p value 0.043 ). However, changes in the EDW formation region $\mathrm{CO}_{2}$ air-sea flux only accounts for approximately $10 \%$ of the change in $\Delta I_{\text {anthro }_{26.5}}^{\text {Aphsis }}$ (not shown). As discussed previously, the air-sea $\mathrm{CO}_{2}$ flux into the EDW outcrop region is highly correlated with the EDW wintertime footprint, which is also related to the mean MLD in the formation region. Variability in the wintertime EDW footprint and MLD will also impact rates of water mass transformation, which forms EDW during wintertime mixing events through diapycnal mixing and surface water transformations via air-sea buoyancy fluxes. Therefore, we believe that the

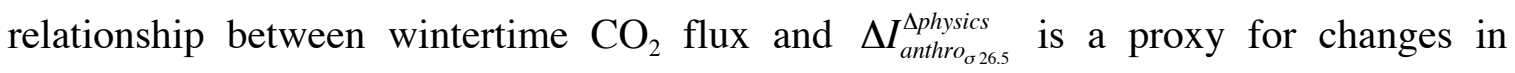
$\Delta I_{\text {anthro }_{026.5}}^{\text {sphyirs }}$ driven by changes in rates of water mass transformation. This is consistent 
with the findings of Alfultis and Cornillon [2001], who suggest that overlying waters are entrained into the EDW during wintertime mixing events. Once subducted into the gyre interior, these high $C_{\text {anthro }}$ waters are transported clockwise around the subtropical gyre. The relationship between changes in the EDW formation region and shifts in the NAO index, as reflected by changes in $\Delta I_{\text {anthro }_{026.5}}^{\Delta \text { phyics }}$, is such that positive NAO years correspond to increases in $\Delta I_{\text {anthro }_{026.5}}^{\text {sphsics }}$ (Table 3.1). This transfer of $C_{\text {anthro }}$ from surface waters to the EDW through water mass transformation acts can sequester the anthropogenic carbon for years to a few decades (the approximate residence time of interior water in the subtropical gyre [Jenkins, 1998; Robbins and Jenkins, 1998]). This consequently increases the magnitude of the subtropical $C_{\text {anthro }}$ sink over these time-scales. Changes in rates of mode water re-ventilation to the atmosphere may decrease or increase the timescale of sequestration [e.g. Bates et al., 2002].

\subsection{MECHANISMS GOVERNING INTERANNUAL VARIABILITY}

\section{IN THE SUBPOLAR GYRE}

Variability in subsurface $I_{\text {anthro }}$ in the subpolar gyre is primarily driven by changes along the densest SPMW, $\sigma_{27.55-27.7}$ (not shown). Here we focus on the mechanisms driving interannual variability along the $\sigma_{27.675-27.7}$ isopycnal surface, which is most likely a precursor for LSW [McCartney and Talley, 1982; L D Talley and McCartney, 1982]. In the subpolar gyre, variability in the simulated mean winter MLD is significantly correlated with the NAO index such that the model mean winter MLD in the subpolar 
gyre is greater during positive NAO years than during negative NAO years (Figure 3.8a, Table 3.1). Deep winter mixed layers during positive NAO years correspond both to increased anthropogenic $\mathrm{CO}_{2}$ flux into the subpolar gyre (Figure 3.9) and to increased ventilation of dense SPMW isopycnal surfaces (as defined by the intersection of the winter mixed layer with the isopycnal band). This results in a greater $\mathrm{CO}_{2}$ flux onto the $\sigma_{27.5-27.7}$ isopycnal surfaces during positive NAO years as compared to negative NAO years (Figure 3.10). These findings are consistent with previous modeling studies which show that positive NAO years correlate with increased deep and intermediate water formation [Lohmann et al., 2009] and increased air-sea $\mathrm{CO}_{2}$ fluxes [Thomas et al., 2008].

In the winter months, the outcrop region for the dense SPMW in the VP model, $\sigma_{27.6-27.7}$, occurs between $54^{\circ}-66^{\circ} \mathrm{N}$ and has a spatial average monthly mean MLD of $327 \mathrm{~m} \pm 53 \mathrm{~m}$ (Figure $3.4 \mathrm{~b}$ ) and a spatially averaged maximum wintertime MLD of $1035 \mathrm{~m} \pm 153 \mathrm{~m}$. The air-sea $\mathrm{CO}_{2}$ flux into this outcrop region is compared to the change in inventory for the $\sigma_{26.675-27.7}$ surface and the NAO index in Figure 3.8b. While the flux into $\sigma_{27.6-27.7}$ is positively correlated with $\Delta I_{\text {anthro }}^{\text {Aphsics }}$ for $\sigma_{27.675-27.7}$ (slope 5.6 $\pm 1.8, \mathrm{r}$ value $0.49, \mathrm{p}$ value 0.004 ), the local anthropogenic $\mathrm{CO}_{2}$ air-sea flux only accounts for approximately $10 \%$ of the change in $I_{\text {anthro }}^{\text {Aphyics }}$ (Figure $3.8 b$ ). Similarly, an analysis of the primary budget terms responsible for changes in $I_{\text {anthro }}^{\text {sphsics }}$ (equations (5)-(7)) shows that only $\sim 10 \%$ of changes in $d I_{\text {anthro }}^{\Delta \text { physcs }}$ are due to gas exchange (Figure 3.11). As in the subtropics, the majority of $d I_{\text {anthro }}^{\Delta \text { shyscs }}$ variability is due to changes in advective DIC convergence. However, in the subpolar gyre, this relationship is driven by large changes in the horizontal advective carbon convergence that is compensated by similarly large, but 
inversely related, changes in the vertical advective carbon convergence. Part of this relationship may be explained by net mass convergence that is compensated by downwelling.

Similar to the EDW, this analysis indicates that $C_{\text {anthro }}$ storage in SPMW is primarily driven by water mass transformations rather than by local air-sea $\mathrm{CO}_{2}$ gas exchange. This is consistent with the conclusions of Omar and Olsen [2006] from hydrographic observations that the change in subpolar surface $\mathrm{pCO}_{2}$ concentrations are primarily driven by changes in surface water $\mathrm{pCO}_{2}$ advected into the subpolar gyre. This is illustrated in Figure 3.12 using model output. Deep winter mixing homogenizes the upper water column redistributing the anthropogenic carbon, decreasing surface $C_{\text {anthro }}$ and increasing $C_{\text {anthro }}$ at depth (Figure 3.12b). The resulting increased $C_{\text {anthro }}$ in the gyre interior persists after the mixing event (Figure 3.12c). During the summer and early fall, anthropogenic carbon concentrations build back up in surface waters (Figure 3.12a, $d$ ), most likely due to advective transport of high anthropogenic $\mathrm{CO}_{2}$ subtropical water, and the cycle repeats. Evidence for northward transport of high $C_{\text {anthro }}$ surface waters is found both in hydrographic observations [e.g. Alvarez et al., 2004; Alvarez et al., 2003; Holfort et al., 1998; Macdonald et al., 2003; Omar and Olsen, 2006] and in numerical inversion studies [e.g. Holfort et al., 1998; Mikaloff Fletcher et al., 2006]. In particular, modeling work by Mikaloff Fletcher et al. [2006] find a northward $C_{\text {anthro }}$ transport into the subtropical gyre of $0.12 \pm 0.01 \mathrm{Pg} \mathrm{C} / \mathrm{yr}$ and a transport of $0.02 \pm 0.01 \mathrm{Pg} \mathrm{C} / \mathrm{yr}$ into the subpolar gyre. Similarly, Holfort et al. [1998] and Alvarez et al. [2003] conclude that the majority of $C_{\text {anthro }}$ stored in the North Atlantic is advected into this region by northward 
flowing surface waters. Specifically, Alvarez et al. [2003] estimate that $C_{\text {anthro }}$ rich surface waters are advected into the subpolar gyre at a rate of $0.044 \pm 0.047 \mathrm{Pg} \mathrm{C} / \mathrm{yr}$.

Increased $I_{\text {anthro }}$ in the dense SPMW has significant implications for the North Atlantic carbon sink. As McCartney and Talley [1982, pg 1186] write, "Because the Labrador Sea Water is the last, densest variety of Subpolar Mode Water, its properties depend on the entire history of the Subpolar Mode Water as it is advected cyclonically around the subpolar North Atlantic, including the path history of air-sea and lateral heat exchange." Therefore, increased $I_{\text {anthro }}$ in SPMW translates into increased $I_{\text {anthro }}$ in LSW, which acts to sequester anthropogenic carbon on the timescale of up to several decades [Haine et al., 2003; L D Talley and McCartney, 1982; Waugh et al., 2004]. Alvarez et al. [2004] conclude that the net southward flow of the LSW is the largest contributor to the transport of $C_{\text {anthro }}$ from the subpolar region into the subtropics. However, the long term impact of increased SPMW $I_{\text {anthro }}$ may be dampened by re-ventilation of SPMW $C_{a n t h r o}$. Modeling work by Haine et al. [2003] suggests that $60 \%$ of waters subducted in the subpolar North Atlantic are re-ventilated to the atmosphere after 6-8 years.

\subsection{IMPLICATIONS FOR OBSERVATIONS}

Numerous observations have been made in an attempt to constrain the patterns, rates, and temporal evolution of the North Atlantic carbon sink by measuring both air-sea $\mathrm{CO}_{2}$ fluxes and changes in subsurface carbon inventory. These measurements work synergistically with model analysis; observations provide an important check of model 
output, and model results provide a context for interpreting observations and insight into the mechanisms driving interannual variability in observed $I_{\text {anthro }}$.

\subsubsection{Anthropogenic carbon versus total carbon}

In the model, we are able to easily separate anthropogenic and natural carbon. Therefore, in the above analysis, we are able to focus on the response of anthropogenic carbon uptake and storage to variable ocean physics. However, there is no simple way to differentiate between these two carbon pools in oceanographic observations. In general, observational estimates of anthropogenic carbon accumulation rates rely on either the use of empirical methods (discussed in section 3.1) or on long term monitoring of total carbon. The latter approach assumes a steady state ocean such that any long term trends in total carbon or air-sea $\mathrm{CO}_{2}$ flux can be attributed to anthropogenic carbon uptake. The accuracy of this approach can be improved by correcting for changes in salinity, dissolved oxygen, and nutrient concentrations. However, recent modeling studies show that long term trends in anthropogenic air-sea $\mathrm{CO}_{2}$ flux can be inversely related to changes in the natural air-sea $\mathrm{CO}_{2}$ flux [Lovenduski et al., 2008]. Our analysis demonstrates that, while changing model physics has resulted in a slight increase in anthropogenic carbon inventory in the North Atlantic basin between 1970-2004, variable model physics has caused total carbon (anthropogenic + natural) inventories to decrease over this time period (Figure 3.2a). Similarly, the impact of changing model physics on mean anthropogenic carbon concentrations for the EDW and SPMW isopycnal bands is not correlated or slightly negatively correlated with the impact of physics on the mean 
total carbon inventory for these water masses (Figure 3.13). The inverse relationship between total DIC ${ }^{\Delta p h y s i c s}$ and anthropogenic carbon ${ }^{\text {sphysics }}$ is most likely due to spatial differences in the vertical and horizontal concentration gradients of these two pools. This differential response of natural and anthropogenic carbon to variable ocean physics makes observations of changes in the ocean carbon sink substantially more difficult [e.g Lovenduski et al., 2008]. Below we compare our numerical modeling results to

observations of changes in subtropical and subpolar $I_{\text {anthro }}$. While we find good agreement between the observations and model predictions, it is important to keep in mind that the observations may alias changes in natural carbon that we have not addressed in the model analysis.

\subsubsection{Subtropical gyre}

Bates et al. [2002] report increases in EDW DIC concentrations at the Bermuda Atlantic Time-series Study (BATS) site that are twice the expected rate based on the atmospheric increase for the period of 1988-2001. This corresponds to an increased carbon uptake of 0.03-0.25 Pg C/yr. Similarly, Bates [2007] finds an increased carbon sink for the subtropics between 1983-2004. These authors attribute the increased subtropical carbon sink to weakening wind speeds and reduced mixing events at BATS, which act to decrease ventilation of EDW $C_{\text {anthro }}$ back to the atmosphere. Decreased mixing also increases the residence time of EDW thereby decreasing dissolve oxygen concentrations and increasing DIC due to remineralization. Bates et al. [2002] conclude that the increases in remineralized DIC due to increased EDW residence times are small 
relative to changes in air-sea $\mathrm{CO}_{2}$ flux. Gruber et al. [2002] also correlate variability in winter MLD, sea surface temperature and DIC at BATS with shifts in the NAO phase..

The model simulations described above are consistent with the findings of Bates et al. [2002], Gruber et al. [2002] and Bates [2007]. Model mean yearly MLDs and mean wintertime MLDs near Bermuda are lower for the period from 1988-2004 as compared to 1970-1987, though this difference is not statistically significant in the model output. In addition, $I_{\text {anthro }}$ on the EDW isopycnal surface is elevated in the model between 1990-1999. Finally, as discussed above, the southern extent of the simulated EDW outcrop oscillates between $33^{\circ} \mathrm{N}$ and $36^{\circ} \mathrm{N}$ in relation to the NAO phase such that the southern extent of the outcrop is closest to the BATS site during negative NAO years. This is consistent with the findings of Bates et al. [2002] that EDW formation at BATS decreases during a positive NAO phase. However, based on the spatial and temporal resolution of the model, we are able to propose an additional mechanism for the observed increase in the subtropical carbon sink during positive NAO years, e.g. 1988-1997. In the model, increased mixing and a larger EDW wintertime outcrop footprint during positive NAO years results in increased mode water formation. A thicker EDW isopycnal surface acts to sequester more anthropogenic carbon in the gyre interior. This results in increases in EDW $C_{\text {anthro }}$ storage similar to that observed by Bates et al. [2002].

The response of EDW formation to positive NAO forcing in the model is consistent with the findings of Joyce et al. [2000] and Alfultis and Cornillon [2001]. An analysis of hydrographic data indicates large spatial and temporal variations in EDW renewal events with the outcrop region varying between $30^{\circ}-40^{\circ} \mathrm{N}$ [Alfultis and 
Cornillon, 2001], a similar range to that observed in the model (Figure 3.4a). However, these authors do not suggest a mechanism for the observed variability in EDW renewal events. Joyce et al. [2000] find a high degree of correlation between positive NAO years, the northward extent of the Gulf Stream, and the thickness of the EDW (or potential vorticity of the EDW) near Bermuda. They conclude that the northward migration of the Gulf Stream in response to positive NAO forcing controls the formation of EDW in the Sargasso Sea.

The model analysis presented in section 3.4 supports the conclusion that the subtropics respond to NAO atmospheric forcing with a lag of 1-2 years, consistent with observational studies showing the presence of an ocean memory [Curry and McCartney, 2001]. Taylor and Stephens [1998] find that the northern extent of the Gulf Stream lags the NAO index by 2-3 years and Joyce et al. [2000] report a 0-1 year lag for the same response. However, Joyce et al. [2000] use a slightly different NAO index which decreases the lag response time [Curry and McCartney, 2001]. Gonzalez-Davila et al. [2007] find a similar lagged response of 3 years for the eastern subtropics to NAO forcing.

\subsubsection{Subpolar gyre}

A number of studies have evaluated changes in the North Atlantic subpolar carbon sink over the past four decades. Pérez et al. [2008] use a suite of hydrographic cruises in the subpolar gyre to evaluate the change in $C_{\text {anthro }}$ storage in this region between 1981 and 2006. They report high rates of $C_{\text {anthro }}$ uptake and storage in the early 1990's 
and decreasing rates of storage from 1997-2006. Similarly, Friis et al. [2005] find high rates of subpolar anthropogenic carbon accumulation between 1981-1997. A number of studies evaluate changes in surface $\mathrm{pCO}_{2}$ and air-sea gas exchange in the subpolar gyre [Corbiere et al., 2007; Lefevre et al., 2004; Olsen et al., 2006; Schuster and Watson, 2007; Schuster et al., 2009]. The observational time period for most of these studies span from the early 1990's (period of high positive NAO) into the early 2000's (period of neutral or negative NAO). For this observational window, researchers have concluded that the North Atlantic carbon sink is decreasing, but this trend may not be robust when considered in the context of interannual to decadal variability that can be aliased into trend estimates for short time-periods [Schuster et al., 2009; Thomas et al., 2008]. When the observational window is expanded, the measured changes in $\mathrm{pCO}_{2}$ and air-sea gas exchange are consistent with each other, with the estimates of $C_{\text {anthro }}$ storage [Perez et al.,

2008] and with our model analysis, which shows increased $C_{\text {anthro }}$ uptake and storage during positive NAO years and decreased uptake during negative NAO years. This highlights the importance of an understanding of interannual variability in the interpretation of hydrographic observations.

\subsection{DISCUSSIONS AND CONCLUSIONS}

Interannual variability impacts the anthropogenic carbon inventory of the North Atlantic. In both the subtropical and subpolar gyres, increased $C_{\text {anthro }}$ uptake occurs as a result of increased mode water formation and air-sea $\mathrm{CO}_{2}$ exchange during the winter 
months (sections 4 and 5). Changes in the frequency, duration and intensity of mode water formation events are related to shifts in wind stress, circulation patterns and winter storms associated in part with shifts in the North Atlantic Oscillation. In our model simulations, positive NAO years correspond to increased $\Delta I_{\text {anthro }}^{\Delta \text { physics }}$ in both the subpolar and subtropical gyres (Figure $3.14 b, d, f$ ). Increases in $\Delta I_{\text {anthro }}^{\Delta \text { phsics }}$ during positive NAO years correspond to increased MLDs in the subpolar gyre immediately following the NAO shift and persisting for a year after the event (Figure 3.14a-d). Our analysis suggests that the increase in subpolar $I_{\text {anthro }}^{\text {Aphsics }}$ during positive NAO years is due to increased water mass transformation during SPMW mode water formation.

The subtropics show an initial decrease in MLD and increase in $\Delta I_{\text {anthro }}^{\text {Aphysics }}$ in response to a positive NAO. This change in MLD is consistent with the observations of Bates et al. [2002] (see above discussion) and could explain the initial increase in subtropical $\Delta I_{\text {anthro }}^{\Delta \text { phyics }}$ increased $\Delta I_{\text {anthro }}^{\Delta \text { physics }}$ due to decreased re-ventilation of $C_{\text {anthro }}$ back to the atmosphere. Changes in latitude band $I_{\text {anthro }}^{\text {sphysc }}$ also suggest that some water mass sloshing occurs in the subtropics in response to shifts in the NAO phase (Figure 3.2b). The band of negative correlation between the NAO index and $\Delta I_{\text {anthro }}^{\text {Aphyss }}$ found south of the subtropical band of positive correlation supports the possibility of water mass sloshing. Changes in subtropical mode water formation region MLDs lag 1-2 years behind an NAO shift, at which point a positive relationship between the MLDs in the subtropics and the NAO index is observed. $I_{\text {anthro }}^{\text {Aphyics }}$ in the subtropical gyre also shows a positive relationship 
to NAO with a lag of two years. We suggest that some of this correlation may be due to changes in EDW $I_{\text {anthro }}$ resulting from changes in formation rates and EDW thickness.

In both gyres, changes in local anthropogenic air-sea $\mathrm{CO}_{2}$ flux into mode waters account for only $\sim 10 \%$ of changes in mode water $I_{\text {anthro }}^{\text {pphyss }}$. We conclude that mode water $\Delta I_{\text {anthro }}^{\Delta \text { physc }}$ is primarily driven by water mass transformation in which light, high $C_{\text {anthro }}$ surface waters are entrained onto deeper isopycnal surfaces through diapycnal mixing and surface buoyancy heat flux. This implies that much of the anthropogenic carbon found in the ocean interior is from surface waters advected into the water mass formation region rather than from local gas exchange. As discussed above, previous work suggests a significant northward transport of surface currents carrying high anthropogenic carbon waters from the tropics into the subtropics and onward into the subpolar gyre. Holfort et al. [1998] further suggest a significant cross-hemisphere transport of surface waters with a net flux of $C_{\text {anthro }}$ from the South Atlantic into the North Atlantic. Therefore, the anthropogenic carbon sequestered in North Atlantic mode waters most likely derives from air-sea $\mathrm{CO}_{2}$ flux into tropical and subtropical waters, potentially in the South Atlantic basin.

Our findings also suggest that climate modes, such as the NAO, can alter the residence time of anthropogenic carbon in the ocean by altering the rate of water mass transformation that acts to transport surface $C_{\text {anthro }}$ into the ocean interior where it is sequestered for several years to several decades. In addition, increased frequency of positive NAO years, such as is predicted by IPCC modeling studies [Meehl et al., 2007], could increase the strength of the North Atlantic sink by increasing mode water 
formation. However, these changes may be reduced due to other climate feedbacks such as an increased freshwater flux in the Labrador and Nordic seas that may act to decrease deep water formation [e.g. Thorpe et al., 2001], or increased stratification in the subtropics resulting from secular increases in surface temperatures [e.g. Boyd and Doney, 2002; IPCC, 2001].

The observational estimates of subpolar $C_{\text {anthro }}$ uptake and storage highlights the difficulties of detection and attribution. Observations are easily biased by sampling strategy and the time-period of observations. In addition, it is difficult to parcel out observed inventory changes that are due to lateral sloshing and vertical heave from those resulting in varied uptake rates. Rodgers et al. [in press] suggest that altimetry data in conjunction with numerical models may help correct for some of the interannual variability in observed DIC concentrations. Similarly, we conclude that numerical models should be employed to provide both a context for hydrographic observations and an understanding of the driving mechanisms behind observed trends. 


\subsection{ACKNOWLEDGEMENTS}

We would like to acknowledge funding from NSF (OCE-0623034), NCAR, the WHOI Ocean Climate Institute, a National Defense Science and Engineering Graduate Fellowship and an Environmental Protection Agency STAR graduate fellowship. NCAR is sponsored by the National Science Foundation.

\subsection{REFERENCES}

Alfultis, M. A., and P. Cornillon (2001), Annual and interannual changes in the North Atlantic STMW layer properties, Journal of Physical Oceanography, 31(8), 2066-2086.

Alvarez, M., F. F. Perez, H. Bryden, and A. F. Rios (2004), Physical and biogeochemical transports structure in the North Atlantic subpolar gyre, Journal of Geophysical Research-Oceans, 109(C3).

Alvarez, M., A. F. Rios, F. F. Perez, H. L. Bryden, and G. Roson (2003), Transports and budgets of total inorganic carbon in the subpolar and temperate North Atlantic, Global Biogeochemical Cycles, 17(1).

Bates, N. R. (2007), Interannual variability of the oceanic CO2 sink in the subtropical gyre of the North Atlantic Ocean over the last 2 decades, Journal of Geophysical Research-Oceans, 112(C9).

Bates, N. R., A. C. Pequignet, R. J. Johnson, and N. Gruber (2002), A short-term sink for atmospheric $\mathrm{CO} 2$ in subtropical mode water of the North Atlantic Ocean, Nature, 420(6915), 489-493.

Boyd, P. W., and S. C. Doney (2002), Modeling regional responses by marine pelagic ecosystems to global climate change, Geophysical Research Letters, 29(16).

Brambilla, E., and L. D. Talley (2008), Subpolar Mode Water in the northeastern Atlantic: 1. Averaged properties and mean circulation, Journal of Geophysical ResearchOceans, 113(C4). 
Brambilla, E., L. D. Talley, and P. E. Robbins (2008), Subpolar Mode Water in the northeastern Atlantic: 2. Origin and transformation, Journal of Geophysical ResearchOceans, 113(C4).

Canadell, J. G., C. Le Quere, M. R. Raupach, C. B. Field, E. T. Buitenhuis, P. Ciais, T. J. Conway, N. P. Gillett, R. A. Houghton, and G. Marland (2007), Contributions to accelerating atmospheric $\mathrm{CO} 2$ growth from economic activity, carbon intensity, and efficiency of natural sinks, Proceedings of the National Academy of Sciences of the United States of America, 104(47), 18866-18870.

Carton, J. A., S. A. Grodsky, and H. Liu (2008), Variability of the oceanic mixed layer, 1960-2004, Journal of Climate, 21(5), 1029-1047.

Corbiere, A., N. Metzl, G. Reverdin, C. Brunet, and A. Takahashi (2007), Interannual and decadal variability of the oceanic carbon sink in the North Atlantic subpolar gyre, Tellus Series B-Chemical and Physical Meteorology, 59(2), 168-178.

Curry, R. G., and M. S. McCartney (2001), Ocean gyre circulation changes associated with the North Atlantic Oscillation, Journal of Physical Oceanography, 31(12), 33743400 .

Doney, S. C., K. Lindsay, I. Fung, and J. John (2006), Natural variability in a stable, 1000-yr global coupled climate-carbon cycle simulation, Journal of Climate, 19(13), 3033-3054.

Doney, S. C., S. Yeager, G. Danabasoglu, W. G. Large, and J. C. McWilliams (2007), Mechanisms governing interannual variability of upper-ocean temperature in a global ocean hindcast simulation, Journal of Physical Oceanography, 37(7), 1918-1938.

Doney, S. C., I. Lima, R. A. Feely, D. M. Glover, K. Lindsay, N. Mahowald, J. K. Moore, and R. Wanninkhof (2009a), Mechanisms governing interannual variability in upper-ocean inorganic carbon system and air-sea CO2 fluxes: Physical climate and atmospheric dust, Deep-Sea Research Part Ii-Topical Studies in Oceanography, 56(810), 640-655.

Doney, S. C., I. Lima, J. K. Moore, K. Lindsay, M. J. Behrenfeld, T. K. Westberry, N. Mahowald, D. M. Glover, and T. Takahashi (2009b), Skill metrics for confronting global upper ocean ecosystem-biogeochemistry models against field and remote sensing data, Journal of Marine Systems, 76(1-2), 95-112. 
Friedlingstein, P., et al. (2006), Climate-carbon cycle feedback analysis: Results from the $\mathrm{C}^{4} \mathrm{MIP}$ model intercomparison, Journal of Climate, 19(14), 3337-3353.

Friis, K., A. Kortzinger, J. Patsch, and D. W. R. Wallace (2005), On the temporal increase of anthropogenic $\mathrm{CO}_{2}$ in the subpolar North Atlantic, Deep-Sea Research Part IOceanographic Research Papers, 52(5), 681-698.

Fung, I. Y., S. C. Doney, K. Lindsay, and J. John (2005), Evolution of carbon sinks in a changing climate, Proceedings of the National Academy of Sciences of the United States of America, 102(32), 11201-11206.

Gent, P. R., and J. C. McWilliams (1990), Isopycnal Mixing in Ocean Circulation Models, Journal of Physical Oceanography, 20(1), 150-155.

Gonzalez-Davila, M., J. M. Santana-Casiano, and E. F. Gonzalez-Davila (2007), Interannual variability of the upper ocean carbon cycle in the northeast Atlantic Ocean, Geophys. Res. Lett., 34(7).

Gruber, N., J. L. Sarmiento, and T. F. Stocker (1996), An improved method for detecting anthropogenic $\mathrm{CO}_{2}$ in the oceans, Global Biogeochemical Cycles, 10(4), 809-837.

Gruber, N., C. D. Keeling, and N. R. Bates (2002), Interannual variability in the North Atlantic Ocean carbon sink, Science, 298(5602), 2374-2378.

Haine, T. W. N., K. J. Richards, and Y. L. Jia (2003), Chlorofluorocarbon constraints on North Atlantic ventilation, Journal of Physical Oceanography, 33(8), 1798-1814.

Holfort, J., K. M. Johnson, B. Schneider, G. Siedler, and D. W. R. Wallace (1998), Meridional transport of dissolved inorganic carbon in the South Atlantic Ocean, Global Biogeochemical Cycles, 12(3), 479-499.

Hurrell, J., and C. Deser (2009), North Atlantic climate variability: The role of the North Atlantic Oscillation Journal of Marine Systems, 78(1), 28-41.

Hurrell, J., Y. Kushnir, G. Ottersen, and M. Visbeck (Eds.) (2003), An overview of the North Atlantic Oscillation, 1-35 pp., Geophysical Monograph Series.

Hurrell, J. W. (1995), Decadal Trends in the North-Atlantic Oscillation - Regional Temperatures and Precipitation, Science, 269(5224), 676-679. 
Hurrell, J. W., Y. Kushnir, and M. Visbeck (2001), Climate - The North Atlantic oscillation, Science, 291(5504), 603-605.

IPCC (2001), Climate Change 2001: The Scientific Basis. Contribution of Working Group I to the Third Assessment Report of the Intergovernmental Panel on Climate Change 881 pp., Cambridge University Press, Cambridge, United Kingdom and New York, NY, USA.

Jenkins, W. J. (1998), Studying subtropical thermocline ventilation and circulation using tritium and He-3, Journal of Geophysical Research-Oceans, 103(C8), 15817-15831.

Joyce, T. M., C. Deser, and M. A. Spall (2000), The relation between decadal variability of subtropical mode water and the North Atlantic Oscillation, Journal of Climate, 13(14), 2550-2569.

Keeling, C. D., and T. P. Whorf (1994), Atmospheric $\mathrm{CO}_{2}$ records from sites in the SIO air sampling network, in Trends '93: A Compendium of Data on Global Change edited by T. A. Boden, D. P. Kaiser, R. J. Sepanski and F. W. Stoss, pp. 16-26, ORNL/CDIAC-65, Carbon Dioxide Information Analysis Center, Oak Ridge National Laboratory, Oak Ridge, Tennessee.

Keeling, C. D., R. B. Bacastow, A. E. Bainbridge, C. A. Ekdahl, P. R. Guenther, L. S. Waterman, and J. F. S. Chin (1976), Atmospheric Carbon-Dioxide Variations at MaunaLoa Observatory, Hawaii, Tellus, 28(6), 538-551.

Large, W. G., and S. G. Yeager (2004), Diurnal to decadal global forcing for ocean and sea-ice models: The data sets and flux climatologies, NCAR Technical Note NCAR/TN$460+$ STR.

Lefevre, N., A. J. Watson, A. Olsen, A. F. Rios, F. F. Perez, and T. Johannessen (2004), A decrease in the sink for atmospheric CO2 in the North Atlantic, Geophys. Res. Lett., 31(7).

Levine, N. M., S. C. Doney, R. Wanninkhof, K. Lindsay, and I. Y. Fung (2008), Impact of ocean carbon system variability on the detection of temporal increases in anthropogenic CO2, Journal of Geophysical Research-Oceans, 113(C3).

Lohmann, K., H. Drange, and M. Bentsen (2009), Response of the North Atlantic subpolar gyre to persistent North Atlantic oscillation like forcing, Climate Dynamics, 32(2-3), 273-285. 
Lovenduski, N. S., N. Gruber, and S. C. Doney (2008), Toward a mechanistic understanding of the decadal trends in the Southern Ocean carbon sink, Global Biogeochemical Cycles, 22(3).

Macdonald, A. M., M. O. Baringer, R. Wanninkhof, K. Lee, and D. W. R. Wallace (2003), A 1998-1992 comparison of inorganic carbon and its transport across 24.5 degrees N in the Atlantic, Deep-Sea Research Part Ii-Topical Studies in Oceanography, 50(22-26), 3041-3064.

Marshall, J., Y. Kushner, D. Battisti, P. Chang, A. Czaja, R. Dickson, J. Hurrell, M. McCartney, R. Saravanan, and M. Visbeck (2001), North Atlantic climate variability: Phenomena, impacts and mechanisms, International Journal of Climatology, 21(15), 1863-1898.

Marshall, J., et al. (2009), The CLIMODE field campaign: observing the cycle of convection and restratification over the Gulf Stream, Bulletin of the American Meteorological Society, 90(9).

Marshall, J. C., A. J. G. Nurser, and R. G. Williams (1993), Inferring the subduction rate and period over the North Atlantic, Journal of Physical Oceanography, 23(7), 13151329.

Matsumoto, K., and N. Gruber (2005), How accurate is the estimation of anthropogenic carbon in the ocean? An evaluation of the $\Delta \mathrm{C}^{*}$ method, Global Biogeochemical Cycles, 19(3).

McCartney, M. S., and L. D. Talley (1982), The sub-polar mode water of the North Atlantic ocean, Journal of Physical Oceanography, 12(11), 1169-1188.

Meehl, G. A., et al. (2007), Global Climate Projections. In: Climate Change 2007: The Physical Scince Basis. Contribution of Working Group I to the Fourth Assesment Report of the Intergovernmental Panel on Climate Change., in Climate Change 2007: The Physical Scince Basis. Contribution of Working Group I to the Fourth Assesment Report of the Intergovernmental Panel on Climate Change, edited by S. Solomon, D. Qin, M. Manning, Z. Chen, M. Marquiz, K. B. Averyt, M. Tignor and H. L. Miller, Cambridge University Press, Cambridge, United Kingdom and New York, NY, USA.

Mikaloff Fletcher, S. E., et al. (2006), Inverse estimates of anthropogenic CO2 uptake, transport, and storage by the ocean, Global Biogeochemical Cycles, 20(2). 
Moore, J. K., S. C. Doney, and K. Lindsay (2004), Upper ocean ecosystem dynamics and iron cycling in a global three-dimensional model, Global Biogeochemical Cycles, 18(4).

Olsen, A., et al. (2006), Magnitude and origin of the anthropogenic CO2 increase and C13 Suess effect in the Nordic seas since 1981, Global Biogeochemical Cycles, 20(3).

Omar, A. M., and A. Olsen (2006), Reconstructing the time history of the air-sea CO2 disequilibrium and its rate of change in the eastern subpolar North Atlantic, 1972-1989, Geophys. Res. Lett., 33(4).

Perez, F. F., M. Vazquez-Rodriguez, E. Louarn, X. A. Padin, H. Mercier, and A. F. Rios (2008), Temporal variability of the anthropogenic CO2 storage in the Irminger Sea, Biogeosciences, 5(6), 1669-1679.

Robbins, P. E., and W. J. Jenkins (1998), Observations of temporal changes of tritiumHe-3 age in the eastern North Atlantic thermocline: Evidence for changes in ventilation?, Journal of Marine Research, 56(5), 1125-1161.

Rodgers, K. B., et al. (in press), Altimetry helps to explain patchy changes in hydrographic carbon measurements, Journal of Geophysical Research-Oceans.

Sabine, C. L., et al. (2004), The oceanic sink for anthropogenic $\mathrm{CO}_{2}$, Science, 305(5682), 367-371.

Sarmiento, J. L., R. Murnane, and C. Lequere (1995), Air-Sea Co2 Transfer and the Carbon Budget of the North-Atlantic, Philosophical Transactions of the Royal Society of London Series B-Biological Sciences, 348(1324), 211-219.

Schuster, U., and A. J. Watson (2007), A variable and decreasing sink for atmospheric $\mathrm{CO} 2$ in the North Atlantic, Journal of Geophysical Research-Oceans, 112(C11).

Schuster, U., A. J. Watson, N. R. Bates, A. Corbiere, M. Gonzalez-Davila, N. Metzl, D. Pierrot, and M. Santana-Casiano (2009), Trends in North Atlantic sea-surface fCO(2) from 1990 to 2006, Deep-Sea Research Part Ii-Topical Studies in Oceanography, 56(8$10), 620-629$.

Talley, L., and M. Raymer (1982), Eighteen Degree Water variability, Journal of Marine Research, 40 (Suppl.), 757-775. 
Talley, L. D., and M. S. McCartney (1982), Distribution and circulation of Labrador Sea Water, Journal of Physical Oceanography, 12(11), 1189-1205.

Taylor, A. H., and J. A. Stepens (1998), The North Atlantic oscillation and the latitude of the Gulf Stream, Tellus Series a-Dynamic Meteorology and Oceanography, 50(1), 134142.

Thomas, H., A. E. F. Prowe, I. D. Lima, S. C. Doney, R. Wanninkhof, R. J. Greatbatch, U. Schuster, and A. Corbiere (2008), Changes in the North Atlantic Oscillation influence $\mathrm{CO} 2$ uptake in the North Atlantic over the past 2 decades, Global Biogeochemical Cycles, 22(4).

Thorpe, R. B., J. M. Gregory, T. C. Johns, R. A. Wood, and J. F. B. Mitchell (2001), Mechanisms determining the Atlantic thermohaline circulation response to greenhouse gas forcing in a non-flux-adjusted coupled climate model, Journal of Climate, 14(14), 3102-3116.

Vazquez-Rodriguez, M., F. Touratier, C. Lo Monaco, D. W. Waugh, X. A. Padin, R. G. J. Bellerby, C. Goyet, N. Metzl, A. F. Rios, and F. F. Perez (2009), Anthropogenic carbon distributions in the Atlantic Ocean: data-based estimates from the Arctic to the Antarctic, Biogeosciences, 6(3), 439-451.

Visbeck, M., E. P. Chassignet, R. Curry, T. L. Delworth, R. R. Dickson, and G. Krahmann (Eds.) (2003), The ocean's response to North Atlantic Oscillation variability, 113-146 pp., Geophysical Monograph Series.

Wallace, D. (2001), Storage and transport of excess $\mathrm{CO}_{2}$ in the ocean: The JGOFS/WOCE global $\mathrm{CO}_{2}$ survey, in Ocean Circulation and Climate, edited by $\mathrm{G}$. Siedler, J. Church and J. Gould, pp. 489-521, Academic Press, San Diego, CA.

Wanninkhof, R., S. Doney, J. L. Bullister, N. M. Levine, M. Warner, and N. Gruber (in prep), Decadal Changes in Inorganic Carbon along Meridional Section A16 in the Atlantic Ocean from 1989-2005: Separating Natural Variability from Anthropogenic Input.

Waugh, D. W., T. W. N. Haine, and T. M. Hall (2004), Transport times and anthropogenic carbon in the subpolar North Atlantic Ocean, Deep-Sea Research Part IOceanographic Research Papers, 51(11), 1475-1491. 
TABLE 3.1: The relationship between the wintertime NAO index and changes in the Eighteen Degree Water (EDW) and Subpolar Mode Water (SPMW) outcrops and isopycnal surfaces.

\begin{tabular}{|l|r|r|r|r|}
\hline Relationship to NAO & \multicolumn{1}{l|}{ slope } & \multicolumn{1}{l|}{ error } & R value & p value \\
\hline Subtropical EDW & 0.0039 & 0.002 & 0.34 & 0.057 \\
\hline dI/dt $(\Delta$ Physics), 2yr lag $*$ & 2.7 & 1.7 & 0.27 & 0.129 \\
\hline Outcrop mean MLD ( $\Delta$ Physics) & 0.0002 & 0.0001 & 0.28 & 0.115 \\
\hline Outcrop CO2 flux $(\Delta$ Physics) & 0.0031 & 0.001 & 0.48 & 0.0054 \\
\hline Subpolar Mode Water & 7.57 & 1.65 & 0.63 & $5.0 \mathrm{E}-05$ \\
\hline dI/dt ( $\Delta$ Physics), Oyr lag $* *$ & 0.0004 & 0.00008 & 0.62 & $7.1 \mathrm{E}-05$ \\
\hline mean subpolar MLD ( $\Delta$ Physics)
\end{tabular}

$*$ for $\sigma 26.5$ between $15-40 \mathrm{~N}$ and $70-25 \mathrm{~W}$ for the upper $150 \mathrm{~m}$

$* *$ for $027.675-27.7$ between $45-66 \mathrm{~N}$ and $57-18 \mathrm{~W}$

$* * *$ for $027.6-27.7$ 


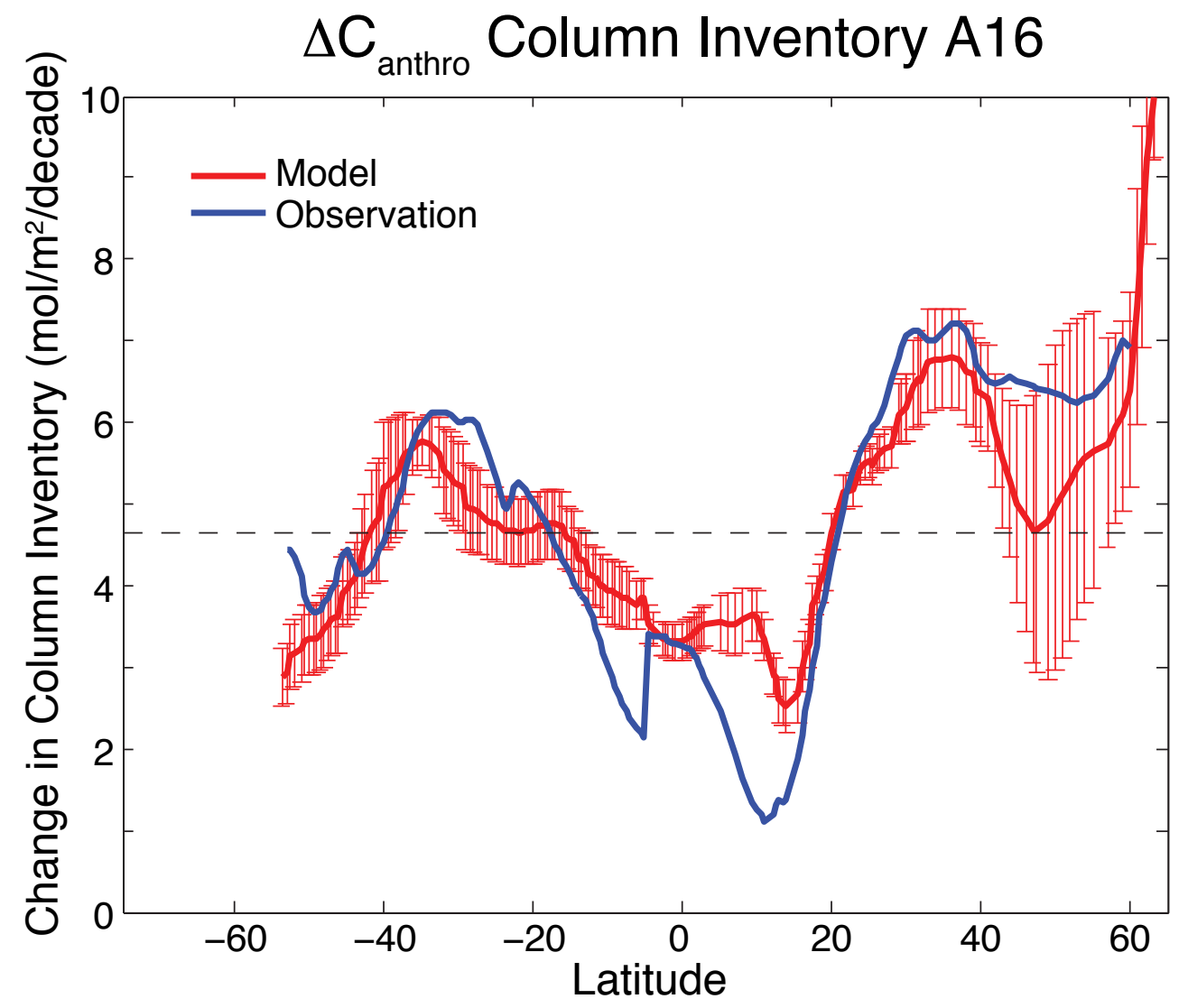

Figure 3.1: Comparison between model and observational estimates of the rate of change of $C_{\text {anthro }}$ column inventory along the Atlantic north-south A16 transect. Model error bars represent the natural variability in the model system and are calculated as the RMS error of the decadal change in the $C_{\text {anthro }}$ column inventory calculated for each month between January 1989 and December 2004. 
a)

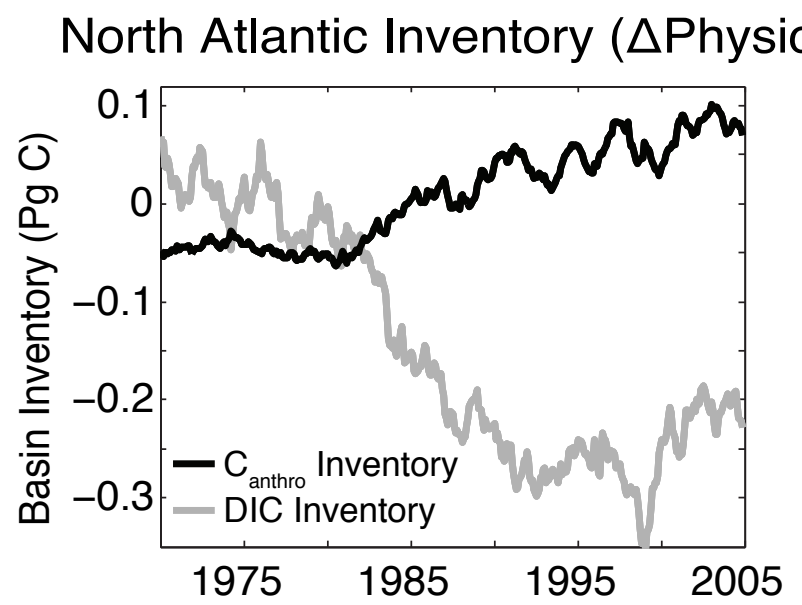

b)

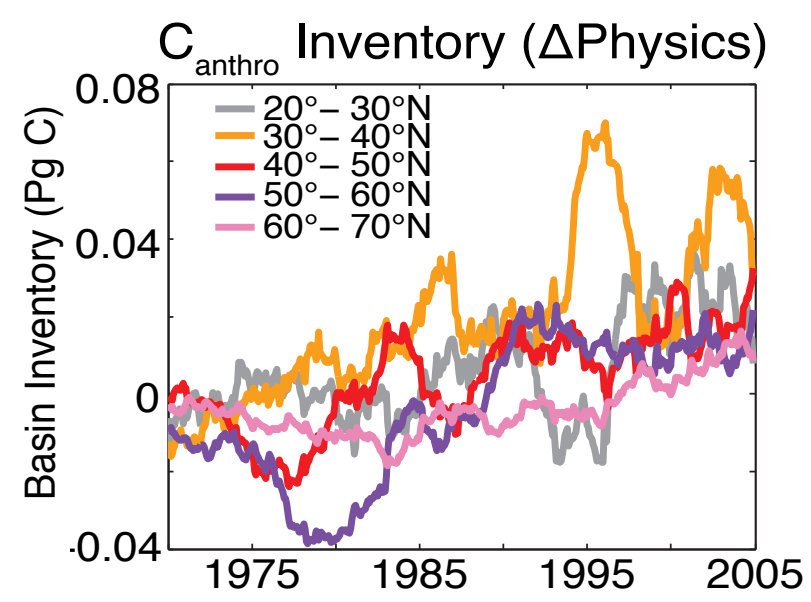

c)

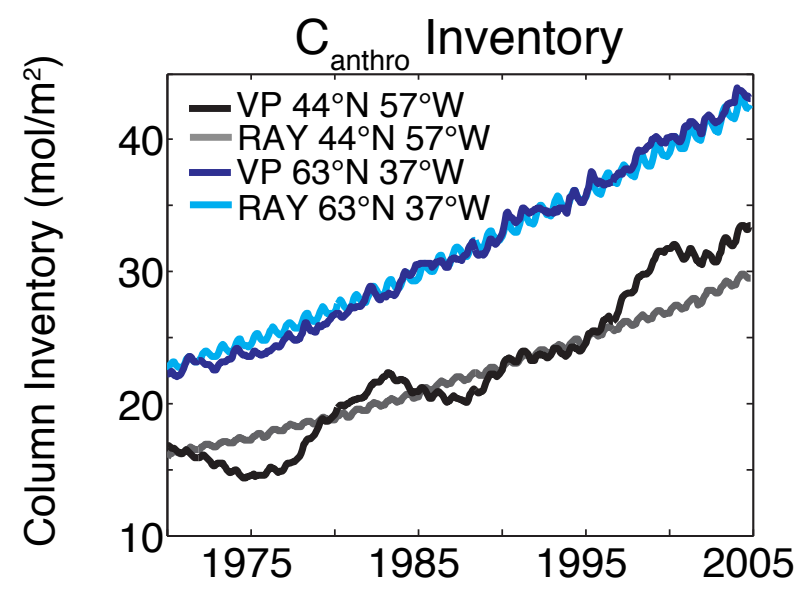

Figure 3.2: Change in model $C_{\text {anthro }}$ inventory with time for a) the North Atlantic basin, $15^{\circ}-70^{\circ} \mathrm{N}, \mathrm{b}$ ) latitude band inventories, and c) column inventories for $44^{\circ} \mathrm{N} 57^{\circ} \mathrm{W}$ and $63^{\circ} \mathrm{N} 37^{\circ} \mathrm{W}$. All inventories are calculated for the upper $1280 \mathrm{~m}$. Panels a) and b) plot the $\Delta$ physics inventories where $\Delta$ physics is a measure of ocean sensitivity to variable climate and ocean circulation as defined by equation (2). Panel a) plots the impact of variable physics ( $\Delta$ physics) on both the $C_{\text {anthro }}$ inventory (black line) and the total carbon inventory (gray line). Panel c) plots the output for both the VP and RAY model simulations. 
a)

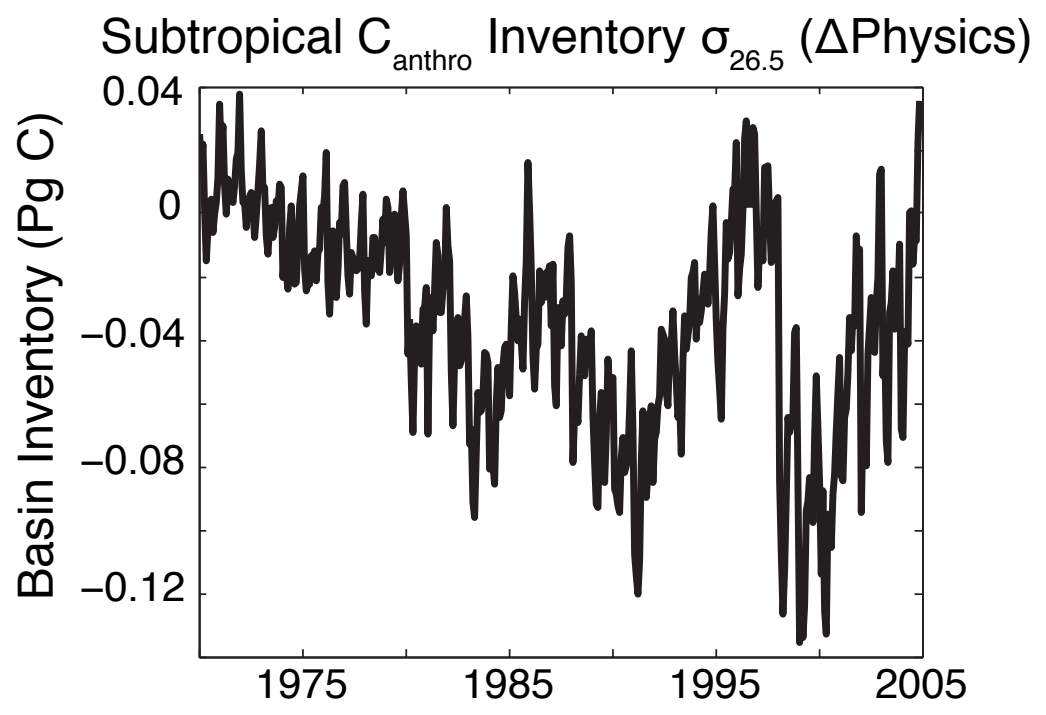

b)

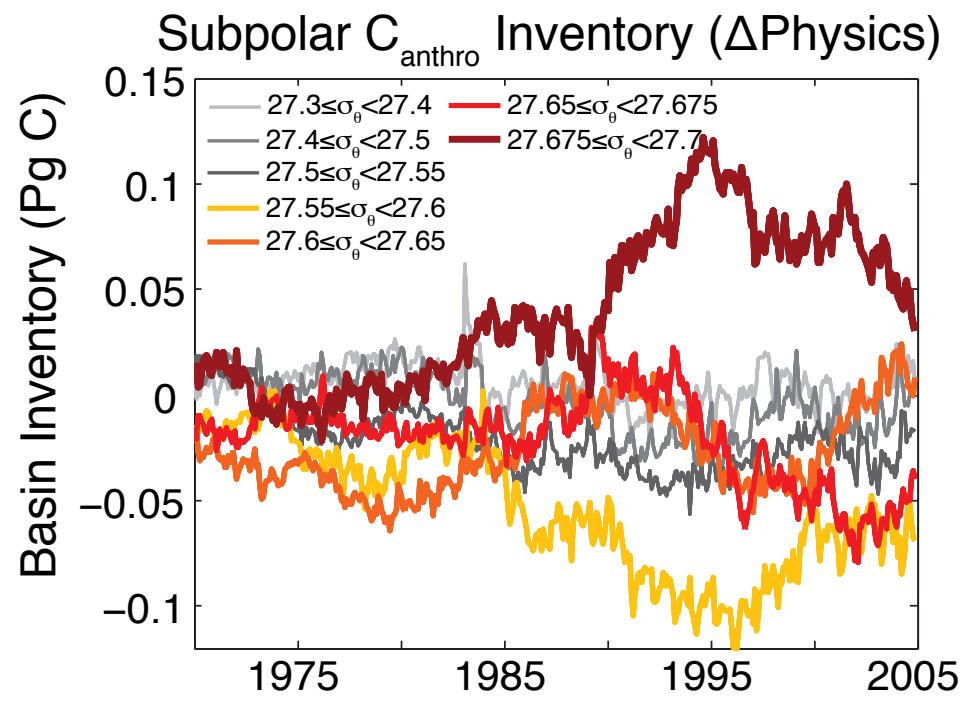

Figure 3.3: Sensitivity of model isopycnal band anthropogenic carbon inventories to variable physics for a) the subtropical $\sigma_{26.5}$ isopycnal surface between $15^{\circ}-40^{\circ} \mathrm{N}, 20^{\circ}-70^{\circ} \mathrm{W}$ and $>150 \mathrm{~m}$ and $\mathrm{b}$ ) subpolar SPMW isopycnal surfaces $\left(\sigma_{27.3-27.7}\right)$ between $45^{\circ}-66^{\circ} \mathrm{N}, 57^{\circ}-18^{\circ} \mathrm{W}$. Both panels present $\Delta$ physics inventories where $\Delta$ physics is defined by equation (2). 
a)

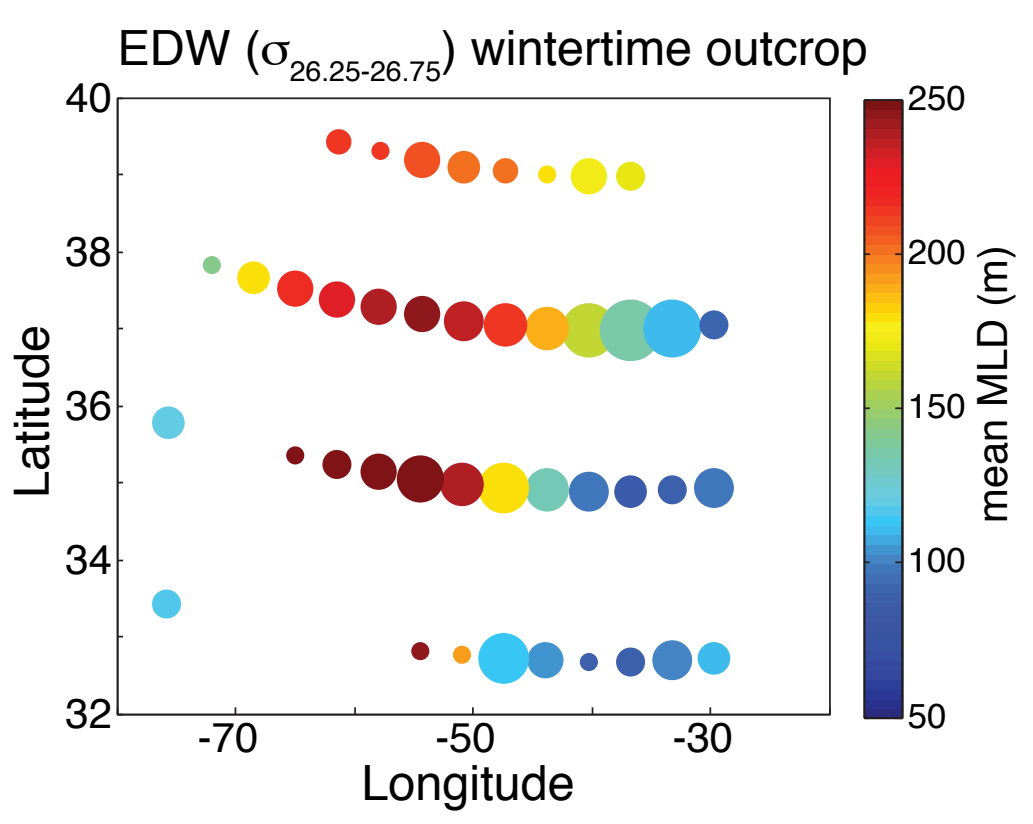

b)

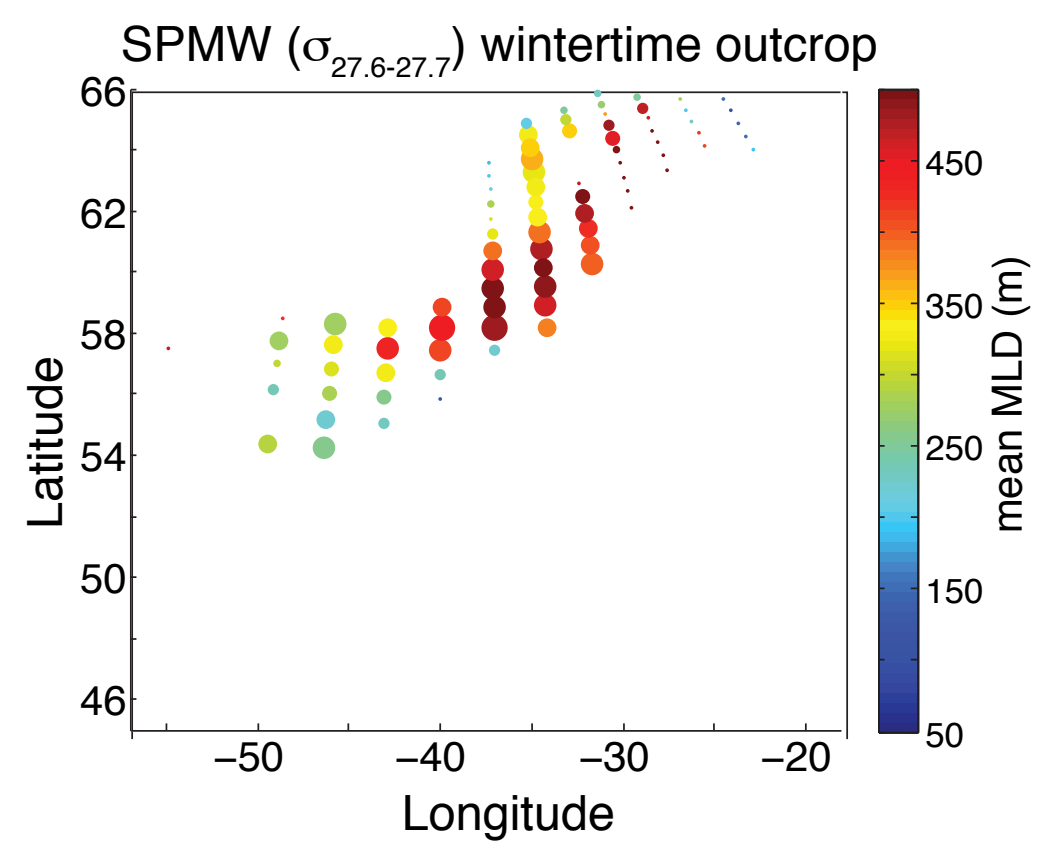

Figure 3.4: Wintertime (January- March) outcrop for a) Eighteen Degree Water $(\mathrm{EDW}), \sigma_{26.25-26.75}$, and b) Subpolar Mode Water (SPMW), $\sigma_{27.6-27.7}$, for the Variable Physics model simulation. The colorbars indicate the mean wintertime mixed layer depth (MLD) in meters for 1970-2004. The circle size is proportional to the RMS of mean wintertime MLD for points with an RMS greater than $5 \mathrm{~m}$. 
a)

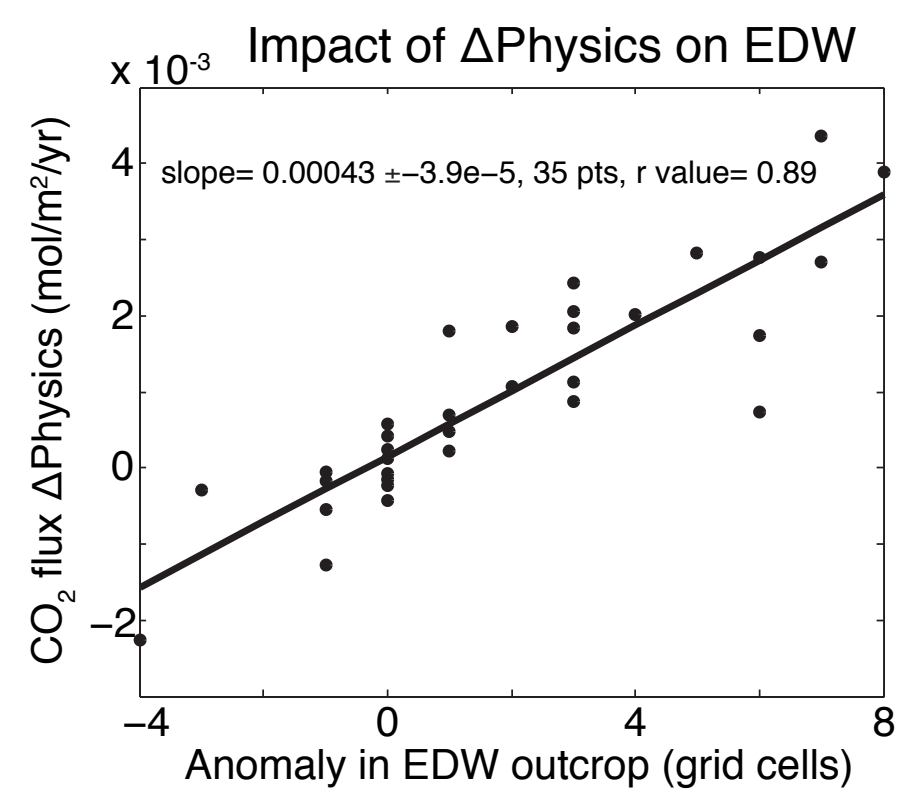

b)

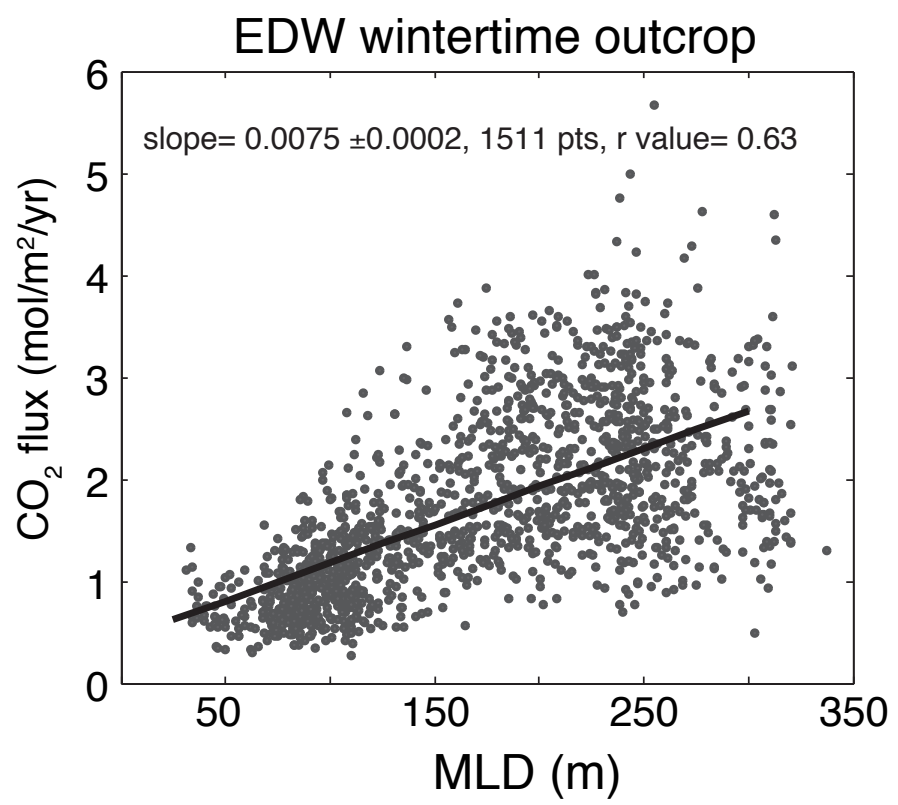

Figure 3.5: Impact of variable physics on the Eighteen Degree Water (EDW) formation region and $C_{\text {anthro }} \mathrm{CO}_{2}$ uptake. Panel a) shows the strong positive relationship between $\mathrm{CO}_{2}$ air-sea flux and size of the EDW outcrop region as represented by the anomaly in number of model grid cells. Panel b) displays the relationship between anthropogenic $\mathrm{CO}_{2}$ air-sea flux and MLD for the EDW formation region. Panel a) plots $\Delta$ physics values whereas panel b) plots absolute values for the VP simulation. 
a)

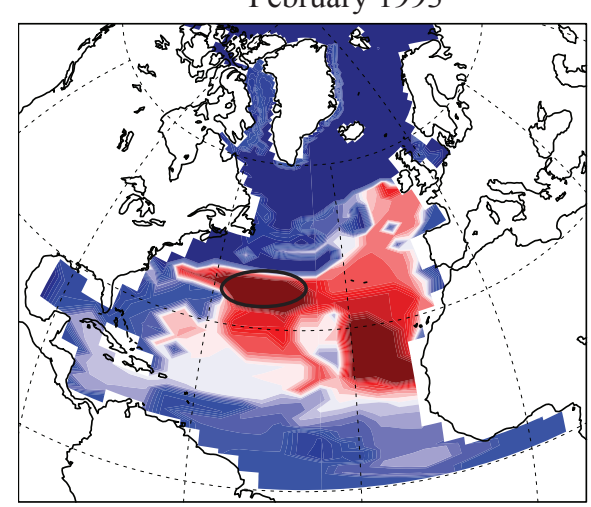

June 1993

c)

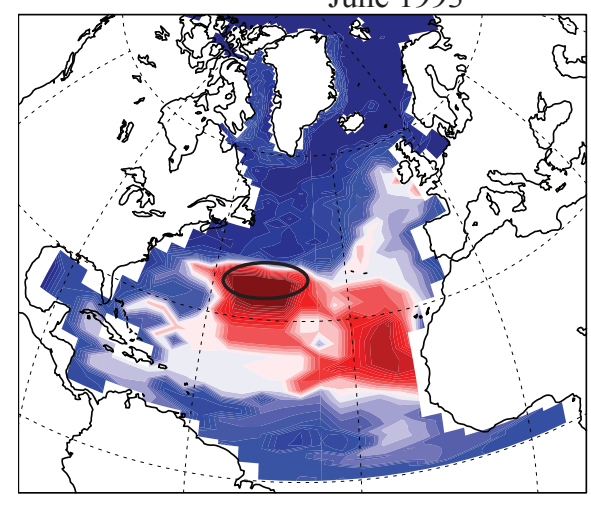

b)

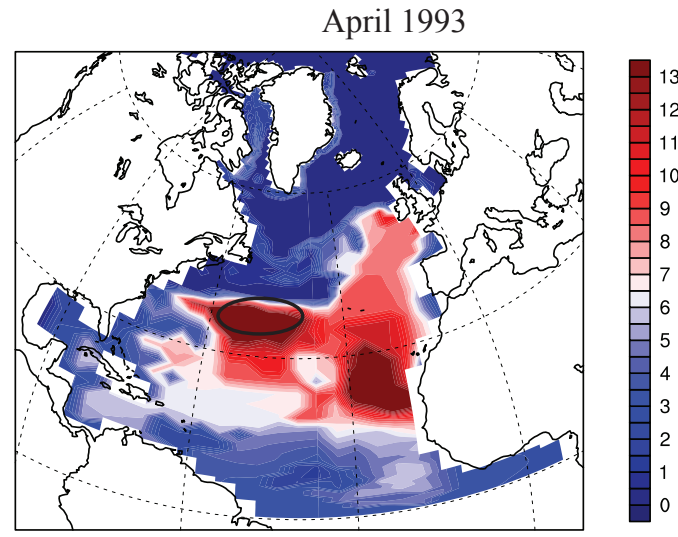

d)

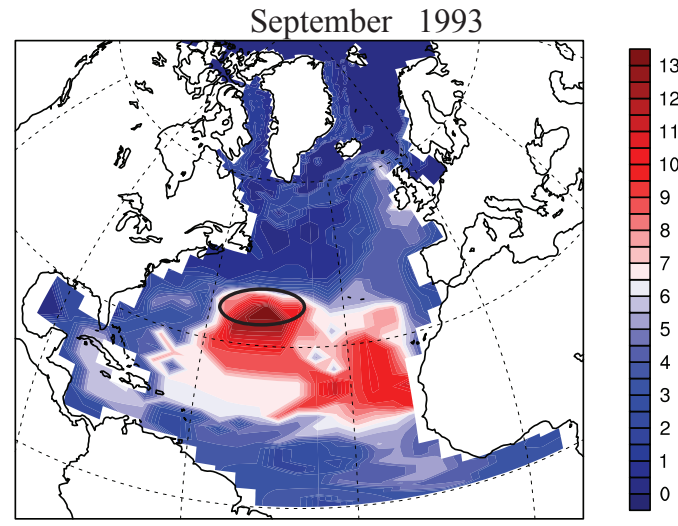

Figure 3.6: Impact of transport on the variability of $\mathrm{C}_{\text {anthro }}$ isopycnal inventory $\left(\mathrm{mol} / \mathrm{m}^{2}\right)$ along the $\sigma_{26.5}$ isopycnal surface. Panels a)-d) show the $\mathrm{C}_{\text {anthro }} \sigma_{26.5}$ isopycnal inventory for February 1993, April 1999, June 1993, and September 1999, respectively. The black circle denotes the EDW formation region from Figure 4a. 


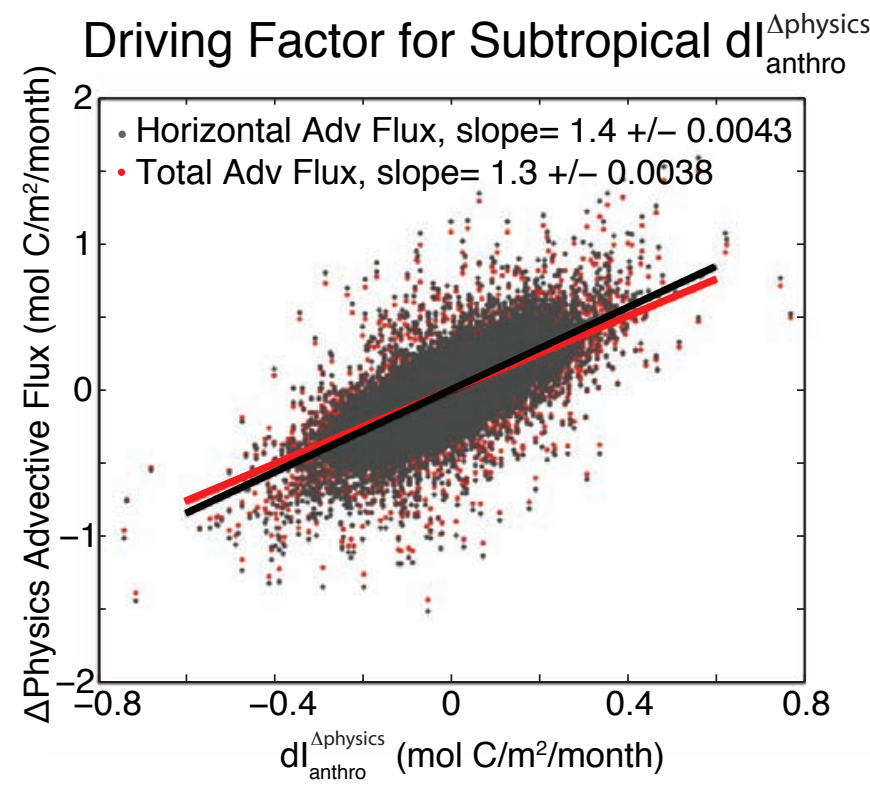

Figure 3.7: Driving factors for changes in the subtropical gyre $I_{\text {anthro }}$. Monthly changes in $I_{\text {anthro }}^{\Delta \text { shsics }}$ are plotted against the horizontal (gray) and total (red) advective convergences ( $\Delta$ physics). The horizontal transport of $C_{\text {anthro }}$ is the dominant factor contributing to $d I_{\text {anthro }}^{\text {Lphyics }}$ 
a)

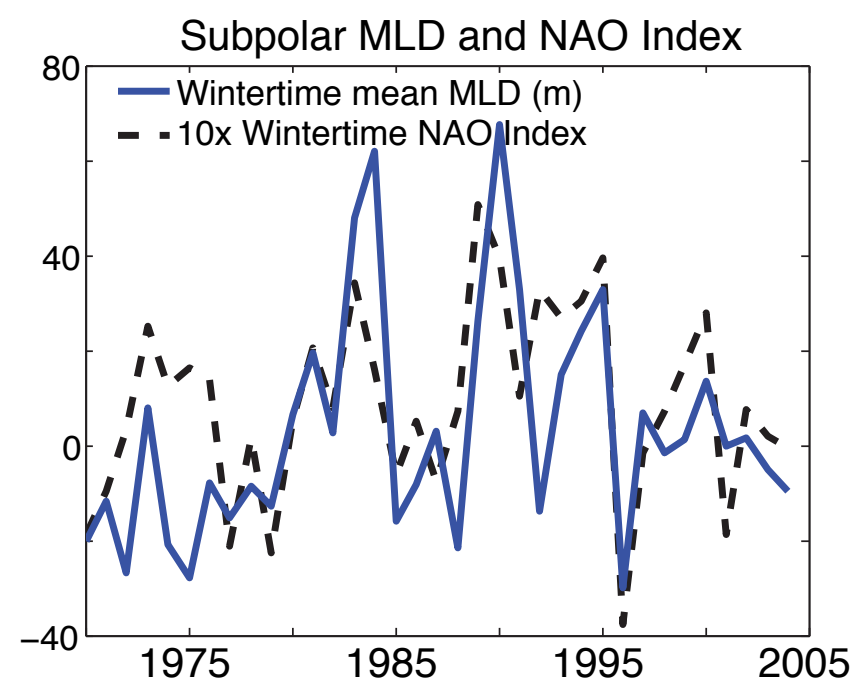

b)

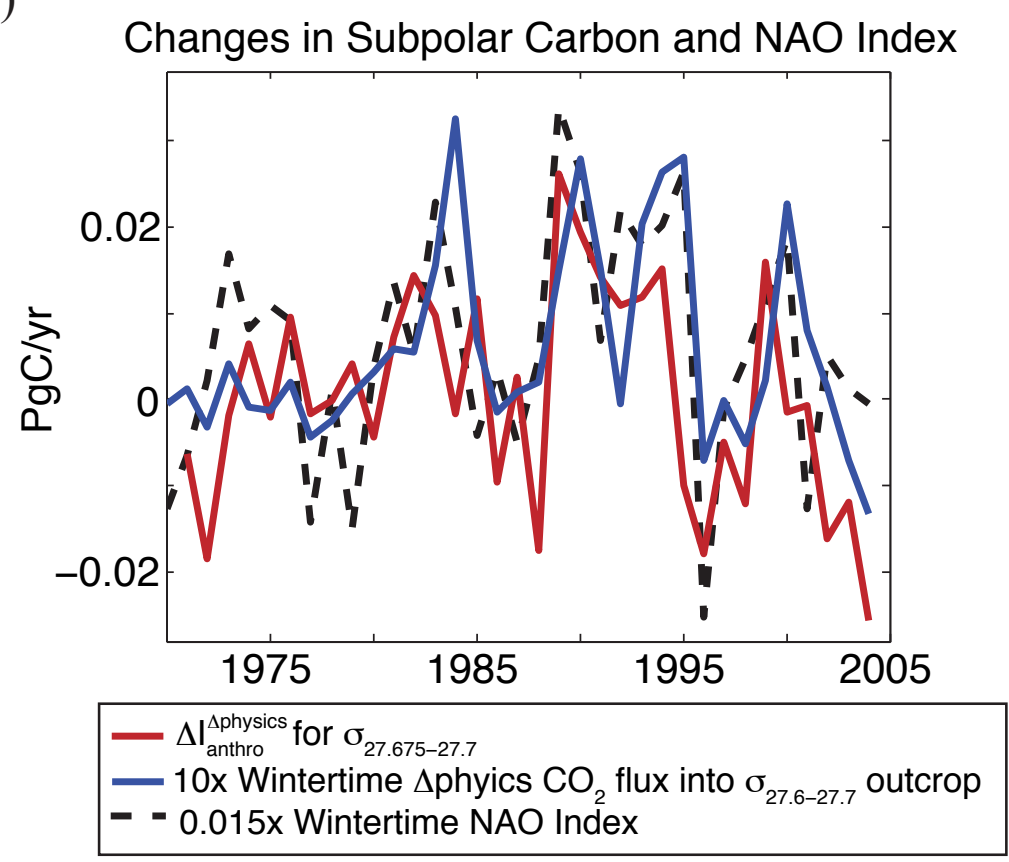

Figure 3.8: Impact of the NAO on model subpolar mixed layer depths and anthropogenic carbon fluxes. Panel a) shows the strong positive relationship between mean wintertime mixed layer depth (MLD) for the subpolar gyre, $46^{\circ}-66^{\circ} \mathrm{N} 57^{\circ}-18^{\circ} \mathrm{W}$, and the wintertime NAO index (scaled by a factor of 10). Panel b) shows the positive relationship between NAO index (scaled by a factor of 0.015 ), the impact of variable ocean physics on the change in anthropogenic carbon inventory $\left(\Delta I_{\text {anthro }}^{\text {phhsics }}\right.$ in $\left.\mathrm{PgC} / \mathrm{yr}\right)$ for $\sigma_{27.675-27.7}$, and the impact of variable ocean physics on the anthropogenic $\mathrm{CO}_{2}$ air-sea flux into the $\sigma_{27.6-27.7}$ wintertime outcrop (scaled by a factor of 10). The impact of variable ocean physics ( $\Delta$ physics) is defined by equation (2). 


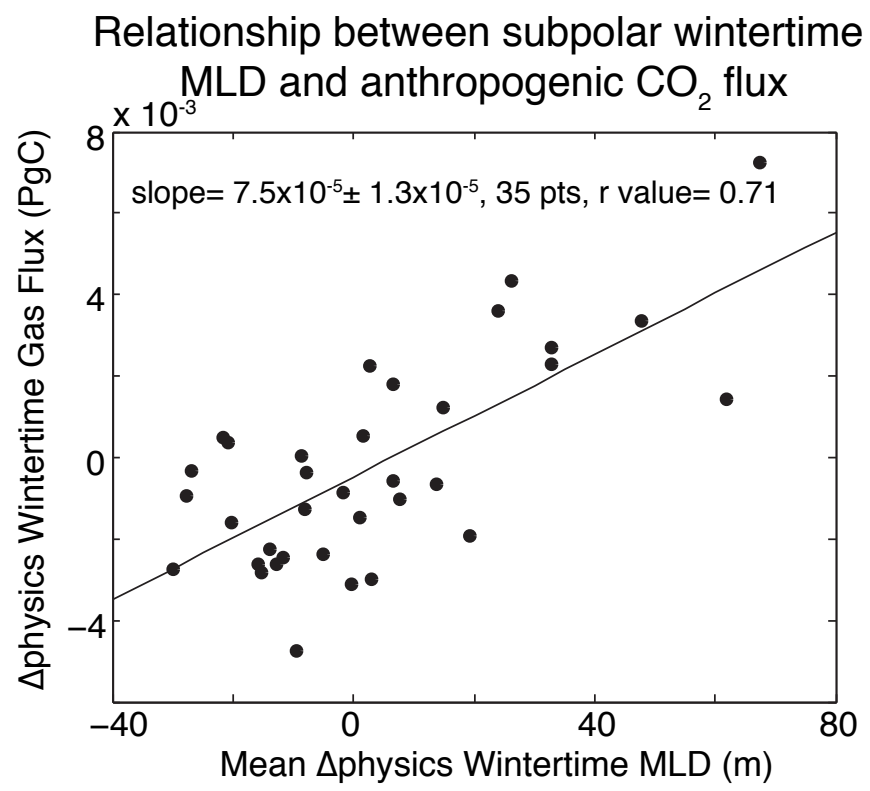

Figure 3.9: The model relationship between anthropogenic air-sea $\mathrm{CO}_{2}$ flux and mean mixed layer depth (MLD) for the subpolar gyre, $46^{\circ}-66^{\circ} \mathrm{N} 57^{\circ}-18^{\circ} \mathrm{W}$. $\Delta$ physics values are used where $\Delta$ physics is defined by equation (2). 
a)

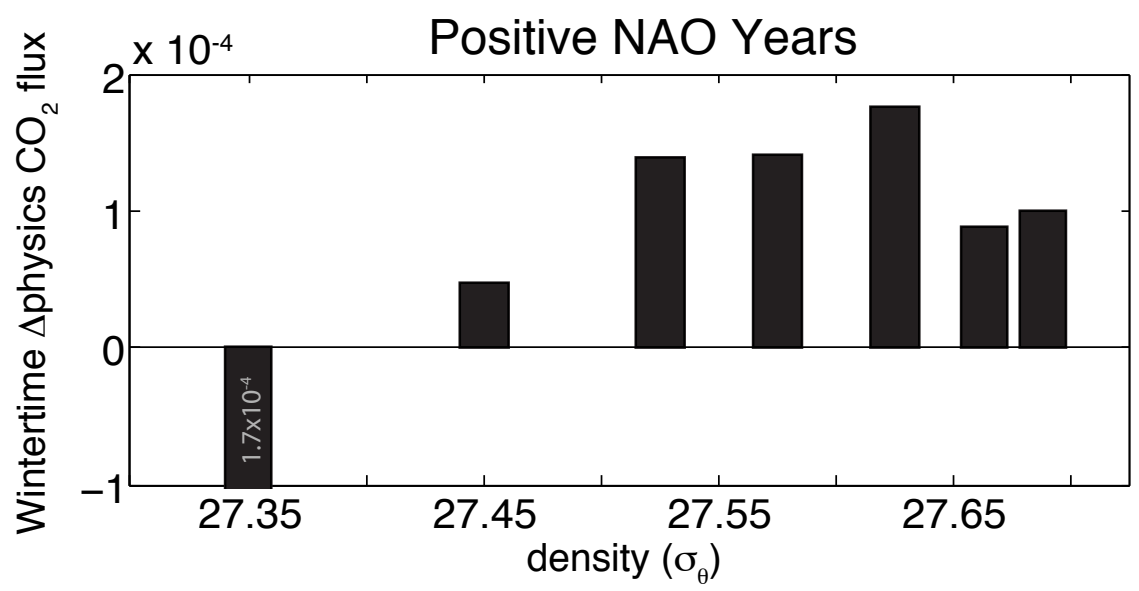

b)

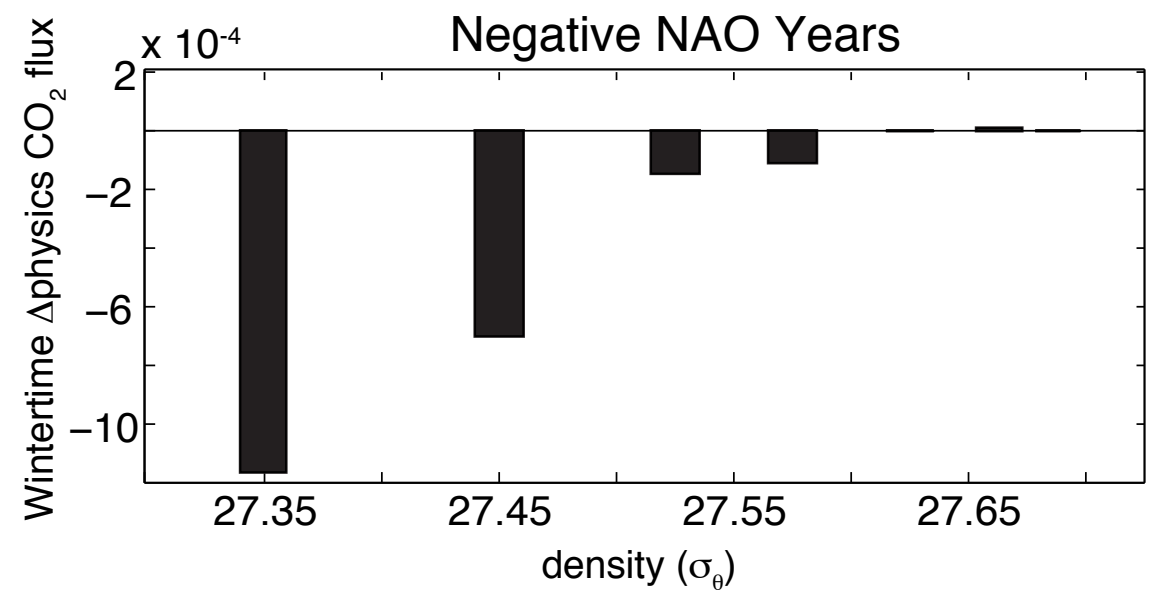

Figure 3.10: Wintertime air-sea $\mathrm{CO}_{2}$ flux onto subpolar mode water isopycnal surfaces $\left(\sigma_{27.3-27.7}\right)$. The impact of variable ocean physics on the wintertime $\mathrm{CO}_{2}$ flux onto seven isopycnal surfaces are shown for positive, panel a), and negative NAO years, panel $b$ ). The flux onto the isopycnal surfaces is defined as the total flux into model cells for which the wintertime mixed layer intersects with the wintertime depth of isopycnal band. Note the difference in scales for panels a) and b). 
a)

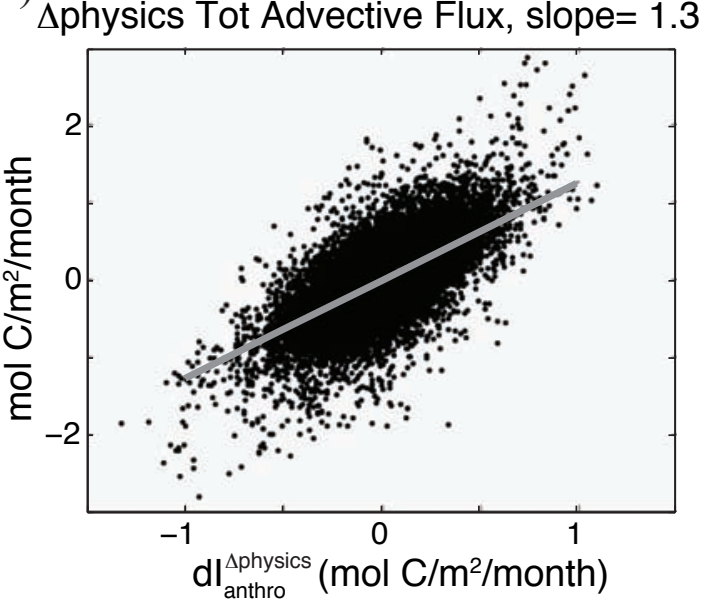

c) ${ }_{\Delta \text { physics Vert Advective Flux, slope }=-0.56}$

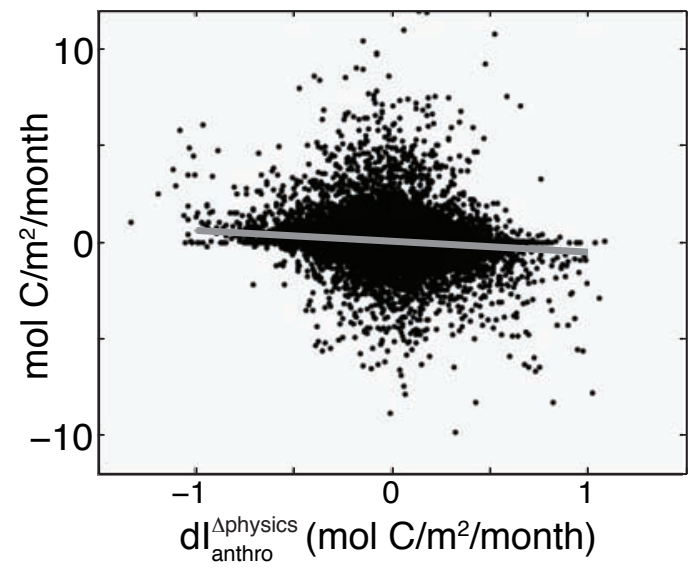

b)

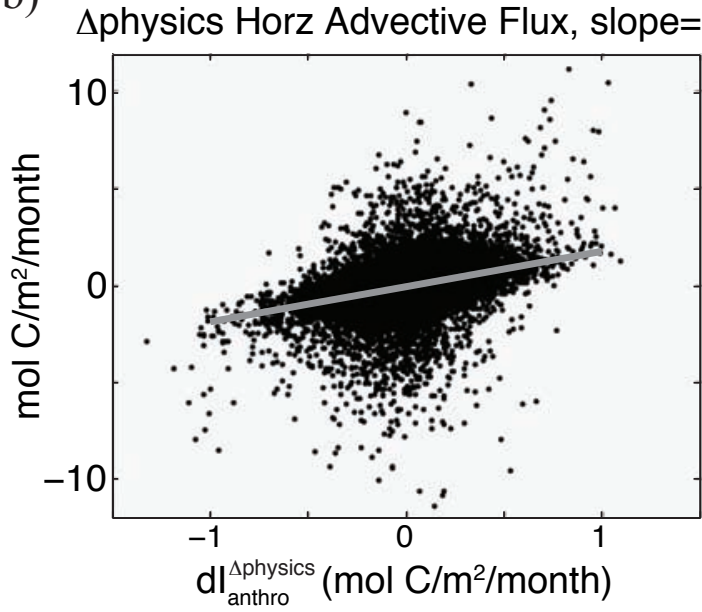

d)
$\Delta$ physics Horz Advective Flux, slope $=1.8$

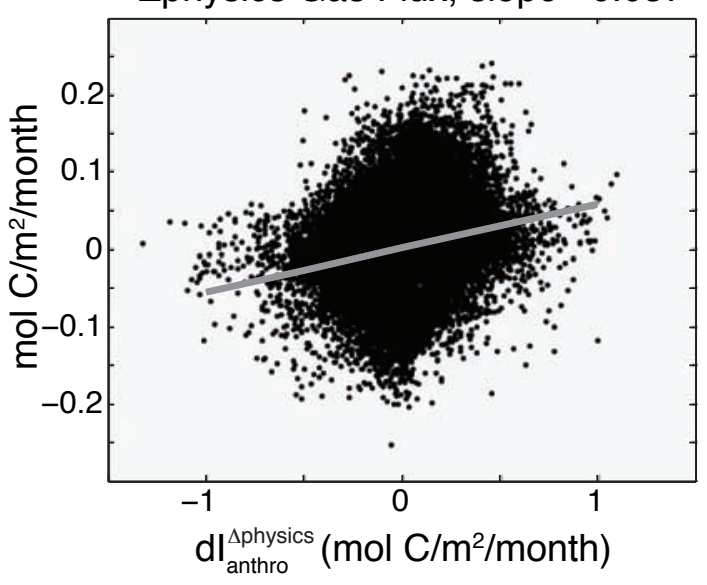

Figure 3.11: Driving factors for changes in model subpolar $I_{\text {anthro" }}^{\Delta \text { phyics }}$ Monthly $\mathrm{dI}_{\text {anthro }}^{\Delta \text { physics }}$ for subpolar model grid cells are plotted against the total (a), horizontal (b) and vertical (c) advective convergence and the $\mathrm{CO}_{2}$ air-sea flux (d) ( $\Delta$ physics). Linear fits to the data are shown in gray and the slopes for the linear fits are given in the panel titles. $\Delta$ physics convergences and fluxes are used where $\Delta$ physics is defined by equation (2). The advective transport of $\mathrm{C}_{\text {anthro }}$ is the dominant factor contributing to monthly changes in subpolar $\mathrm{I}_{\text {anthro" }}^{\text {Lphyics }}$ 

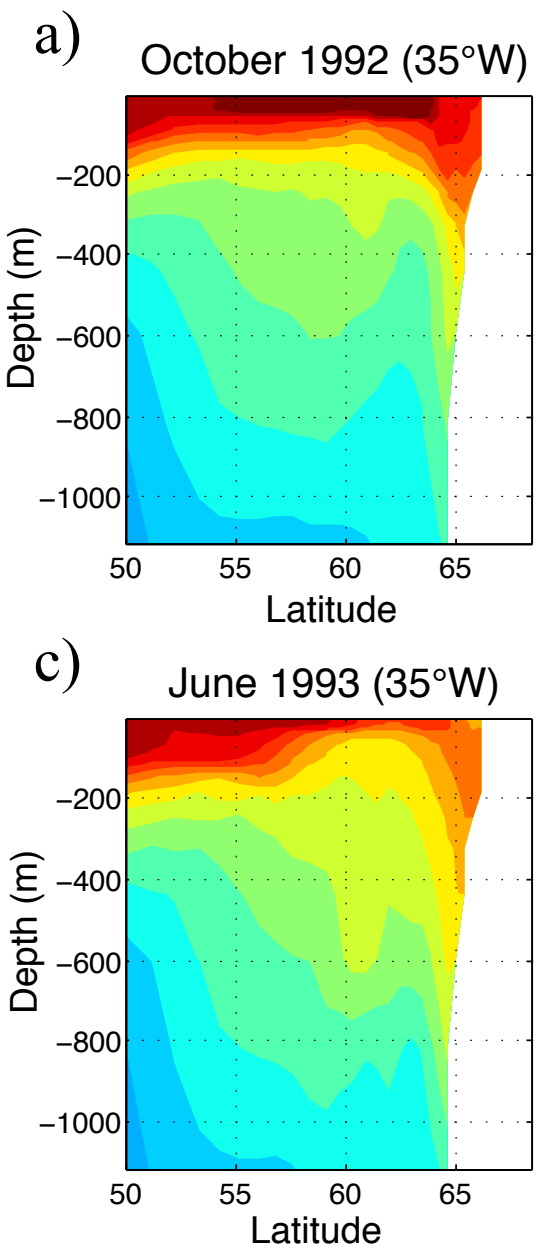
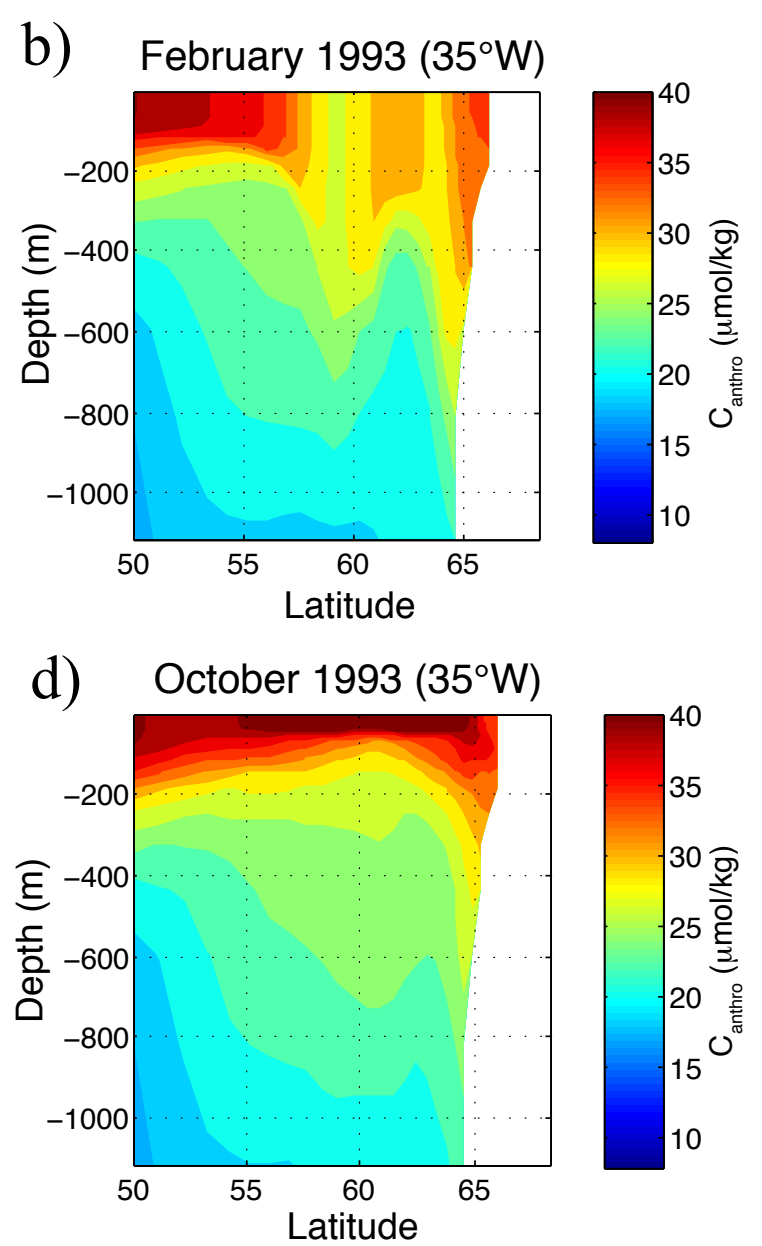

Figure 3.12: Water mass transformation in the model subpolar gyre. Panels a)-d) plot $\mathrm{VPC}_{\text {anthro }}\left(\mu \mathrm{mol} / \mathrm{kg}\right.$ ) along a north-south transect at $35^{\circ} \mathrm{W}$ for October 1992, and February, June, and October 1993, respectively. In October, panels a) and d), high $\mathrm{C}_{\text {anthro }}$ concentrations are observed in the stratified surface waters. During the deep winter mixing events, panel $b$ ), these high $\mathrm{C}_{\text {anthro }}$ waters are mixed with underlying low $\mathrm{C}_{\text {anthro }}$ waters resulting in dense, high $\mathrm{C}_{\text {anthro }}$ mode waters. In the spring and summer, stratification of the surface waters return but the remnants of high $\mathrm{C}_{\text {anthro }}$ from the winter mixing is still apparent at depth, panel c). 
a) Mean Subtropical [Carbon] ( $\Delta$ physics)

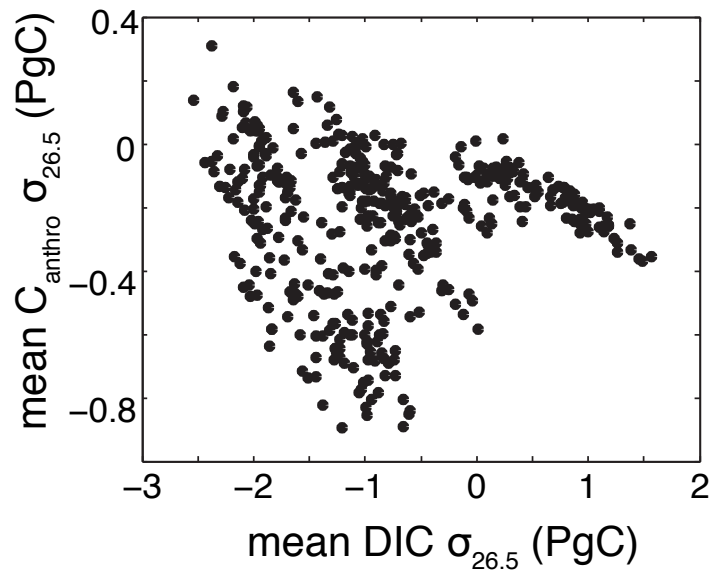

b) Mean Subpolar [Carbon] ( $\triangle$ physics)

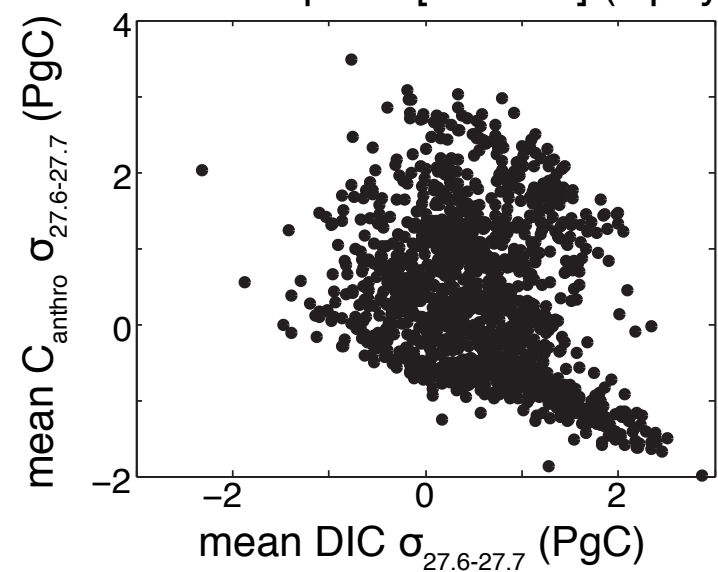

Figure 3.13: Relationship between total and anthropogenic carbon. Panels a) and b) display the relationship between mean isopycnal total carbon concentration (DIC) and mean anthropogenic carbon concentration $\left(C_{\text {anthro }}\right)$ for the subtropics $\left(\sigma_{26.5}\right)$ and subpolar $\left(\sigma_{27.6-27.7}\right)$ gyres, respectively. $\Delta$ physics concentrations are used where $\Delta$ physics is defined by equation (2). 
a)

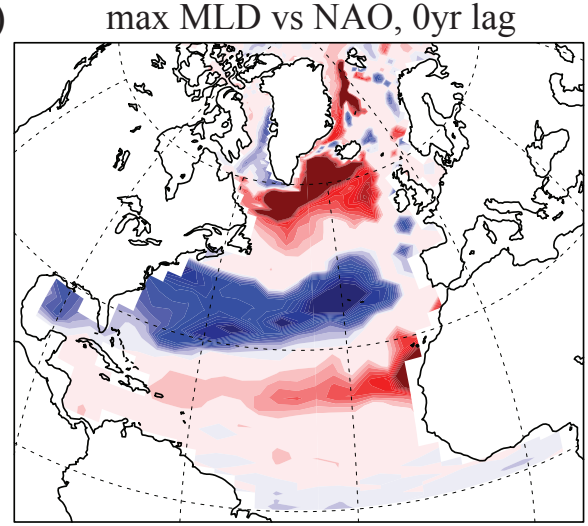

c)

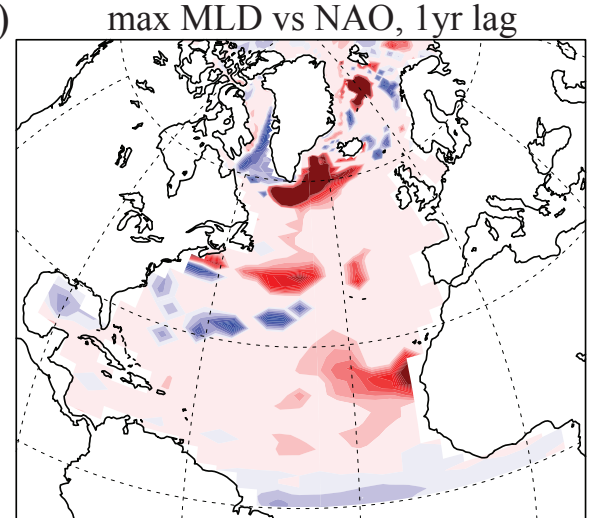

e)

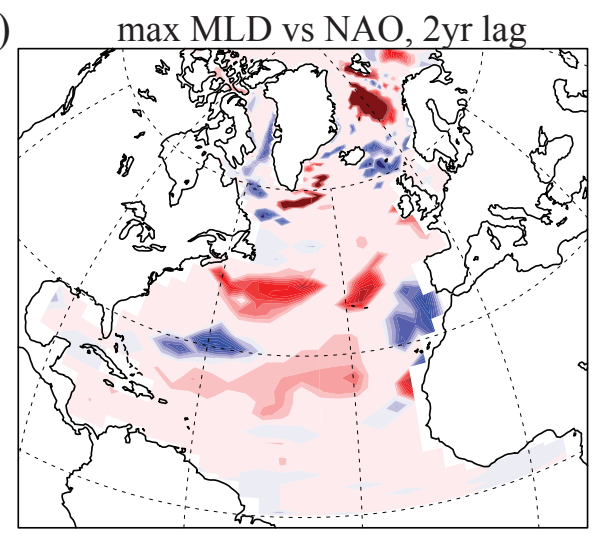

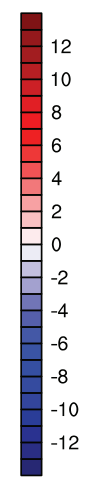

b)

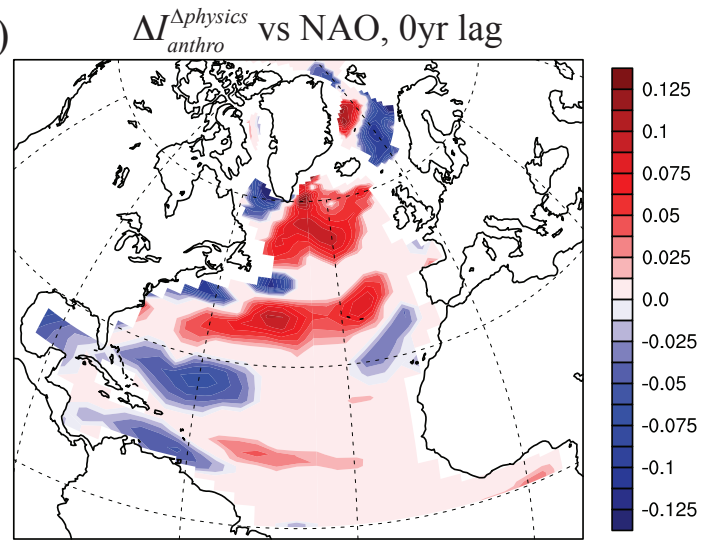

d)

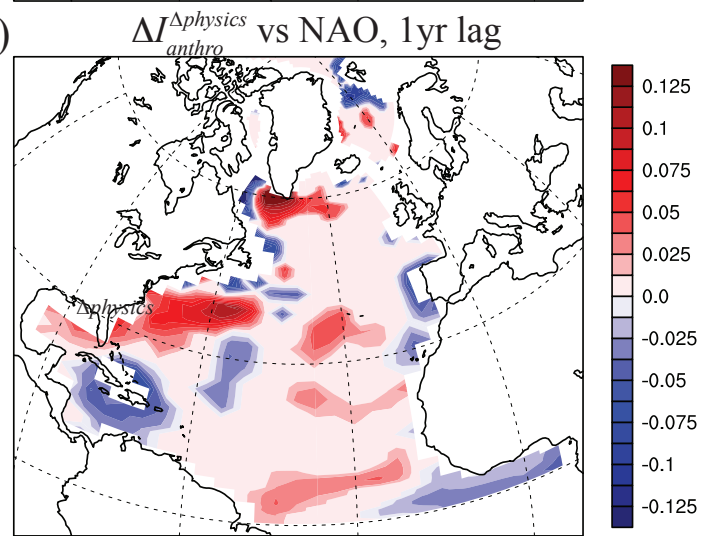

f)

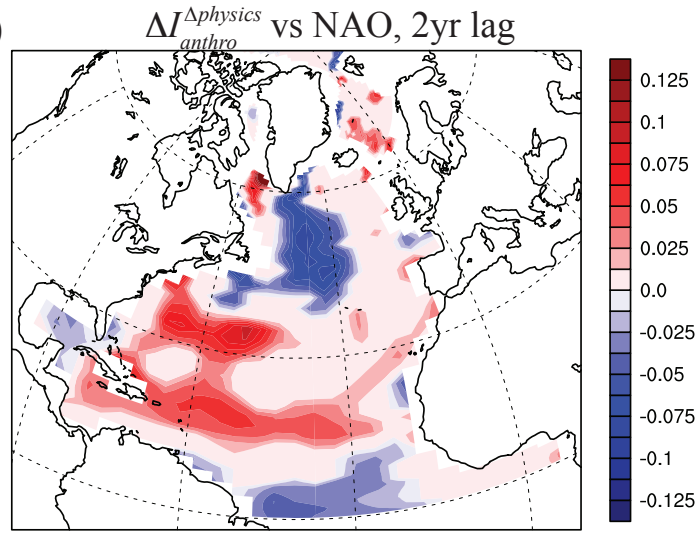

Figure 3.14: Relationship between NAO wintertime index and model maximum MLD, panels a), c), and e), and model $\Delta \mathrm{I}_{\text {anthro }}^{\text {Aphsics }}$, panels b), d), and f). Panels a) and b) show the immediate response to a change in NAO index, panels c) and d) show the relationship for a 1 year lagged response to a change in NAO index and panels e) and f) show the relationship for a 2 year lagged response. $\Delta \mathrm{I}_{\text {anthro }}^{\text {Aphsics }}$ is defined by equation (4). 


\section{Chapter 4:}

\section{The Upper Ocean Sulfur Cycle: Introduction and Methods}

\subsection{INTRODUCTION}

\subsubsection{Overview of the upper ocean sulfur cycle}

The primary precursor of the climatically active trace gas dimethylsulfide (DMS), dimethylsulfoniopropionate (DMSP), is produced in surface waters by marine phytoplankton. DMSP constitutes a significant pool of fixed carbon in the surface ocean, accounting for up to $10 \%$ of phytoplankton cell carbon [Archer et al., 2001; Kiene et al., 2000] and up to $100 \%$ of phytoplankton particulate organic sulfur [Matrai and Keller, 1994]. Many possible roles for DMSP biosynthesis have been suggested including its use 
as an osmotic regulator, an anti-oxidant, a grazing deterrent, and a cryoprotectant. Intracellular DMSP concentrations are species specific and highly variable [Keller et al., 1989; Matrai and Keller, 1994], making community composition and environmental stress important factors for determining DMSP production rates. However, phytoplankton only convert a small fraction of their DMSP to DMS [Niki et al., 2000; Stefels and Dijkhuizen, 1996; Wolfe et al., 2002]. The majority of the intracellular DMSP pool (particulate DMSP, DMSPp) is released as DMSP into the water column through grazing, viral lysis, and cell senescence [Christaki et al., 1996; Hill et al., 1998; Simo et al., 2002; Wolfe et al., 1994]. This dissolved pool of DMSP (DMSPd) is then rapidly cycled by marine bacterioplankton that use DMSP as both a labile sulfur and carbon source. Figure 4.1 depicts DMS and DMSP (DMS(P)) cycling in the upper water column as we understand it today.

Two possible bacterially mediated fates of DMSPd have been identified in surface waters [Cantoni and Anderson, 1956; Kiene and Taylor, 1988]. The DMSP demethylation/demethiolation pathway provides bacteria with both carbon and reduced sulfur compounds, which are easily incorporated into amino acids and cellular biomass. The DMSP cleavage pathway yields an easily accessible 3-carbon compound and the volatile DMS molecule. DMSP cleavage is the only pathway which results in the release of $\mathrm{DMS}_{\mathrm{aq}}$ into the water column. DMS is then available to be consumed by a specialized group of bacteria, decomposed via photolysis, or ventilated to the atmosphere. Due to DMSP demethylation/demethiolation and DMS consumption processes, only a small percentage (1-2\%) of DMSP produced by marine phytoplankton is ventilated to the 
atmosphere as DMS [Bates et al., 1994; Kwint and Kramer, 1996]. Therefore, the magnitude of the release of DMS to the atmosphere strongly depends on the activity of the bacterioplankton community.

DMS concentrations have also been shown to correlate to ultraviolet radiation (UVR) dose and nutrient stress [Harada et al., 2004; Sunda et al., 2002; 2004; Toole et al., 2003]. Toole and Siegel [2004] hypothesize that there are two regimes controlling marine DMS production. They suggest that low-nutrient, subtropical, oligotrophic regions are stress-forced regimes in which DMS production results from physiological stress, such as UV radiation, whereas polar regions are bloom-forced regimes in which DMS production is determined by phytoplankton productivity. To date, no study has explored the differences in the driving chemical and physical mechanisms controlling bacterial DMSP transformations in either of these environments.

Here we focus on open ocean, low-nutrient, oligotrophic regions using the Bermuda Atlantic Time-series Study as a test site to investigate bacterial degradation of DMSPd and DMS production in the open ocean. During a 10 month time-series at the BATS station (February-November), the abundance and expression of key genes involved in the two DMSP degradation pathways and the potential activity of the enzymes involved in bacterial and phytoplankton DMS production were quantified. In order to determine the driving processes behind bacterial DMSPd degradation and bacterial and phytoplankton DMS production, seasonal shifts in these pathways are compared to changes in other components of the sulfur cycle as well as to changes in physical and chemical properties measured on the BATS cruises. 


\subsubsection{Bacterial degradation of DMSPd}

Bacteria play a fundamental role in DMSP cycling [Kiene et al., 2000; Malmstrom et al., 2004a; Pinhassi et al., 2005; Visscher et al., 1992]. The chemical structures of the compounds involved in the two bacterial degradation pathways, DMSP cleavage and DMSP demethylation/demethiolation ${ }^{1}$, are shown in Figure 4.2. The demethylation pathway demethylates/demethiolates DMSP to methanethiol or 3mercaptopropionate whereas the cleavage pathway cleaves DMSP to DMS and acrylate or 3-hydroxy propionate. Field and culture studies indicate that distinct bacterial populations may be responsible for the different DMSP and DMS degradation pathways [Taylor and Gilchrist, 1991; Visscher et al., 1992]. However, members of the Roseobacter group have been shown to possess the ability to both demethylate and cleave DMSP [Gonzalez et al., 1999].

During demethylation, a methyl group is cleaved off of the DMSP molecule resulting in 3-methiolpropionate (MMPA) ${ }^{2}$. MMPA is then demethiolated to form methanethiol (MeSH), which is easily incorporated into cell protein primarily in the form of methionine or cysteine. Alternatively MMPA can be demethylated again to form 3mercaptopropionate (MPA). The DMSP demethylation pathway was first identified in anoxic marine sediments [Kiene and Taylor, 1988] and later identified in aerobic marine bacteria [Taylor and Gilchrist, 1991; Visscher and Taylor, 1994]. Kiene and co-authors

\footnotetext{
${ }^{1}$ The demethylation/demethiolation will be referred to as the demethylation pathway.

2 3-methiolpropionate is also called 3-methylmercaptopropionate.
} 
[1996; 2000b; 2000] suggest that DMSP demethylation is the dominant degradation pathway for DMSPd in marine environments ( $>75 \%$ of DMSPd consumption) and that DMSP is a significant source of both carbon and sulfur for bacterial communities. Other studies show that DMSP degradation supports $50-100 \%$ of bacterial sulfur demands and 0.4-30\% of bacterial carbon demands [Kiene and Linn, 2000a; Simo et al., 2002; Zubkov et al., 2001].

$\alpha$-proteobacteria are particularly active in the cycling of DMSP in both coastal and open ocean environments [Gonzalez et al., 1999; Malmstrom et al., 2004a; Malmstrom et al., 2004b; Vila et al., 2004; Zubkov et al., 2001; 2002]. Roseobacter, a group of $\alpha$-proteobacteria, is an abundant bacterial taxa in surface waters comprising $\sim 5$ $10 \%$ of the bacterial community [Buchan et al., 2005]. Roseobacter strains have been shown to demethylate DMSP and/or cleave DMSP to DMS [Gonzalez et al., 1999; Kiene et al., 1999; Moran et al., 2003]. In 2006, Howard et al. identified the gene (dmdA) responsible for the demethylation of DMSP to MMPA in the Roseobacter strain Silicibacter pomeroyi. Howard et al. concluded that at least $80 \%$ of Roseobacter cells captured in the Sargasso Sea metagenomic database and one third of all bacterioplankton cells possess homologs to $d m d A$. In addition, $40 \%$ of SAR11 cells are believed to have the capacity to demethylate DMSP [Howard et al. 2006]. An analysis of the Global Ocean Sampling database ${ }^{3}$ indicates that the abundance of $d m d A$ is even higher elsewhere in the ocean surface waters, with an abundance of all $d m d A$ clades sufficient for $58 \%$ of sampled cells to harbor this gene [Howard et al. 2008]. These genomic analyses support

\footnotetext{
${ }^{3}$ The Global Ocean Sampling database contains samples from coastal, estuarine, open ocean and freshwater sites from around the globe.
} 
the findings of Malmstrom et al. [2004a; 2004b] who conclude that $\alpha$-proteobacterium, specifically SAR11 and roseobacters, play a major role in DMSP cycling in the Sargasso Sea.

The DMSP cleavage or lyase pathway was first identified in 1956 by Cantoni and Anderson who showed that some marine algae enzymatically cleave DMSP, yielding DMS and acrylic acid. Kiene [1990] identified this process in bacterial samples from coastal seawater. Since then, the ability of bacteria to cleave DMSP has been shown to be widespread in marine environments [Yoch, 2002 and references therein]. Recent studies have identified 3 new bacterial DMS producing genes. Todd et al. [2007] reported the discovery of the gene $(d d d D)$ that encodes for a type III acyl coenzyme A transferase which cleaves DMSP to DMS and 3-hydroxypropionate. $d d d D$ was isolated from the $\gamma$ proteobacterium Marinomonas sp. MWYL1 and is only found in low abundance in coastal regions (2-3 copies per 100,000 reads) in the Gulf of Maine and Bedford Basin off Nova Scotia [E. C. Howard et al., 2008]. A second DMSP cleavage gene, $d d d L$, was isolated from the $\alpha$-proteobacterium Sulfitobacter EE-36 and is believed to encode for a lyase which cleaves DMSP to DMS and acrylate [Curson et al., 2008]. In the Global Ocean Sampling (GOS) database, $d d d L$ is found in only one sample (Punta Cormorant Hypersaline Lagoon Floreana Island) at low abundance (6 copies per 100,000 reads). Most recently, $d d d P$, isolated from the $\alpha$-proteobacterium Roseovarius nubinhibens ISM, was determined to result in DMSP-dependent DMS production [Todd et al., 2009]. dddP is predicted to be a member of the PepP Xaa-Pro aminopeptidase metalloenzyme family, suggesting a third pathway for bacterial DMS production. Unlike $d d d D$ and $d d d L$, which 
are only found with an abundance of $0.2 \%$ and $0.6 \%$ per sampled cell in the GOS database respectively, $d d d P$ is found in the Sargasso database with an abundance of $2.9 \%$ per sampled cell [MA Moran, personal communication]. These abundances are extremely low compared to that of the DMSP demethylation gene ( $d m d A)$, which has an average of 32 copies per 100,000 reads (maximum 57 copies per 100,000 reads) or an abundance of $58 \%$ of sampled cells [Howard et al. 2008]. There are several possible explanations for the low abundances of bacterial DMS producing genes, the simplest being that we have yet to identify the dominant bacterial DMSP cleavage gene. Alternatively, the sampling scheme for the GOS samples, e.g. surface waters collected in February in the Sargasso Sea [Venter et al. 2004], may bias the database such that it does not adequately sample the bacterial population responsible for DMS production. Finally, low abundance genes, which are highly expressed, could still be responsible for significant biogeochemical transformations.

The DMSP lyase enzyme was first purified by de Souza and Yoch [1995] from an anaerobic marine bacterium. Subsequently, this enzyme has been isolated, purified and characterized from a number of marine bacteria and phytoplankton [Nishiguchi and Goff, 1995; Stefels and Dijkhuizen, 1996; vanderMaarel et al., 1996]. To avoid tedious enzyme extractions, Steinke et al. [2000] developed a method to rapidly measure phytoplankton potential DMSP lyase activity by quantifying the accumulation of DMS after the addition of saturating DMSP concentrations to cell extracts. Potential DMSP lyase activity measurements are used in the field as a proxy for the activity of the phytoplankton DMSP lyase pathway [e.g. Harada et al., 2004]. To date, the bacterial 
DMSP lyase/cleavage pathway has not been successfully quantified in environmental samples.

Variations in the relative importance of the two DMSP degradation pathways (cleavage versus demethylation) was termed the 'bacterial switch' by Simó [2001]. Kiene

et al. [2000] hypothesize that regulation between the two competing bacterial transformations of DMSP (the 'bacterial switch') is the dominant factor controlling surface water DMS concentrations. These studies predict that, when the bacterial sulfur demand is high and DMSP concentrations are low, the DMSP demethylation pathway will be the dominant degradation pathway. Alternatively, these studies hypothesize that the DMSP cleavage pathway will be the dominant degradation pathway under carbon limitation, low sulfur demand, or high DMSP concentrations,

\subsection{BERMUDA ATLANTIC TIME-SERIES STUDY (BATS)}

The Bermuda Atlantic Time-series Study (BATS) site is located at $31^{\circ} 40^{\prime} \mathrm{N}$ $64^{\circ} 10^{\prime} \mathrm{W}$. This site is ideal for studying oligotrophic regions as it is easily accessible and a complete suite of chemical and physical parameters has been regularly measured since 1988. In addition, a strong seasonal cycle exists at BATS with summertime characterized by warm surface temperatures, a shallow mixed layer, and increased stratification while wintertime tends to have cooler temperatures and a deep mixed layer [Michaels et al., 1994]. As the hydrographic and biological properties at BATS in the summer mimic conditions expected to occur under a high $\mathrm{CO}_{2}$ atmosphere, seasonal changes in the 
DMSP degradation pathways and DMS production observed at BATS may provide insights into the functioning of the marine sulfur cycle under a high $\mathrm{CO}_{2}$ environment (see Chapter 6: Conclusions).

To determine the role of bacteria in the marine sulfur cycle, this study samples the upper ocean sulfur cycle on 10 monthly cruises to BATS between February and November 2008. Each cruise lasted between 4 and 9 days; exact dates of each cruise are presented in Table 4.1. Ancillary measurements made by BATS scientists and utilized in this study include: temperature $\left({ }^{\circ} \mathrm{C}\right)$, salinity (psu), total organic carbon $(\mu \mathrm{mol} / \mathrm{kg})$, particular organic carbon $(\mu \mathrm{mol} / \mathrm{kg})$, and bacterial cell number (cells/L). This study leveraged a co-occurring, multi-year DMS time-series (PIs: Toole, Dacey and Bates) which collected DMS(P) data on BATS cruises from July 2005 through November 2008. Monthly measurements include total DMSP, DMSPd, and DMS concentrations, DMSPd and DMS consumption rates, and the percentage yield of DMS from DMSPd consumption. To these core measurements, this study added DMSP lyase potential enzyme measurements for the bacterial and phytoplankton size fractions and bacterial DMSP degradation gene abundance and expression. Depth profiles of bacterial carbon demand were also quantified. 


\subsubsection{Sampling Scheme}

\subsubsection{DMSP lyase potential enzyme activity sample collection}

Samples for phytoplankton DMSP lyase potential enzyme activity (DLA) were collected monthly (February-November 2008) at 0 m, 10 m, 20 m, 40 m, 60 m, and 100 m. All samples were collected between $5 \mathrm{AM}$ and $7 \mathrm{AM}$ local time to avoid the influence of diurnal variability (with the exception of September where samples were collected at 3 AM instead due to scheduling difficulties). Immediately after the CTD rosette was retrieved, samples were collected in acid-washed 4 L low-density polyethylene Nalgene carboys using acid washed, medical grade, Dow Corning silicon tubing (containing no phthalates or plasticizers). All acid-washing was done with $10 \%$ Fisherbrand hydrochloric acid. The carboys were gently rinsed 3 times with seawater prior to being filled. Whole water samples were collected for the phytoplankton DLA assay. Filtered water $(<1.2 \mu \mathrm{m})$ was collected for the bacterial DLA assay using an in-line $47 \mathrm{~mm}$ polycarbonate filter holder (Pall Life Sciences) containing a $1.2 \mu \mathrm{m}$ glass fiber filter (Whatman, GF/C). The filter holder was connected directly to the CTD niskin using acid-washed Dow Corning silicon tubing and a gentle flow was maintained to minimize lysis of phytoplankton cells during filtration, which can dramatically increase dissolved DMSP (DMSPd) concentrations. Tests in February and September of 2008 showed a 2 to 7 fold increase in DMSPd concentrations as a result of phytoplankton cell lysis during filtering. The results are displayed in Figure 4.3a. Such increases in DMSPd could result in the induction of bacterial activity between sample collection and analysis. The impact of this increase on bacterial DLA was investigated and is described below in 
section 4.3.2.2.6. While pre-filtering resulted in significant increases in DMSPd concentrations, the resulting concentrations are still only $22-34 \%$ of the particulate DMSP (DMSPp) pool (Figure 4.3a) and several orders of magnitude less than the DMSPd addition during the analysis. All DLA samples were stored inside an artificially lit, temperature-controlled lab until they were processed.

\subsubsection{DNA and RNA collection}

Triplicate samples were collected monthly (February - November 2008) at BATS from $0 \mathrm{~m}, 20 \mathrm{~m}, 40 \mathrm{~m}$ and $60 \mathrm{~m}$ for gene abundance and expression analysis. All samples were collected between $5 \mathrm{AM}$ and $7 \mathrm{AM}$ local time to minimize the impact of diurnal variability. Immediately upon retrieval of the CTD, twelve $4 \mathrm{~L}$ acid-washed lowdensity polyethylene Nalgene carboys were rinsed 3 times and then gently filled to $4 \mathrm{~L}$ from the appropriate niskins. Samples were collected on $47 \mathrm{~mm} 0.2 \mu \mathrm{m}$ polycarbonate filters using $47 \mathrm{~mm}$ in-line polycarbonate filter holders (Pall Life Sciences). Acid washed, medical grade Dow Corning silicon tubing (containing no phthalates or plasticizers) was used to minimize contamination. Samples were filtered at low pressure $(<0.02 \mathrm{~Pa})$ using an aspirator vacuum pump. To minimize sample degradation, the filters were changed every 30 minutes for DNA samples and every 15 minutes for RNA samples. Crimps on the tubing immediately preceding the in-line filter holders minimized water loss during filter changes. After each collection, the filters were immediately flash frozen in liquid nitrogen. Four filters were collected from each carboy. The water remaining in the carboy was then measured using a graduated cylinder and the 
total volume of water filtered for each carboy was calculated. On average, $3.6 \mathrm{~L}$ of seawater was filtered per DNA sample and $2.5 \mathrm{~L}$ of seawater was filtered per RNA sample (Table 4.2).

\subsubsection{Bacterial demand sample collection}

Samples for bacterial carbon demand analysis were collected monthly (FebruaryNovember 2008) at $0 \mathrm{~m}, 10 \mathrm{~m}, 20 \mathrm{~m}, 40 \mathrm{~m}, 60 \mathrm{~m}$, and $100 \mathrm{~m}$ between 5 AM and 7 AM local time. Samples were pre-filtered to remove phytoplankton using an in-line $47 \mathrm{~mm}$ polycarbonate filter holder (Pall Life Sciences) containing a $1.2 \mu \mathrm{m}$ glass fiber filter (Whatman, GF/C). Samples were collected in $100 \mathrm{ml}$ acid-washed polycarbonate Nalgene bottles and immediately processed in a temperature controlled van.

\subsection{METHODS AND METHOD DEVELOPMENT}

\subsubsection{Concentration and Rate Measurements}

DMS concentrations were determined using a modified purge and trap method following Kiene and Service [1991]. Briefly, $4 \mathrm{ml}$ of sample was added to a $14 \mathrm{ml}$ glass serum vial. Sulfur gases were sparged from the water with air or nitrogen gas and trapped in using a Carbopack-X trap in Sulfinert-treated 1/8" OD stainless steel tubing. The trapped gases were analyzed on a gas chromatograph (GC) with a pulsed flame photometric detector (PFPD) and an Alltech AT-Sulfur capillary $.32 \mathrm{~mm}$ ID column. 
The carrier gases were ultra high purity air or nitrogen and calibration was carried out with a permeation system. All samples were analyzed in duplicate. Total DMSP (DMSPt) and DMSPd were quantified monthly at BATS following the protocols described in Slezak et al. [Slezak et al., 2007 and references therein] by A. Neeley and N. Levine. Particulate DMSP (DMPSp) is calculated as the difference between DMSPt and DMSPd. Bacterial DMSPd and DMS consumption rates were determined using the ${ }^{35} \mathrm{~S}$ tracer methods of Kiene and Linn [2000b] by A. Neeley and N. Levine. These methods quantify the turnover rates of the DMSPd and DMS pools by measuring the loss of ${ }^{35} \mathrm{~S}$ DMSPd and ${ }^{35} \mathrm{~S}-\mathrm{DMS}$ from the dissolved and volatile pools, respectively.

Monthly depth profiles of bacterial carbon demand were determined using ${ }^{3} \mathrm{H}$ leucine incorporation following the protocol of Smith and Azam [1992]. Briefly, $1.5 \mathrm{ml}$ of $1.2 \mu \mathrm{m}$ pre-filtered seawater was added to $2 \mathrm{ml}$ siliconized, low-retention, polypropylene, Fisherbrand microcentrifuge tubes. ${ }^{3} \mathrm{H}$-leucine was then added to a final concentration of $20 \mathrm{nM}$ in three seawater samples and one Trichloroacetic acid (TCA) killed control for each depth. Samples were incubated for $4.5 \mathrm{~h}$ in the dark at in situ surface temperatures. Following the incubation period, the three live samples were killed using cold TCA. Particulate matter in the samples was collected through centrifugation and the incorporation of ${ }^{3} \mathrm{H}$ was quantified using the EcoLume scintillation cocktail (Cardinal Health) and a Packard Tri-Carb 2000CA Liquid Scintillation Analyzer. Leucine incorporation was converted to bacterial carbon demand using conversion factors from Carlson et al. [1996]. 


\subsubsection{Potential Enzyme Activity}

The assays used to measure the DMSP cleavage/lyase potential enzyme activity (DLA) for the phytoplankton and bacterial size fractions are described below. While we now believe that at least some bacterial DMS production does not use a typical lyase enzyme, to be consistent with the literature we will refer to the bacterial DMSP cleavage potential enzyme activity as the bacterial DLA. The methods are adapted from Harada et al. [2004] and Steinke et al. [2000] and applied to the bacterial fraction for the first time. Potential enzyme assays measure the enzyme activity of a sample that is not substrate limited, in this case for the substrate DMSP. This provides an estimate of the maximum potential DMS production. In actuality, enzyme activity will be limited by substrate availability. Thus, in order to translate potential enzyme results into meaningful biogeochemical rates, the potential activity must be multiplied by the water column concentrations of the available substrate.

The phytoplankton and bacterial pools are differentiated based on size with the phytoplankton pool defined as the size fraction $>1.2 \mu \mathrm{m}$, and the bacterial pool defined as the size fraction between $0.8 \mu \mathrm{m}-1.2 \mu \mathrm{m}$. The assays for the phytoplankton and bacterial size fractions are similar and so are described together (section 4.3.2.1). The method development and field tests for these two protocols are described in section 4.3.2.2. Significant method development for the second DMSP degradation pathway, DMSP demethylation, was conducted during this study. The method for this pathway was not finalized and so not quantified during this study. A description of the work done on this method is described in Appendix $C$. 


\subsubsection{Phytoplankton and Bacterial DMSP Lyase Potential Enzyme Activity (DLA)}

Phytoplankton and Bacterial DMSP DLA samples were processed in duplicate immediately following collection. The full protocols are provided as Appendices $D$ and $E$. For the phytoplankton size fraction, $500 \mathrm{ml}$ of whole seawater was filtered through an autoclaved $25 \mathrm{~mm} 1.2 \mu \mathrm{m}$ glass fiber filter (Whatman, GF/C) using a polycarbonate funnel filter holder and gentle filtration $(<0.02 \mathrm{~Pa})$. For the bacterial size fraction, approximately $400 \mathrm{ml}$ of the $1.2 \mu \mathrm{m}$ pre-filtered water was filtered through an autoclaved $25 \mathrm{~mm}$ polycarbonate filter using the same filtration system as for the phytoplankton. Bacterial sample volumes were adjusted to keep filter times to approximately $30 \mathrm{~min}$. The protocol following filtration was identical for both size fractions and described below.

The filter was placed in a $14 \mathrm{ml}$ amber glass serum vial and submerged in $1 \mathrm{ml}$ of $200 \mathrm{mM}$ Tris buffer $(\mathrm{pH} 8)$ with $500 \mathrm{mM} \mathrm{NaCl}$. The vial was vortexed briefly, and incubated for 20 minutes in under-way seawater. For the phytoplankton assay, this serves to break-up the filter and lyse the cells. For the bacteria, this step transfers many of the cells to the Tris buffer. Under-way seawater was collected through an inlet system in the ships bow at $\sim 5 \mathrm{~m}$ and so was representative of the in-situ surface water temperature. A constant temperature (within $1{ }^{\circ} \mathrm{C}$ ) was maintained throughout the assay using an underway seawater bath. The starting and ending temperatures were recorded for each sample. Amber serum vials were used to minimize the effect of light on the samples. 
Following the incubation, a saturating concentration of DMSP was added (final concentration $5 \mathrm{mM}$ ) and the vial was immediately crimped. The evolution of DMS in each vial was monitored using a gas chromatograph (GC) with a pulsed flame photometric detector (PFPD), a Carbopack-X trap in Sulfinert-treated 1/8" OD stainless steel tubing, and an Alltech AT-Sulfur capillary .32 mm ID column. Air or nitrogen was used as the carrier gas. Every 2 minutes 15 seconds the vial was vortexed for 5 seconds to equilibrate the headspace with the $1 \mathrm{ml}$ sample. $100 \mathrm{ul}$ of headspace was then extracted using a gas tight syringe and injected into the GC. Five time-points were measured per sample. Two different running modes for the GC-PFPD were tested: 1) samples injected directly onto the column, and 2) samples injected into the carrier gas stream, trapped, and then heated to greater than $220^{\circ} \mathrm{C}$ for desorption prior to being loaded onto the column. The direct inject method allows samples to be processed quickly, at 30 second intervals, but results in broader peaks with lower reproducibility than the trapping method. The trapping method requires a 2 minute 15 second interval between sample injections but is highly reproducible, average standard deviation $(1 \sigma)$ of $5.2 \%$. Therefore, the trapping method was used for this study. Immediately preceding and following the DLA quantification, three sets of five aqueous DMS standards, ranging from $0.5 \mu \mathrm{M}$ to $10 \mu \mathrm{M}$, were run according to the trapping method described above. The standard curve $\mathrm{R}^{2}$ values are better than 0.99 and often better than 0.999 . The average RMS error on the standard curve slope is $0.15 \mu \mathrm{M}$ for standards run with the trapping method on the GCPFPD.

The DLA rate is calculated as: 
$D L A_{\text {PotentialActivity }}=\left[\left(\frac{d D M S}{d t}\right)-\left(\frac{d D M S P_{\text {abiotic }}}{d t}\right)\right] /$ Vol

where $\frac{d D M S}{d t}$ is the slope of the best-fit trend line to the observed [DMS] vs. time, $\frac{d D M S P_{a b i o t i c}}{d t}$ is the correction for the abiotic degradation of DMSP in the assay (see discussion of the blank correction below), and Vol is the volume of seawater filtered. The $\mathrm{R}^{2}$ of the $\frac{d D M S}{d t}$ trend line is typically 0.99 or better (see Table 4.3 for monthly $R^{2}$ values). The potential DLA for each depth is calculated as the average of the duplicate samples. An additional correction is applied to the bacterial DLA samples to account for the effect of the polycarbonate filter on the observed DMS concentrations (see discussion below). The error on the DLA estimate is calculated using error propagation and is based on the standard curve errors, the error in the abiotic DMSP degradation estimate, and the difference between the duplicate samples. Monthly average error in DLA rate and assay temperatures are presented in Table $4.3 b$.

\subsubsection{DMSP Cleavage Potential Enzyme Method Development}

Extensive method development and testing were conducted for the bacterial and phytoplankton DLA assays. Specifically, tests were conducted to determine 1) whether the bacterial cells should be lysed or whole, 2) the optimal filters type for the DLA assays, 3) the optimal protocol for DMS quantification, and 4) the accurate correction for 
abiotic DMSP degradation. In addition, field tests were conducted to quantify procedural errors, specifically looking at the effect of temperature and on-deck waiting time on the measured DLA.

\subsection{Method Development: Whole versus lysed cells for bacterial DLA}

Using a whole cell extract allows for the quantification of the in situ DMSP lyase potential enzyme activity without possible induction of enzyme activity during the assay. The original DLA method developed by Steinke et al. [2000] lyses phytoplankton cells using a Tris- $\mathrm{NaCl}$ buffer and vortexing. This lysis is not stringent enough to lyse bacterial cells (this was verified by microscopy). Therefore, several other lysis methods were tested with the objective of developing a method that resulted in lysed bacterial cells without impacting the enzyme activity. Lysis methods were tested using a culture of Silicibacter pomeroyi, a Roseobacter isolated from coastal seawater [Gonzalez et al., 2003] that both demethylates and cleaves DMSP. As described above (section 4.1.2), roseobacters are thought to be dominant players in the upper ocean sulfur cycle and so a good candidate for method development. The four methods tested were:

1) 10 minutes of bead-beating with Tris- $\mathrm{NaCl}$ buffer

2) 20 minutes incubation at $30^{\circ} \mathrm{C}$ with lysozyme followed by 10 minutes of bead-beating with Tris- $\mathrm{NaCl}$ buffer

3) 3 freeze-thaw cycles in liquid nitrogen

4) 3 minutes of sonicating at $70 \%$ power (sonicate 30 seconds, 1 minute on ice, repeat). 
The French press is commonly used to lyse cells for enzyme analysis. However, this method was not appropriate for the DLA assay as the cells are collected on a filter. Of the methods tested, the bead-beating and sonicating techniques successfully lysed the majority of the bacterial cells (verified by microscopy). Bead-beating plus lysozyme had a slightly higher enzyme activity than bead-beating alone. However, none of the methods allowed for accurate quantification of the potential enzyme activity. Bead-beating plus lysozyme still showed a $93 \%$ decrease in enzyme activity as compared to whole bacterial cells. Sonication resulted in a complete loss of enzyme activity most likely due to denaturating of the enzymes from the heat generated during this process.

To further investigate the effect of the lysis methods on the DMSP lyase enzyme activity, the different lysis methods were applied to phytoplankton cells. While phytoplankton enzymes differ from those contained in bacterial cells, these tests allowed us to determine the potential impact of the lysis methods on DMS producing enzymes. The result was a $20-70 \%$ decrease in phytoplankton enzyme activity as compared to the activity of cells lysed using only the Tris- $\mathrm{NaCl}$ buffer and vortexing. Treatment with lysozyme and incubation at $37^{\circ} \mathrm{C}$ alone does not appear to affect the enzyme activity in phytoplankton indicating that low heat and the lysozyme enzyme do not impact the DMSP lyase enzyme. We believe that bead-beating methods result in decreased enzyme activity through physical damage to the enzymes during lysis. At BATS, the bead-beating plus lysozyme lysis method resulted in a $27 \%$ decrease in bacterial enzyme activity relative to the whole cell activity (BATS July 2008, 20m). 
Our findings indicate that more stringent lysis methods needed to lyse bacterial cells have a significant negative effect on the DMSP lyase enzyme system (in culture samples and at BATS). Therefore, it was decided to use whole (un-lysed) bacterial cells to quantify the bacterial DLA. This decision is supported by research in Andrew Johnston's laboratory (University of East Anglia), which indicates that there are several different bacterial enzyme systems producing DMS from DMSP. The biochemistry of these transformations has not yet been fully elucidated. Therefore, optimal conditions (e.g. anoxia) and potential co-factors (e.g. CoEnzyme A) are unknown. By keeping the cells intact, the impact of these unknowns is minimized. We also hypothesize that the Tris- $\mathrm{NaCl}$ buffer may make the bacterial cell walls more permeable allowing for more efficient transfer of DMSP into the cells (personal communication with R. Kiene).

Proceeding with a 'whole cell' method for the bacterial DLA raises the concern that the high concentrations of DMSP present in the assay may lead to the induction of DMSP related enzymes during the assay. This was tested in culture and in the field at BATS. In culture, the production rate of DMS showed a slight non-linear increase during the first 40 minutes of the assay followed by a significant increase in the rate of DMS production. The exponential increase after 40 minutes indicates significant induction of the DMSP lyase enzyme during the assay in culture samples. However, in the field, the production of DMS during the 20 minute DLA assay was essentially linear (average $\mathrm{R}^{2}=0.977$ ) indicating negligible enzyme induction. This is consistent with our current belief that the response times for oligotrophic microbial systems is $>20$ minutes (M. Sato personal communication). From these tests, we conclude that there is no significant 
induction of bacterial DMSP lyase/cleavage enzymes in field samples during the 20 minute assay used in this study.

\subsection{Method Development: Filter type for DLA assay}

Several different filter types were tested for the bacterial and phytoplankton DLA assays. In whole water tests (no pre-filter), the filter type significantly affected the enzyme activity when phytoplankton cells were present with the highest activity obtained from glass fiber filters, and the lowest activity from polycarbonate and polyethersulfone filters. The decreased activity in these tests most likely is due to lysis of the phytoplankton cells upon impact with the filter. Cell lysis due to impact with the filter is less of a concern for bacteria only samples. Tests indicate that for bacterial samples polycarbonate filters result in slightly higher enzyme activities than nylon filters. Therefore, the decision was made to use glass fiber $(\mathrm{GF} / \mathrm{C})$ filters for the phytoplankton DLA assay and polycarbonate filters for the bacterial DLA assay.

\subsection{Method Development: Accurate quantification of DMS during DLA assay}

Several modifications were made to optimize the quantification of DMS during the DLA assays. Tests were conducted to determine whether $1 \mathrm{ml}$ or $2 \mathrm{ml}$ of Tris-NaCl buffer should be used in the assay. Standard solutions showed no difference between $1 \mathrm{ml}$ and $2 \mathrm{ml}$ standards once corrections were made for differences in liquid and headspace volumes. However, samples with $2 \mathrm{ml}$ of buffer had $13 \%$ lower enzyme rates than 
samples with $1 \mathrm{ml}$ (this difference is just above the measurement error). This lower enzyme rate could be due to the dilution of enzyme and DMSP in the assay. Therefore, in order to accurately measure the potential enzyme activity, $1 \mathrm{ml}$ buffered solutions were used for this study. Before the headspace is sampled, the vials are vortexed for 5 seconds. Tests show that there is no difference in observed DMS concentration between standards vortexed for 5, 10 and 30 seconds. Therefore, we feel confident that vortexing for 5 seconds is sufficient to re-equilibrate the headspace with the DMS produced in the Tris-NaCl buffer.

Bacterial DLA samples were collected on $0.8 \mu \mathrm{m}$ polycarbonate filters as described in section 4.3.2.1. The use of the polycarbonate filter in the assay was shown to impact the measured DMS concentration. Aqueous DMS standards run with polycarbonate filters were $58 \%$ lower than standards run without a filter, see Table 4.4 . This decrease was found to be constant with time (standard deviation of $7 \%$ ) and was reproducible on different GCs. In order to use the same standards for the bacterial DLA assays and the phytoplankton DLA assays, standards were run without a filter and a correction of 0.580 was applied to the standard curves before calculating the bacterial DLA rates. No correction was needed for the phytoplankton DLA rates as the glass fiber filters do not affect the observed DMS concentrations.

\subsection{Method Development: Correction for abiotic DMSP degradation}

Previous researchers [Harada et al., 2004; Steinke et al., 2000] have reported a non-zero blank associated with the phytoplankton DLA assay. This is due to abiotic 
degradation of DMSP to DMS. While these blanks are low compared to typical phytoplankton DLA rates, they can be significant in relation to bacterial DLA rates, particularly during the winter months at BATS. Several tests were conducted to confirm that the non-zero blank was indeed abiotic and that it was not possible to reduce the abiotic signal. For these tests, several different batches of DMSP obtained from Research Plus Inc. in addition to DMSP synthesized by J. Dacey (WHOI) were compared ${ }^{4}$. All showed similar abiotic rates of DMSP degradation indicating that the degradation was not due to a contamination in a single batch of DMSP. To confirm that the non-zero blank was abiotic, both the Tris- $\mathrm{NaCl}$ buffer and DMSP stock were filtered using a Fisherbrand $0.22 \mu \mathrm{m}$ mixed cellulose ester syringe filter and Millipore 100,000 Dalton molecular cutoff spin filter, respectively, to remove any potential contaminating bacteria. The filtering did not decrease the rate of DMSP degradation indicating that the non-zero blank was indeed abiotic. The rate of degradation was shown to be significantly lower in water $(\mathrm{pH}$ 7) than in Tris- $\mathrm{NaCl}$ buffer ( $\mathrm{pH} \mathrm{8).} \mathrm{This} \mathrm{is} \mathrm{consistent} \mathrm{with} \mathrm{the} \mathrm{findings} \mathrm{of} \mathrm{Van} \mathrm{Diggelen}$ et al. [1986], who mention that DMSP is unstable above a pH of 7 and can spontaneously degrade to DMS. The abiotic DMSP degradation is shown to be temperature dependant with a $10^{\circ} \mathrm{C}$ decrease in temperature resulting in a $50 \%$ decrease in abiotic DMSP degradation (Figure 4.4a). The abiotic DMSP degradation rates used to correct the observed phytoplankton and bacterial DLA rates were measured monthly during the BATS time-series at in-situ surface temperatures.

\footnotetext{
${ }^{4}$ We believe that Research Plus Inc and J. Dacey use the same or similar DMSP synthesis methods.
} 


\subsection{Field Test: Impact of temperature on DLA}

Temperature has a significant effect on enzyme activity. Phytoplankton DLA assays have been typically measured at $30^{\circ} \mathrm{C}$. While this assists in inter-comparisons between studies, it makes biogeochemical interpretation very difficult particularly where environmental temperatures vary significantly. In order to approximate the samples' in situ temperature, we ran all samples in under-way seawater collected at $\sim 5 \mathrm{~m}$ through an inlet in the bow of the $R / V$ Atlantic Explorer. This resulted in a $7^{\circ} \mathrm{C}$ temperature change between February and September $\left(20^{\circ}-27^{\circ} \mathrm{C}\right)$. To test the effect of this temperature change on bacterial DLA, we conducted a series of field and culture tests.

The impact of temperature on Roseobacter DLA was tested using a culture of Ruegeria pomeroyi. DMSP (final concentration $150 \mu \mathrm{M}$ ) was added to a culture grown with glucose as the sole carbon source. The culture plus DMSP was allowed to incubate for 1.5 to 1.75 hours to allow the bacteria to respond to the DMSP addition. The culture was then filtered and the DLA was quantified following the protocol described in section 4.3.2.1. During the assay, samples were incubated at four different temperatures $\left(19^{\circ} \mathrm{C}\right.$, $25^{\circ} \mathrm{C}, 30^{\circ} \mathrm{C}$, and $\left.35^{\circ} \mathrm{C}\right)$. The experiment incubated with DMSP for 1.75 hours showed higher DLAs, indicating that there was an increased bacteria response to the addition of DMSP after 1.75 hours as compared to 1.5 hours. This test show a somewhat linear 88$97 \%$ increase in bacterial enzyme activity when the temperature was increased from $19^{\circ} \mathrm{C}$ to $30^{\circ} \mathrm{C}$ (Figure $4.4 b$ ). Increasing the assay temperature for culture samples from $30^{\circ}$ to $35^{\circ} \mathrm{C}$ resulted in a small increase in enzyme activity, $0-15 \%$. This culture study indicates 
that bacterial DLA is strongly temperature dependant with an optimal temperature around $30^{\circ} \mathrm{C}$ for this strain of Roseobacter.

To directly test the effect of temperature on field samples, temperature sensitivity tests were run in February and August (Figure 4.5). Each month, the DLA of identical 40 $\mathrm{m}$ samples was measured in duplicate at two temperatures, $\sim 20^{\circ} \mathrm{C}$ and $\sim 30^{\circ} \mathrm{C}$. Specifically, February samples were run at $20^{\circ} \mathrm{C}$ and $30^{\circ} \mathrm{C}$ and August samples were run at $21^{\circ} \mathrm{C}$ and $27^{\circ} \mathrm{C}$. In February, the $30^{\circ} \mathrm{C}$ DLA was $85 \%$ lower than the $20^{\circ} \mathrm{C}$ rate and within error of zero. However, the $20^{\circ} \mathrm{C}$ rate had large error bars making it not significantly greater than zero, therefore the February temperature test was deemed inclusive. In August, the bacterial DLA increased by $50 \%$ when the temperature was increased from $21^{\circ} \mathrm{C}$ to $27^{\circ} \mathrm{C}$. These tests indicate that the observed seasonal differences in the bacterial DLA (high in the summer, low to zero in the winter) are not simply due to changes in water temperature but rather reflect changes in enzyme abundance. If temperature was solely responsible for the observed changes, the $30^{\circ} \mathrm{C}$ test in February would have shown a high DLA similar to the rates observed in August when the in-situ temperature was $27^{\circ} \mathrm{C}$. Similarly, the $21^{\circ} \mathrm{C}$ test in August should have shown very little to no enzyme activity similar to the rates observed in February when the in situ temperature was $21^{\circ} \mathrm{C}$. Unfortunately, similar tests were not done for the impact of temperature on the phytoplankton DLA. These results have significant implications for the interpretation of DLA results. The large temperature dependence of the DLA assay suggests that all DLA assays should be run at in situ temperatures to best approximate the environmental enzyme rate. 


\subsection{Field Test: The impact of on-deck waiting time on DLA}

Each set of bacterial samples takes 1 hour 15 minutes to 1 hour 25 minutes to run, depending on filter time. The phytoplankton duplicates take 50 minutes to run. Therefore, processing the entire 6 depth profile for bacterial and phytoplankton DLA took approximately 6 hours (samples were overlapped such that the next set was being filtered and incubated while the previous set was being analyzed on the GC), requiring that DLA samples sat in the lab for several hours prior to analysis. Several precautions were taken to minimize the impact of this waiting time on the monthly DLA profiles. In addition, to understand the impact of the 'on-deck waiting time', a series of tests were conducted in the field.

To avoid a systematic impact on the depth profiles, the samples were run in a random order: $40 \mathrm{~m}, 0 \mathrm{~m}, 20 \mathrm{~m}, 60 \mathrm{~m}, 10 \mathrm{~m}$, and $100 \mathrm{~m}$. The same order was used every month. To analyze the impact of the time delay between the first sample and the last sample, the first sample depth $(40 \mathrm{~m})$ was re-run at the end of the analysis. This was tested for both the bacterial DLA and the phytoplankton DLA five times during the timeseries (February, May, July, September, and November). The results are displayed in Figure 4.6. The was no significant difference in February and May between the $40 \mathrm{~m}$ bacterial DLA measured immediately after sample collection and the rate measured 7 hours later. July and November showed a $30 \%$ and $40 \%$ decrease in bacterial DLA, respectively, between the first measurement and the subsequent measurement 7 hours later. In July this change is almost within the measurement error. Interestingly, 
September showed a $30 \%$ increase in bacterial DLA between the first measurement and the second measurement. The phytoplankton DLA did not significantly change in 7 hours in February. May and July showed a $40 \%$ and $14 \%$ increase in phytoplankton DLA, respectively, over the course of 7 hours. September and November showed a $12 \%$ and $25 \%$ decrease in phytoplankton DLA, respectively, over the 7 hours between measurements. These tests show that the time delay between the first and last sample has a substantial effect that is unfortunately not systematic and therefore difficult to correct for. This delay was unfortunately unavoidable and the results from these tests were taken into consideration during the analysis of the DLA depth profiles (Chapter 5) such that only changes in DLA greater than $30 \%$ are considered robust. However, the structure of the depth profiles is not related to the order in which the samples were run indicating that the time delay in sample processing did not significantly alter the shape of the observed depth profiles.

The change in DMSPd in the $4 \mathrm{~L}$ sample carboys over $9 \mathrm{~h}$ was also monitored in September (Figure 4.3b). Over a nine hour period the DMSPd concentration in the $40 \mathrm{~m}$ $1.2 \mu \mathrm{m}$ pre-filtered carboy (for bacterial DLA) decreased $60 \%$ from $6.5 \mathrm{nM}$ to $2.3 \mathrm{nM}$. There was no significant change in the DMSPd concentration in the $40 \mathrm{~m}$ whole water (phytoplankton DLA).

\subsection{Field Test: DMS consumption in bacterial DLA assay}

The consumption of DMS by members of the bacterial community is well established [e.g. del Valle et al., 2007]. Therefore, there is concern that DMS 
consumption may be occurring in the bacterial DLA assays. To test this, saturating concentrations of DMS $(3 \mu \mathrm{M})$ were added to the assay in place of DMSP (see Appendix E, step 6), and the change in DMS concentration was measured over a 20 min period. DMS consumption was observed during these tests, and this consumption was shown to decrease with the addition of dimethyl disulfide (DMDS), commonly used to inhibit DMS consumption during field experiments. However, the rate of DMS consumption was small compared to the rate of DMS production in the assay, $0-15 \%$ in November (average 5\%) and $0-25 \%$ in October (average 12\%). The rate of DMS consumption is approximately equal to the average error for the DLA measurements (9\%). The profile of DMS consumption measured in November 2008 using the bacterial potential enzyme approach was consistent with radioisotope DMS consumption measurements: peak consumption observed at $10 \mathrm{~m}$. However, the DMS consumption profile measured in October was not consistent with the radioisotope profile: there was no significant structure seen in the profile measured using the potential enzyme approach in October. Because DMS consumption profiles quantified with the DLA assay and radioisotopes were not consistently correlated, the radioisotope measurement could not be used to correct for DMS consumption during the DLA assay. Therefore, no correction for DMS consumption in the DLA assays was made. However, this has a negligible impact on the results as DMS consumption in the assay is small relative to DMS production.

DMDS was not added to the enzyme assays to inhibit the consumption of DMS as tests showed that it also inhibited the production of DMS from DMSP. These tests raise significant concern over the validity of the ${ }^{35} \mathrm{~S}$-DMS yield assay used by many 
researchers as DMDS is routinely added to these experiments. However, further work is needed to confirm the inhibition of DMS production by DMDS.

\subsubsection{Gene Expression and Abundance}

The expression (RNA) and abundance (DNA) of DMSP degrading genes were quantified for the 10 month BATS time-series. The extraction and quantification protocols and method tests are described below.

\subsubsection{DNA extraction: method development}

DNA samples were transported back to WHOI in liquid nitrogen and were stored at $-80^{\circ} \mathrm{C}$ until they were extracted in February, 2009, using a phenol- chloroform extraction protocol modified from R. Parsons, BIOS [personal comm.]. The full protocol is provided as Appendix F. Briefly, the four filters collected for each sample were submerged in $5.5 \mathrm{ml}$ of sucrose lysis buffer and sodium dodecyl sulfate (SDS). Proteinase $\mathrm{K}$ was also added to assist in cell lysis. The solution was incubated at $37^{\circ} \mathrm{C}$ for $30 \mathrm{~min}$ and then $55^{\circ} \mathrm{C}$ for $30 \mathrm{~min}$. The supernatant was transferred to a new $15 \mathrm{ml}$ tube where the DNA was extracted using two phenol-chloroform-isoamyl alcohol extraction steps followed by a chloroform-isoamyl alcohol extraction step. The DNA was precipitated over night at $-20^{\circ} \mathrm{C}$ with isopropanol and ammonium acetate. The precipitated DNA was re-suspended in 1xTE buffer and transferred to a $2 \mathrm{ml}$ tube where it was re-precipitated using isopropanol and ammonium acetate. Finally, the DNA was washed with $80 \%$ ethanol and the dried pellets were stored at $-80^{\circ} \mathrm{C}$. Four samples 
(February 20mB, March 20mA, April 40mC, and May 60mC) were lost during the extraction due to cracked tubes resulting from the high centrifugation during the precipitation step. Prior to analysis, the DNA samples were re-suspended in $500 \mu \mathrm{l}$ of nuclease free water and quantified using the PicoGreen assay following the manufacturer's protocol. Sample concentrations ranged from $0.71 \mathrm{ng} / \mu \mathrm{l}$ to $14.7 \mathrm{ng} / \mu \mathrm{l}$. The average percent deviation between the biological triplicates, $1 \sigma$ divided by concentration normalized to volume of seawater filtered, was $21 \%$ with a range of $1 \%$ to 59\%. The significant variation observed between the biological triplicates is attributed in part to sample heterogeneity and in part to differences in extraction efficiency between the samples.

The phenol- chloroform extraction protocol was chosen as it provides high yields, good purity, and good reproducibility as compared to two other DNA extraction protocols.

1) MoBio Ultra Clean Soil DNA kit: The Ultra Clean Soil DNA kit was extensively tested, however, despite many modifications to the protocol, the yields were very low as compared to a phenol-chloroform extraction. The following modifications were tested to improve cell lysis: filters were cut prior to bead-beating with a sterile razor; the filters were flash frozen in liquid $\mathrm{N}_{2}$ and then ground using a glass stirring rod; an alternative lysis buffer (sodium dodecyl sulfate (SDS) and sodium chloride $(\mathrm{NaCl})$ ) was added to the bead-beating tubes; and the samples were heated $\left(65^{\circ} \mathrm{C}, 5\right.$ minutes $)$ during the lysis step. To reduce salt contamination, a phosphate buffer wash step was tried prior to bead-beating. Finally, the protein precipitation incubation step was 
extended and conducted at $-20^{\circ} \mathrm{C}$. None of these modifications significantly improved the extraction yield. We believe the source of the low yields for this kit result from inefficient binding of the DNA by the kit's spin filter. A test was conducted where DNA extracted using phenol-chloroform was loaded onto the Ultra Clean spin filter and eluted following the kits protocol. The result was only a 5-10\% recovery (90\% loss).

2) Quiagen DNeasy Blood and Tissue Kit: In a comparison to the phenolchloroform extraction method, the Quiagen kit was found to have low yields and poor reproducibility [R. Parsons, per. comm.]. The kit did result in better purity, however further modifications were made to the phenol-chloroform after this test was conducted which aimed to increase the purity of the extracted DNA (R. Parsons, per. comm.).

The phenol- chloroform extraction method was extensively tested both at WHOI (N. Levine) and at BIOS (R. Parsons). Two different lysis methods were tested: 1) beadbeating with $\mathrm{SDS}$ and $\mathrm{NaCl}$ (protocol from $\mathrm{M}$. Coolen, WHOI) and 2) sucrose lysis buffer with proteinase K (protocol from R. Parsons, BIOS). No significant difference in purity, yield or amplification (PCR) was seen between these two methods. As the sucrose lysis buffer is routinely used at BATS, this method was chosen.

The centrifugation speed for the precipitation step was tested to determine if it was necessary to spin at high speeds to efficiently recover the DNA. Two speeds were tested, 10,000xg and 4,500xg. High centrifugation $(10,000 \mathrm{xg})$ resulted in a higher yield and increased purity and so was used in the protocol. Due to the volume of lysis buffer needed to fully submerge all four filters (one sample $=$ four filters), we decided to perform the extractions in $15 \mathrm{ml}$ polypropylene tubes instead of $2 \mathrm{ml}$ tubes. While this 
decreases the centrifugation speed used in the precipitation step which could decrease yield, it also decreases the number of required precipitation steps from 3 to 2 which increases yield as sample is lost with each precipitation step. A speed of 10,000 x $\mathrm{g}$ for the precipitation step is used in several other protocols, therefore, $15 \mathrm{ml}$ extractions spun at $10,000 \mathrm{x} \mathrm{g}$ were used in order to maximize recovery rates.

A second phenol-chloroform-isoamyl alcohol extraction step was added to increase the purity of the DNA. In addition, precipitation with isopropanol (instead of ethanol) and ammonium acetate (instead of sodium acetate) was used to reduce the coprecipitation of salts and reduce the amount of protein co-precipitation (R. Parsons, per. comm.). Finally, a comparison between homemade phenol-chloroform-isoamyl alcohol and store-bought (Sigma Aldrich) showed no noticeable difference in the quantity and purity of the DNA (R. Parsons, per. comm.).

\subsubsection{RNA extraction: method development}

The RNA samples were extracted either on-board the $R / V$ Atlantic Explorer or at the Bermuda Institute of Ocean Sciences typically within 5 days of collection, with a maximum of 30 days between collection and extraction. Samples were stored in liquid $\mathrm{N}_{2}$ prior to extraction. Extractions were carried out in a portable Plexiglas RNA extraction hood (Figure 4.7) that provided quasi-laminar flow of HEPA filtered air and was thoroughly cleaned using ethanol and RNase-Zap (Ambion). The RNA extraction protocol uses the Quiagen RNeasy Mini Kit and was adapted for environmental samples [M.A Moran, personal comm]; the full protocol is provided as Appendix G. Briefly, $2 \mathrm{ml}$ 
bead-beating tubes were prepared using $0.2 \mathrm{ml}$ of $0.1 \mathrm{~mm}$ zirconia beads, three $3.5 \mathrm{~mm}$ soda lime glass beads, $500 \mu \mathrm{l}$ RLT buffer (RNeasy Mini Kit) and $5 \mu 1 \beta$-mercaptoethanol. The filters were removed from liquid nitrogen and were immediately added to the beadbeating tubes (one filter per tube). The samples were then shaken for 10 minutes using a Vortex Genie and a $2 \mathrm{ml}$ tube adaptor (MoBio). The supernatant was then combined with $70 \%$ ethanol and passed several times through a 20 gauge needle to shear the DNA. The material from the four filters collected per sample was then combined onto a single RNeasy spin column. The RNA was washed and eluted using the RNeasy "Plants and Fungi” protocol steps 6-12. An on-column DNA digestion step using Quiagen's RNasefree DNase kit was added after the first wash step to decrease DNA contamination. Following extraction, the samples were flash frozen in liquid nitrogen and transported back to WHOI where they were stored at $-80^{\circ} \mathrm{C}$. Three samples could not be used in the analysis, March 20C, March 60C and November 60A, because one of the four filters was compromised or lost therefore making the volume quantification inaccurate. These three samples and July 60C were used to test the reverse-transcriptase quantitative polymerase chain reaction protocol (RT-qPCR) as described below.

Prior to quantification, a second DNA digestion was performed using Ambion's TURBO-DNA free kit and the samples were quantified using Invitrogen's RiboGreen assay (for both procedures the manufacturer's protocol was followed). Finally, the volume of all samples was brought up to $55 \mu$ using nuclease free water. RNA concentrations in samples ranged from $0.52 \mathrm{ng} / \mu \mathrm{l}$ to $21.3 \mathrm{ng} / \mu \mathrm{l}$. The average percent deviation between the biological triplicates, $1 \sigma$ divided by concentration normalized to 
volume of seawater filtered, was $26 \%$ with a range of $1 \%$ to $77 \%$. As mentioned above, this large variation in sample concentration per liter filtered is attributed to sample heterogeneity and to variability in the extraction efficiencies.

Several tests were conducted on the RNA extraction protocol to maximize yield and allow for the samples to be extracted at sea.

- Samples extracted with and without the DNA digestion step were run on an argose gel to confirm the absence of DNA in the DNase-treated samples. This was confirmed with polymerase chain reaction (PCR) test on the DNase-treated samples. Reverse-transcribed samples showed amplification of DMSP related genes $(d m d A)$ where as non-reverse-transcribed samples showed negligible amplification indicating the absence of contaminating DNA.

- The addition of a second elution step results in a $30 \%$ increase in sample recovery without affecting the sample purity, as measured by the ratio of sample absorbance at $260 \mathrm{~nm}$ and $280 \mathrm{~nm}$. (A low 260:280 ratio indicates the presence of contaminating protein in the sample.)

- Shearing resulted in a significant increase in the ratio of sample absorbance at 260 $\mathrm{nm}$ and $230 \mathrm{~nm}$ and a slightly higher RNA yield. (Similar to 260:280 ratio, a low 260:230 ratio indicates the presence of contaminating organics in the sample.)

- The use of polycarbonate filters resulted in a slightly higher yield than polyethersulfone filters. There was no significant difference with the use of 25 $\mathrm{mm}$ versus $47 \mathrm{~mm}$ polycarbonate filters. Therefore, $47 \mathrm{~mm}$ polycarbonate filters were used for this study. 
- Bead-beating in a $15 \mathrm{ml}$ versus a $2 \mathrm{ml}$ tube did not significantly affect the yield or purity of the RNA as measured by the $260: 280$ and $260: 230$ ratios. Therefore, 2 $\mathrm{ml}$ tubes were chosen for this study to allow for a greater number of samples to be processed at one time (the bead-beating adaptor can fit $615 \mathrm{ml}$ tubes or $122 \mathrm{ml}$ tubes).

- The yield and purity of the RNA, as measured by the 260:280 and 260:230 ratios, were not affected by centrifuging at room temperature as opposed to $4^{\circ} \mathrm{C}$ during the extraction protocol. This allowed for extractions to be conducted at sea using a small, non-refrigerated, Eppendorf centrifuge.

\subsubsection{Quantitative PCR: Inhibition}

Quantitative polymerase chain reaction (qPCR) analysis uses oligonucleotide primers to amplify specific DNA segments present in the sample. The amount of DNA present in the sample is monitored using the florescent SYBR green dye, which fluoresces only when bound to double-stranded DNA. With each cycle, the amount of DNA present in the sample doubles and the florescence in each well increases proportionally with the amount of DNA. This can then be related back to the number of starting copies of the segment using standards with known copy numbers. This assay hinges on the assumption that the standards and samples amplify with the same efficiency: during each cycle the same fraction of DNA segments are amplified thereby increasing the number of segments present in the reaction at the same rate for standards and samples. The amplification efficiency for qPCR is defined as: 
$\%$ Efficiency $=\left(10^{-1 / \text { slope }}-1\right) \times 100 \%$

(2)

where the slope is the slope of the standard curve, and an efficiency of $100 \%$ indicates that the starting template was effectively doubled during each PCR cycle. An efficiency less than $100 \%$ could be due to several factors, the primary ones being; inhibition of the polymerase chain reaction by contamination in the sample, or inefficient binding of the primers to the target DNA due to poor primer design or sub-optimal reaction conditions. The most troubling is contamination in the sample, as this can be highly sample dependant and cannot be corrected with standards.

Both the RNA and DNA samples from BATS showed significant inhibition in qPCR in initial experiments. In the DNA samples, this inhibition most likely was caused by remnant phenol, added during the extraction, and organics present in the original samples. No phenol was used in the RNA extractions, so inhibition in these samples is most likely due to remnant organics from the original samples. We were able to completely relieve the inhibition in both the RNA and DNA samples with the addition of either molecular grade bovine serum albumin (BSA, New England Biolabs) or T4 bacteriophage gene 32 protein (T4gp32, Roche Diagnostics GmbH). These two compounds are thought to bind to organics in the sample allowing for the PCR to proceed uninhibited [Kreader, 1996]. A BSA gradient (final concentration $300 \mathrm{ng} / \mu \mathrm{l}$ to 1000 $\mathrm{ng} / \mu \mathrm{l}$ in $25 \mu \mathrm{l}$ reaction volume) run with the $\mathrm{D} / 3$ primer set was used to determine the concentration needed to relieve the inhibition in the DNA samples. A final concentration of $500 \mathrm{ng} / \mathrm{ul}$ was selected. The relief of inhibition in DNA samples was confirmed by 
spiking a standard curve (1/10 serial dilutions) with $3 \mu$ of a BATS DNA composite (June 2007, 0m and 10m). The efficiency (equation 2) for the spiked standard curve was the same as the curve without environmental DNA indicating that $500 \mathrm{ng} / \mu \mathrm{l}$ of BSA provided complete relief from the contaminating organics in the samples. Similarly, BSA appeared to relieve much of the inhibition in the RNA samples. Due to limited sample material, a gradient could not be run for the RNA samples. However, a spiked standard curve showed complete relief from inhibition using a final BSA concentration of 500 ng/ $\mu 1$. The effect of the T4gp32 was also tested on the RNA samples as previous work suggested that the T4gp32 also assists in reverse-transcription resulting in higher cDNA yields [Chandler et al., 1998]. T4gp32 and BSA showed the same relief of inhibition in qPCR, as determined by spiking standard curves with environmental RNA, however tests indicated that T4gp32 might improve the reverse transcription (RT) of our samples and so we chose to use T4gp32 in our RT-qPCR assay. A final T4gp32 concentration of 10 ng/ $\mu$ l was used based on work by M. Bowles, UGA [unpublished.]. This concentration is consistent with the one used by Chandler et al. [1998].

\subsubsection{Quantitative PCR: Primer Design and Selection}

Primers for the DMSP demethylation gene $(d m d A)$ were designed and extensively tested by V. Varaljay in the Moran lab at the University of Georgia, Athens [Varaljay et al., submitted]. Five $d m d A$ clades were identified in the Global Ocean Sampling (GOS)

database; A, B, C, D, and E. For this study, we focus on the non-degenerate primer sets 
designed to target seven subclades $(\mathrm{A} / 1, \mathrm{~A} / 2, \mathrm{~B} / 3, \mathrm{C} / 2, \mathrm{D} / 1, \mathrm{D} / 3$, and $\mathrm{E} / 2)$. An iterative approach was used to maximize specificity of the primer sets [Varaljay et al., submitted]. The products from environmental samples using these primers were confirmed with 454 sequencing [Varaljay et al., submitted]. We are confident that these primers are specific for the $d m d A$ subclades for which they were designed.

Primers for $d d d D, d d d L$, and $d d d P$ were designed by E. Howard in the Moran lab at UGA based on sequences in the GOS database. A preliminary PCR test with BATS DNA showed that $d d d P$ and $d d d D$ were both present in the BATS samples [I. Tigner, UGA unpublished]. However, a double band appeared for the $d d d D$ primer suggesting non-specific amplification. The $d d d P$ primer produced a clear, well defined, bright band indicating that the gene was present in significant abundance in the BATS samples and that the primer set was specific for the $d d d P$ gene. The $d d d P$ product was confirmed through sequencing. The results for $d d d L$ were inconclusive- the PCR product band was faint and poorly defined indicating either a lack of product or non-specific priming. Based on these tests, we concluded that $d d d P$ was the most probable DMS producing gene, of those identified to-date, in the Sargasso Sea. Therefore, $d d d P$ was chosen for expression and abundance quantification.

The qPCR conditions were optimized for each primer set by V. Varaljay. A/1 and D/1 standard clones were made by E. Howard from DNA collected at the Sapelo Island Microbial Observatory using the TOPO TA Cloning® kit (Invitrogen) and the PCR 2.1 vector. The D/3 standard clone was made by V. Varaljay from environmental DNA collected at Monterey Bay also using the TOPO TA Cloning ${ }^{\circledR}$ kit (Invitrogen) and the 
PCR 2.1 vector. $\mathrm{A} / 2, \mathrm{C} / 2$, and $d d d P$ standard clones were made by $\mathrm{V}$.Varaljay from BATS DNA using the TOPO TA Cloning ${ }^{\circledR}$ kit (Invitrogen) and the PCR 4.0 vector. Standard clones were quantified based on length of amplicon insert and concentration of the clone extract.

Variations in gene abundance at BATS were determined for five of the eight $d m d A$ subclades. The primer sets were selected based on the results of a mini time-series which analyzed the subclade abundance at $0 \mathrm{~m}$ and $40 \mathrm{~m}$ for 5 months: February, April, June, August, and October were analyzed for subclades A/1, D/1, D/3, and C/2, and March, May, July, September, and November were analyzed for subclades A/2, B/3, and E/2. To minimize sample loss, a single biological triplicate was run as a single replicate. While this does not provide a rigorous estimate of the abundance of these subclades, it does allow us to determine the order of magnitude of the clade abundances at BATS and therefore select the most dominant clades. Standards and no-template controls were run for each primer set. Subclades $\mathrm{C} / 2, \mathrm{D} / 1$, and $\mathrm{D} / 3$ were the most abundant clades and so were chosen for further analysis. Subclades $A / 2$ and $B / 3$ were the next most abundant and showed approximately the same abundance in Sargasso Sea DNA. However, the cursory picture painted by the mini time-series indicated that subclades $\mathrm{A} / 1$ and $\mathrm{A} / 2$ showed significant differences in seasonal variability. Therefore, it was decided to choose subclades $\mathrm{A} / 1$ and $\mathrm{A} / 2$ for further analysis in order to compare the two clade $\mathrm{A}$ subclades. In addition, clade $\mathrm{A}$ is believed to be comprised primarily of roseobacters, which biogeochemical studies have shown to be dominant players in upper ocean sulfur cycling [Malmstrom et al., 2004a; Malmstrom et al., 2004b]. 
Due to limited template, only four subclades could be analyzed for gene expression: $d d d P$ and three $d m d A$ subclades. Again, due to the known importance of roseobacters in sulfur cycling, it was decided to analyze the expression of clade A. Subclade A/1 was chosen over A/2 due to its higher abundance. In addition, the two most abundant subclades, $\mathrm{D} / 1$ and $\mathrm{D} / 3$, were selected. Subclade $\mathrm{C} / 2$ was not selected because it showed lower seasonal variability than the other subclades and lower expression in a preliminary test.

\subsubsection{Quantitative PCR: Sample Processing}

In order to reduce sample degradation, every effort was made to minimize the number of freeze-thaw cycles experienced by the nucleic acid. DNA and RNA samples went through two freeze-thaw cycles. After extraction, DNA samples were frozen and then:

Thaw 1) Samples were re-suspended, quantified, and aliquoted,

Thaw 2) Samples were analyzed.

Similarly, after extraction, RNA samples were frozen and then:

Thaw 1) Samples were DNase treated, quantified, and aliquoted,

Thaw 2) Samples were analyzed.

The RNA samples were kept on ice at all times again to minimize degradation. Samples were aliquoted into 96 well plates using an Eppendorf epMotion robot. This allowed many identical plates to be made quickly and accurately thereby minimizing pipetting 
error and the amount of time that samples remained un-frozen and susceptible to degradation.

All qPCR analyses were done on a BioRad iCycler. The protocols were optimized by V. Varaljay and are given in Appendix $H$. Gene abundance was quantified using the BioRad's iQ SYBR Green Supermix following the manufacturer's protocol with $3 \mu \mathrm{l}$ of substrate and $2.5 \mu \mathrm{l} \mathrm{BSA}$ (final concentration $500 \mathrm{ng} / \mu \mathrm{l}$ ). Technical duplicates (same sample) of biological triplicates (samples collected from the same time and depth but processed independently) were analyzed yielding 6 reactions per sample or 240 reactions per time-series. Gene expression was quantified with BioRad's iScript One-Step RT-PCR with SYBR Green kit following the manufacturer's protocol with 5 $\mu \mathrm{l}$ of substrate and $2.5 \mu \mathrm{l} \mathrm{T4gp32} \mathrm{(final} \mathrm{concentration} 10 \mathrm{ng} / \mu \mathrm{l}$ ). Due to limited template, technical duplicates of biological duplicates were analyzed so that some primer sets were run with biological triplicates $\mathrm{A}$ and $\mathrm{B}$, some with $\mathrm{A}$ and $\mathrm{C}$, and some with $\mathrm{B}$ and $\mathrm{C}$. To confirm the absence of contaminating DNA in the RNA samples, a reverse-transcriptase enzyme (-RT) control was run for each sample with each primer set. ${ }^{5}$ Again due to limited template, single replicates of biological duplicates were run for the -RT samples.

A six dilution standard curve ranging from $\sim 10^{2}-10^{7}$ copies per $\mu$ l for abundance samples and either $\sim 10^{1}-10^{6}$ or $\sim 10^{0}-10^{-5}$ copies per $\mu$ for expression samples was run in duplicate for each plate. The standard clones were made from environmental samples, as

\footnotetext{
${ }^{5}$ During PCR, only DNA is amplified. Therefore, it is necessary to reverse-transcribe the RNA to cDNA before running the PCR. By omitting the reverse-transcriptase enzyme the RNA is not converted to cDNA and so the only template for PCR in the sample is contaminating DNA. The lack of amplification in a -RT sample demonstrates the absence of contaminating DNA in the sample.
} 
described above, and the dilution series was conducted with the Eppendorf epMotion robot to minimize pipetting error. No-template controls were also run on every plate. ${ }^{6}$ For each plate, a master-mix was made up containing the SYBR Supermix, forward and reverse primers, inhibition reagent, water and reverse-transcriptase enzyme (for RTqPCR). The Eppendorf epMotion robot was then used to pipette the master-mix into the pre-aliquoted 96 well plate containing the samples, standards, and no-template controls. Finally, the plate was mixed briefly using the Eppendorf MixMate, centrifuged, and loaded into the iCycler.

\subsection{DISCUSSION}

\subsubsection{Limitations of the potential enzyme assay}

The potential for DMS production by both phytoplankton and bacteria is quantified in this study using the potential enzyme assay. The limitations of these methods are important to recognize. As discussed above, the potential enzyme assay measures the non-substrate limited activity of the enzymes. In actuality, the production of DMS is dependent not only on the amount of enzyme present in the sample but also on the available concentration of DMSP and the physical properties of the water column, such as the in situ water temperature. Therefore, relating a measured DLA rate back to an in situ rate of production is non-trivial. For this study, all potential enzyme assays

\footnotetext{
${ }^{6}$ No-template controls are the blank measurement for qPCR where water is added to the reaction instead of sample
} 
were run in under-way seawater and therefore at in situ surface temperatures. While this is an improvement over the standard method of running these assays at $30^{\circ} \mathrm{C}$, surface temperatures are significantly warmer than the temperature at $100 \mathrm{~m}$ (the depth of our deepest sample). Temperature was shown to have a significant impact on the potential enzyme activity with lower temperatures producing lower DLA rates (section 4.3.2.2.5). Therefore, the DLA rates for the deeper samples may be greater than the in situ rates simply due to the temperature at which the assay was run.

As bacteria do not synthesize DMSP, in situ bacterial enzyme activity is limited by the available DMSP in the dissolved pool. In order to convert the measured bacterial DLA to a more meaningful biogeochemical value, we multiply the DLA rate by the water column DMSPd concentration. However, this does not take into consideration the transport of DMSP across the cellular membrane that may limit intracellular concentrations of DMSP or may concentrate DMSP inside the cell. In addition, several different bacterial enzyme systems that cleave DMSP to DMS have been identified [Curson et al., 2008; Todd et al., 2009; Todd et al., 2007]. The biochemical pathways for each of these enzyme systems have not been fully elucidated and so the necessary cofactors for these enzymes remain undetermined. Therefore, while the bacterial DMSP cleavage enzymes are not limited by DMSP in the potential enzyme assay, they may be limited by an unknown co-factor. Finally, we were unable to determine if the bacterial DLA assay quantifies the activity of all types of bacterial DMSP cleaving enzymes. Therefore, this assay may preferentially quantify one enzyme type. 
Phytoplankton DMS production is believed to be carried out by phytoplankton groups that have high levels of intracellular DMSP. As not all DMSP producers contain DMSP lyase enzymes [Niki et al., 1997], the intracellular concentration of DMSPp in DMS producing cells may not be linearly related to total water column DMSPp concentration. Therefore, we do not multiply the phytoplankton DLA activity by the observed DMSPp concentration. However, it is possible that intracellular phytoplankton DMSP concentrations are limiting for phytoplankton DMSP lyase enzymes yielding in situ phytoplankton DMS production rates that are lower than the estimated rate from the DLA assay. In addition, phytoplankton cells in the potential enzyme assay are lysed (see discussion above). The impact of disrupting the phytoplankton cellular machinery on the measured enzyme activity is unknown. While this should not impact the seasonal variations observed in phytoplankton DLA rates, it does make these values more difficult to relate back to in situ DMS production.

\subsubsection{DMS yield measurements from ${ }^{35} \mathrm{~S}$ incubations}

As discussed in section 4.3.2.2.7, DMDS appears to inhibit DMS production in the potential enzyme assay. If confirmed, this would have significant consequences for the ${ }^{35}$ S-DMS yield assay, which is currently used as the primary mechanism for determining bacterial DMS production. Specifically, the addition of DMDS to the ${ }^{35} \mathrm{~S}$ DMS yield assay could be resulting in significant underestimates of bacterial DMS production. Further work is needed to determine the impact of DMDS on DMS

production. The first step would be to compare the rates of the standard ${ }^{35} \mathrm{~S}$-DMS yield 
assay to the rate without the addition of DMDS. This rate would need to be corrected for the consumption of DMS, which could be done using the ${ }^{35} \mathrm{~S}$ bacterial DMS consumption assay [Kiene and Linn, 2000b]. Additional tests could be conducted using the potential enzyme assay similar to those described in section 4.3.2.2.7. Once the issue of DMDS is

resolved, the ${ }^{35}$ S-DMS yield assay can be used to calibrate the bacterial DLA measurements. Specifically, if these two measurements show the same spatial and temporal distributions, the bacterial DLA measurements could be used for studies where the radioisotope techniques are not possible.

\subsection{CONCLUSION}

Based on numerous sensitivity experiments, we present the final methods for phytoplankton and bacterial DMSP lyase potential enzyme activity assays, DNA and RNA extraction from filters, and quantitative PCR analysis of BATS samples for the expression and abundance of DMSP degradation genes in environmental samples. The protocols for these methods, provided as Appendices $D-G$, are used during the 10 month time-series at BATS. These protocols include a new method that was developed to quantify bacterial DMSP lyase activity. The analysis of the BATS samples and discussion of the findings of this study are presented in Chapter 5. 


\subsection{REFERENCES}

Archer, S. D., C. E. Widdicombe, G. A. Tarran, A. P. Rees, and P. H. Burkill (2001), Production and turnover of particulate dimethylsulphoniopropionate during a coccolithophore bloom in the northern North Sea, Aquatic Microbial Ecology, 24(3), 225-241.

Bates, T. S., R. P. Kiene, G. V. Wolfe, P. A. Matrai, F. P. Chavez, K. R. Buck, B. W. Blomquist, and R. L. Cuhel (1994), The Cycling of Sulfur in Surface Seawater of the Northeast Pacific, Journal of Geophysical Research-Oceans, 99(C4), 7835-7843.

Buchan, A., J. M. Gonzalez, and M. A. Moran (2005), Overview of the marine Roseobacter lineage, Applied and Environmental Microbiology, 71(10), 5665-5677.

Cantoni, G. L., and D. G. Anderson (1956), Enzymatic cleavage of dimethylpropiothetin by polysiphonia lansoa, Journal of Biological Chemistry, 222, 171-177.

Carlson, C. A., H. W. Ducklow, and T. D. Sleeter (1996), Stocks and dynamics of bacterioplankton in the northwestern Sargasso Sea, Deep-Sea Research Part Ii-Topical Studies in Oceanography, 43(2-3), 491-515.

Chandler, D. P., C. A. Wagnon, and H. Bolton (1998), Reverse transcriptase (RT) inhibition of PCR at low concentrations of template and its implications for quantitative RT-PCR, Applied and Environmental Microbiology, 64(2), 669-677.

Christaki, U., S. Belviso, J. R. Dolan, and M. Corn (1996), Assessment of the role of copepods and ciliates in the release to solution of particulate DMSP, Marine EcologyProgress Series, 141(1-3), 119-127.

Curson, A. R. J., R. Rogers, J. D. Todd, C. A. Brearley, and A. W. B. Johnston (2008), Molecular genetic analysis of a dimethylsulfoniopropionate lyase that liberates the climate-changing gas dimethylsulfide in several marine alpha-proteobacteria and Rhodobacter sphaeroides, Environmental Microbiology, 10(3), 757-767.

del Valle, D. A., D. J. Kieber, and R. P. Kiene (2007), Depth-dependent fate of biologically-consumed dimethylsulfide in the Sargasso Sea, Marine Chemistry, 103(1-2), 197-208. 
Desouza, M. P., and D. C. Yoch (1995), Purification and Characterization of Dimethylsulfoniopropionate Lyase from an Alcaligenes-Like Dimethyl SulfideProducing Marine Isolate, Applied and Environmental Microbiology, 61(1), 21-26.

Gonzalez, J. M., R. P. Kiene, and M. A. Moran (1999), Transformation of sulfur compounds by an abundant lineage of marine bacteria in the alpha-subclass of the class Proteobacteria, Applied and Environmental Microbiology, 65(9), 3810-3819.

Gonzalez, J. M., et al. (2003), Silicibacter pomeroyi sp nov and Roseovarius nubinhibens sp nov., dimethylsulfoniopropionate-demethylating bacteria from marine environments, International Journal of Systematic and Evolutionary Microbiology, 53, 1261-1269.

Harada, H., M. A. Rouse, W. Sunda, and R. P. Kiene (2004), Latitudinal and vertical distributions of particle-associated dimethylsulfoniopropionate (DMSP) lyase activity in the western North Atlantic Ocean, Canadian Journal of Fisheries and Aquatic Sciences, 61(5), 700-711.

Hill, R. W., B. A. White, M. T. Cottrell, and J. W. H. Dacey (1998), Virus-mediated total release of dimethylsulfoniopropionate from marine phytoplankton: a potential climate process, Aquatic Microbial Ecology, 14(1), 1-6.

Howard, E. C., S. L. Sun, E. J. Biers, and M. A. Moran (2008), Abundant and diverse bacteria involved in DMSP degradation in marine surface waters, Environmental Microbiology, 10(9), 2397-2410.

Howard, E. C., et al. (2006), Bacterial taxa that limit sulfur flux from the ocean, Science, $314,649-652$.

Keller, M. D., W. K. Bellows, and R. R. L. Guillard (1989), Dimethylsulfide production in marine phytoplankton, in Biogenic sulfur in the environment, edited by E. S. Saltzman and W. J. Cooper William, pp. 167-182, ACS Symposium Series, American Chemical Society, Washington, D.C.

Kiene, R. P. (1990), Dimethyl Sulfide Production from Dimethylsulfoniopropionate in Coastal Seawater Samples and Bacterial Cultures, Applied and Environmental Microbiology, 56(11), 3292-3297.

Kiene, R. P. (1996), Production of methanethiol from dimethylsulfoniopropionate in marine surface waters, Marine Chemistry, 54(1-2), 69-83. 
Kiene, R. P., and B. F. Taylor (1988), Demethylation of Dimethylsulfoniopropionate and Production of Thiols in Anoxic Marine-Sediments, Applied and Environmental Microbiology, 54(9), 2208-2212.

Kiene, R. P., and S. K. Service (1991), Decomposition of Dissolved Dmsp and Dms in Estuarine Waters - Dependence on Temperature and Substrate Concentration, Marine Ecology-Progress Series, 76(1), 1-11.

Kiene, R. P., and L. J. Linn (2000a), Distribution and turnover of dissolved DMSP and its relationship with bacterial production and dimethylsulfide in the Gulf of Mexico, Limnology and Oceanography, 45(4), 849-861.

Kiene, R. P., and L. J. Linn (2000b), The fate of dissolved dimethylsulfoniopropionate (DMSP) in seawater: Tracer studies using S-35-DMSP, Geochimica Et Cosmochimica Acta, 64(16), 2797-2810.

Kiene, R. P., L. J. Linn, and J. A. Bruton (2000), New and important roles for DMSP in marine microbial communities, Journal of Sea Research, 43(3-4), 209-224.

Kiene, R. P., L. J. Linn, J. Gonzalez, M. A. Moran, and J. A. Bruton (1999), Dimethylsulfoniopropionate and methanethiol are important precursors of methionine and protein-sulfur in marine bacterioplankton, Applied and Environmental Microbiology, 65(10), 4549-4558.

Kreader, C. A. (1996), Relief of amplification inhibition in PCR with bovine serum albumin or T4 gene 32 protein, Applied and Environmental Microbiology, 62(3), 11021106.

Kwint, R. L. J., and K. J. M. Kramer (1996), Annual cycle of the production and fate of DMS and DMSP in a marine coastal system, Marine Ecology-Progress Series, 134(1-3), 217-224.

Malmstrom, R. R., R. P. Kiene, and D. L. Kirchman (2004a), Identification and enumeration of bacteria assimilating dimethylsulfoniopropionate (DMSP) in the North Atlantic and Gulf of Mexico, Limnology and Oceanography, 49(2), 597-606.

Malmstrom, R. R., R. P. Kiene, M. T. Cottrell, and D. L. Kirchman (2004b), Contribution of SAR11 bacteria to dissolved dimethylsulfoniopropionate and amino acid uptake in the North Atlantic ocean, Applied and Environmental Microbiology, 70(7), 4129-4135. 
Matrai, P. A., and M. D. Keller (1994), Total Organic Sulfur and Dimethylsulfoniopropionate in Marine-Phytoplankton - Intracellular Variations, Marine Biology, 119(1), 61-68.

Michaels, A. F., et al. (1994), Seasonal patterns of ocean biogeochemistry at the UnitedStates JGOFS Bermuda Atlantic Time-series Study site, Deep-Sea Research Part IOceanographic Research Papers, 41(7), 1013-1038.

Moran, M. A., J. M. Gonzalez, and R. P. Kiene (2003), Linking a bacterial taxon to sulfur cycling in the sea: Studies of the marine Roseobacter group, Geomicrobiology Journal, 20(4), 375-388.

Niki, T., M. Kunugi, and A. Otsuki (2000), DMSP-lyase activity in five marine phytoplankton species: its potential importance in DMS production, Marine Biology, 136(5), 759-764.

Niki, T., M. Kunugi, K. Kohata, and A. Otsuki (1997), Annual monitoring of DMSproducing bacteria in Tokyo Bay, Japan, in relation to DMSP, Marine Ecology-Progress Series, 156, 17-24.

Nishiguchi, M. K., and L. J. Goff (1995), Isolation, Purification, and Characterization of Dmsp Lyase (Dimethylpropiothetin-Dethiomethylase-(4.4.1.3)) from the Red Alga Polysiphonia-Paniculata, Journal of Phycology, 31(4), 567-574.

Pinhassi, J., R. Simo, J. M. Gonzalez, M. Vila, L. Alonso-Saez, R. P. Kiene, M. A. Moran, and C. Pedros-Alio (2005), Dimethylsulfoniopropionate turnover is linked to the composition and dynamics of the bacterioplankton assemblage during a microcosm phytoplankton bloom, Applied and Environmental Microbiology, 71(12), 7650-7660.

Simo, R. (2001), Production of atmospheric sulfur by oceanic plankton: biogeochemical, ecological and evolutionary links, Trends in Ecology \& Evolution, 16(6), 287-294.

Simo, R., S. D. Archer, C. Pedros-Alio, L. Gilpin, and C. E. Stelfox-Widdicombe (2002), Coupled dynamics of dimethylsulfoniopropionate and dimethylsulfide cycling and the microbial food web in surface waters of the North Atlantic, Limnology and Oceanography, 47(1), 53-61.

Slezak, D., R. P. Kiene, D. A. Toole, R. Simo, and D. J. Kieber (2007), Effects of solar radiation on the fate of dissolved DMSP and conversion to DMS in seawater, Aquatic Sciences, 69(3), 377-393. 
Smith, D. C., and F. Azam (1992), A simple, economical method for measuring bacterial protein synthesis rates in seawater using 3H-leucine, Mar. Microb. Food Webs, 6, 107114.

Stefels, J., and L. Dijkhuizen (1996), Characteristics of DMSP-lyase in Phaeocystis sp (Prymnesiophyceae), Marine Ecology-Progress Series, 131(1-3), 307-313.

Steinke, M., G. Malin, S. M. Turner, and P. S. Liss (2000), Determinations of dimethylsulphoniopropionate (DMSP) lyase activity using headspace analysis of dimethylsulphide (DMS), Journal of Sea Research, 43(3-4), 233-244.

Sunda, W., D. J. Kieber, R. P. Kiene, and S. Huntsman (2002), An antioxidant function for DMSP and DMS in marine algae, Nature, 418(6895), 317-320.

Taylor, B. F., and D. C. Gilchrist (1991), New Routes for Aerobic Biodegradation of Dimethylsulfoniopropionate, Applied and Environmental Microbiology, 57(12), 35813584.

Todd, J. D., A. R. J. Curson, C. L. Dupont, P. Nicholson, and A. W. B. Johnston (2009), The dddP gene, encoding a novel enzyme that converts dimethylsulfoniopropionate into dimethyl sulfide, is widespread in ocean metagenomes and marine bacteria and also occurs in some Ascomycete fungi, Environmental Microbiology, 11(6), 1376-1385.

Todd, J. D., R. Rogers, Y. G. Li, M. Wexler, P. L. Bond, L. Sun, A. R. J. Curson, G. Malin, M. Steinke, and A. W. B. Johnston (2007), Structural and regulatory genes required to make the gas dimethyl sulfide in bacteria, Science, 315(5812), 666-669.

Toole, D. A., and D. A. Siegel (2004), Light-driven cycling of dimethylsulfide (DMS) in the Sargasso Sea: Closing the loop, Geophysical Research Letters, 31(9).

Toole, D. A., D. J. Kieber, R. P. Kiene, D. A. Siegel, and N. B. Nelson (2003), Photolysis and the dimethylsulfide (DMS) summer paradox in the Sargasso Sea, Limnology and Oceanography, 48(3), 1088-1100.

Van Diggelen, J., J. Rozema, D. M. J. Dickson, and R. Broekman (1986), Beta-3 Dimethylsulfoniopropionate Proline and Quaternary Ammonium Compounds in Spartina-Anglica in Relation to Sodium Chloride Nitrogen and Sulfur, New Phytologist, 103(3), 573-586. 
vanderMaarel, M., W. Aukema, and T. A. Hansen (1996), Purification and characterization of a dimethylsulfoniopropionate cleaving enzyme from Desulfovibrio acrylicus, Fems Microbiology Letters, 143(2-3), 241-245.

Varaljay, V., E. C. Howard, S. Sun, and M. A. Moran (submitted), Deep sequencing of a DMSP-degradgin gene (dmdA) using PCR primer pairs designed from marine metagenomic data.

Vila, M., R. Simo, R. P. Kiene, J. Pinhassi, J. A. Gonzalez, M. A. Moran, and C. PedrosAlio (2004), Use of microautoradiography combined with fluorescence in situ hybridization to determine dimethylsulfoniopropionate incorporation by marine bacterioplankton taxa, Applied and Environmental Microbiology, 70(8), 4648-4657.

Visscher, P. T., and B. F. Taylor (1994), Demethylation of Dimethylsulfoniopropionate to 3-Mercaptopropionate by an Aerobic Marine Bacterium, Applied and Environmental Microbiology, 60(12), 4617-4619.

Visscher, P. T., M. R. Diaz, and B. F. Taylor (1992), Enumeration of Bacteria Which Cleave or Demethylate Dimethylsulfoniopropionate in the Caribbean Sea, Marine Ecology-Progress Series, 89(2-3), 293-296.

Wolfe, G. V., E. B. Sherr, and B. F. Sherr (1994), Release and Consumption of Dmsp from Emiliania-Huxleyi During Grazing by Oxyrrhis-Marina, Marine Ecology-Progress Series, 111(1-2), 111-119.

Wolfe, G. V., S. L. Strom, J. L. Holmes, T. Radzio, and M. B. Olson (2002), Dimethylsulfoniopropionate cleavage by marine phytoplankton in response to mechanical, chemical, or dark stress, Journal of Phycology, 38(5), 948-960.

Yoch, D. C. (2002), Dimethylsulfoniopropionate: Its sources, role in the marine food web, and biological degradation to dimethylsulfide, Applied and Environmental Microbiology, 68(12), 5804-5815.

Yoch, D. C., J. H. Ansede, and K. S. Rabinowitz (1997), Evidence for intracellular and extracellular dimethylsulfoniopropionate (DMSP) lyases and DMSP uptake sites in two species of marine bacteria (vol 63, pg 3183, 1997), Applied and Environmental Microbiology, 63(11), 4625-4625.

Zubkov, M. V., B. M. Fuchs, S. D. Archer, R. P. Kiene, R. Amann, and P. H. Burkill (2001), Linking the composition of bacterioplankton to rapid turnover of dissolved 
dimethylsulphoniopropionate in an algal bloom in the North Sea, Environmental Microbiology, 3(5), 304-311.

Zubkov, M. V., B. M. Fuchs, S. D. Archer, R. P. Kiene, R. Amann, and P. H. Burkill (2002), Rapid turnover of dissolved DMS and DMSP by defined bacterioplankton communities in the stratified euphotic zone of the North Sea, Deep-Sea Research Part IiTopical Studies in Oceanography, 49(15), 3017-3038. 
Table 4.1: Dates for BATS 2008 cruises.

\begin{tabular}{|l|c|c|}
\hline & Start Date & End Date \\
\hline February & 11 th & 15 th \\
\hline March & 12 th & 16 th \\
\hline April & 14 th & 17 th \\
\hline May & 28 th & June $1 \mathrm{st}$ \\
\hline June & $21 \mathrm{st}$ & 24 th \\
\hline July & 15 th & $21 \mathrm{st}$ \\
\hline August & 11 th & 17 th \\
\hline September & 9 th & 14 th \\
\hline October & 6 th & 11 th \\
\hline November & 8 th & 16 th \\
\hline
\end{tabular}


Table 4.2: Monthly averages of volume of seawater filtered for RNA and DNA samples.

\begin{tabular}{|l|c|c|}
\hline \multirow{2}{*}{} & \multicolumn{2}{|c|}{ Average Volume Filtered (L) } \\
\cline { 2 - 3 } & RNA & DNA \\
\hline February & $2.62 \pm 0.48$ & $3.86 \pm 0.19$ \\
\hline March & $2.83 \pm 0.27$ & $3.98 \pm 0.05$ \\
\hline April & $2.79 \pm 0.19$ & $3.83 \pm 0.17$ \\
\hline May & $2.44 \pm 0.37$ & $3.07 \pm 0.31$ \\
\hline June & $2.49 \pm 0.24$ & $3.56 \pm 0.35$ \\
\hline July & $2.44 \pm 0.26$ & $3.58 \pm 0.36$ \\
\hline August & $2.35 \pm 0.24$ & $3.56 \pm 0.27$ \\
\hline September & $2.66 \pm 0.22$ & $3.66 \pm 0.24$ \\
\hline October & $2.45 \pm 0.24$ & $3.23 \pm 0.39$ \\
\hline November & $2.31 \pm 0.31$ & $3.91 \pm 0.17$ \\
\hline AVERAGE & $\mathbf{2 . 5 4}$ & $\mathbf{3 . 6 2}$ \\
\hline
\end{tabular}


Table 4.3: Monthly statistics for the bacterial (upper table) and phytoplankton (lower table) DMSP lyase potential enzyme activity (DLA) assay. The average error as a percent of the DLA rate, the average $\mathrm{R}^{2}$ value for the linear fit used to calculate the DLA rate, and the average assay temperature are given in columns, 1-3 respectively.

\section{Bacterial DLA assay}

\begin{tabular}{|l|c|c|c|}
\hline & $\begin{array}{l}\text { average error (\% } \\
\text { of rate) }\end{array}$ & $\begin{array}{c}\text { average } \mathbf{R}^{\mathbf{2}} \text { for } \\
\text { rate slone }\end{array}$ & $\begin{array}{c}\text { assay temp } \\
\left({ }^{\circ} \mathbf{C}\right)\end{array}$ \\
\hline Feb* $^{*}$ & $53.9 \%$ & 0.9271 & 21 \\
\hline March** $^{*}$ & $137.0 \%$ & 0.9458 & 21 \\
\hline April & $13.2 \%$ & 0.9728 & 22 \\
\hline May & $6.16 \% \dagger$ & 0.9762 & 22 \\
\hline June & $9.5 \%$ & 0.9865 & 24.5 \\
\hline July & $10 \% \dagger \dagger$ & 0.9921 & 25 \\
\hline Aug & $8.3 \%$ & 0.9901 & 26 \\
\hline Sept & $6.4 \%$ & 0.9944 & 26.5 \\
\hline Oct & $11.0 \%$ & 0.9947 & 25 \\
\hline Nov & $6.0 \%$ & 0.9938 & 23 \\
\hline AVERAGE*** & $\mathbf{9 . 1 \%}$ & $\mathbf{0 . 9 8 7 6}$ & $\mathbf{2 3 . 6}$ \\
\hline
\end{tabular}

- Average error excluding $100 \mathrm{~m}$ samples ( DLA very close to zero at $100 \mathrm{~m}$ )

* These samples were run on a GC with Sulfur Chemiluminescence Detection due to problems with the GC-PFPD

** These samples were run using the direct inject method on the GC-PFPD instead of the trapping method

*** Average values April through November. Samples run on the GC-PFPD using the trapping method

$\dagger$ Error without $0 \mathrm{~m}$ and $10 \mathrm{~m}$ samples (DLA very close to zero). Error with these depths is $848 \%$

$\dagger \dagger$ Error without $0 \mathrm{~m}$ sample (DLA very close to zero). Error with $0 \mathrm{~m}$ is $35.3 \%$

Phytoplankton DLA assay

\begin{tabular}{|l|c|c|c|}
\hline & $\begin{array}{l}\text { average error (\% } \\
\text { of rate) }\end{array}$ & $\begin{array}{c}\text { average } \mathbf{R}^{\mathbf{2}} \text { for } \\
\text { rate slone }\end{array}$ & $\begin{array}{c}\text { assay temp } \\
\left({ }^{\circ} \mathbf{C}\right)\end{array}$ \\
\hline Feb* $^{*}$ & $7.6 \%$ & 0.9845 & 21 \\
\hline March $^{* *}$ & $10.7 \%$ & 0.9869 & 21 \\
\hline April & $6.3 \%$ & 0.9852 & 22 \\
\hline May & $11.1 \%$ & 0.9844 & 22 \\
\hline June & $14.9 \%$ & 0.9857 & 24.5 \\
\hline July & $4.5 \%$ & 0.9881 & 25 \\
\hline Aug & $13.2 \%$ & 0.9854 & 26 \\
\hline Sept & $4.7 \%$ & 0.9817 & 26.5 \\
\hline Oct & $9.2 \%$ & 0.9889 & 25 \\
\hline Nov & $8.0 \%$ & 0.9808 & 23 \\
\hline AVERAGE*** & $\mathbf{9 . 0 \%}$ & $\mathbf{0 . 9 8 5 0}$ & $\mathbf{2 3 . 6}$ \\
\hline
\end{tabular}

- Average error excluding $100 \mathrm{~m}$ samples ( DLA very close to zero at $100 \mathrm{~m}$ )

* These samples were run on a GC with Sulfur Chemiluminescence Detection due to problems with the GC-PFPD

** These samples were run using the direct inject method on the GC-PFPD instead of the trapping method

*** Average values April through November. Samples run on the GC-PFPD using the trapping method 
Table 4.4: Impact of polycarbonate filters on observed DMS concentrations. The abiotic rate of DMSP degradation measured in October with and without a polycarbonate filter is given in row 1 . The standard curves were measured on for four different days during the November cruise with and without a polycarbonate filter. The slopes of these standard curves are presented in rows 2-5. The filter correction is the ratio of the observed slope with a polycarbonate filter to the slope without a filter.

\begin{tabular}{|l|c|c|c|}
\hline \multirow{2}{*}{} & \multicolumn{2}{|c|}{ Slope* } & \multirow{2}{*}{$\begin{array}{c}\text { Filter } \\
\text { Correction }\end{array}$} \\
\cline { 2 - 3 } & without filter & with filter & 0.55 \\
\hline October control & 0.08 & 0.04 & 0.67 \\
\hline November standards & 62.89 & 41.87 & 0.65 \\
\hline November standards & 65.70 & 42.52 & 0.54 \\
\hline November standards & 68.52 & 36.72 & 0.50 \\
\hline November standards & 146.29 & 73.29 & \\
\hline
\end{tabular}

$\begin{array}{ll}\text { Average Correction } & \mathbf{0 . 5 8} \\ \text { Standard Deviation } & \mathbf{0 . 0 7}\end{array}$

* Units for October control are nmol/min, units for November standards are peak area/ $\mu \mathrm{M}$ 


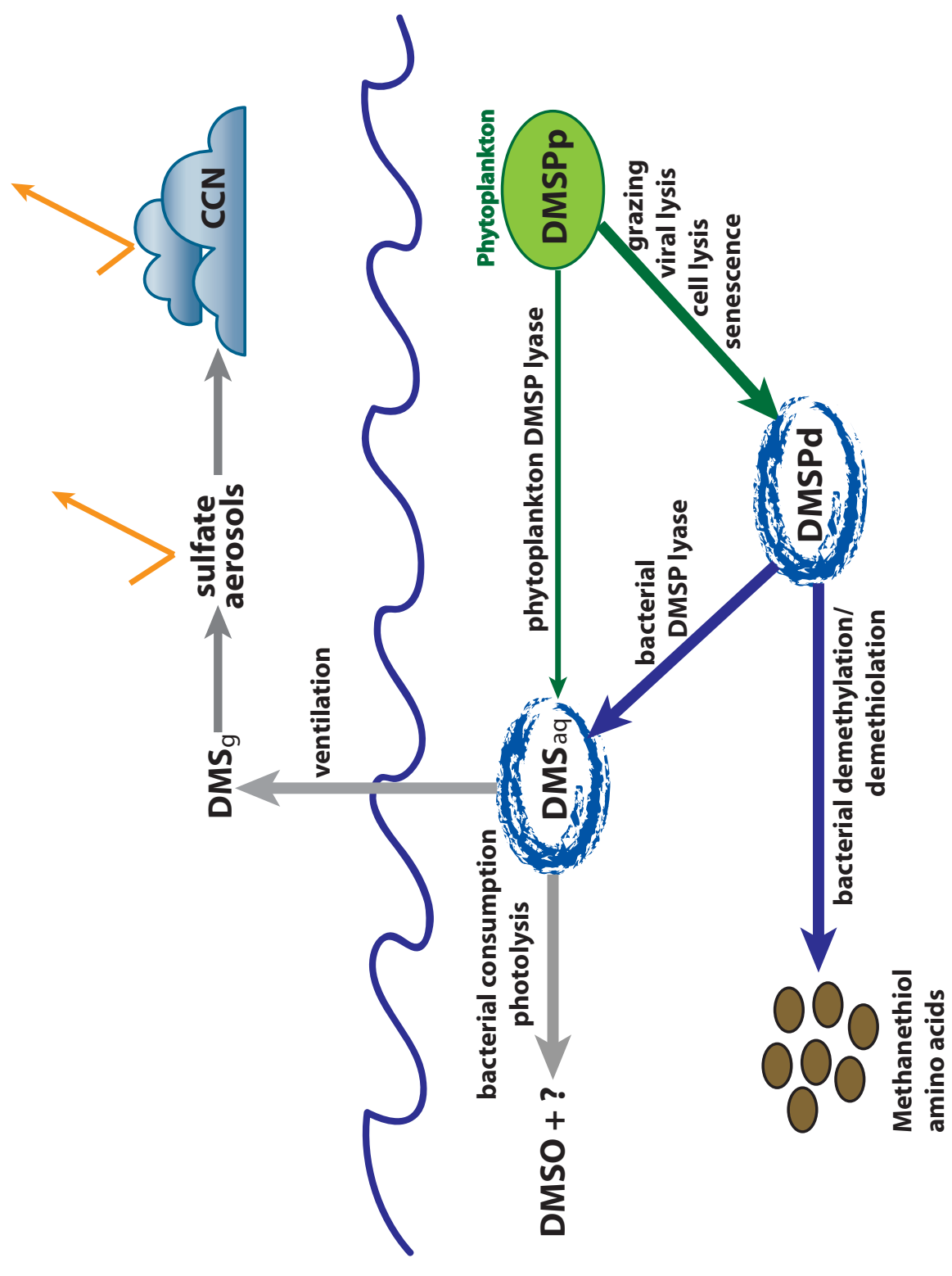

六 $\frac{n}{2} \cdot \frac{n}{0} \cdot \frac{0}{0}$

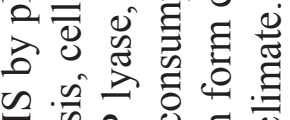

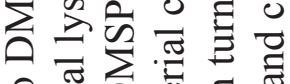

ㅇ. 플

రृ

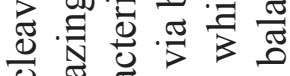

施

으의

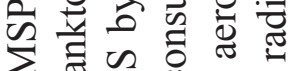
$\sum$ 제 00 क

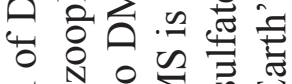

กี

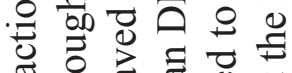

ॠ

《栲

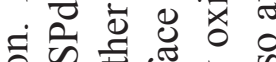

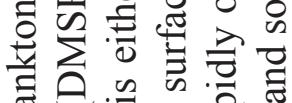

즐 -

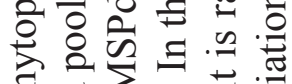

결 券

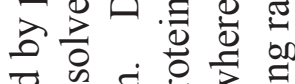

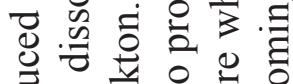

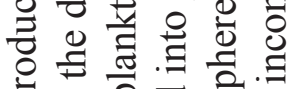

है 0 त्र क

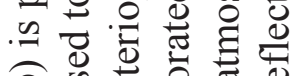

2ิ

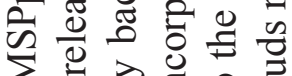

元司. 응

규 귱

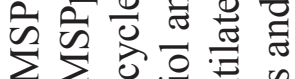

施之语苛

능휴

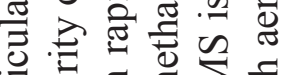

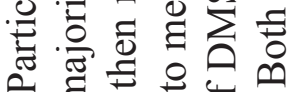

น छ

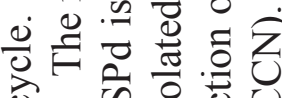

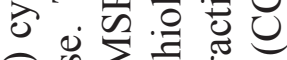

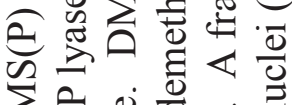

$\sum_{1}^{\infty} \dot{0} \overline{0} \dot{0}$

‥

$\because 0$ 엥

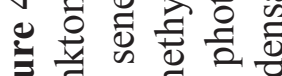

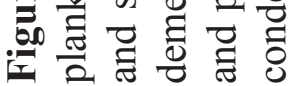




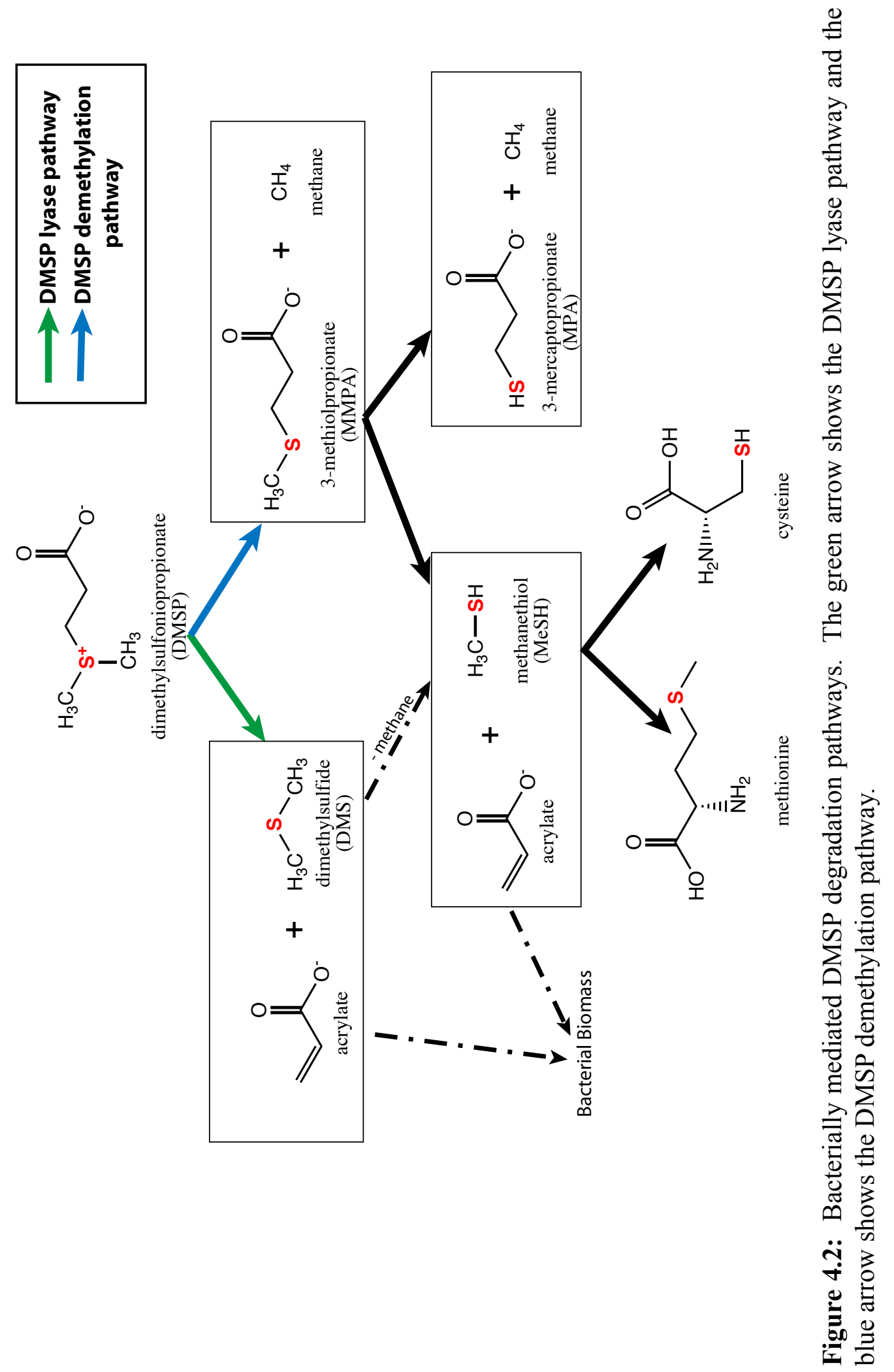


a)

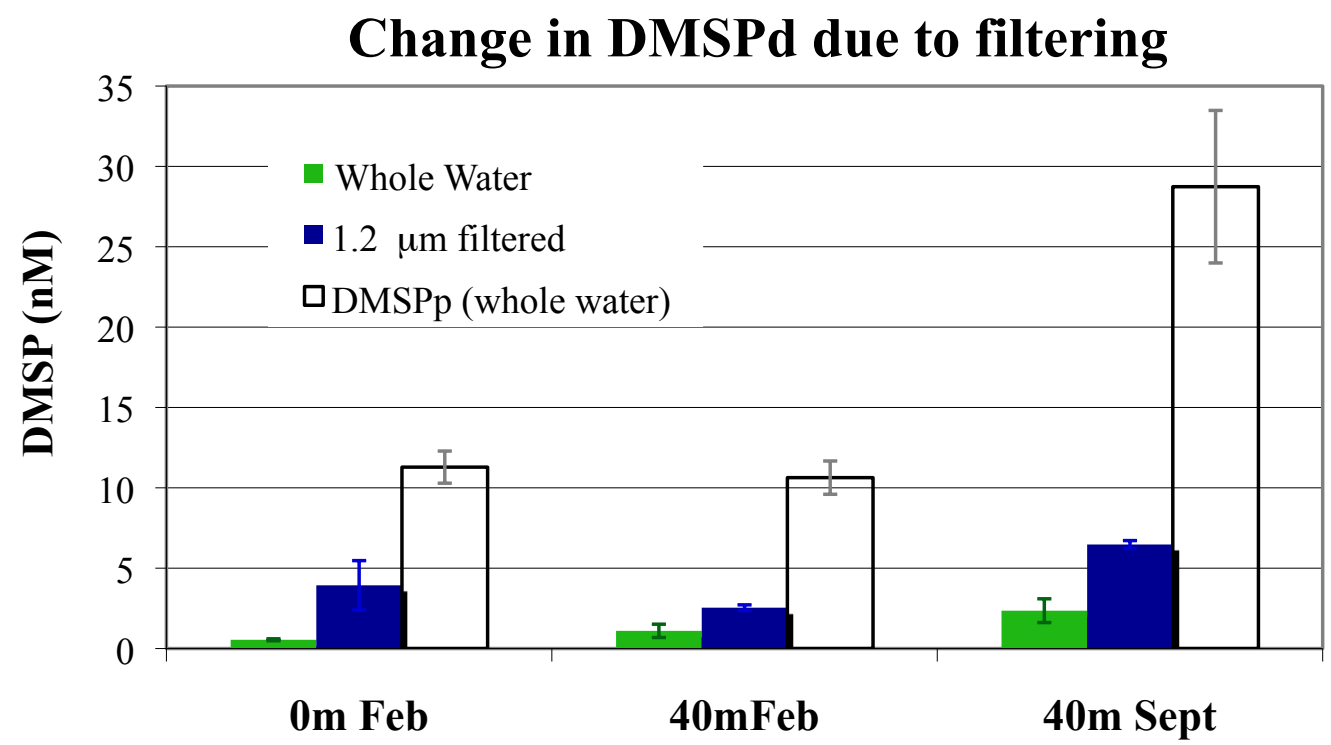

b)

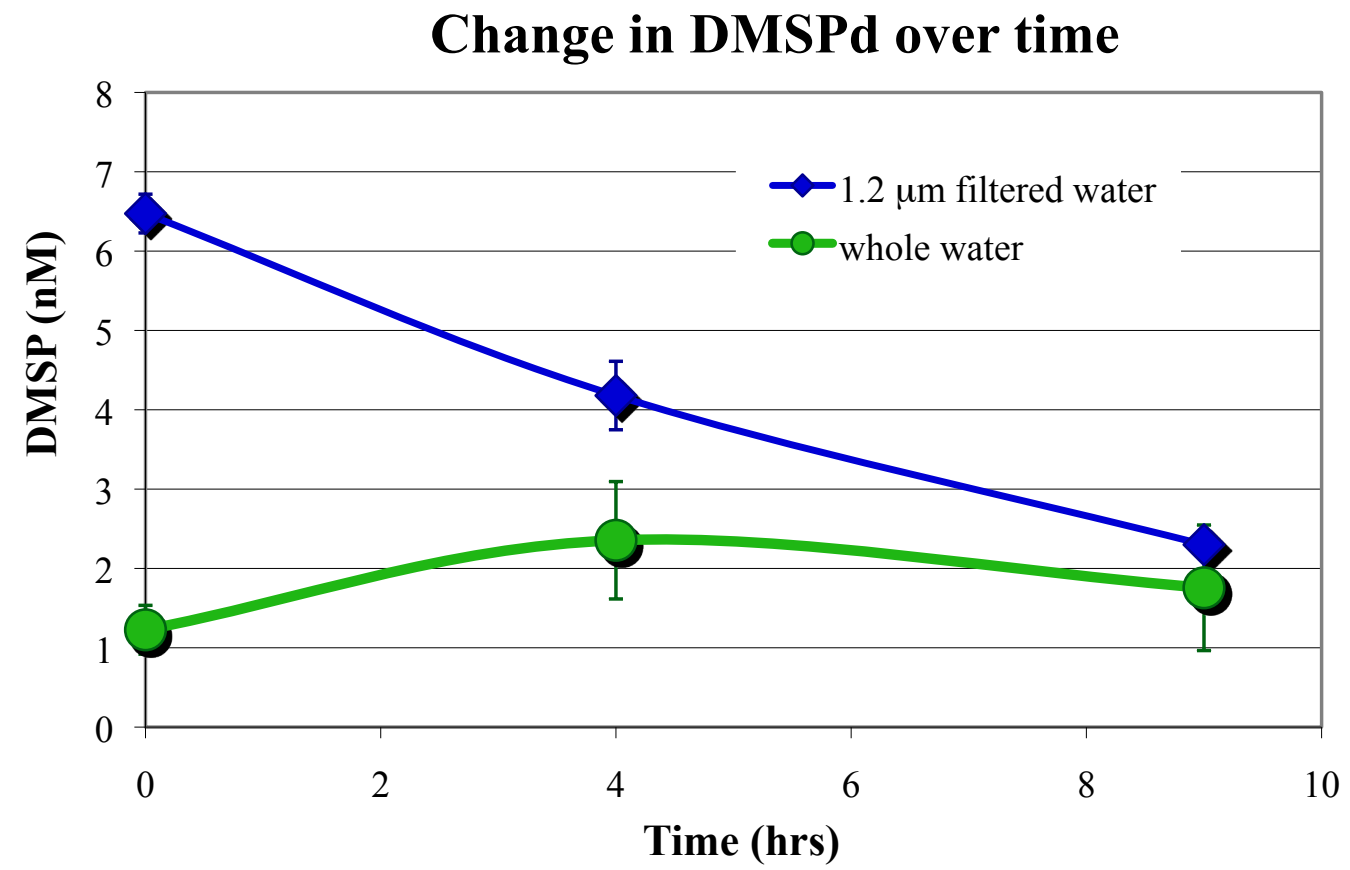

Figure 4.3: Change in DMSPd in DLA assays. Panel a) shows the ambient DMSPd and DMSPp concentrations for whole water and the increase in DMSPd concentration as a result of pre-filtering with $1.2 \mu \mathrm{m}$ in-line filters. Panel b) shows the change in DMSPd concentrations over a $9 \mathrm{~h}$ period in samples collected for bacterial $(1.2 \mu \mathrm{m}$ filtered water) and phytoplankton (whole water) DLA assays. No significant change was seen in the phytoplankton samples over time. Significant consumption of DMSPd was observed in the bacterial samples over $9 \mathrm{~h}$, however the final concentrations was greater than zero. 
a)

\section{Control Temperature Dependence}

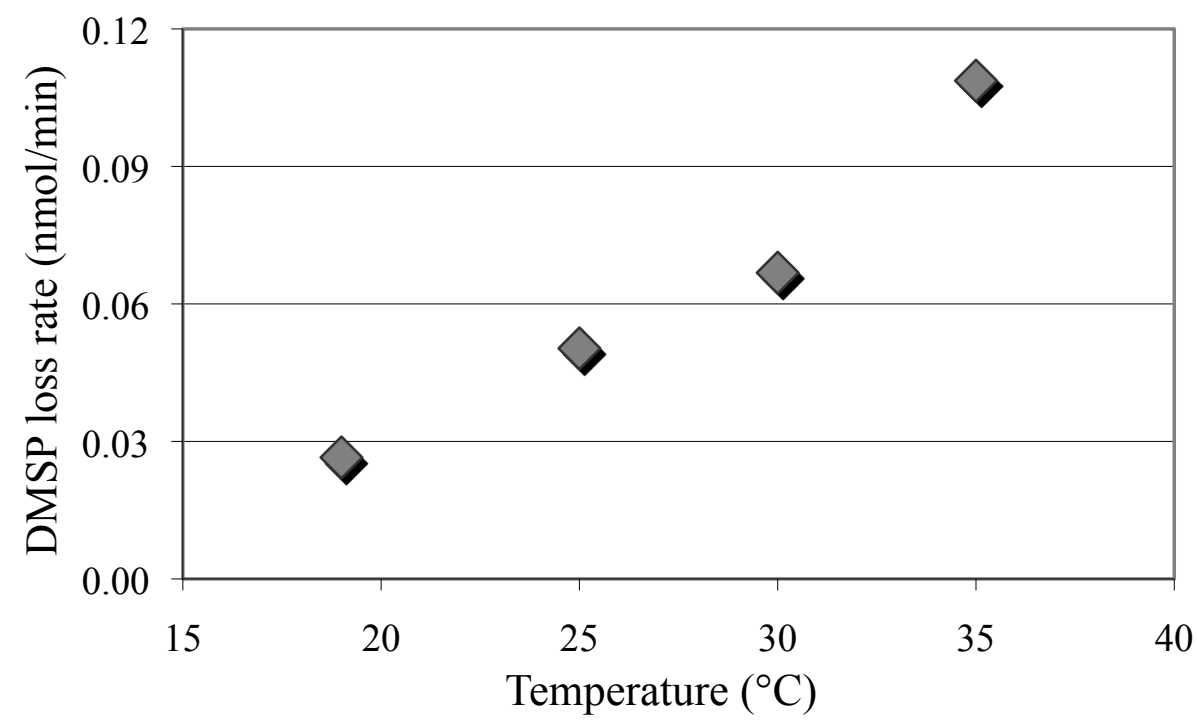

b)

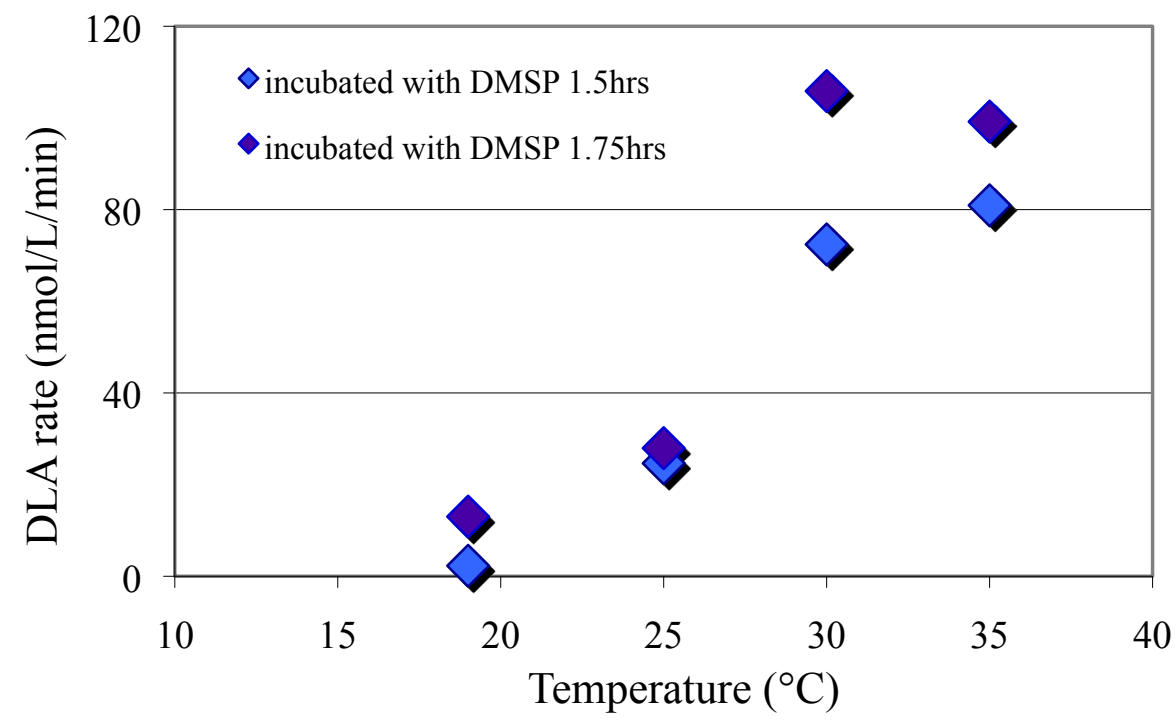

Figure 4.4: Temperature dependence of bacterial DLA and abiotic DMSP degradation. Panel a) shows the abiotic degradation of DMSP for four different temperatures $\left(19^{\circ}, 15^{\circ}\right.$, $30^{\circ}$, and $35^{\circ} \mathrm{C}$ ). The DMSP degradation rates are presented in nmol/min (nmol of DMS produced or DMSP degraded per minute). Panel b) shows bacterial DLA for the four different temperatures measured for Ruegeria pomeroyi. Two sets of samples were run, one incubated with DMSP for 1.5 hours and one incubated with DMSP for 1.75. The DLA rates are presented in $\mathrm{nmol} / \mathrm{L} / \mathrm{min}$ (nmol of DMS produced per minute per L of sample). DLA rates are normalized by volume of sample filtered, in this case $7 \mathrm{ml}$. For this test, the abiotic DMSP degradation was on average $20 \%$ of the DLA rate. 


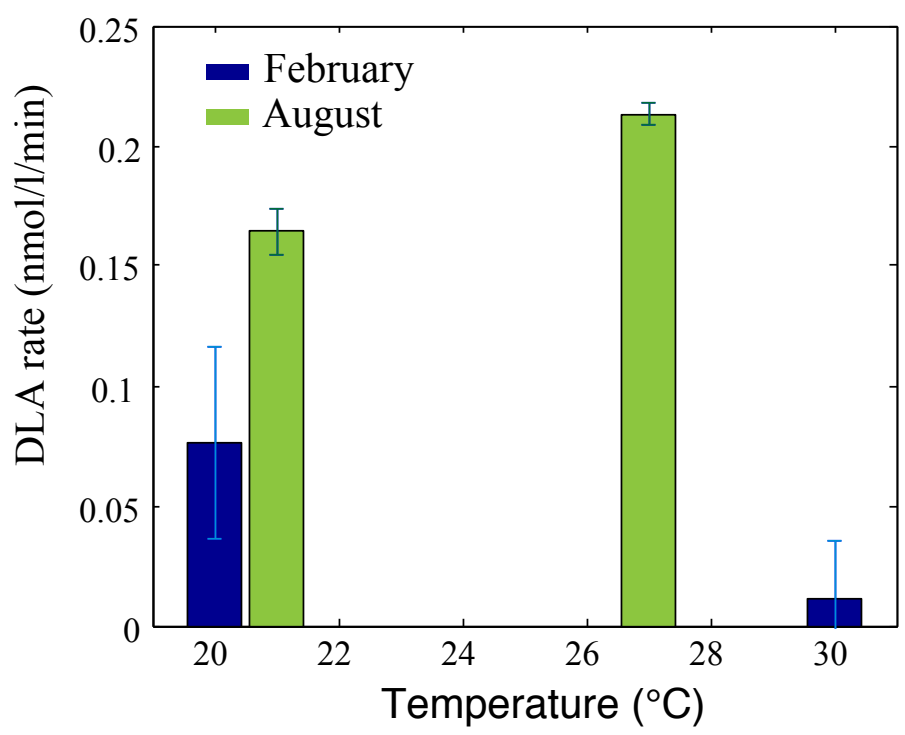

Figure 4.5: Temperature dependence of bacterial DLA in the field. The bacterial DLA of identical samples from $40 \mathrm{~m}$ were measured at two different temperatures in February and August. February samples were measured at $20^{\circ} \mathrm{C}$ and $30^{\circ} \mathrm{C}$ and August samples were measured at $21^{\circ} \mathrm{C}$ and $27^{\circ} \mathrm{C}$. 
a)

Change in Bacterial DLA (40m)

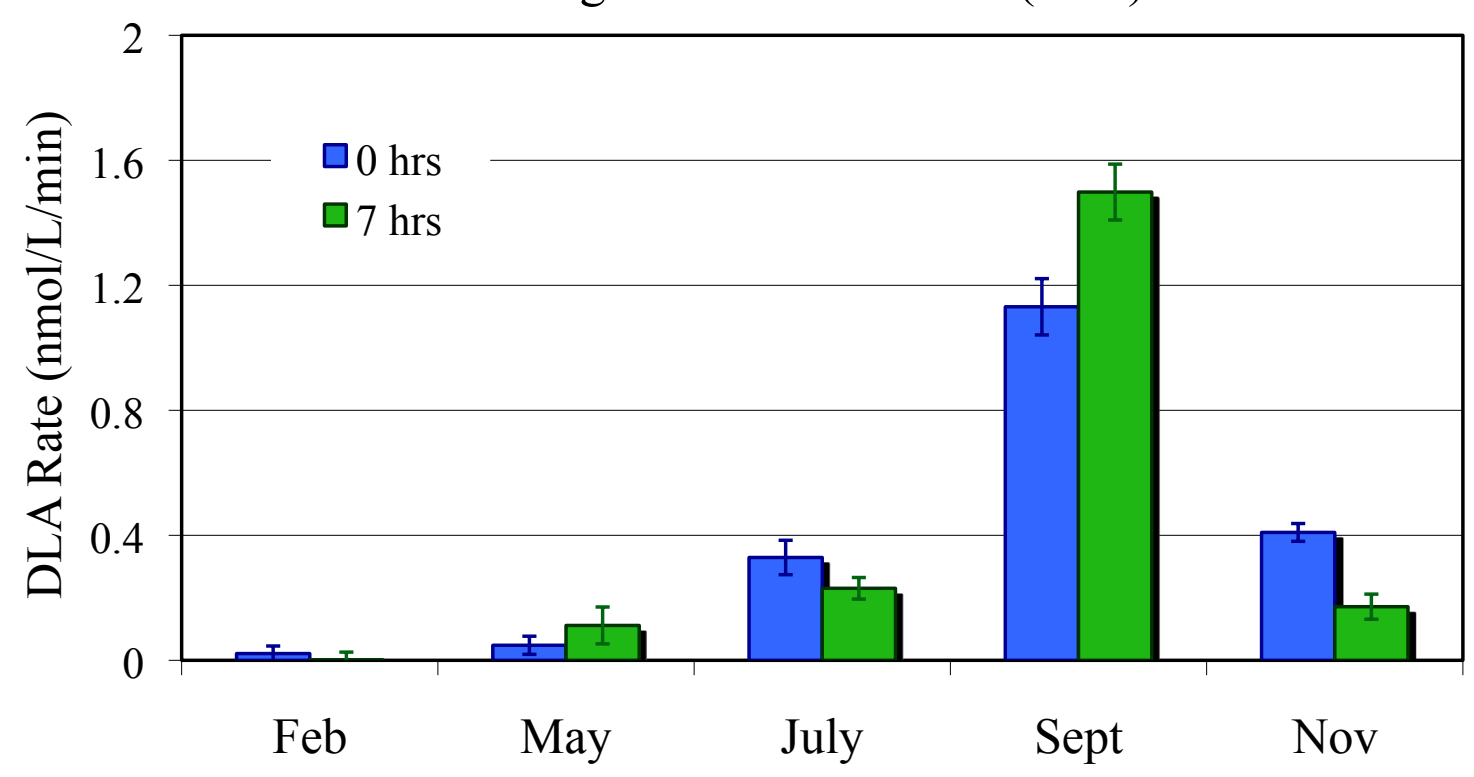

b)

Change in Phytoplankton DLA (40m)

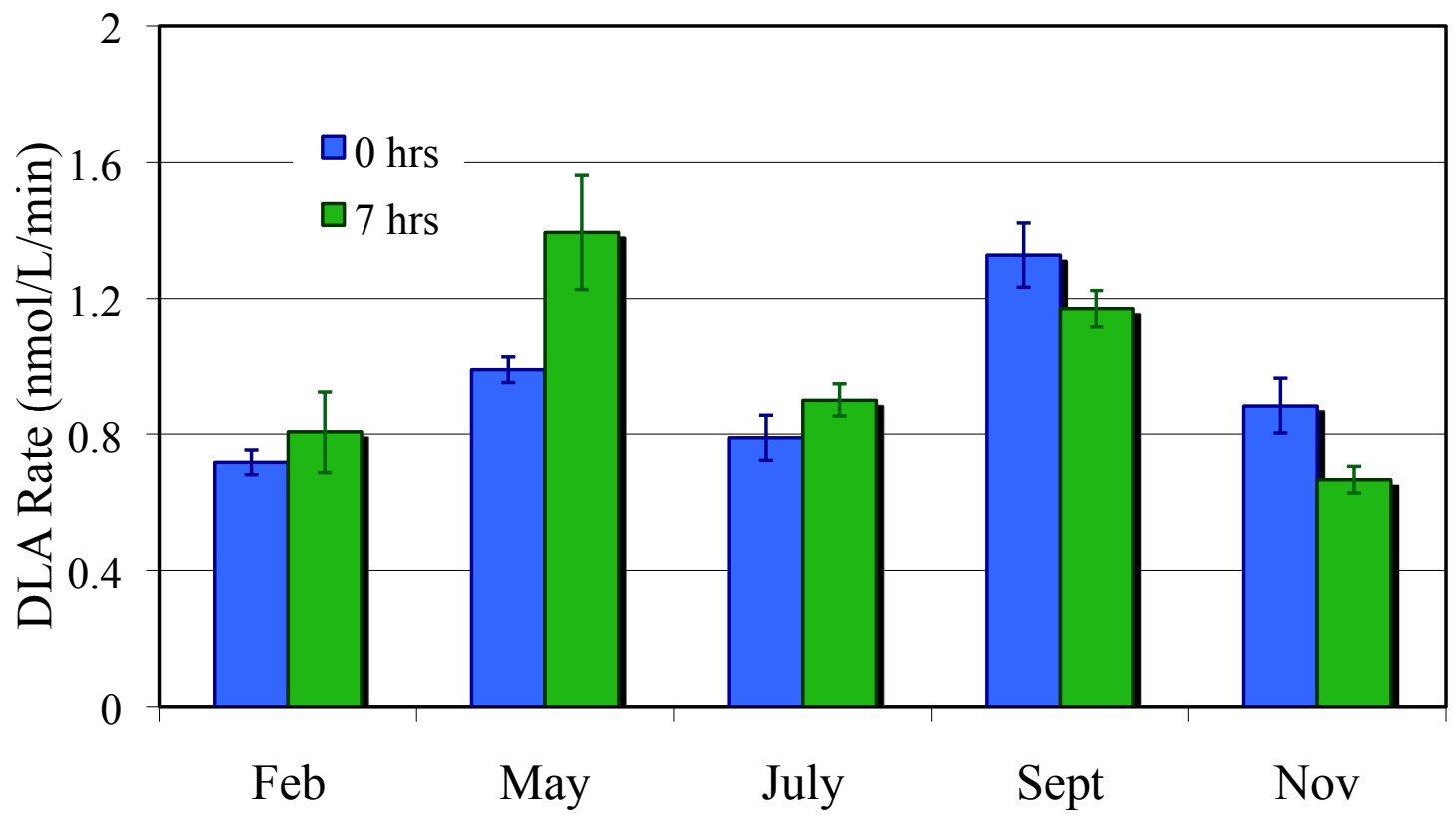

Figure 4.6: The impact of 'on-deck waiting time' on DLA rates. The change in 40m bacterial DLA (panel a) and $40 \mathrm{~m}$ phytoplankton DLA (panel b) over $7 \mathrm{~h}$ was quantified in February, May, July, September, and November. The DLA rates are presented in $\mathrm{nmol} / \mathrm{L} / \mathrm{min}$. 


\section{RNA extraction hood}

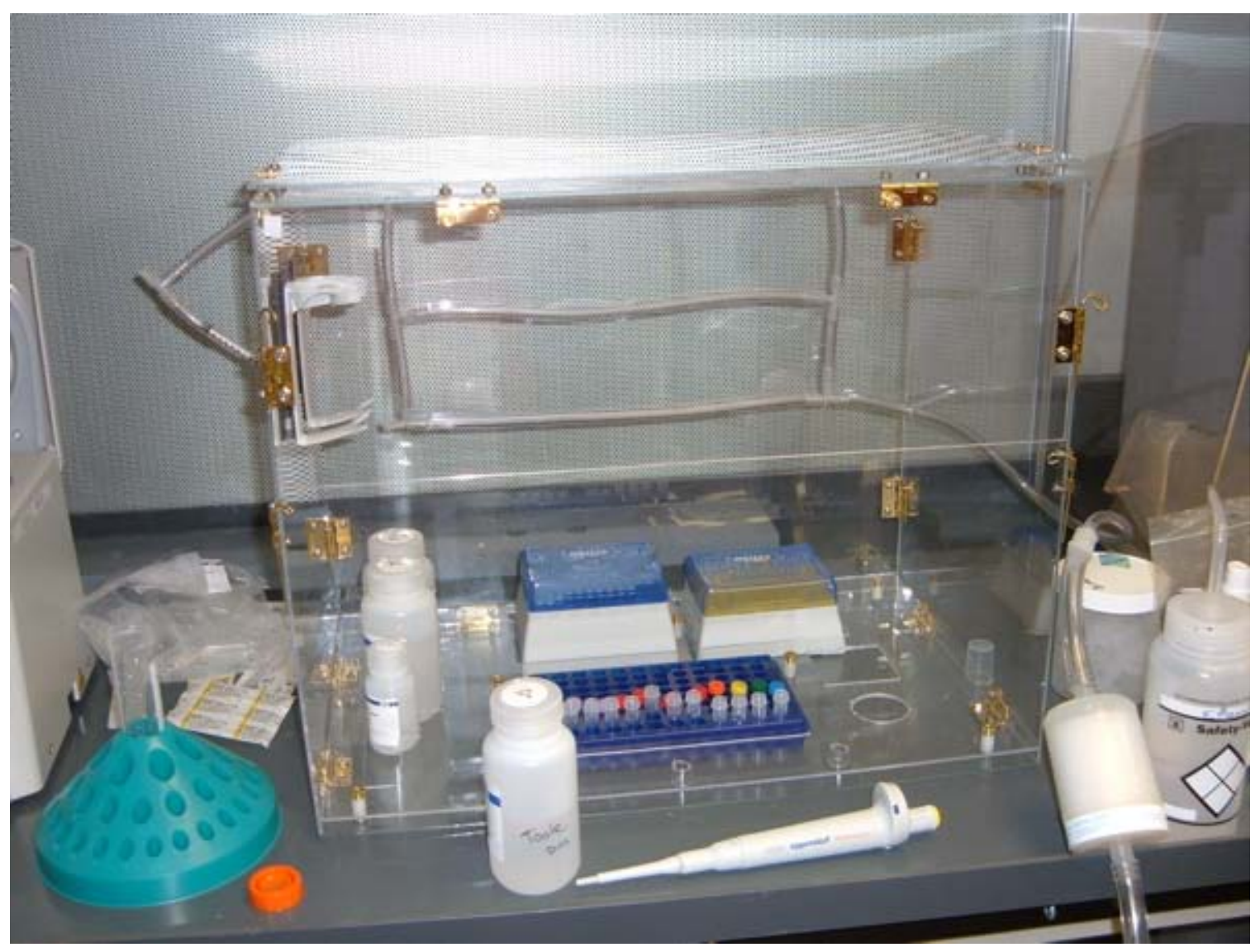

Figure 4.7: Plexiglas RNA extraction hood with quasi-laminar flow HEPA filtered air built by N. Levine and D. Levine. 


\section{Chapter 5:}

\section{The Upper Ocean Sulfur Cycle: Understanding the key bacterial and phytoplankton functional groups involved in DMSP degradation}

\subsection{INTRODUCTION: The Summer Paradox and the Seasonal}

Sulfur Cycle at the Bermuda Atlantic Time-series Study site

The seasonal variations in DMS and DMSP concentrations and biogeochemical transformation rates are primarily mediated by the upper ocean food web (see Chapter 4 section 4.1 for our current understanding of the upper ocean sulfur cycle). However, the 
relative importance of and variability in the dominant microbe groups responsible for DMSP cycling in the upper ocean sulfur cycle also has yet to be elucidated. In particular, the importance and relative magnitude of bacterial DMS production and seasonal variability in the fate of dissolved DMSP (DMSPd) consumed by bacteria (demethylation versus cleavage) has yet to be determined. Here we investigate the role of the microbial and phytoplankton communities in DMS(P) transformations.

Genomic studies suggest that both $\alpha$ - and $\gamma$ - proteobacteria have DMSP degradation genes. In addition, field work has shown that two $\alpha$-proteobacteria groups, SAR11 and roseobacters, are the dominant DMSPd consumers in open ocean systems [Malmstrom et al., 2004a; Malmstrom et al., 2004b]. Bacteria degrade DMSP via two pathways, the DMSP demethylation pathway, which excludes DMS as a product, and the DMSP cleavage pathway, which produces DMS. We quantify these two pathways using the expression and abundance of $d m d A$, which is involved in the demethylation of DMSP, and $d d d P$, a DMSP cleavage gene. In addition, we estimate bacterial and phytoplankton DMS production using potential enzyme assays (described in Chapter 4 section 4.3.2). These biological measurements combined with the suite of chemical and physical measurements described in Chapter 4 provide insight into the driving chemical and physical mechanisms behind seasonal variability in oligotrophic upper ocean DMS and DMSP (DMS(P)) concentrations and the dominant microbe groups mediating these transformations.

In oligotrophic regions, a temporal and spatial disconnect has been identified between concentrations of dimethylsulfide (DMS) and its precursor 
dimethylsulfoniopropionate (DMSP) [Simo and Pedros-Alio, 1999]. It is hypothesized that this 'summer paradox' in upper ocean sulfur distributions is caused by ultraviolet (UV) radiation stress that increases phytoplankton DMS production and decreases bacterial DMS consumption [Slezak et al., 2007; Toole et al., 2008; Toole et al., 2003; Vallina and Simo, 2007; Vila-Costa et al., 2007]. The driving mechanisms behind the 'summer paradox' have been explored using manipulation experiments in the laboratory and field and with numerical models but have yet to be demonstrated in in-situ environmental samples.

The 'summer paradox' is observed in the three year Bermuda Atlantic Timeseries Study site (BATS) organic sulfur time-series leveraged by this study [Toole et al., in prep, Figure 5.1]. The seasonal variability in sulfur distributions observed for 2008 (Figure 5.1) were not always representative of the trends observed during the longer time-series and discussed in Toole et al. [in prep]. This is due to a series of events that are superimposed on top of the seasonal cycle (discussed below). Particulate DMSP (DMSPp) concentrations peak in the spring (March -April) concurrent with the shoaling of the mixed layer and remain high throughout the summer (Figure 5.1b). DMSPp concentrations then decrease in the fall when mixed layers begin to deepen and remain low until the spring bloom. DMS concentrations peak in the summer (May-June), several months after DMSPp concentrations increase, and remain elevated until the fall mixing events (Figure 5.1a). In addition to the temporal disconnect between DMS and DMSPp concentrations, a depth disconnect is also observed. DMSPp concentrations are highest between $40 \mathrm{~m}$ and $60 \mathrm{~m}$ whereas peak DMS concentrations are always observed just below 
the summer mixed layer at approximately $20 \mathrm{~m}$. The low concentrations of DMS observed within the mixed layer may be explained by loss of DMS through ventilation to the atmosphere, photolysis, or bacterial consumption. DMSPd, the pool cycled by the microbial community, does not show a clear seasonal cycle at BATS (Figure 5.1c). However, DMSPd and DMSPp concentrations are positively related (Figure 5.2), indicating that the release of DMSPp into the water column through phytoplankton cell senescence and other processes is important in determining DMSPd concentrations.

Previous authors have suggested that the spatial offset between peak DMSPp concentrations and DMS concentrations is due to a phytoplankton anti-oxidant response [e.g. Sunda et al., 2002; Toole et al., 2003]. DMSP and its degradation products, DMS and acrylate, have been shown to scavenge free hydroxy radicals and other reactive oxygen species suggesting that cells use these compounds to protect against oxidative stress. UV radiation is highest in the upper water column and attenuates with depth to a $1 \%$ light level at $40 \mathrm{~m}$ for $324 \mathrm{~nm}$ and $\sim 90 \mathrm{~m}$ for $412 \mathrm{~nm}$, during the summertime in the Sargasso Sea [Toole et al., 2003]. UV dose is related both to UV irradiance and to the mixed layer depth (MLD). MLD is defined as the minimum depth where the potential density $\left(\sigma_{\theta}\right)$ is greater than the potential density calculated using surface water salinity and surface temperature minus $0.2^{\circ} \mathrm{C}$ [Sprintall and Tomczak, 1992]. The mean monthly MLD is calculated as the average value of the cast MLDs made during the monthly cruise $(\mathrm{N}=15-27)$. $1 \sigma$ error is calculated as the standard deviation of the cast MLDs. Deep mixed layers, such as those found in the winter, act to decrease the UV dose experienced 
by the surface planktonic community by reducing the time that these organisms are exposed to high-UV radiation.

The growth of surface ocean microbial communities in oligotrophic regions is limited by the availability of bioavailable dissolved organic carbon (DOC) [Carlson et al., 2002]. DOC is defined as:

$D O C=T O C-P O C$

where TOC is total organic carbon and POC is particulate organic carbon. Monthly TOC and POC are quantified by the BATS team [http://bats.bios.edu/, Knap et al., 1997; Steinberg et al., 2001]. Unfortunately, due to large gaps in the POC dataset, we are unable to calculate DOC values for a significant portion of this time-series. However, spatial and temporal variability of the TOC pool is driven by changes in DOC that accounts for 96-99\% of TOC at BATS [Carlson et al., 1998; Hansell and Carlson, 1998]. Therefore, we use TOC as a proxy for DOC. We assume that the bioavailable fraction of TOC can be equated with semi-labile Total Organic Carbon (semi-labile TOC) [Carlson et al., 1994], plotted in Figure 5.1d, where semi-labile TOC is calculated as:

$T O C_{\text {semi-labile }}=T O C-T O C_{>3000 \mathrm{~m}}$

where $\mathrm{TOC}_{>3000 \mathrm{~m}}$ is the mean TOC concentration measured at depths greater than $3000 \mathrm{~m}$ during February-November 2008.

Several events impacted the BATS site during the spring and summer of 2008. These events resulted in changes to the upper ocean sulfur cycle that are superimposed on top of the typical seasonal cycle. First, the site was under the influence of a cyclonic eddy in May [D. McGillicuddy per. comm.]. Cyclonic eddies upwell nutrient rich 
thermocline water typically increasing biologic activity [McGillicuddy et al., 2003; McGillicuddy et al., 1998]. In May of 2008, shoaling of the isotherms at BATS was observed in addition to slightly elevated chlorophyll a concentrations in the upper $100 \mathrm{~m}$, relative to spring and summertime values for 2008 (data not shown), and elevated bacterial cell counts particularly at 60m. High DMSPp and DMSPd concentrations were measured in May along with the highest DMSPd consumption rates observed in 2008. We hypothesize that this increase in DMSPp concentrations, and corresponding increase in rates of $\mathrm{DMS}(\mathrm{P})$ cycling, may be due to a 'bloom' of DMSP producers resulting from the increased nutrient supply in the cyclonic eddy and the subsequent bloom of DMSP consumers. Supporting evidence for this hypothesis is found in the genomic profile for May that shows increased abundance of several groups of DMSP degraders (discussed below). However, it is difficult to definitively separate this signal from the seasonal shoaling of the mixed layer, which occurs between March and April at BATS, and results in increased DMSPp and DMS concentrations. The steep rate of change in DMSPp concentrations during this time period and significant interannual variability makes it difficult to determine if May of 2008 was significantly different from the preceding two years.

Secondly, the BATS site was heavily influenced by Hurricane Bertha during July of 2008. Bertha passed directly over BATS with tropical storm force winds $(>63 \mathrm{~km} / \mathrm{hr})$ impacting BATS for 4 days immediately preceding the July cruise [National Hurricane Center, NOAA http://www.nhc.noaa.gov/archive/2008/graphics/al02/loop_R.shtml]. Due to rapid restratification of the surface waters, the mixed layer depth calculated from 
potential density for July is $14.8 \mathrm{~m} \pm 6 \mathrm{~m}$, a typical summertime value. However, the remnant of the deep mixed layer imparted by Hurricane Bertha, as evident by disturbances in the isotherms at depth, was still present during the July occupation. The depth of the remnant mixed layer is $41.4 \mathrm{~m} \pm 14 \mathrm{~m}$ (dashed gray line in Figure 5.1). As shown in Figure 5.1, DMS, DMSPp and DMSPd concentrations in July are significantly decreased as compared to June and August, with July values of these properties similar to those observed in April (MLD of 33.9m $\pm 16 \mathrm{~m}$ ). We hypothesize that increased vertical mixing created by the hurricane winds decreased the UV radiation stress experienced by surface phytoplankton resulting in lower DMSPp and therefore lower DMSPd concentrations. Similarly, the decrease in UV radiation stress may have relieved some inhibition of DMS consumption in surface waters thereby increasing rates in July particularly at 20m (Figure 5.1f) [Slezak et al., 2001; Toole et al., 2006]. The combination of increased DMS consumption combined with increased ventilation to the atmosphere explains the low DMS concentrations in the surface waters in July. DMSPd consumption also decreased in July to values similar to those observed in April. Labile TOC concentrations increased at 40 and $50 \mathrm{~m}$ in July possibly due to mixing with high TOC surface waters during the hurricane.

Finally, during January 2008, immediately before the beginning of our timeseries, DMSPp and DMSPd concentrations were elevated at BATS. Elevated DMSP concentrations during the winter months are atypical for the Sargasso Sea. The cause of these elevated values is unclear. As discussed above, the changes in ocean physics and chemistry caused by these three events impacted the upper ocean sulfur cycling as is 
evident in both the concentrations, genomic, and rate data. These perturbations provide the opportunity to test hypotheses about the mechanisms driving upper ocean sulfur cycling.

\subsection{METHODS}

\subsubsection{Gene Abundance and Expression}

DNA and RNA were collected, extracted, and quantified monthly at BATS following the protocols described in Chapter 4. Standard curves, from serial dilutions of known gene copy number, are used to convert the quantitative polymerase chain reaction (qPCR) output to copies per reaction. This calculation relies on the assumption that standard clones and environmental samples have the same reaction efficiencies (defined and discussed in Chapter 4, section 4.3.3), such that with each PCR cycle the quantity of the target sequences in both standards and samples are increasing at the same rate. Differences in efficiency between the samples and standards could occur due to inhibition in the samples or to inefficient primer binding (discussed in Chapter 4 section 4.3.3) and could result in significant over- or underestimates of gene copy number. The efficiency for each reaction was calculated using the LinRegPCR program [Ramakers et al., 2003; Ruijter et al., 2009]. The individual efficiency is based on the increase in fluorescence in each well and is calculated as:

$\% E_{\text {ind }}=\left(10^{\text {slope }}-1\right) \times 100 \%$ 
where $\% E_{\text {ind }}$ is the percent efficiency for an individual reaction, and slope is the slope of linear fit to $\log$ (fluorescence) versus cycle number. An individual efficiency of $100 \%$ indicates that the number of gene amplicons in the sample is doubled during each cycle. For each plate, the average $\% E_{\text {ind }}$ for the environmental samples was within error of the $\% E_{\text {ind }}$ for the standards (Table 5.1). Therefore, we conclude that the standards can be used to rigorously estimate the copy number for each sample. The average efficiency (\%E), as defined by equation (2) in Chapter 4, and standard curve $\mathrm{R}^{2}$ values for each primer set are presented in Table 5.2. These efficiencies differ slightly from those presented in Table 5.1 due to differences between equation (3) and Chapter 4 equation (2). While it is necessary to use a technique such as the LinRegPCR program to calculate the efficiencies of individual samples, we have greater confidence in the average efficiency estimate (\%E) calculated using equation (2) Chapter 4 and presented in Table 5.2. All efficiencies, except for the abundance of $\mathrm{D} / 3$, are less than $100 \%$ most likely due to inefficient binding of the primers to the template. We are confident that the low efficiencies are not due to inhibition from compounds co-extracted with the environmental DNA and RNA, as the samples and standards show the same $\% E_{\text {ind }}$ (Table 5.1, see Chapter 4 section 4.3.3 for a discussion of inhibition in the BATS samples). The similarity between samples and standards and the linearity of the standard curves $\left(\mathrm{R}^{2}\right.$ greater than 0.992 and typically better than 0.997 ) allows for a robust estimate of gene copy number for the samples despite less than $100 \%$ amplification efficiency. The same primer sets show different efficiencies in the expression (reverse-transcriptase-qPCR) and abundance (qPCR) analyses (Table 5.1 and 5.2). This may be due to the different buffers 
required for the reverse-transcriptase step in RT-qPCR, which may impact the binding efficiencies of the primers to the template. However, this again is corrected for using the standards.

During qPCR analysis, the fluorescence in each reaction increases exponentially. As described in Chapter 4, this signal is proportional to the quantity of double stranded DNA present in the sample and thus can be used to calculate the starting concentration of a target amplicon. For each plate, a threshold value is selected and the cycle at which a sample reaches this threshold is determined. Samples with low concentrations of starting material will take longer to reach the fluorescence threshold and so will have a larger cycle number than samples with higher concentrations. A threshold value in the exponential phase of the amplification curves is chosen manually. The number of gene copies per liter of seawater for each sample is then calculated as:

copies $/ L=\frac{\text { copies }}{\mu l \text { template }} \times \mu$ l extracted $\times \frac{1}{L \text { filtered }}$

where $\frac{\text { copies }}{\mu l \text { template }}$ is determined using the sample cycle number and the standard curve. The error for each sample is calculated as the $1 \sigma$ standard deviation of the combination of biological and technical replicates ( $\mathrm{N}=6$ for $\mathrm{DNA}$ samples, $\mathrm{N}=4$ for $\mathrm{RNA}$ samples). The average fractional error for each primer set is presented in Table 5.2. No DNA samples were discarded. RNA samples with DNA contamination greater than $3 \%$ of the RNA signal, as determined from the no-reverse-transcriptase control (-RT) described in Chapter 4, were discarded. Of points with significant expression (defined below), only one sample analyzed for D/1 expression was discarded due to DNA contamination. 
To confirm the presence of only one amplification product, melt curves for each qPCR plate were analyzed. All DNA samples showed specific amplification with only one product displayed in the melt curve analysis. Similarly, the melt curves for RNA samples run with primers D/1 and D/3 showed specific amplification. Samples analyzed for the expression of subclade $\mathrm{A} / 1$ and $d d d P$ showed non-specific amplification in some samples, most likely due to low initial gene copy number. Each melt curve for A/1 and $d d d P$ RNA samples was carefully inspected and samples with non-specific amplification were flagged. If a peak was observed at the correct melting temperature (as determined by the standards), the environmental sample was marked as non-quantifiable "plus expression". Of the 40 samples analyzed for subclade $\mathrm{A} / 1$, quantitative data were obtained from 11 samples, 21 were marked as non-quantifiable "plus expression", and 8 showed no detectable expression. $d d d P$ expression was very low, such that the copy number could not be determined for any sample. However, 8 samples were marked as "plus expression" based on the melt curve analysis. In addition, four samples showed the slight presence of a $d d d P$ peak and so were marked as "possible-expression".

\subsubsection{DMSP Lyase Activity}

DMS production by phytoplankton and bacterial DMSP cleavage was quantified with potential DMSP lyase enzyme activity (DLA) assays as described in Chapter 4 section 4.3.2.1. These assays measure the potential for DMS production when DMSP is not limiting. The limitations of this approach are discussed in Chapter 4 section 4.5. As bacteria are dependant on the dissolved DMSP pool, we multiply the observed bacterial 
DLA by the DMSPd concentration. Phytoplankton DMS production is believed to be carried out by phytoplankton groups that have high levels of intracellular DMSP. However, as not all DMSP producers contain DMSP lyase enzymes [Niki et al., 1997], the intracellular concentration of DMSPp in DMS producing cells may not be linearly related to total water column DMSPp concentration. Therefore, we do not multiply the phytoplankton DLA activity by the observed DMSPp concentration. Bacteria and phytoplankton are believed to contain different DMSP cleavage enzymes that may act differently in the potential enzyme assay. In addition, phytoplankton DLA rates are measured on whole cell extracts whereas bacterial DLA rates are measured on whole cells (see Chapter 4 section 4.3.2.2.1). Therefore, the bacterial and phytoplankton rates are not directly comparable. However, the seasonal and vertical variability in DLA for each group provides insight into variability in DMS production and the potential chemical and physical forcings influencing the production of DMS by phytoplankton and bacteria.

As discussed in Chapter 4, the on-deck waiting time prior to analysis significantly impacts the measured bacterial and phytoplankton DLA rates. Therefore, changes less than $30 \%$ are not considered robust. However, due to the substantial variability over the 10 month time-series in both the phytoplankton and bacterial DLA, a factor of 7 and 30 respectively, most of the trends are considered significant. 


\subsection{RESULTS}

\subsubsection{DMSP degrading gene abundance}

The upper ocean sulfur cycle is an important biogeochemical process which involves numerous microbial and phytoplankton groups. Based on the Global Ocean Sampling (GOS) metagenomic database, Howard et al. [2008; 2006] hypothesize that 37$58 \%$ of all bacterioplankton contain DMSP degrading genes. Similarly, our samples indicate that up to $33 \%$ of bacterioplankton cells contain a copy of the DMSP demethylation gene $(d m d A)$ (Figure $5.3 b)$ and up to $11 \%$ of cells contain a copy of the DMS producing $d d d P$ gene (Figure 5.3c). This is a maximum estimate since we assume, as per Howard et al. [2008], that each cell carries only one gene copy. The total bacterial cell counts (cells/L) from BATS [http://bats.bios.edu/, Knap et al., 1997; Steinberg et al., 2001] as identified by 4',6-diamidino-2-phenylindole (DAPI) staining are plotted in Figure 5.3a. Gaps in Figure 5.3a at July $60 \mathrm{~m}$ and August $10 \mathrm{~m}$ are due to gaps in the BATS dataset. The symbol color corresponds to the concentration of cells. The size of the symbol (for panels b and c) is related to the inverse of the coefficient of variation, where the coefficient of variation is defined as $1 \sigma$ of abundance/abundance such that a larger symbol represents a measurement with a small fractional error. In general, cells with DMSP degradation genes make up a significant portion of the bacterial community in the late summer and early fall of 2008 when DMSPd concentrations are elevated. Similarly, the DMSP degraders are abundant in May when DMSPd concentrations are elevated most likely due to the influence of the cyclonic eddy. As discussed previously, 
the elevated DMSPp in the eddy, most likely due to a DMSP producer bloom, appears to have caused a subsequent increase in DMSPd, which in turn may have resulted in the increased abundance of bacteria with DMSP degrading genes.

The seasonal variability in the percentage of cells with DMSP degrading genes observed during 2008 is driven by changes in several different gene groups, which appear to have varied responses to the physical and chemical properties of the upper water column. The abundance of five $d m d A$ subclades, $\mathrm{D} / 1, \mathrm{D} / 3, \mathrm{~A} / 1, \mathrm{~A} / 2$, and $\mathrm{C} / 2$, and $d d d P$ were quantified using qPCR as described in Chapter 4 section 4.3.3.4. Three distinct groups emerged from the abundance data; Group I containing subclades D/3, A/1 and $d d d P$, Group II containing subclade $\mathrm{A} / 2$ and D/1, and Group III containing C/2 (Figure 5.4). Group I subclades are linearly related with $R^{2}$ values greater than 0.651 ( $p$ value less than $3 \times 10^{-10}$ ). Similarly, Group II subclades are significant positively related with an $\mathrm{R}^{2}$ value of 0.627 and $\mathrm{p}$ value of $2 \times 10^{-9}$. There is some similarity between Groups I and II as subclades $\mathrm{A} / 1$ and $\mathrm{A} / 2$ are related with an $\mathrm{R}^{2}$ value of 0.512 . However, $d m d A$ clade $\mathrm{D}$ subclades $(\mathrm{D} / 1$ and $\mathrm{D} / 3)$ are not strongly correlated, $\mathrm{R}^{2}=0.229$, again suggesting distinct populations responding to different environmental forcing. Group III, subclade $\mathrm{C} / 2$, is not significantly correlated to either Group I or Group II subclades with $\mathrm{R}^{2}$ values of $0.028,0.017,0.166,0.194$, and 0.308 and $p$ values of $0.3,0.4,0.009,0.004$, and $2 \times 10^{-4}$ for $\mathrm{A} / 1, d d d P, \mathrm{D} / 3, \mathrm{D} / 1$ and $\mathrm{A} 2$ respectively. This suggests that the chemical and physical forcings driving the distribution of Group I and Group III populations are substantially different. 
Group I's $\mathrm{A} / 1$ and $d d d P$ are highly correlated, $\mathrm{R}^{2}=0.888$, indicating that cells containing a subclade $\mathrm{A} / 1 d m d A$ gene (as defined by our primer set) are behaving similarly to cells containing a copy of $d d d P$ or even that these two genes are contained in the same cells. Previous work has shown that subclade $\mathrm{A} / 1$ and $d d d P$ both occur in Roseobacter strains [Todd et al., 2009; Varaljay et al., submitted], and that some roseobacters have the ability to both demethylate and cleave DMSP [Gonzalez et al., 1999; Howard et al., 2006; Moran et al., 2004] However, in our samples, dddP is on average 30 times more abundant than $\mathrm{A} / 1$. We suggest three different hypothesis to explain the high degree of similarity between subclade $\mathrm{A} / 1$ and $d d d P$ and the difference in abundance between these two genes. The first hypothesis is that a $d d d P$ containing roseobacter community contains a subset that has the potentially to both demethylate and cleave DMSP, i.e. contains both $\mathrm{A} / 1$ and $d d d P$ genes. Alternatively, an entire group of organisms, most likely roseobacters, contain both genes. However, our A/1 primer set may only be capturing a fraction of the $\mathrm{A} / 1$ subclade genes making $d d d P$ appear to be 30 times more abundant. This would be due to sampling limitations in the metagenomic database used to design the A/1 primer; for example the Sargasso Sea samples in the metagenomic database were collected near BATS in February and so may not fully capture the diversity of the A/1 subclade throughout the year at BATS. Finally, the A/1 and $d d d P$ genes could be contained in two completely separate populations that are responding to the same chemical and physical forcings. The similarity between $d d d P$ and A/1 is discussed further below, section 5.3.2. 
The abundance of the six DMSP degrading genes quantified in this study are plotted in Figure 5.5. The symbol color corresponds to the abundance in copies/L and

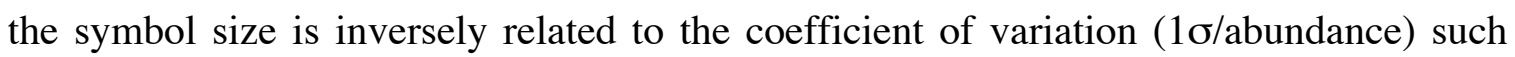
that large symbols indicate small fractional error. Clade $\mathrm{D}$ is the most abundant $d m d A$ clade in the Sargasso Sea with, on average, $10 \%$ of upper ocean cells containing a copy of the D/1 gene. Subclade D/1 (Figure 5.5a) reaches peak concentrations of $14.1 \times 10^{7}$ copies/L in May at $60 \mathrm{~m}$ and is present in significant concentrations throughout the upper water column $(<60 \mathrm{~m})$ in the late summer and fall (July through October). Both subclades $\mathrm{D} / 1$ and $\mathrm{D} / 3$ are predominantly found below $20 \mathrm{~m}$. D/3 appears to respond to mixing and upwelling events with peak concentrations observed during February (deep winter mixing), May (cyclonic eddy), and July (Hurricane Bertha). The one inconsistency is August $60 \mathrm{~m}$ where D/3 also showed elevated concentrations but no mixing or upwelling was observed. Subclade A/2 shows a similar response to mixing and upwelling events with elevated concentrations during May (cyclonic eddy) and July (Hurricane Bertha) and slightly elevated concentrations in February at 20m and 60m (deep winter mixing). However, similar to subclade D/1, A/2 also shows increased concentrations in the late summer and early fall (August through October).

Though members of the same clade, the $\mathrm{A} / 1$ and $\mathrm{A} / 2$ subclades demonstrate distinct spatial patterns with $\mathrm{A} / 2$ peaking at shallower depths $(\sim 20 \mathrm{~m})$ than $\mathrm{A} / 1(\sim 60 \mathrm{~m})$ (Figure $5.5 c$ and $d$ ). This clear spatial separation between subclades $\mathrm{A} / 1$ and $\mathrm{A} / 2$ suggests niche differentiation such as the low-light and high-light niches observed in Prochlorococcus [Moore and Chisholm, 1999]. Clade A is thought to be comprised 
primarily of members of the Roseobacter group. While subclades have been identified in the SAR11 and Prochlorococcus populations at BATS [Carlson et al., 2009; Moore and Chisholm, 1999], to date no niche defined Roseobacter subclades have been observed. The depth differentiation between the $\mathrm{A} / 1$ and $\mathrm{A} / 2$ subclades suggests that light, such as UV tolerence, may play a role in the differentiation between the two groups. Unfortunately, the temporal and spatial resolution of this study does not allow us to determine the factors driving this differentiation. High-resolution observations, such as those provided by oceanographic floats or moorings, are needed to adequately capture the driving mechanisms behind these variations.

Subclade $\mathrm{C} / 2$, believed to be harbored by SAR11 bacteria, is spatially and temporally distinct from clades D and A. Peak concentrations occur during the summer months (July and August) approximately 5-6 months after the winter mixing event. Similarly, Carlson et al. [2009] observed a seasonal succession in the SAR11 population at BATS where subclade Ia dominated the upper 40m 5-6 months after the wintertime deep mixing event. The similarity in the seasonal variations between SAR11 subclade Ia and $d m d A$ subclade $\mathrm{C} / 2$ suggests that the SAR11 subclade Ia bacterium may contain a subclade $\mathrm{C} / 2 d m d A$ gene.

The driving mechanisms behind seasonal shifts in major bacterial clades in oligotrophic regions are unknown. Total bacterial abundance in the Sargasso has a weak seasonal cycle with low abundances in the winter (December - March) and slightly 
increased abundances in the spring and summer [Carlson et al., 1996] ${ }^{7}$, similar to that observed for subclade $\mathrm{C} / 2$. The clade specific response to seasonal chemical and physical changes has only been explored for the SAR11 group [Carlson et al., 2009]. Carlson et al. conclude that SAR11 populations at BATS respond to changes in physical forcings such as seasonal mixing and stratification, which impact DOC availability [Carlson et al., 2009]. This is consistent with other work by this group which found that the bacterial community at BATS is limited by labile DOC concentrations [Carlson et al., 2002].

\subsubsection{DMSP degrading gene expression}

This study is the first time that the expression of DMSP demethylation and cleavage genes has been quantified in environmental samples. The DMSP degradation gene expression for $d m d A$ subclades $\mathrm{D} / 1, \mathrm{D} / 3$ and $\mathrm{A} / 1$ and $d d d P$ in copies/L are presented in Figure 5.6. The symbol color corresponds to the measured expression and the symbol size is related to the inverse of the coefficient of variation (1б/expression) such that larger symbols represent smaller fractional error. Samples with no detectable expression are shown as open circles, and samples with "plus expression" are denoted with a ' + '. Locations with significant $\mathrm{D} / 1, \mathrm{D} / 3, \mathrm{~A} / 1$ and $d d d P$ expression are selected

\footnotetext{
${ }^{7}$ Figure $3 a$ is consistent with the seasonal cycle of total bacterial abundance presented in Carlson et al. [1996]. Carlson et al. reports low abundances between late November and early March and a period of 'high abundance' from late March through early November with significant variability.
} 
using a cutoff of 10,000, 2000, and 40 gene copies per L and "plus expression", respectively. The following analysis focuses on these regions of significant expression.

Significant seasonal variability in DMSP degradation gene expression is observed at BATS. For all subclades quantified in this study, the fraction of cells expressing DMSP related genes (expression/abundance) was lowest in the summer and highest in the fall and winter (Figure 5.7). DMSP degradation genes showed extremely low levels of expression, with measured gene expression less than 1 transcript per 1000 gene copies. While the cyclonic eddy in May resulted in significant expression in the D/1 and D/3 subclades at $60 \mathrm{~m}$, the fractional expression for this month was no different than that observed during the summer months. The extremely low levels of expression for both the $d m d A$ and $d d d P$ genes suggests that the DMSP degrading enzymes may be long lived in the cell such that continual transcription and translation of DMSP degrading genes is not necessary.

Biogeochemically the relevant quantity is the number of gene copies expressed per liter at any given time. Significant levels of $d m d A$ expression were observed in February (deep winter mixing), May 60m (cyclonic eddy), August 60m, September 40m and October $40 \mathrm{~m}$ and $60 \mathrm{~m}$ (Figure 5.6). The following analysis will focus on the chemical and physical changes that may have resulted in significant $d m d A$ expression in these months and at these depths.

DMSP is a source of both labile carbon and reduced sulfur for bacteria in the surface ocean. Bacteria can access this carbon source through both the demethylation and cleavage pathways. It has been hypothesized that when bacterial sulfur demand is 
high and DMSP is low, the demethylation pathway, which allows bacteria to access both the carbon and sulfur in DMSP, will be the dominant DMSP degradation pathway. Alternatively when DMSP concentrations are high or sulfur demand is low, it has been hypothesized that the DMSP cleavage pathway, which only provides labile carbon, will be favorable. However, the 'bacterial switch' was not observed during this study. Rather, the expression of both pathways (as defined by the $d m d A$ and $d d d P$ genes) tended to be elevated at the same location and concurrent with elevated DMSPd concentrations (Figure 5.8b). Exceptions occur during February and May, which are discussed below.

While the expression of $d d d P$ and $d m d A$ clades $\mathrm{D} / 1, \mathrm{D} / 3$, and $\mathrm{A} / 1$ in the late summer and early fall corresponds to elevated DMSPd concentrations, there are other periods with similarly high DMSPd concentrations that do not have significant expression of DMSP degrading genes. We suggest that this may be in part due to UV inhibition of the DMSP demethylation pathway and in part due to community composition and bacterial dynamics. $d m d A$ expression for the subclades quantified in this study appears to be light sensitive with significant expression occurring below the mixed layer, with the exception of February during which time deep mixing resulted in low UV radiation dose. This is consistent with previous findings which conclude that UV radiation inhibits DMSPd consumption [Slezak et al., 2001; Slezak et al., 2007]. In addition, preliminary studies suggest that the DMSP demethylation pathway may produce reactive oxygen species (ROS) thereby making it unfavorable under conditions which also increase intracellular concentrations of reactive oxygen species, e.g. UV stress [S. Gifford, unpublished]. 
Chemical parameters such as carbon availability appear to have a secondary impact on $d m d A$ expression. The upward displacement of thermocline waters in May as a result of the cyclonic eddy, resulted in low labile TOC concentrations at $60 \mathrm{~m}$ (Figure 5.1d). This decrease in labile TOC compounded with a high bacterial carbon demand (quantified following the protocol presented in Chapter 4 section 4.3.1) may explain why significant expression is observed at May 60m and not May 40m, June 40m, June 60m and July 60m, which all show similar DMSPd concentrations but elevated TOC concentrations. The absence of significant expression during June at 40 and $60 \mathrm{~m}$ could also simply be explained by low bacterial activity as quantified by bacterial demand (Figure 5.8a).

Subclades $\mathrm{D} / 1$ and $\mathrm{D} / 3$ are significantly expressed at the same locations except for September and October $40 \mathrm{~m}$ where $\mathrm{D} / 1$ is significantly expressed and $\mathrm{D} / 3$ is not. This is likely due to the extremely low abundance of $\mathrm{D} / 3$ at $40 \mathrm{~m}$ during these months such that even elevated levels of expression would be below the detection limit of our analysis. Similarly, other than February (discussion to follow) A/1 is only significantly expressed in October at $40 \mathrm{~m}$ and $60 \mathrm{~m}$. This corresponds to the highest observed DMSPd concentrations. The abundance of subclade $\mathrm{A} / 1$ is an order of magnitude lower than that of subclade $\mathrm{D} / 1$. Therefore, similar to subclade $\mathrm{D} / 3$, even significant levels of expression may not be detectable in August and September. However, it is interesting that $d d d P$ expression is observed at all the locations where subclade $\mathrm{D} / 1$ is significantly expressed including those where $\mathrm{A} / 1$ is not significantly expressed. As discussed above, the abundance of $\mathrm{A} / 1$ and $d d d P$ are highly correlated suggesting that the genes are contained 
in the same population. Therefore, it may only be advantageous for the subset of the population with the $\mathrm{A} / 1$ gene to upregulate both pathways when DMSPd concentrations are extremely high. This would explain why the A/1 gene only shows significant expression under high DMSPd concentrations (such as Oct 40m and 60m).

In February, DMSPd concentrations, bacterial demand, and labile TOC are low. While DMSP gene abundance is also low during this month, all $d m d A$ clades were significantly expressed and $d d d P$ was "possibly expressed". The driving mechanism behind this expression is unclear. As discussed above, January 2008 showed atypically high DMSPp and DMSPd concentrations. While upper ocean sulfur cycling is too rapid for increases in January to account for the observed expression in February, it is possible that a combination of factors including the anomoluous January conditions contributed to high levels of expression in February. Specifically, the bacterial community in the wintertime at BATS is carbon starved due to low semi-labile TOC concentrations. Therefore, the drastic increase of DMSPd in January and the residual elevated DMSPd concentrations in February may have been a sufficient enough increase, relative to the alternative carbon sources, for DMSP degraders to upregulate and maintain the DMSP degradation pathway. In addition, UV radiation dose is low in February due to low surface irradiance and deep mixed layers such that any possible inhibition or unfavorable conditions due to UV stress would be eliminated. The combination of these factors may provide a partial explanation for the high level of expression of the DMSP degrading genes in February. 


\subsubsection{DMS production: potential enzyme activity}

Bacterial DMS production, as measured by the DLA assay, is highest in the late summer and early fall between $20 \mathrm{~m}$ and 60m (Figure 5.9a). High bacterial DMS production corresponds to high water column DMSPd concentrations and elevated expression of DMSP degradation genes suggesting that bacterial DMS production is controlled by water column DMSPd concentrations and community composition, as defined by gene abundance and expression. There is however a slight disconnect between $d d d P$ expression and bacterial DMS production. Bacterial DMS production is high in September between $20 \mathrm{~m}$ and $60 \mathrm{~m}$ whereas $d d d P$ is only expressed at $40 \mathrm{~m}$ (Figure 5.9a). Conversely, $d d d P$ is expressed in March 40m, May 60m, October 20m, and November $40 \mathrm{~m}$ where bacterial DMS production is low. The lack of $d d d P$ expression at locations where significant bacterial DLA rates were measured and presence of $d d d P$ expression at locations where DLA was not measured may indicate that the bacterial DLA method does not accurately quantify DMS production from $d d d P$ enzymes or that $d d d P$ may not be the primary bacterial DMSP cleavage gene at BATS. However, it is more likely that these differences are due to the longevity of DMSP cleavage enzymes such that at any given point in time only a small fraction of cells are actively transcribing the $d d d P$ gene making this expression difficult to detect. Alternatively, post transcriptional regulation may degrade the transcript before the protein is made resulting in the observed disconnect between $d d d P$ gene expression and DLA activity.

Phytoplankton DLA is highest in surface waters in the summer and early fall concurrent with the shoaling of the mixed layer and high UV radiation dose in the upper 
water column (Figure 5.9b). This is consistent with previous studies which suggest that phytoplankton cleave DMSP to DMS as an anti-oxidant response to UV radiation [Sunda et al., 2002]. The low phytoplankton DLA observed in July is also consistent with an anti-oxidant response as the deep mixed layers caused by Hurricane Bertha reduce the UV radiation experienced by the surface phytoplankton. Bacterial DLA also decreases in July, albeit a small one, suggesting a potential role for UV stress in bacterial DMS production.

\subsection{DISCUSSION: A mechanistic explanation of the upper ocean sulfur cycle}

The combination of chemical, physical, and biological measurements made during this study provides insight into the driving mechanisms behind variability in the upper ocean sulfur cycle. Here we present a modified conceptual model for organic sulfur cycling in oligotrophic regions. Particulate DMSP is produced in phytoplankton cells in response to environmental stress (see literature review in Chapter 4 section 4.1.1). This particulate pool is either cleaved by phytoplankton to DMS (discussed below) or released into the water column through cell senescence and grazing where it is rapidly cycled by the bacterial community. When dissolved DMSP concentrations are

elevated, the bacterial community responds by up-regulating DMSP degradation pathways. The DMSP demethylation pathway primarily occurs below the mixed layer 
$\left(40-60 \mathrm{~m}^{8}\right)$ possibly due to UV inhibition in surface waters whereas the DMSP cleavage pathway is found both above and below the mixed layer. The expression of $d m d A$ and $d d d P$ corresponds to areas of elevated DMSPd consumption, as measured by radioisotope analysis (Chapter 4 section 4.3.1) (Figure 5.8c). However, no significant upper water column gene expression was observed. Specifically, the high rates of DMSPd consumption measured in May and August above 40m do not correlate to significant $d m d A$ expression, $d d d P$ expression or bacterial DLA. This suggests that there may be DMSP demethylation or lyase activity that is not captured by the assays used in this study. It is possible that this additional DMSPd consumption is due to subclade $\mathrm{C} / 2$ or $\mathrm{A} / 2$ activity, both of which show elevated concentrations in the upper water column (the choice of subclades for expression analysis is discussed in Chapter 4, section 4.3.3.4). The spatial distribution of these subclades (Figure 5.5) suggest that they may be highlight adapted and so may not have the same postulated UV inhibition seen in subclades $\mathrm{D} / 1, \mathrm{D} / 3$ and $\mathrm{A} / 1$. Alternatively, a different DMSP cleavage gene (either $d d d D, d d d L$, or another unidentified gene) may be responsible for the DMSPd consumption in these areas. Similarly, it is also possible that the bacterial DLA assay only measures DMS production from a sub-set of the bacterial community. Several different DMSP cleaving mechanisms have been identified in bacteria [Curson et al., 2008; Todd et al., 2009; Todd et al., 2007]. We were unable to determine if the bacterial DLA assay quantifies the activity of all types of bacterial DMSP cleaving enzymes, therefore this assay may be preferentially select one enzyme type. If this were the case, some of the DMSPd

\footnotetext{
${ }^{8}$ Due to limited vertical sampling, we do not have DMSP demethylation data below $60 \mathrm{~m}$.
} 
consumption observed in the surface waters in May and August may be due to bacterial DMS production by a population containing a different enzyme system.

Phytoplankton show the highest DMSP lyase activity in the early summer (May and June) whereas bacterial DLA is highest in the late summer and early fall (September and October). Surface DMS concentrations peak in June at $25 \mathrm{~m}$, decrease due to Hurricane Bertha in July, and peak again in September between $15 \mathrm{~m}$ and $25 \mathrm{~m}$. Figure 5.10 plots DMS concentrations and DMS phytoplankton and bacterial production at $20 \mathrm{~m}$. The two peaks in water column DMS, May and September, are shown to correlate with elevated DMS production. While it is not possible to determine the exact contributions of the phytoplankton and bacterial populations to water column DMS from the DLA assays, it appears that the initial increase in DMS is due to phytoplankton DMS production whereas, later in the summer, water column DMS is derived from both phytoplankton and bacteria. The absence of DMS below 30m despite the presence of DMSP lyase enzyme activity can be explained by bacterial DMS consumption. Radioisotope experiments show that the rate of DMS consumption is high in subsurface waters (Figure 5.1f), while the standing stock of DMS at these depths is essentially zero. This is indicative of rapid cycling where high production is coupled with high consumption, such that any DMS produced is rapidly stripped out of the water column resulting in low standing stocks. Bacterial DMS consumption is thought to be inhibited by UV radiation, thereby de-coupling DMS production and consumption in the surface waters and contributing to the observed summertime increase in DMS. In addition, photolysis rates are highest in the surface waters and decrease with depth providing a 
possible explanation for the absence of DMS above $20 \mathrm{~m}$ despite measured DMSP lyase enzyme activity.

While the importance of bacteria in DMS(P) cycling in the surface ocean has been established [e.g. Kiene et al., 2000], the bacterial contribution to water column DMS concentrations and seasonal DMS(P) dynamics has been poorly understood. This study suggests that bacterial DMS production in oligotrophic regions varies substantially over the course of a 10 month period and may significantly contribute to water column DMS concentrations in the late summer and early fall. We believe that previous studies may have underestimated the importance of bacterial DMS production due to methodological problems such as dimethyl disulfide additions to ${ }^{35} \mathrm{~S}$ tracer methods (see Chapter 4 , section 4.3.2.2.7). In addition, the relative expression of the two bacterial DMSP degradation pathways appears to be less dependent on available carbon supply and more dependent on community composition (gene abundance) and UV radiation stress. Finally, the hypothesized correlation between UV radiation stress and phytoplankton DMSP lyase activity was supported by the phytoplankton DLA measurements that showed higher summertime values concurrent with the shoaling of the mixed layer. Phytoplankton lyase activity was not constant throughout the summer season. Rather, phytoplankton DMS production was shown to be greatest in the spring and early summer and lower in the late summer and early fall, concurrent with increased bacterial DMS production. 


\subsection{CONCLUSION}

This work suggests a modified conceptual model for the upper ocean sulfur cycle with a seasonal succession of the dominant functional groups involved, from phytoplankton in the early summer to bacteria in the late summer and early fall. This maybe due to the increased release of DMSP from phytoplankton into the water column during this time period that in turn triggers a bloom of DMSP consumers. This work also identifies a diverse bacterial community that is active in cycling organic sulfur in the surface ocean. There appears to be niche differentiation in the $d m d A$ A subclades with the suggestion of subsurface and surface subclades, which are potentially low UV and high UV adaptive, respectively. Further work is needed to conclusively demonstrate the hypotheses presented in this chapter. Field and laboratory perturbation experiments testing the response of $d m d A$ and $d d d P$ gene expression and bacterial and phytoplankton DLA rates to UV stress and DMSPd amendments would provide further insight the relationships observed during the ten month BATS time-series. In addition, field studies observing changes in phytoplankton and bacterial DMS production during different seasons is needed to elucidate the possibility of a seasonal succession in DMS(P) cycling.

Current upper ocean sulfur cycle models either do not include bacterial DMSP degradation and DMS production or parameterize bacterial DMS production as a static percentage yield of DMSPd consumption, where DMSPd consumption is scaled to bacterial production and total bacterial abundance [e.g. Toole et al., 2008]. The results of

this study suggest that there are fundamental inaccuracies in the current assumptions used 
in numerical sulfur models. Specifically, we suggest that a dynamic bacterial component is needed to accurately represent the seasonal dynamics of DMSP consumption and DMS production. As shown in Figure 5.3, 5.8, and 5.9, bacterial DMSPd consumption and DMS production cannot be predicted from total bacterial abundance and bacterial carbon demand (which scales with bacterial production) alone. We suggest that several factors need to be considered to accurately represent bacterial DMS(P) cycling; specifically DMSPd concentrations, UV radiation stress, community composition (gene abundance), and bacterial carbon demand. Of these parameters, shifts in community composition is the most difficult to incorporate into a numerical model.

The genetic analysis conducted in this study suggests that a diverse group of bacterial populations are responsible for DMSP degradation in the Sargasso Sea. However, the expression of DMSP degrading genes showed similar trends across all clades and subclades (Figure 5.8b). Therefore, it would be sufficient for numerical models to capture the integrated effect of the bacterial community rather than specifically modeling the dynamics of each subclade. The dominant pattern observed during 2008 was a shift to a higher fraction of the bacterial community containing DMSP degradation genes and greater DMSP degradation gene expression during the summer and early fall concurrent with increased DMSPd concentrations. Therefore, we suggest that parameterizing bacterial DMSP degradation based on seasonal variations in DMSPd concentrations (related to DMSPp concentrations, Figure 5.2), bacterial carbon demand and UV radiation stress would allow for a dynamic bacterial component in upper ocean sulfur models and improve predictions of DMS(P) cycling. 


\subsection{ACKNOWLEDGEMENTS:}

We would like to acknowledge funding from National Science Foundation (NSF) grants OCE-0525928, OCE-072417, and OCE-042516. Additional funding was provided by the Center for Microbial Oceanography Research and Education (CMORE) an NSF Science and Technology Center (EF-0424599), the Gordon and Betty Moore Foundation, the Scurlock Fund, and the Ocean Ventures Fund.

\subsection{REFERENCES}

Carlson, C. A., H. W. Ducklow, and A. F. Michaels (1994), Annual flux of dissolved organic-carbon from the euphotic zone in the northwestern Sargasso Sea, Nature, 371(6496), 405-408.

Carlson, C. A., H. W. Ducklow, and T. D. Sleeter (1996), Stocks and dynamics of bacterioplankton in the northwestern Sargasso Sea, Deep-Sea Research Part Ii-Topical Studies in Oceanography, 43(2-3), 491-515.

Carlson, C. A., H. W. Ducklow, D. A. Hansell, and W. O. Smith (1998), Organic carbon partitioning during spring phytoplankton blooms in the Ross Sea polynya and the Sargasso Sea, Limnology and Oceanography, 43(3), 375-386.

Carlson, C. A., R. Morris, R. Parsons, A. H. Treusch, S. J. Giovannoni, and K. Vergin (2009), Seasonal dynamics of SAR11 populations in the euphotic and mesopelagic zones of the northwestern Sargasso Sea, Isme Journal, 3(3), 283-295.

Carlson, C. A., S. J. Giovannoni, D. A. Hansell, S. J. Goldberg, R. Parsons, M. P. Otero, K. Vergin, and B. R. Wheeler (2002), Effect of nutrient amendments on bacterioplankton production, community structure, and DOC utilization in the northwestern Sargasso Sea, Aquatic Microbial Ecology, 30(1), 19-36.

Curson, A. R. J., R. Rogers, J. D. Todd, C. A. Brearley, and A. W. B. Johnston (2008), Molecular genetic analysis of a dimethylsulfoniopropionate lyase that liberates the climate-changing gas dimethylsulfide in several marine alpha-proteobacteria and Rhodobacter sphaeroides, Environmental Microbiology, 10(3), 757-767. 
Gonzalez, J. M., R. P. Kiene, and M. A. Moran (1999), Transformation of sulfur compounds by an abundant lineage of marine bacteria in the alpha-subclass of the class Proteobacteria, Applied and Environmental Microbiology, 65(9), 3810-3819.

Hansell, D. A., and C. A. Carlson (1998), Net community production of dissolved organic carbon, Global Biogeochemical Cycles, 12(3), 443-453.

Howard, E. C., S. L. Sun, E. J. Biers, and M. A. Moran (2008), Abundant and diverse bacteria involved in DMSP degradation in marine surface waters, Environmental Microbiology, 10(9), 2397-2410.

Howard, E. C., et al. (2006), Bacterial taxa that limit sulfur flux from the ocean, Science, 314(5799), 649-652.

Kiene, R. P., L. J. Linn, and J. A. Bruton (2000), New and important roles for DMSP in marine microbial communities, Journal of Sea Research, 43(3-4), 209-224.

Knap, A. H., et al. (1997), Bermuda Atlantic Time-series Study Methods Manual Version 4Rep., U.S. JGOFS Planning Office, Woods Hole.

Malmstrom, R. R., R. P. Kiene, and D. L. Kirchman (2004a), Identification and enumeration of bacteria assimilating dimethylsulfoniopropionate (DMSP) in the North Atlantic and Gulf of Mexico, Limnology and Oceanography, 49(2), 597-606.

Malmstrom, R. R., R. P. Kiene, M. T. Cottrell, and D. L. Kirchman (2004b), Contribution of SAR11 bacteria to dissolved dimethylsulfoniopropionate and amino acid uptake in the North Atlantic ocean, Applied and Environmental Microbiology, 70(7), 4129-4135.

McGillicuddy, D. J., L. A. Anderson, S. C. Doney, and M. E. Maltrud (2003), Eddydriven sources and sinks of nutrients in the upper ocean: Results from a 0.1 degrees resolution model of the North Atlantic, Global Biogeochemical Cycles, 17(2).

McGillicuddy, D. J., A. R. Robinson, D. A. Siegel, H. W. Jannasch, R. Johnson, T. Dickeys, J. McNeil, A. F. Michaels, and A. H. Knap (1998), Influence of mesoscale eddies on new production in the Sargasso Sea, Nature, 394(6690), 263-266.

Moore, L. R., and S. W. Chisholm (1999), Photophysiology of the marine cyanobacterium Prochlorococcus: Ecotypic differences among cultured isolates, Limnology and Oceanography, 44(3), 628-638. 
Moran, M. A., et al. (2004), Genome sequence of Silicibacter pomeroyi reveals adaptations to the marine environment, Nature, 432(7019), 910-913.

Niki, T., M. Kunugi, K. Kohata, and A. Otsuki (1997), Annual monitoring of DMSproducing bacteria in Tokyo Bay, Japan, in relation to DMSP, Marine Ecology-Progress Series, 156, 17-24.

Ramakers, C., J. M. Ruijter, R. H. L. Deprez, and A. F. M. Moorman (2003), Assumption-free analysis of quantitative real-time polymerase chain reaction (PCR) data, Neuroscience Letters, 339(1), 62-66.

Ruijter, J. M., C. Ramakers, W. M. H. Hoogaars, Y. Karlen, O. Bakker, M. J. B. van den Hoff, and A. F. M. Moorman (2009), Amplification efficiency: linking baseline and bias in the analysis of quantitative PCR data, Nucleic Acids Research, 37(6).

Simo, R., and C. Pedros-Alio (1999), Role of vertical mixing in controlling the oceanic production of dimethyl sulphide, Nature, 402(6760), 396-399.

Slezak, D., A. Brugger, and G. J. Herndl (2001), Impact of solar radiation on the biological removal of dimethylsulfoniopropionate and dimethylsulfide in marine surface waters, Aquatic Microbial Ecology, 25(1), 87-97.

Slezak, D., R. P. Kiene, D. A. Toole, R. Simo, and D. J. Kieber (2007), Effects of solar radiation on the fate of dissolved DMSP and conversion to DMS in seawater, Aquatic Sciences, 69(3), 377-393.

Sprintall, J., and M. Tomczak (1992), EVIDENCE OF THE BARRIER LAYER IN THE SURFACE-LAYER OF THE TROPICS, Journal of Geophysical Research-Oceans, 97(C5), 7305-7316.

Steinberg, D. K., C. A. Carlson, N. R. Bates, R. J. Johnson, A. F. Michaels, and A. H. Knap (2001), Overview of the US JGOFS Bermuda Atlantic Time-series Study (BATS): a decade-scale look at ocean biology and biogeochemistry, Deep-Sea Research Part IiTopical Studies in Oceanography, 48(8-9), 1405-1447.

Sunda, W., D. J. Kieber, R. P. Kiene, and S. Huntsman (2002), An antioxidant function for DMSP and DMS in marine algae, Nature, 418(6895), 317-320.

Todd, J. D., A. R. J. Curson, C. L. Dupont, P. Nicholson, and A. W. B. Johnston (2009), The dddP gene, encoding a novel enzyme that converts dimethylsulfoniopropionate into 
dimethyl sulfide, is widespread in ocean metagenomes and marine bacteria and also occurs in some Ascomycete fungi, Environmental Microbiology, 11(6), 1376-1385.

Todd, J. D., R. Rogers, Y. G. Li, M. Wexler, P. L. Bond, L. Sun, A. R. J. Curson, G. Malin, M. Steinke, and A. W. B. Johnston (2007), Structural and regulatory genes required to make the gas dimethyl sulfide in bacteria, Science, 315(5812), 666-669.

Toole, D. A., D. A. Siegel, and S. C. Doney (2008), A light-driven, one-dimensional dimethylsulfide biogeochemical cycling model for the Sargasso Sea, Journal of Geophysical Research-Biogeosciences, 113(G2).

Toole, D. A., D. J. Kieber, R. P. Kiene, D. A. Siegel, and N. B. Nelson (2003), Photolysis and the dimethylsulfide (DMS) summer paradox in the Sargasso Sea, Limnology and Oceanography, 48(3), 1088-1100.

Toole, D. A., D. Slezak, R. P. Kiene, D. J. Kieber, and D. A. Siegel (2006), Effects of solar radiation on dimethylsulfide cycling in the western Atlantic Ocean, Deep-Sea Research Part I-Oceanographic Research Papers, 53(1), 136-153.

Vallina, S. M., and R. Simo (2007), Strong relationship between DMS and the solar radiation dose over the global surface ocean, Science, 315, 506-508.

Varaljay, V., E. C. Howard, S. Sun, and M. A. Moran (submitted), Deep sequencing of a DMSP-degradgin gene (dmdA) using PCR primer pairs designed from marine metagenomic data.

Vila-Costa, M., J. Pinhassi, C. Alonso, J. Pernthaler, and R. Simo (2007), An annual cycle of dimethylsulfoniopropionate-sulfur and leucine assimilating bacterioplankton in the coastal NW Mediterranean, Environmental Microbiology, 9(10), 2451-2463. 
Table 5.1: The average individual efficiencies (equation 1) and $1 \sigma$ error for the samples and standards from each primer set by plate. Individual efficiencies could not be calculated for the dddP expression plates due to the low gene copy number.

\begin{tabular}{|c|c|c|}
\hline & $\begin{array}{c}\text { \% Efficiency } \\
\text { Samples }\end{array}$ & $\begin{array}{c}\text { \% Efficiency } \\
\text { Standards }\end{array}$ \\
\hline Abundance & $(N=78-80)$ & $(N=12)$ \\
\hline A/1: plate 1 & $77 \pm 7 \%$ & $85 \pm 15 \%$ \\
\hline plate 2 & $67 \pm 5 \%$ & $75 \pm 8 \%$ \\
\hline plate 3 & $71 \pm 9 \%$ & $80 \pm 5 \%$ \\
\hline A/2: plate 1 & $82 \pm 6 \%$ & $88 \pm 4 \%$ \\
\hline plate 2 & $77 \pm 8 \%$ & $90 \pm 5 \%$ \\
\hline plate 3 & $76 \pm 7 \%$ & $83 \pm 5 \%$ \\
\hline C/2: plate 1 & $57 \pm 6 \%$ & $62 \pm 4 \%$ \\
\hline plate 2 & $87 \pm 9 \%$ & $82 \pm 7 \%$ \\
\hline plate 3 & $65 \pm 7 \%$ & $68 \pm 9 \%$ \\
\hline D/1: plate 1 & $86 \pm 7 \%$ & $92 \pm 7 \%$ \\
\hline plate 2 & $79 \pm 8 \%$ & $87 \pm 8 \%$ \\
\hline plate 3 & $83 \pm 8 \%$ & $87 \pm 6 \%$ \\
\hline D/3: plate 1 & $84 \pm 6 \%$ & $87 \pm 5 \%$ \\
\hline plate 2 & $86 \pm 6 \%$ & $88 \pm 4 \%$ \\
\hline plate 3 & $85 \pm 7 \%$ & $88 \pm 5 \%$ \\
\hline dddP: plate 1 & $79 \pm 5 \%$ & $80 \pm 5 \%$ \\
\hline plate 2 & $74 \pm 7 \%$ & $80 \pm 6 \%$ \\
\hline plate 3 & $74 \pm 9 \%$ & $83 \pm 8 \%$ \\
\hline Expression & $(N=71-80)$ & $(N=11-12)$ \\
\hline A/1: plate 1 & $80 \pm 3 \%$ & $84 \pm 2 \%$ \\
\hline plate 2 & $81 \pm 4 \%$ & $86 \pm 2 \%$ \\
\hline D/1: plate 1 & $80 \pm 7 \%$ & $87 \pm 5 \%$ \\
\hline plate 2 & $85 \pm 4 \%$ & $88 \pm 4 \%$ \\
\hline D/3: plate 1 & $85 \pm 5 \%$ & $87 \pm 3 \%$ \\
\hline plate 2 & $83 \pm 3 \%$ & $86 \pm 3 \%$ \\
\hline dddP & -- & -- \\
\hline
\end{tabular}


Table 5.2: The efficiency, standard curve $\mathrm{R}^{2}$ values, and fractional error for qPCR samples. The $\%$ efficiency and standard curve $\mathrm{R}^{2}$ values are the average values for all plates run with the same primer set $(\mathrm{N}=3$ for abundance analysis, $\mathrm{N}=4$ for expression analysis). The fractional error is the average fractional error for all the samples run with the same primer set $(\mathrm{N}=40)$.

\begin{tabular}{|c|c|c|c|}
\hline & $\begin{array}{c}\% \\
\text { Efficiency }\end{array}$ & $\begin{array}{c}\text { Standard } \\
\text { curve } \mathbf{R}^{\mathbf{2}}\end{array}$ & $\begin{array}{c}\text { fractional } \\
\text { error }\end{array}$ \\
\hline Abundance & & & \\
\hline $\mathrm{A} / 1$ & $80 \%$ & 0.998 & 0.22 \\
\hline $\mathrm{A} / 2$ & $89 \%$ & 0.998 & 0.24 \\
\hline $\mathrm{C} / 2$ & $84 \%$ & 0.997 & 0.21 \\
\hline $\mathrm{D} / 1$ & $81 \%$ & 0.999 & 0.21 \\
\hline $\mathrm{D} / 3$ & $100 \%$ & 0.996 & 0.27 \\
\hline$d d d P$ & $82 \%$ & 0.999 & 0.23 \\
\hline & & & \\
\hline Expression & & & 0.51 \\
\hline $\mathrm{A} / 1$ & $92 \%$ & 0.998 & 0.46 \\
\hline $\mathrm{D} / 1$ & $98 \%$ & 0.996 & 0.26 \\
\hline $\mathrm{D} / 3$ & $92 \%$ & 0.998 & -- \\
\hline$d d d P$ & $80 \%$ & 0.997 & \\
\hline
\end{tabular}



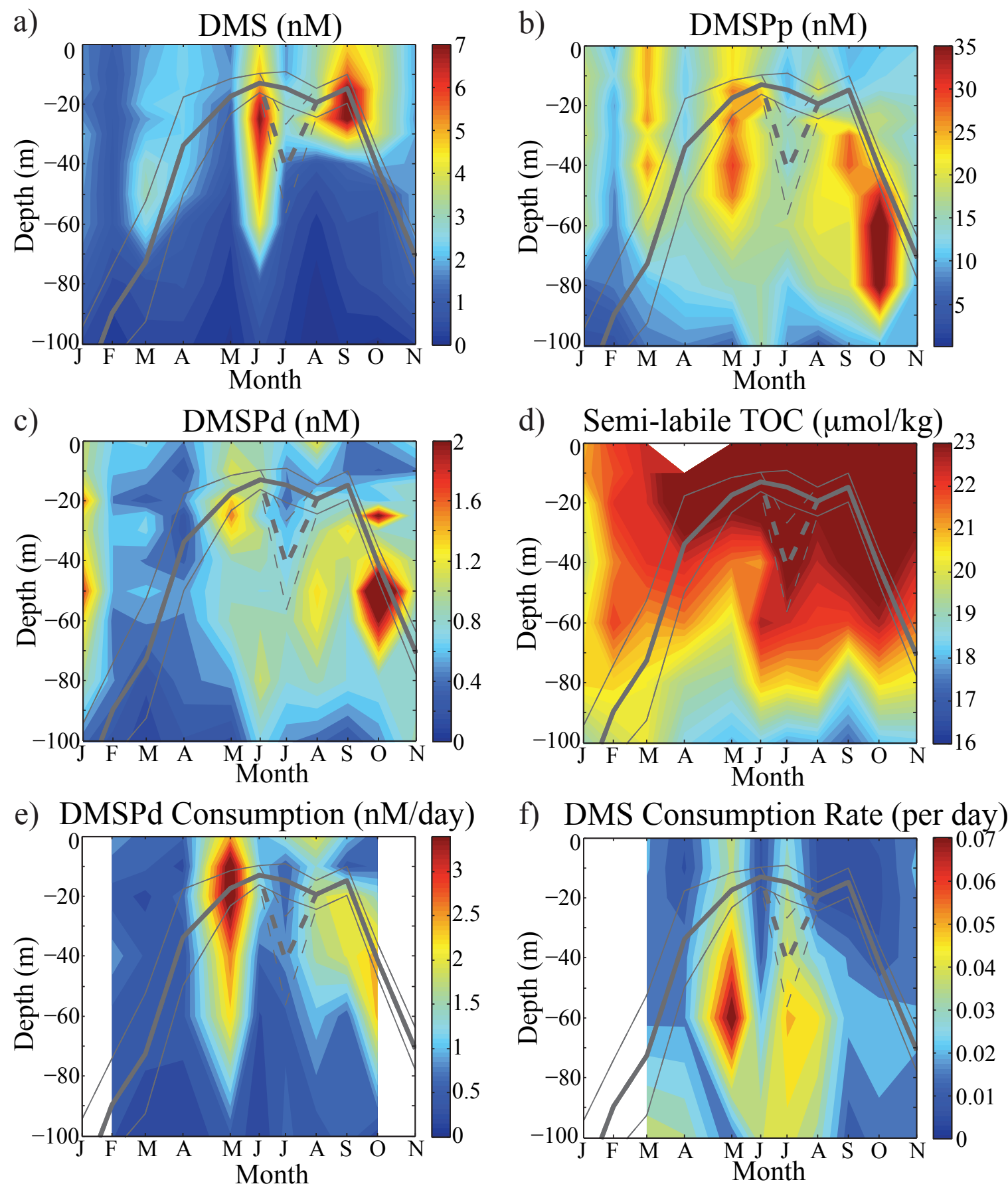

Figure 5.1: Seasonal variability in the upper ocean sulfur cycle at BATS in 2008 (January-November). The concentrations of DMS, DMSPp and DMSPd in nM are given in panels a), b) and c) respectively. Semi-labile total organic carbon (TOC) concentrations in $\mu \mathrm{mol} / \mathrm{kg}$ are given in panel d). The rate of DMSPd consumption in $\mathrm{nM} /$ day is plotted in panel e) and the specific loss rate of DMS in per day is plotted in panel f). The thick solid gray lines indicate the mixed layer depth and the thin solid gray lines represent the 1 $\sigma$ variation of the mixed layer, as defined in the text. The dashed gray lines show the deepening of the mixed layer due to Hurricane Bertha. 


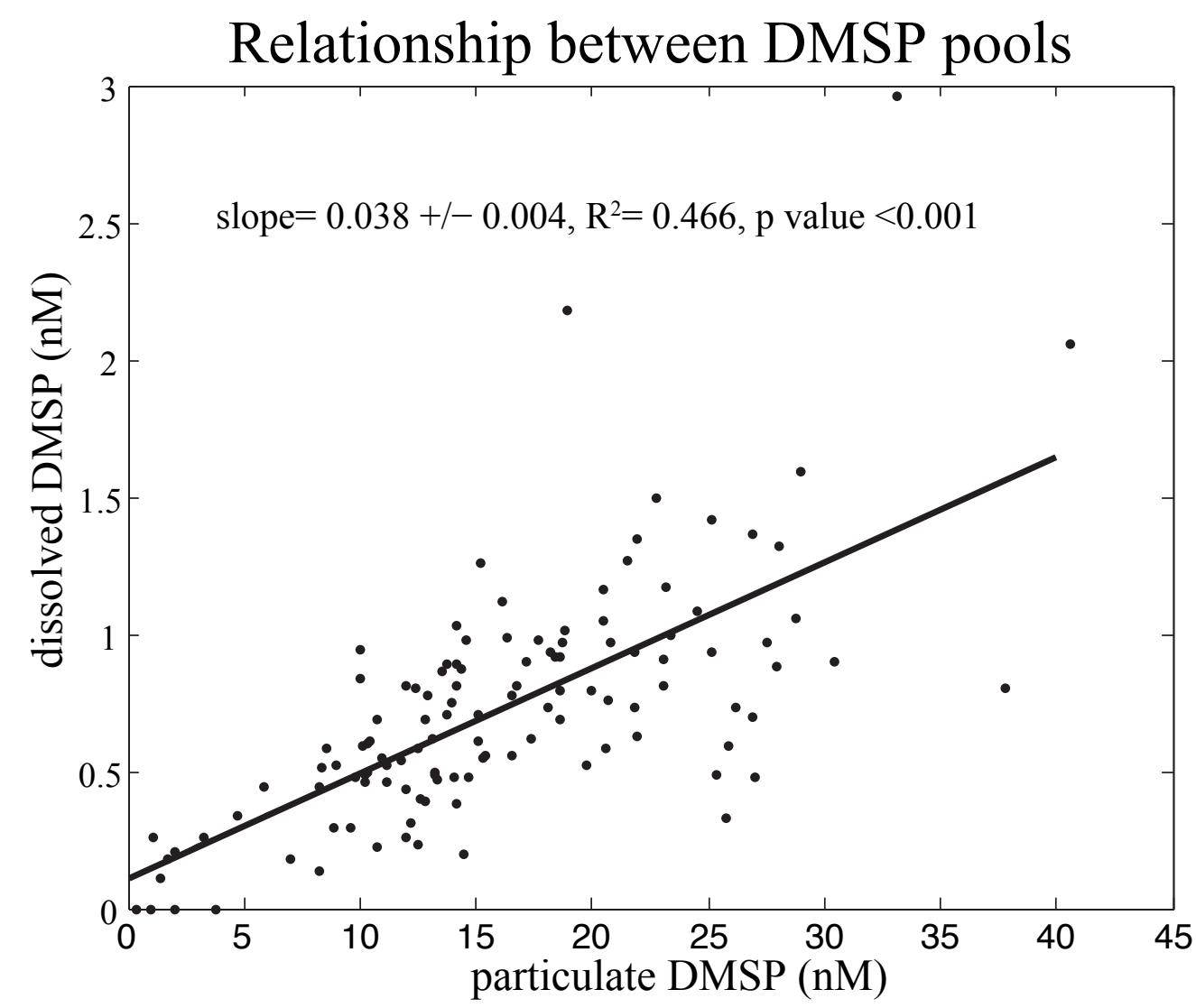

Figure 5.2: The relationship between particulate DMSP (DMSPp) and dissolved DMSP (DMPSd). Samples are from monthly observations (February-November) in the upper $140 \mathrm{~m}$ at BATS. The concentrations of both DMPSd and DMPSp are given in $\mathrm{nM}$. 
a)

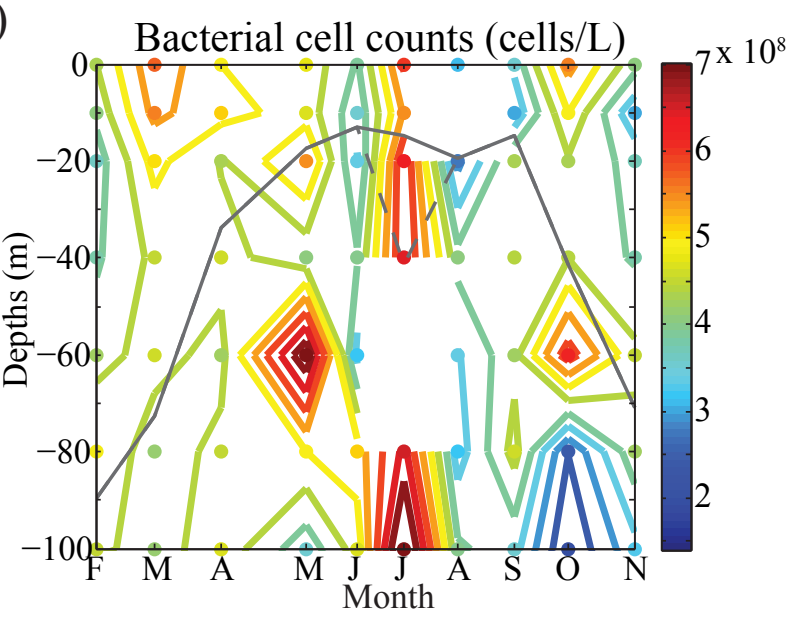

b) Fraction of total cells with $d m d A$ : $\max .33$

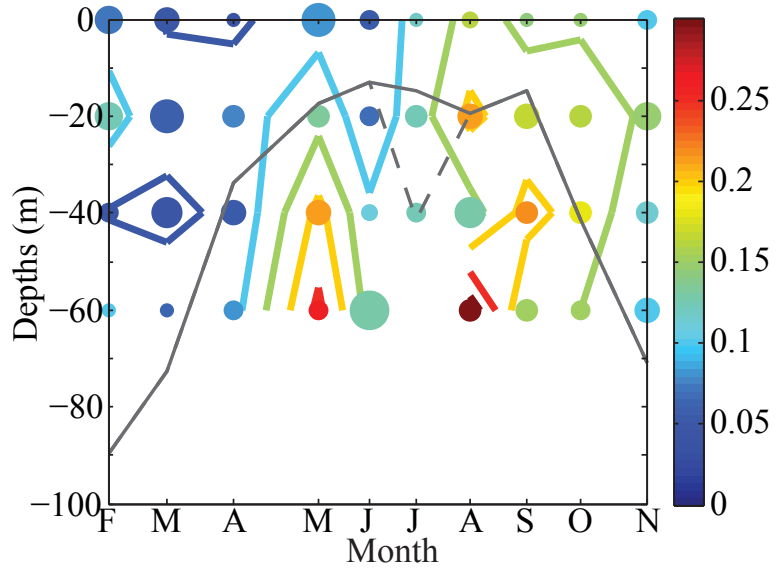

c) Fraction of total cells with $d d d P: \max .11$

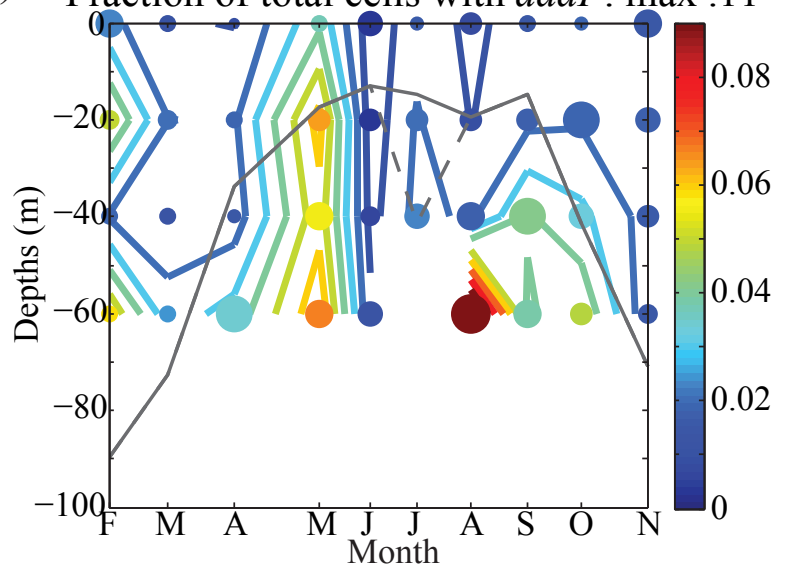

Figure 5.3: Fraction of cells with DMSP degrading genes. Panel a) plots the concentration of bacterial cells in cells/L as identified by DAPI staining. Panels b) and c) plot the fraction of total cells with $d m d A$ and $d d d P$ genes, respectively. The symbol color for all panels corresponds to the concentration of cells or fractional abundance of cells. The size of the symbol for panels $b$ and $c$ is related to the inverse of the coefficient of variation of the measurement such that larger symbols indicate measurements with small error. The mixed layer depths are plotted in gray and the dashed line shows the remnant mixed layer from Hurricane Bertha. Gaps in Figure $3 \mathrm{a}$ at July $60 \mathrm{~m}$ and August $10 \mathrm{~m}$ are due to gaps in the BATS dataset. 
a)

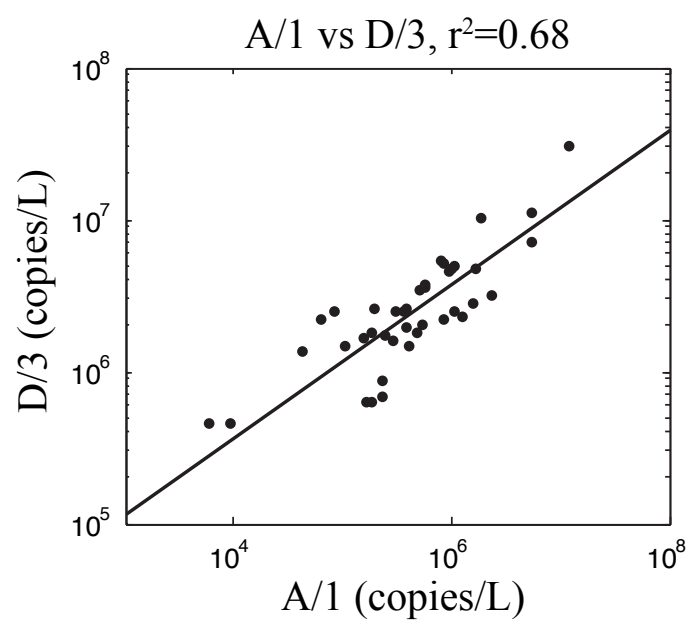

c)

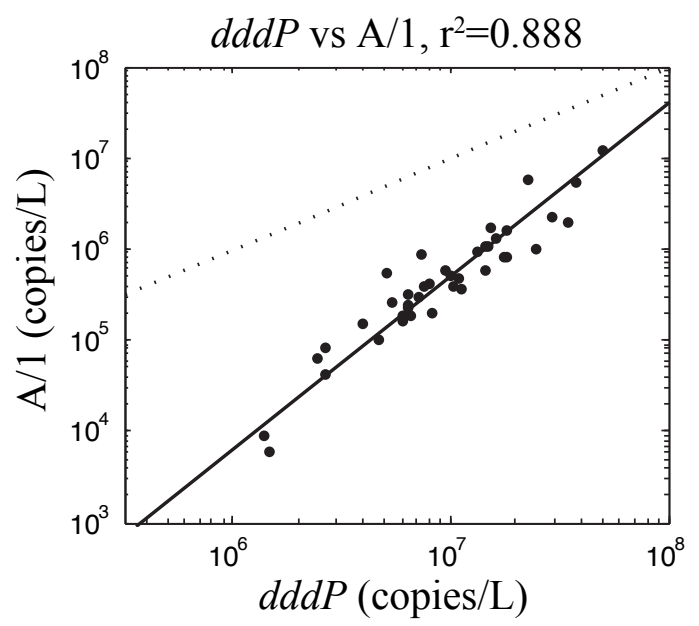

e)

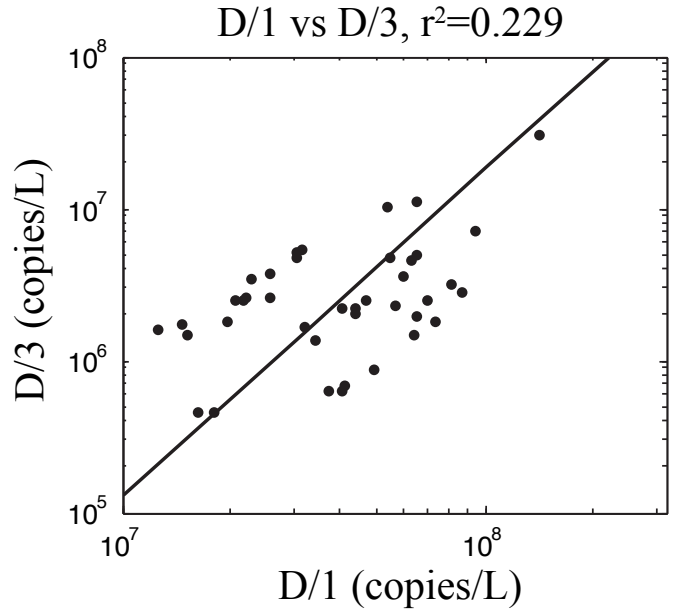

b)

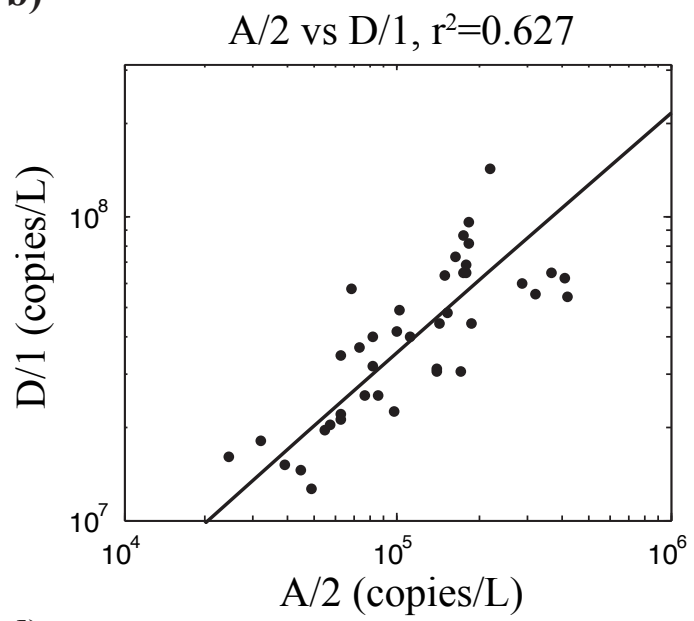

d)

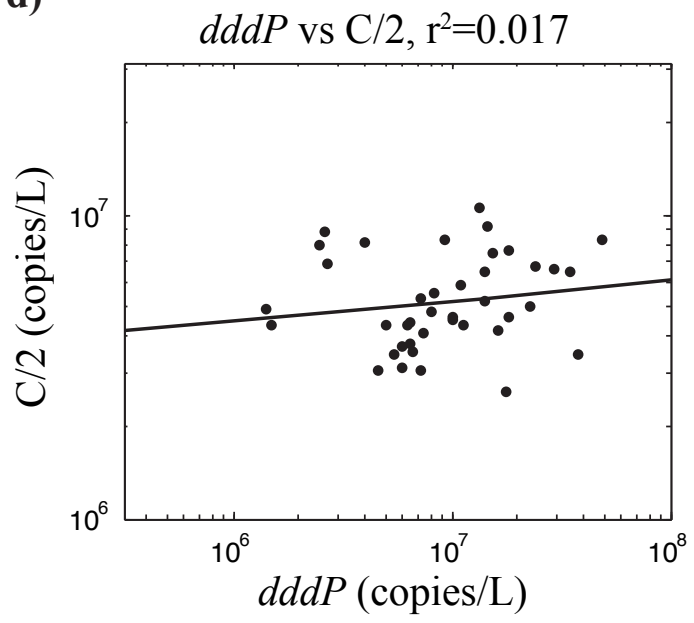

f)

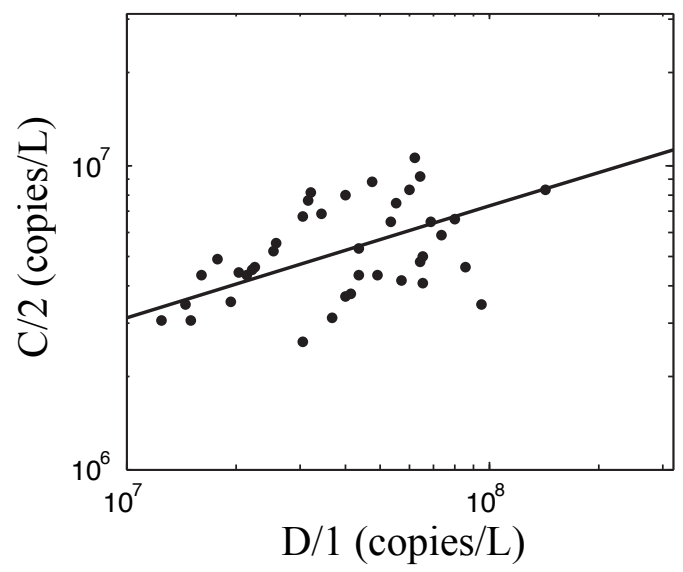

Figure 5.4: The relationship between DMSP degrading genes at BATS. The relationship between dmdA subclades are plotted in panels a), b), e) and f). The relationship between dddP and dmdA subclades $\mathrm{A} / 1$ and $\mathrm{C} / 2$ are plotted in panels $\mathrm{c}$ ) and $\mathrm{d}$ ). These regressions show the strong relationship between Group I subclades, A/1, D/3, and dddP, and the lack of correlation between Group I and Group III (subclade C/2). The 1:1 relationship is plotted as a dashed line in panel c). The R2 value for the linear regression is given in each panel title. 

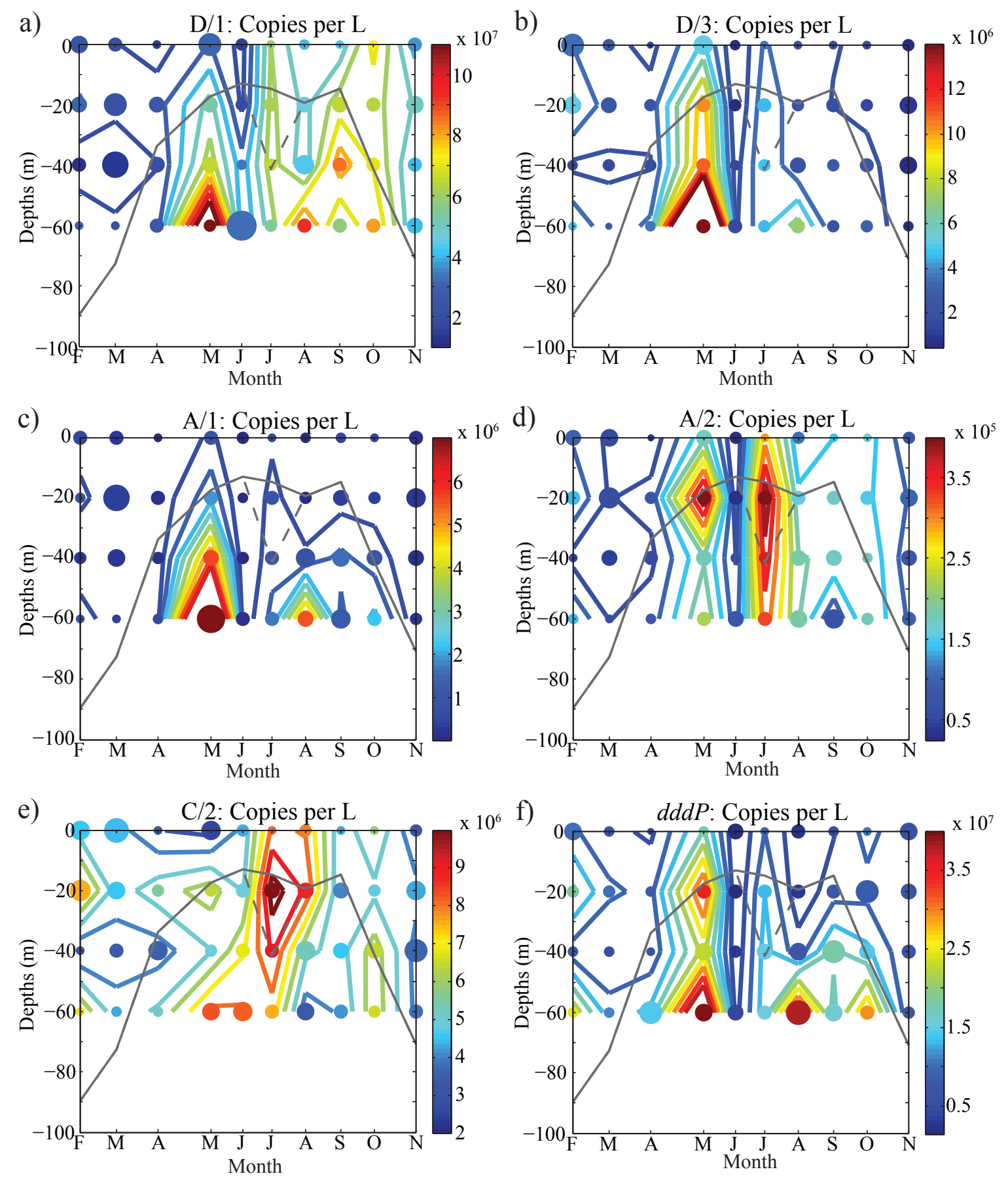

Figure 5.5: The abundance of DMSP degrading genes at BATS. Panels a)-e) plot the abundance of $d m d A$ subclades $\mathrm{D} / 1, \mathrm{D} / 3, \mathrm{~A} / 1, \mathrm{~A} / 2$, and $\mathrm{C} / 2$ in copies per liter of seawater filtered. Panel $\mathrm{f}$ ) plots the abundance of $d d d P$ in copies per liter of seawater filtered. The symbol color corresponds to the number of gene copies per liter and the symbol size is related to the inverse of the coefficient of variation of the measurement such that larger symbols indicate measurements with small error. The mixed layer depths are plotted in gray and the dashed line shows the remnant mixed layer from Hurricane Bertha. 
a) D/1 expression: Copies per L

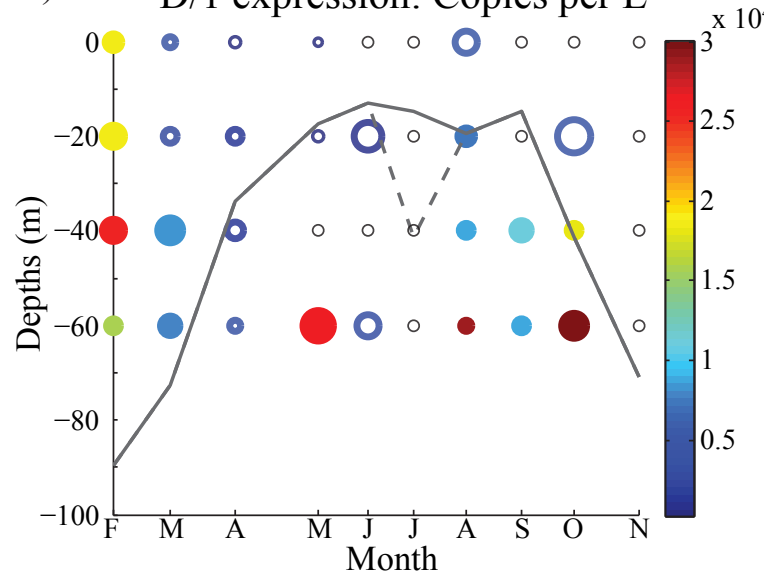

c)

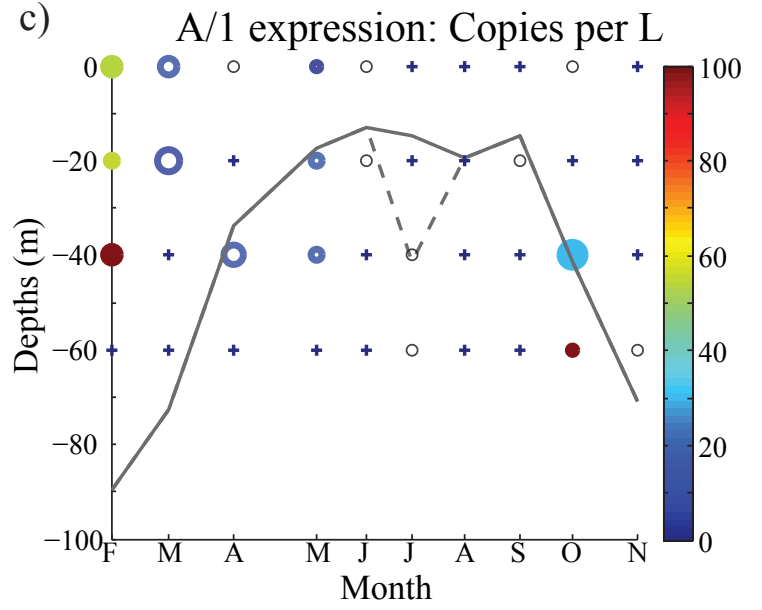

b) D/3 expression: Copies per L

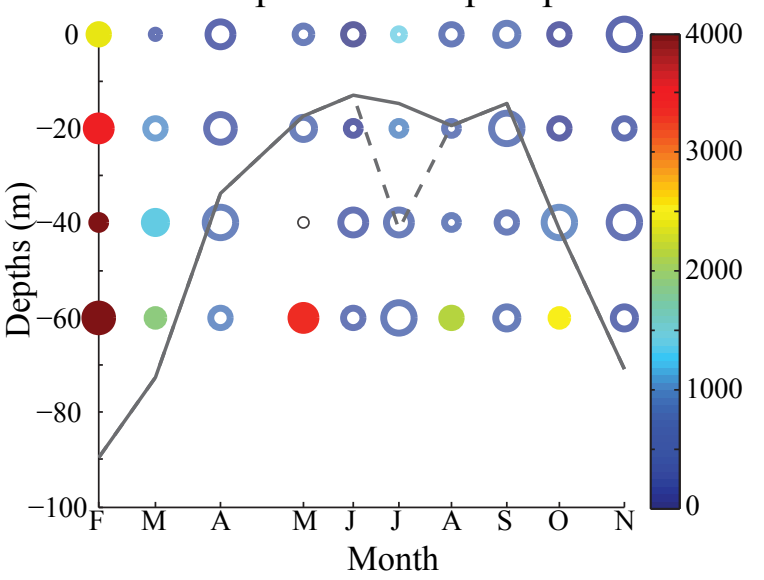

d)

$d d d P \underset{0}{\exp } \underset{0}{\operatorname{expsion}}$

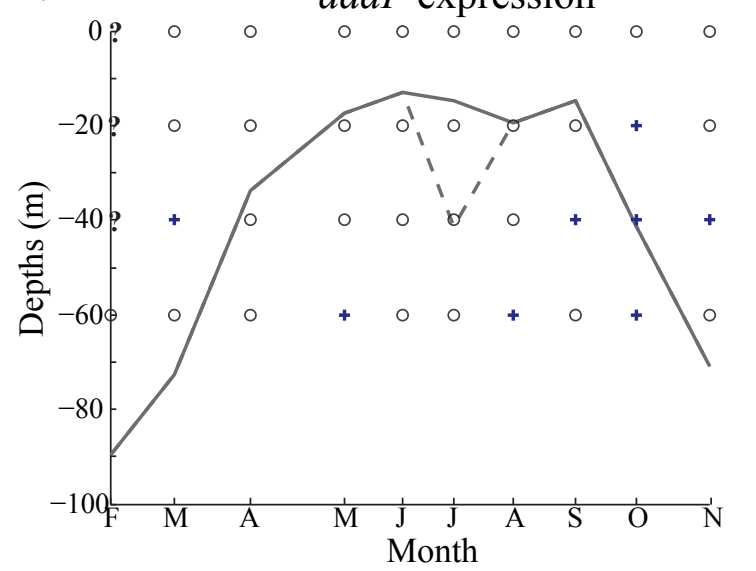

Figure 5.6: The expression of DMSP degrading genes at BATS. The expression of $d m d A$ subclades $\mathrm{D} / 1, \mathrm{D} / 3$, and $\mathrm{A} / 1$ and $d d d P$ in copies per liter of seawater filtered are plotted in panels a)-d), respectively. The symbol color corresponds to the number of expressed gene copies per liter and the symbol size is related to the inverse of the coefficient of variation of the measurement such that larger symbols indicate measurements with small error. Samples marked as "plus expression" are denoted by + symbols and samples marked as "possible expression" are denoted by the ?s. Open circles represent samples without significant expression and black open circles denote samples with no expression. The mixed layer depths are plotted in gray and the dashed line shows the remnant mixed layer from Hurricane Bertha. 
a)

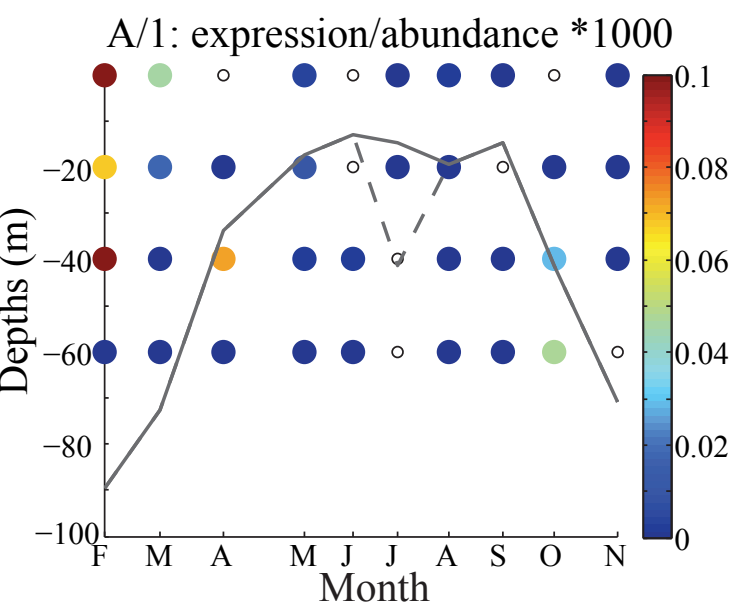

b)

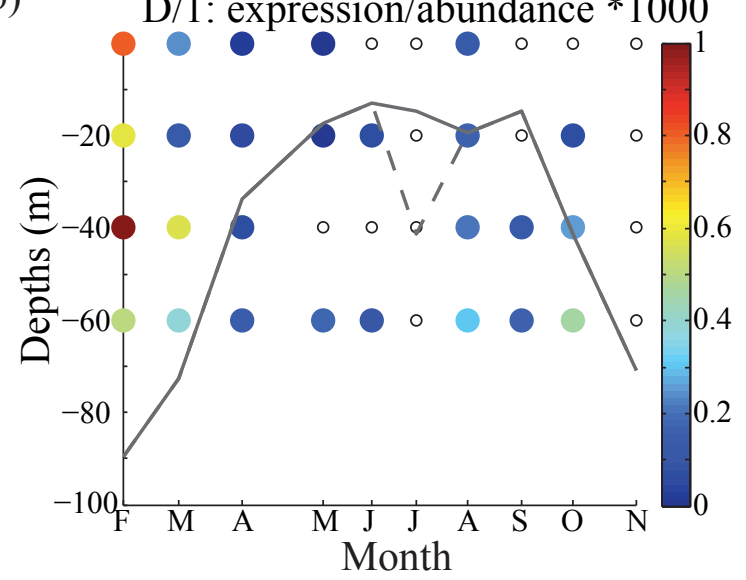

c)
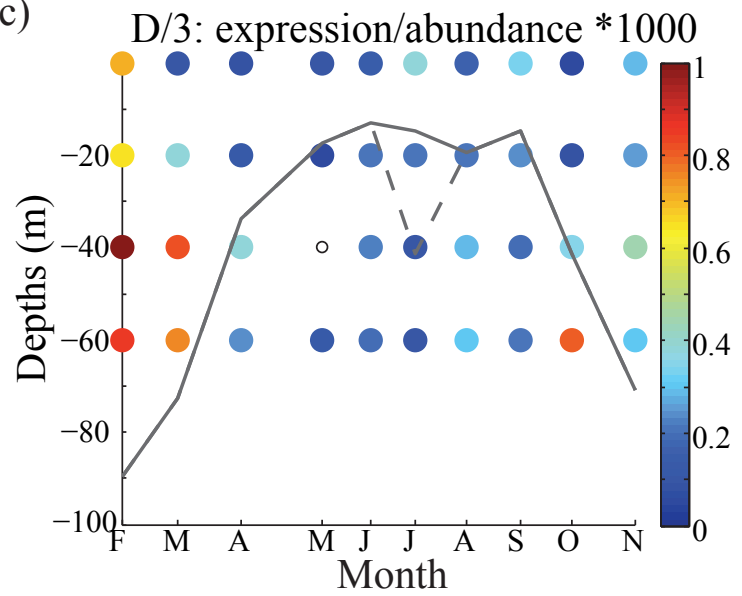

Figure 5.7: Fraction of expressed genes. The fraction of expressed genes (expression/abundance) * 1000 is presented for the $d m d A$ subclades $\mathrm{A} / 1, \mathrm{D} / 1$, and $\mathrm{D} / 3$. The symbol color corresponds to the fraction of genes expressed. Open circles represent samples with no detectable expression. 

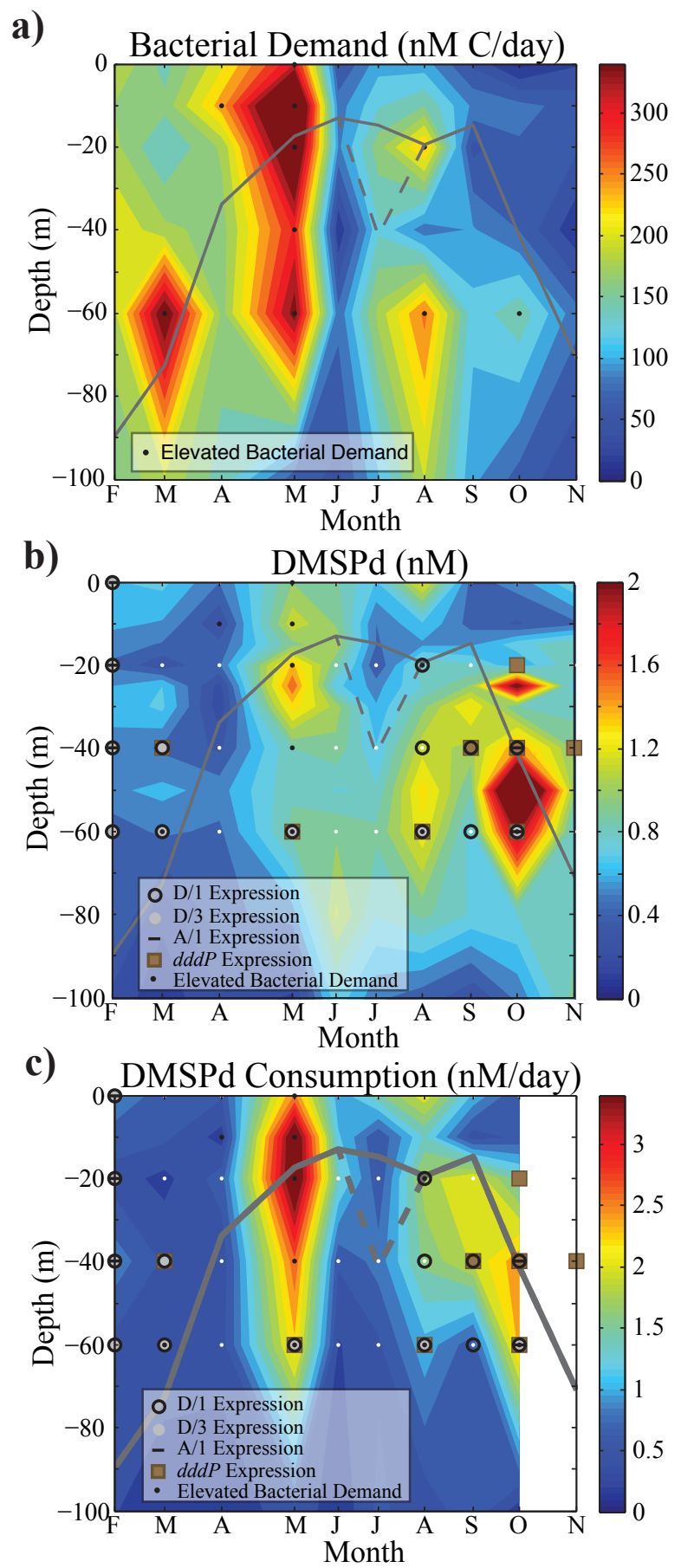

Figure 5.8: Relationship of DMSP degradation gene expression to DMSP and bacterial dynamics. Panel a) plots the bacterial carbon demand in $\mathrm{nM} \mathrm{C}$ /day as measured by $\mathrm{H} 3-$ leucine incorporation. The small solid black circles in all three panels denote regions of elevated bacterial carbon demand. The expression of DMSP degrading genes is overlain on top of DMSPd concentrations (nM) and DMSPd consumption (nM/day) in panels b) and c). The open black circles show D/1 expression, the gray circles denote D/3 expression, the dashed lines denote $\mathrm{A} / 1$ expression and the brown squares denote $d d d P$ expression. The mixed layer depths are plotted in gray and the dashed line shows the remnant mixed layer from Hurricane Bertha. 

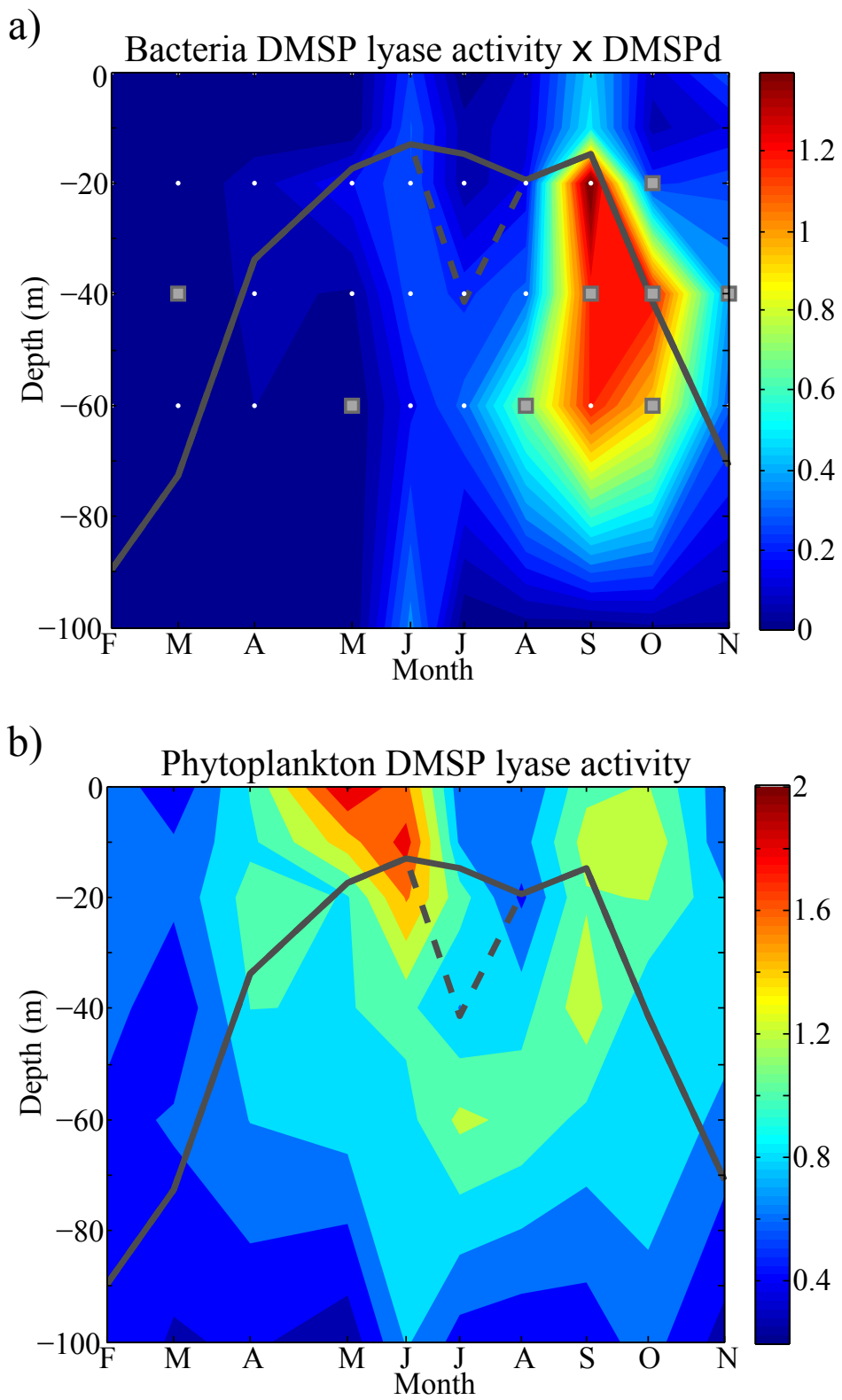

Figure 5.9: Bacterial and Phytoplankton DMSP lyase potential enzyme activity. Panel a) plots bacterial DMS production estimated from bacterial DMSP lyase activity and dissolved DMSPd concentrations. The gene expression sample locations are shown as white dots and the locations with $d d d P$ expression are denoted with gray squares. Panel b) plots the estimated phytoplankton DMS production as determined by the phytoplankton DMSP lyase potential enzyme activity. The mixed layer depths are plotted in gray and the dashed line shows the remnant mixed layer from Hurricane Bertha. 


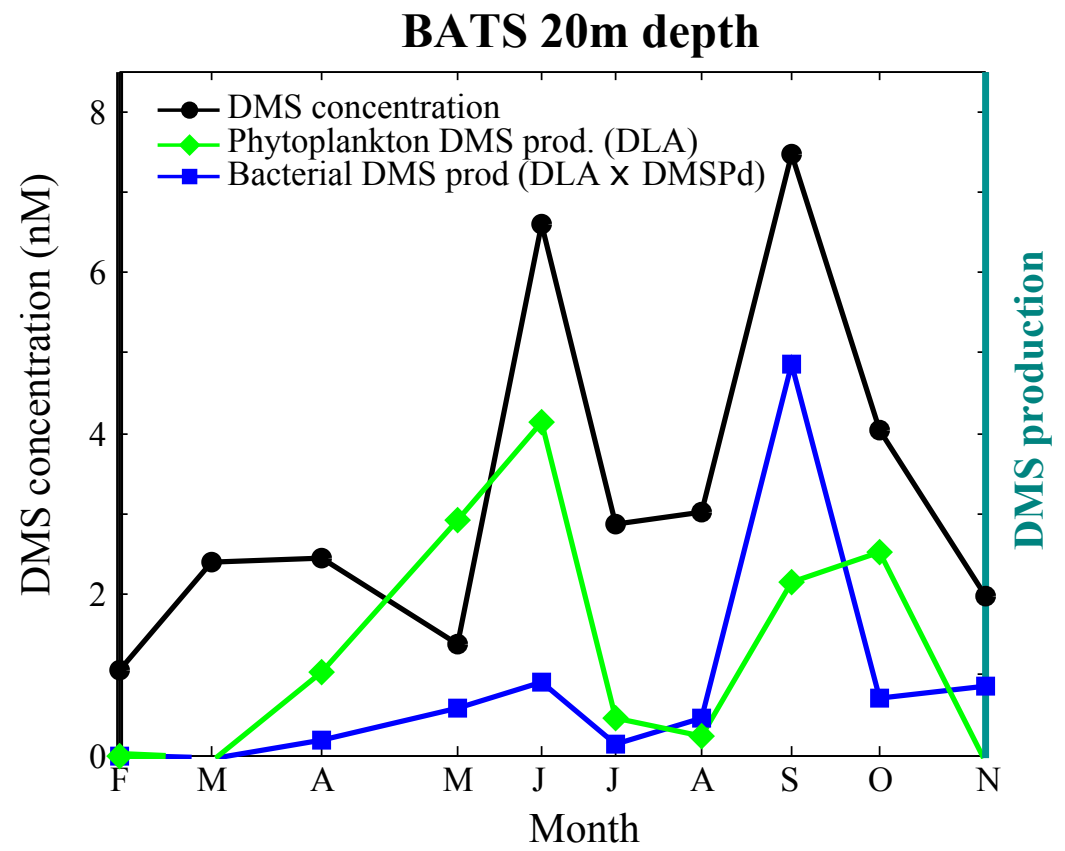

Figure 5.10: DMS production at $20 \mathrm{~m}$ for February-November 2008. DMS concentration (nM) is plotted in black and phytoplankton and bacterial DMS production are plotted in green and blue, respectively. The peaks in DMS concentration correlate with the peaks in bacterial and phytoplankton DMS production, as determined by the potential enzyme assay. It is important to note that the relative contributions of phytoplankton and bacteria to water column DMS concentrations cannot be determined from this analysis. 


\section{Chapter 6:}

\section{Conclusions}

\subsection{SUMMARY OF FINDINGS}

Anthropogenic activity is rapidly and drastically changing the global climate through the emission of carbon dioxide. These changes will have far reaching impacts on

global ecosystems, including ocean ecosystems. However, the response of biogeochemical cycling in the ocean to large scale climate forcing remains poorly determined. In order to constrain the response of the ocean systems to anthropogenic induced changes, it is necessary to understand the dominant mechanisms driving biogeochemical cycling in the oceans. This thesis provides insights into these mechanisms for two critical biogeochemical cycles, the carbon and the sulfur cycles. We specifically focus on anthropogenic carbon storage and dimethylsulfide (DMS) production. 
Chapters 2 and 3 use numerical models to investigate natural variability in the ocean carbon system and determine the impact of this variability on the detection and attribution of anthropogenic carbon (Chapter 2 and 3) and the storage of anthropogenic carbon in the North Atlantic (Chapter 3). Chapters 4 and 5 use field and laboratory techniques to deconvolve the primary mechanisms responsible for seasonal variability in dimethylsulfoniopropionate (DMSP) degradation and DMS production in the oligotrophic North Atlantic (Sargasso Sea). Both the carbon and sulfur studies in this thesis demonstrate the significance of physical changes, specifically vertical mixing, on the biogeochemical cycling of these elements. The storage of anthropogenic carbon in North Atlantic mode waters is heavily influenced by water mass transformation during wintertime mixing events (Chapter 3). Similarly, vertical mixing and UV radiative stress appear to be the dominant mechanisms behind seasonal variability in DMS production in the Sargasso Sea (Chapter 4).

This thesis demonstrates the importance of model-observation synergy; observations are needed to validate and improve numerical models (e.g. Chapter 3 and Chapter 5), and models are able to provide context and a mechanistic explanation for observations (Chapter 2 and Chapter 3). For the carbon cycle, a global coupled carbon model is able to identify regions where empirical methods applied to hydrographic measurements may not fully account for natural variability in the carbon system (Chapter 2). Namely, these methods appear to bias estimates of anthropogenic carbon in water mass formation regions by incorrectly attributing changes in dissolved oxygen concentrations to biologic activity instead of air-sea disequilibrium. Similarly, an 
analysis of interannual variability in anthropogenic carbon inventories in the North Atlantic is able to provide context for hydrographic observations, which are often biased by sampling schemes that can alias natural variability into estimates of long term trends due to short-duration or sparse observational data sets (Chapter 3). For the sulfur cycle, field observations demonstrate both the importance and dynamics of bacterial communities responsible for DMSP degradation in oligotrophic surface waters (Chapter 5) suggesting that modifications may need to be made to current upper ocean sulfur cycle numerical models. Specifically, the current static parameterizations of bacterial DMSP cycling should be replaced with a dynamic bacterial component which includes DMSP degradation and DMS production.

\subsection{SIGNIFICANCE}

Future climate change is predicted to impact ocean ecosystems through increased sea surface temperatures, increased vertical stratification, variable wind forcing, and decreased nutrient concentrations [e.g. Boyd and Doney, 2002; Sarmiento et al., 2004]. The driving mechanisms in carbon and sulfur cycling dynamics identified in this thesis allow for speculation as to the potential impact of climate induced changes on these two biogeochemical cycles.

\subsubsection{The Carbon Cycle}

Chapter 2 identifies several regions where empirical methods for estimating anthropogenic carbon $\left(C_{\text {anthro }}\right)$ concentrations from hydrographic observations may 
introduce errors. Secular changes in ocean properties will exacerbate the difficulties of detection. Specifically, most empirical approaches for estimating $C_{\text {anthro }}$ rely on the assumption that baseline correlations between hydrographic properties- e.g. temperature, salinity, $\mathrm{O}_{2}$, and nutrients- remain constant with time. This assumption will most likely break down in an evolving climate where climate feedbacks, such as secular warming and changes in transport, ventilation, and remineralization, will have non-linear effects on hydrographic properties. This is particularly true for the Multiple Linear Regression (MLR) analysis that assumes a stationary ocean where shifts in water properties at a specific location, resulting from changes in circulation and remineralization, follow a statistically derived linear relationship. The MLR method is not designed to account for long-term trends, such as the secular warming of the oceans, which will non-linearly shift the correlation between DIC and temperature, salinity and nutrients. For example, an increase in ocean temperature with constant DIC will be interpreted by the MLR technique as an increased uptake of anthropogenic $\mathrm{CO}_{2}$, assuming that DIC and temperature are negatively related in the MLR at time 0 . This results in a discrepancy between the empirically based estimates of $\Delta C_{\text {anthro }}$ the change in DIC relative to a baseline correlation- and the change in DIC inventory due to the net uptake of $\mathrm{CO}_{2}$ from the atmosphere. In the thermal warming case described above, there is an increase in DIC relative to the expected quantity as determined from hydrographic correlations. However, no additional $\mathrm{CO}_{2}$ is drawn out of the atmosphere. The difference in these two interpretations has significant implications when determining the magnitude of the net oceanic sink for atmospheric $\mathrm{CO}_{2}$ and when projecting the trajectory of atmospheric $\mathrm{CO}_{2}$ 
concentrations. While the MLR technique is particularly susceptible to changes in baseline correlations, all empirical based methods for estimating $C_{\text {anthro }}$ will be affected to varying degrees by secular trends.

Chapter 3 investigates the response of anthropogenic carbon storage to interannual variability driven by the North Atlantic Oscillation, the dominant climate mode in the North Atlantic. As is discussed in section 3.7, a future increase in the frequency of positive NAO years, as is suggested by IPCC models [Meehl et al., 2007], may impact the magnitude of the North Atlantic carbon sink. Specifically, positive NAO years are concurrent with increased wintertime mixing resulting in increased mode water formation in both the subtropical and subpolar gyres. Water mass transformation during mode water formation results in the transfer of surface anthropogenic $\mathrm{CO}_{2}$ onto the deeper mode water surfaces. Therefore, increased mode water formation yields higher subsurface $C_{\text {anthro }}$ inventories. However, other climate feedbacks may negatively impact $C_{\text {anthro }}$ storage. Specifically, water mass formation may decrease due to increased stratification caused by surface water warming and/or subpolar freshening.

Throughout the global oceans, mode and intermediate water formation is the primary mechanism for sequestering $C_{\text {anthro }}$ at intermediate depths in the ocean [Sabine et al., 2004]. Therefore, changes in the anthropogenic carbon burden of these waters could significantly impact the global ocean carbon sink. The mechanisms driving interannual variability in North Atlantic mode water $C_{\text {anthro }}$ inventories (Chapter 3) can provide insight into carbon storage variability for other mode waters. Similar to the Eighteen Degree mode water (EDW) in the North Atlantic, a subtropical mode water (STMW) is 
formed in the North Pacific south of the Kuroshio Extension during the wintertime due to air-sea heat flux [Hanawa, 1987]. Pacific STMW properties appear to be driven by an intensification of the westerlies caused by a strong Aleutian low [Yasuda et al., 2002]. This thesis and Joyce et al. [2000] conclude that the thickness of EDW is related to the position of the Gulf Stream. Similarly, Qiu and Chen [2006] find that the thickness of North Pacific STMW is related to changes in the state of the Kuroshio Extension. The similarity between North Atlantic and North Pacific mode water formation mechanisms suggests that the STMW anthropogenic carbon inventory dynamics discussed in Chapter 3 may be relevant for North Pacific mode waters. Specifically, changes in the Kuroshio Extension system driven by climate variability (e.g. intensification of the westerlies) may impact the uptake and storage of anthropogenic carbon in the North Pacific subtropical gyre.

The southern ocean accounts for a large fraction of global $C_{\text {anthro }}$ uptake and storage through the formation of mode, intermediate and deep waters. These waters form equatorward of the Antarctic Circumpolar Current (ACC) between $\sim 40-55^{\circ} \mathrm{S}$ due to wintertime convection and air-sea heat flux [McCartney, 1977]. Based on hydrographic observations from the Drake Passage, Garbato et al. [2009] conclude that significant interannual variability in subantarctic mode water properties is driven by changes in winter air-sea turbulent heat fluxes. They further conclude that these physical fluctuations correlate to shifts in the ENSO index and to a lesser extent the Southern Annular Mode (SAM), the two primary climate modes in the southern ocean. Preliminary modeling work similar to the study presented in Chapter 3 indicates that 
anthropogenic carbon inventories north of the ACC increase in response to a shift in the SAM [N. Levine, unpublished]. If confirmed, these findings would support the conclusion of Chapter 3 that increased wind stress (in this case driven by SAM) increases mode water formation yielding high anthropogenic carbon accumulation. However, the

implication of increased mode water $C_{\text {anthro }}$ on the magnitude of the Southern Ocean carbon sink is unclear. Levine et al. [unpublished] find that a shift in the SAM decreases the accumulation of anthropogenic carbon poleward of the ACC such that SAM has a very small net effect on the southern ocean. These findings are consistent with Lovenduski et al. [2008] who conclude that changes in wind stress do not impact the net uptake of anthropogenic carbon by the southern ocean ( The similarity between these results is to be expected as Lovenduski and Levine use the same ocean model). Changes in anthropogenic $\mathrm{CO}_{2}$ uptake rates are further obscured by large changes in the natural carbon that have resulted in a decrease in the Southern Ocean carbon sink [Lovenduski et al., 2008]. Further work is needed to investigate the mechanisms driving interannual variability in anthropogenic carbon accumulation in the Southern ocean and how this impacts the global ocean carbon sink.

\subsubsection{The Sulfur Cycle}

Anthropogenically induced changes to the upper ocean ecosystem have the potential to significantly impact DMS and DMSP cycling. Specifically, increased stratification caused by warming surface waters will increase the radiative dose 
experienced by surface planktonic communities. Changes in the oligotrophic, upper ocean sulfur cycle are highly correlated with changes in mixed layer depth and UV radiation stress [Chapter 5, Slezak et al., 2007; Toole et al., 2008; Toole et al., 2003; Vallina and Simo, 2007; Vila-Costa et al., 2007]. Namely, phytoplankton DMSP concentrations and DMSP lyase activity peaks in the spring and early summer concurrent with the shoaling of the mixed layer. Phytoplankton DMSP lyase enzyme activity remains elevated in surface waters throughout the summer when surface waters are highly stratified and the UV radiation dose is high. Bacterial DMSPd degradation via the demethylation pathway may be light sensitive (Chapter 5), and bacterial DMS consumption has been shown to be inhibited by UV radiation [Slezak et al., 2001; Toole et al., 2006]. Therefore, in response to climate induced increases in UV stress, phytoplankton DMS production may increase and bacterial DMS consumption may decrease. In addition, preliminary findings suggest that the bacterial DMSP cleavage pathway may be favored over the DMSP demethylation pathway under high UV radiation. If confirmed, this would indicate that future increases in ocean stratification might result in increased bacterial DMS production and decreased bacterial DMSP demethylation.

This thesis suggest that, in addition to physical and chemical conditions, bacterial community composition is an important factor in upper ocean sulfur cycling. An analysis of DMSP degrading genes shows significant seasonal variability in the presence of DMSP degraders in the Sargasso Sea. The increase in both $d m d A$ (DMSP demethylation gene) and $d d d P$ (DMSP cleavage gene) in the late summer and early fall 
corresponds to an increase in bacterial DMSP degradation. Climate driven changes in upper ocean physics may alter the seasonal succession in bacterial community thereby impacting DMSP and DMS cycling in surface waters. Specifically, increased stratification and UV stress may result in a longer "summer" season that could in turn impact the bacterial community and bacterial sulfur cycling.

Our findings suggest that the response of the upper ocean sulfur cycle to anthropogenic climate change may result in a negative feedback loop. Namely, increased surface water stratification will result in increased UV radiative stress, which will increase DMS production. Greater DMS production has the potential to increase DMS ventilation to the atmosphere, which in turn yields increased sulfur aerosols abundance and increased cloud coverage. Greater scattering and reflection of incoming solar radiation will decrease the global heat balance and help offset the anthropogenically driven temperature increase. However, other climate induced changes, such as shifts in phytoplankton community composition, increased photolysis, or increased ventilation, may act to offset some of these changes. The magnitude of the DMS negative feedback loop remains to be determined. However, the mechanisms elucidated in this thesis are a step towards improving numerical models of the upper ocean sulfur cycle so as to improve future predictions of DMS production. 


\subsection{THE WAY FORWARD}

\subsubsection{The detection of anthropogenic carbon in the oceans}

Chapters 2 and 3 focus on issues of detection and attribution of anthropogenic carbon. Specifically, we discuss the impact of interannual and interdecadal variability on the accurate detection of the ocean sink from hydrographic observations. Chapter 2 suggests the need for high frequency observations in regions of water mass formation where empirical methods may bias estimates of anthropogenic carbon. Chapter 3 shows that the time-scales of sampling campaigns can impact the estimated uptake of anthropogenic carbon by aliasing interannual variability in carbon storage into estimates of $C_{\text {anthro }}$ uptake. The results of these modeling studies call into question our ability to accurately detect the underlying long term trends in the upper ocean carbon sink over the significant shorter-term variability. Namely, the compounded errors of empirical methods and short sampling timescales make these longer term trends very difficult to accurately detect from the observations. However, we believe this hurdle can be overcome using model-observation synergy. Specifically, these trends can be studied using observations to validate model output and model output to provide a picture of the ocean carbon sink for longer time-scales, and with higher resolution and greater spatial coverage.

Significant resources have been devoted to quantifying surface pCO2 and air-sea $\mathrm{CO}_{2}$ flux. However, the modeling analysis presented in Chapter 3 suggests that local airsea $\mathrm{CO}_{2}$ fluxes are not responsible for the majority of $C_{\text {anthro }}$ inventory changes in the 
ocean interior. Therefore, local measurements of air-sea $\mathrm{CO}_{2}$ flux may provide limited information of anthropogenic carbon storage for that region. We suggest that future studies may be better served to focus on quantifying rates of water mass transformation, which act to transfer high $C_{\text {anthro }}$ surface waters onto deeper isopycnal surfaces. In addition, an increased focus on the measurement of depth profiles, as opposed to surface measurements, will be necessary to accurately quantify the ocean carbon sink. Finally,

monitoring changes in surface $C_{\text {anthro }}$ transport into water mass formation regions will be important for improving our understanding of how the ocean carbon sink may change in response to future climate changes.

\subsubsection{Testing our hypothesis of the upper ocean sulfur cycle}

The work presented in this thesis is only a first step in unraveling the complex processes responsible for DMSP degradation and DMS production. Significant laboratory, field and modeling work are needed to test and refine the hypotheses presented in Chapter 5. Here we suggest five potential avenues for further study.

In this thesis, we took a three pronged approach to understanding bacterial DMS(P) cycling; first analyzing the presence of DMSP degrading genes, next analyzing the expression of DMSP degrading genes, and finally determining the enzyme activity of DMSP degrading enzymes. Proteomics has the potential to bridge the gap between gene expression (step 2) and enzyme activity (step 3) by quantifying the amount of protein present in a sample. In addition, proteomics may help provide an improved 
understanding of the potential enzyme assays. As discussed in Chapter 5, we were unable to determine if the bacterial DMSP lyase potential enzyme assay (DLA) quantifies the activity of all types of bacterial DMSP cleaving enzymes. Proteomics could help answer this question.

While a nice relationship was observed between potential enzyme activity and DMS concentrations at $20 \mathrm{~m}$, the limitations of the potential enzyme assay are substantial (section 4.5). Significant work is needed to understand how DLA rate measurements relate to in situ cycling. Specifically, additional comparisons are needed between the potential enzyme assay and the ${ }^{35} \mathrm{~S}$ radioisotope measurements. In particular, once the issues of potential DMDS inhibition on the ${ }^{35} \mathrm{~S}$-DMS yield assay are resolved, this assay can be directly compared to the bacterial DLA rate measurements to help to understand the relationship between DLA rate and biogeochemical rate.

The possibility of a seasonal succession in DMS production is one of the primary hypotheses proposed by this thesis. Field studies quantifying both bacterial and phytoplankton DMS production during different seasons would help to further refine this hypothesis and address whether the pattern observed at BATS in 2008 was truly a seasonal succession or whether it was a product of changes in the physical and chemical properties of the water column. These studies could take the form of either additional time-series work or as discrete cruises (e.g. a cruise in June and a cruise in September to the same oceanographic region).

Bacterial DMS consumption is important in upper ocean sulfur cycling. Currently, this pathways is measured using the ${ }^{35} \mathrm{~S}$ method of Kiene and Linn [2000]. To 
our knowledge, a DMS consumption gene has not yet been published. However, there are currently several labs working to identify this gene [M.A. Moran personal comm.]. Once this gene becomes available, quantifying the abundance and expression of this gene in combination with the demethylation $(d m d A)$ and the DMS producing $(d d d P)$ genes will provide a more complete picture of the bacterial community responsible for DMS(P) cycling. In addition, the expression of the DMS degradation gene could be directly compared to the biogeochemical rate; something we were not able to do with the $d m d A$ and $d d d P$ genes.

Finally, the incorporation of some of the main findings from this thesis into a numerical model is an important next step. Chapters 2 and 3 stress the importance of model-observation synergy in carbon cycle observations. Similarly, numerical models provide an ideal platform for testing some of the sulfur cycling hypotheses proposed in Chapter 5 and some of the potential feedbacks discussed in section 6.2.2. Section 5.5 explores how the findings of the gene expression and potential enzyme analyses may be incorporated into a global numerical model. Namely parameterizing bacterial DMSP degradation based on seasonal variations in DMSPd concentrations (related to DMSPp concentrations), bacterial carbon demand, and UV radiation stress. And defining phytoplankton DMS production in terms of UV radiation dose.

We still lack an understanding of the relative importance of the DMSP demethylation versus the DMSP cleavage pathways. Specifically, what fraction of the dissolved DMSP pool is converted to DMS and how this varies seasonally. However, the variations in gene expression and potential enzyme activity measured during the ten- 
month time-series have provided insight into the chemical and physical properties controlling bacterial DMSP degradation. These hypotheses, such as UV inhibition of the demethylation pathway or the anti-oxidant function of the cleavage pathway, can be further tested by incorporating these mechanisms into a numerical model. This provides insight into the sensitivity of the sulfur cycle to these processes and can help guide further field and laboratory study. 


\subsection{REFERENCES}

Boyd, P. W., and S. C. Doney (2002), Modelling regional responses by marine pelagic ecosystems to global climate change, Geophys. Res. Lett., 29(16).

Garabato, A. C. N., L. Jullion, D. P. Stevens, K. J. Heywood, and B. A. King (2009), Variability of Subantarctic Mode Water and Antarctic Intermediate Water in the Drake Passage during the Late-Twentieth and Early-Twenty-First Centuries, Journal of Climate, 22(13), 3661-3688.

Hanawa, K. (1987), Interannual variations in the winter-time outcrop area of Subtropical Mode Water in the western North Pacific Ocean, Atmosphere-Ocean, 25, 358-374.

Joyce, T. M., C. Deser, and M. A. Spall (2000), The relation between decadal variability of subtropical mode water and the North Atlantic Oscillation, Journal of Climate, 13(14), 2550-2569.

Kiene, R. P., and L. J. Linn (2000), The fate of dissolved dimethylsulfoniopropionate (DMSP) in seawater: Tracer studies using S-35-DMSP, Geochimica Et Cosmochimica Acta, 64(16), 2797-2810.

Lovenduski, N. S., N. Gruber, and S. C. Doney (2008), Toward a mechanistic understanding of the decadal trends in the Southern Ocean carbon sink, Global Biogeochemical Cycles, 22(3).

McCartney, M. S. (Ed.) (1977), Subantarctic Mode Water, 103-119 pp., Pergamon Press, Oxford, U.K.

Meehl, G. A., et al. (2007), Global Climate Projections. In: Climate Change 2007: The Physical Scince Basis. Contribution of Working Group I to the Fourth Assesment Report of the Intergovernmental Panel on Climate Change., in Climate Change 2007: The Physical Scince Basis. Contribution of Working Group I to the Fourth Assesment Report of the Intergovernmental Panel on Climate Change, edited by S. Solomon, D. Qin, M. Manning, Z. Chen, M. Marquiz, K. B. Averyt, M. Tignor and H. L. Miller, Cambridge University Press, Cambridge, United Kingdom and New York, NY, USA.

Qiu, B., and S. M. Chen (2006), Decadal variability in the formation of the North Pacific Subtropical Mode Water: Oceanic versus atmospheric control, Journal of Physical Oceanography, 36(7), 1365-1380. 
Sabine, C. L., et al. (2004), The oceanic sink for anthropogenic $\mathrm{CO}_{2}$, Science, 305(5682), 367-371.

Sarmiento, J. L., et al. (2004), Response of ocean ecosystems to climate warming, Global Biogeochemical Cycles, 18(3).

Slezak, D., A. Brugger, and G. J. Herndl (2001), Impact of solar radiation on the biological removal of dimethylsulfoniopropionate and dimethylsulfide in marine surface waters, Aquatic Microbial Ecology, 25(1), 87-97.

Slezak, D., R. P. Kiene, D. A. Toole, R. Simo, and D. J. Kieber (2007), Effects of solar radiation on the fate of dissolved DMSP and conversion to DMS in seawater, Aquatic Sciences, 69(3), 377-393.

Toole, D. A., D. A. Siegel, and S. C. Doney (2008), A light-driven, one-dimensional dimethylsulfide biogeochemical cycling model for the Sargasso Sea, Journal of Geophysical Research-Biogeosciences, 113(G2).

Toole, D. A., D. J. Kieber, R. P. Kiene, D. A. Siegel, and N. B. Nelson (2003), Photolysis and the dimethylsulfide (DMS) summer paradox in the Sargasso Sea, Limnology and Oceanography, 48(3), 1088-1100.

Toole, D. A., D. Slezak, R. P. Kiene, D. J. Kieber, and D. A. Siegel (2006), Effects of solar radiation on dimethylsulfide cycling in the western Atlantic Ocean, Deep-Sea Research Part I-Oceanographic Research Papers, 53(1), 136-153.

Vallina, S. M., and R. Simo (2007), Strong relationship between DMS and the solar radiation dose over the global surface ocean, Science, 315, 506-508.

Vila-Costa, M., J. Pinhassi, C. Alonso, J. Pernthaler, and R. Simo (2007), An annual cycle of dimethylsulfoniopropionate-sulfur and leucine assimilating bacterioplankton in the coastal NW Mediterranean, Environmental Microbiology, 9(10), 2451-2463.

Yasuda, I., S. Kouketsu, K. Katsumata, M. Ohiwa, Y. Kawasaki, and A. Kusaka (2002), Influence of Okhotsk Sea Intermediate Water on the Oyashio and North Pacific Intermediate Water, Journal of Geophysical Research-Oceans, 107(C12). 


\section{Appendix A}
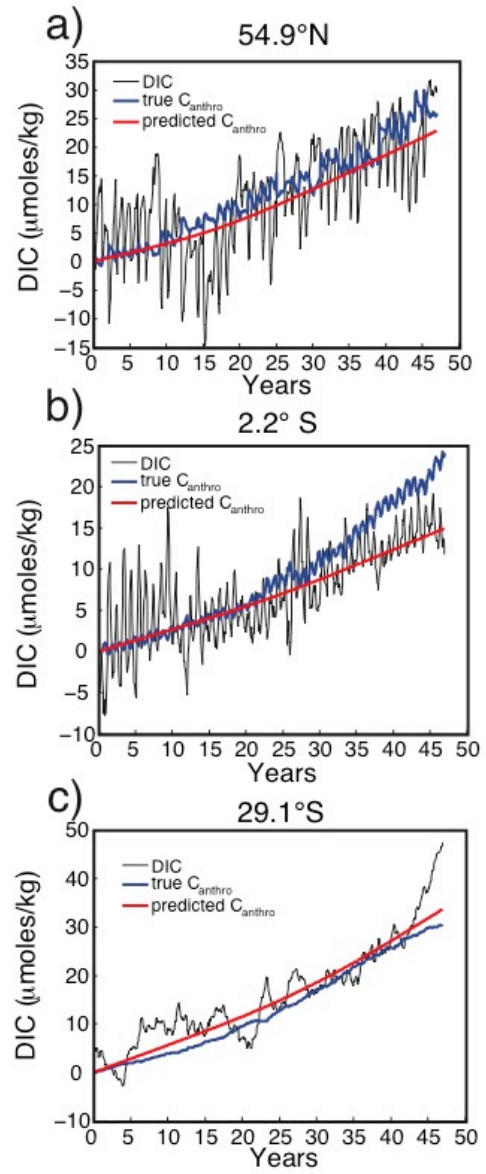

Figure 1: Time-series of historical (1958-2004) ocean-only model output along the A16 transect at 190 $\mathrm{m}$ and (a) $54.9^{\circ} \mathrm{N}$, (b) $2.2^{\circ} \mathrm{S}$, and (c) $29.1^{\circ} \mathrm{S}$. The transient run DIC concentrations, normalized to year zero, are shown in black. The true $C_{\text {anthro }}$ estimates, calculated as the difference between a control run and a transient run with identical surface forcing and nearly identical physical circulation, are shown in blue. The low-pass filter estimates of $C_{\text {anthro }}$ calculated using a spline fit to the transient run are shown in red. 


\section{Appendix B}

a)

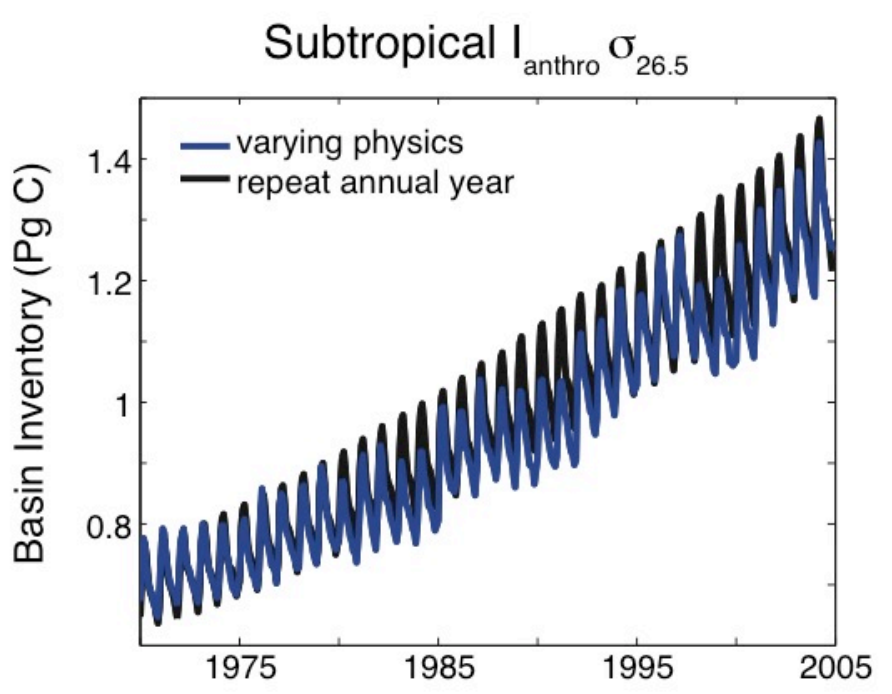

b)

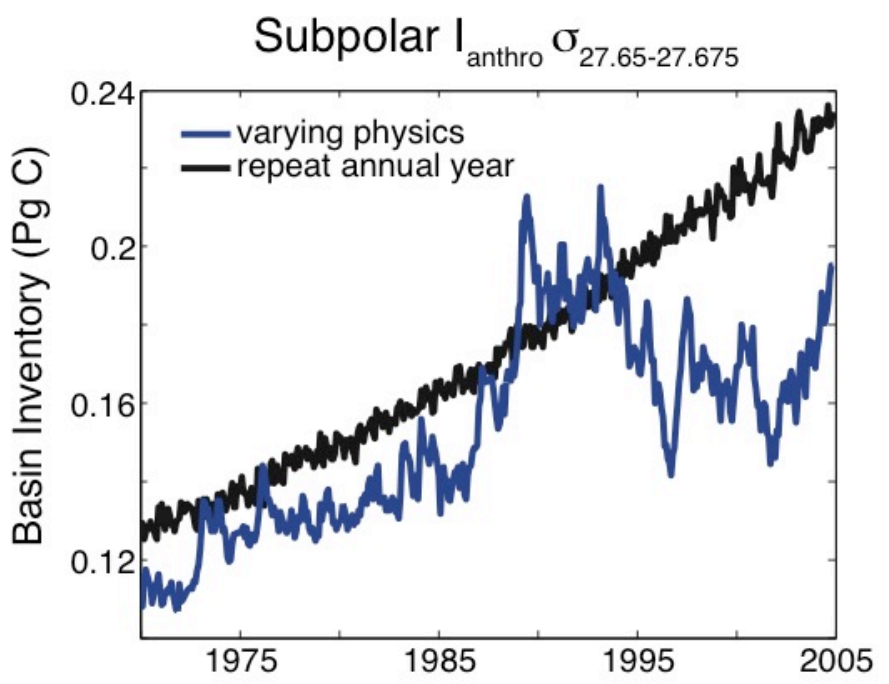

Appendix B: Impact of model bias on anthropogenic carbon inventories $\left(I_{\text {anthro }}\right)$. Panel a) shows the inventory for the subtropical $\sigma_{26.5}$ isopycnal band for which the mean state of the Variable Physics and Repeat Annual Year simulations appears to be equivalent. Panel b) shows the inventory for the subpolar $\sigma_{27.65-27.675}$ isopycnal band for which there appears to be a negative model bias. Specifically that the mean $\mathrm{C}_{\text {anthro }}$ uptake rate for the Variabile Physics simulation is less than the mean $\mathrm{C}_{\text {antho }}$ uptake rate for the Repeat Annual Year simulation. The subpolar $\sigma_{27.675-27.7}$ isopycnal band (not shown) similarly shows a positive model bias that is smaller than the $\sigma_{27.65-27.675}$ band. 


\section{Appendix C}

\section{Bacterial DMSP Demethylation Potential Enzyme Activity}

The biochemistry of the DMSP demethylation pathway was elucidated by Howard et al [2006]. They show that the demethylation enzyme requires a co-factor, tetrahydrofolate (THF), and anoxic conditions. Reisch et al. [2008] developed an enzyme assay for quantifying the potential enzyme activity in samples of purified enzyme extracted from lab cultures. Modifying this protocol for environmental samples requires: 1) an alternative lysis method, as the French press method employed by Reisch et al. can not be applied to filter samples, 2) higher sensitivity, as we expect the activity in environmental samples to be significantly lower than that of purified enzymes, and 3) direct quantification of the reaction product (methiolpropionate or methylmercaptopropionate, MMPA) rather than of the altered co-factor (methylatedTHF).

Several lysis methods were tested during the bacterial DLA method development (see description in Chapter 4 section 4.3.2.2.1). These tests conclude that lysing cells using bead-beating plue lysozyme provides maximum lysis while having the smallest effect on enzyme activity, though this effect was still significant for the DMSP cleavage enzyme. Therefore, we chose this lysis method for the DMSP demethylation protocol.

MMPA standards must be synthesized from methyl-methylthiopropionate (Sigma

Aldrich). The current method for MMPA synthesis was developed by R. Kiene (personal 
communication). However, tests showed incomplete conversion from methyl-MMPA to MMPA following this protocol. An alternative method was developed (see Appendix I) which produces near complete conversion of methyl-MMPA to MMPA. Briefly, high concentrations of $\mathrm{NaOH}$ are added to a sample of methyl-MMPA. After a 15 minute incubation at room temperature, the $\mathrm{pH}$ is brought back to $\sim 7$ using hydrochloric acid. This method is significantly quicker and more reliable than the previous method for MMPA synthesis.

The cofactor required by the DMSP demethylation enzyme, tetrahydrofolate (THF), is extremely oxygen, light, and $\mathrm{pH}$ sensitive. As a result, THF degrades rapidly during the assay. This produces two difficulties: 1) if too much of the THF degrades it may limit the conversion of DMSP to MMPA, and 2) the degradation products of THF are numerous and obscure the MMPA peak during high performance liquid chromatograph analysis. The THF available from Sigma Aldrich is only $70 \%$ pure. Therefore, even without degradation during the assay, the THF contains contaminating peaks which obscure MMPA. An alternative source of THF (Schircks Lab) was found which is $95 \%$ pure thereby reducing the contamination found in the Sigma product. In addition, Schircks Lab produces two forms of THF an S,R form and an $\mathrm{S}$ form. According to the lab, S-THF is the natural form of the compound. Therefore, $95 \%$ pure S-THF was used for the DMSP demethylation assay. The S-THF purchased from Schircks Lab was checked on a Thermo Scientific linear ion-trap mass spectrometer (LTQ-MS) to confirm the mass and structure of the compound. All work involving THF was conducted in an anaerobic glove bag filled with $\mathrm{N}_{2}$ and $\mathrm{H}_{2}$. 
Reisch et al. [2008] uses dithiothretol (DDT) as a reducing agent to keep the assay anoxic thereby preventing the degradation of THF. A literature search showed that titanium citrate is a more effective reducing agent than DDT [Breznak and Costilow, 1994]. In addition, titanium citrate does not contain sulfur and so does not produce interfering peaks when the SBD-F protocol is followed (see description below) and it does not effect bacterial cultures [Breznak and Costilow, 1994] and so should have a minimal effect on the DMSP demethylation enzyme. Therefore, we decided to use titanium citrate as the reducing agent for this protocol. The effectiveness of titanium citrate was confirmed using Resazurin, a redox sensitive die. Titanium citrate was synthesized following the protocol of Smith and Woods [1994] (see Appendix J).

The production of MMPA during the assay was monitored on an Agilent high performance liquid chromatograph (HPLC) using an Agilent Eclipse XDB-C18 column. We use fluorescent derivatization to enhance the MMPA signal. Two different derivatization methods were tested: derivatization to the methanethiol group, and derivatization to the carboxylic group.

Ammonium-7-florobenzo-2-oxa-1,3-diazole-4-sulfonate (SBD-F) was derivatized to the sulfur group in MMPA and mercaptopropionate (MPA) following the attached protocol (Appendix K) modified from Tang et al. [2000] and Zhang et al. [2004]. Both pervious studies add reducing agents before the derivatization step. We found this step to be unnecessary as the assay was already reduced due to the titanium citrate. In fact, the addition of TCEP, the compound used by Zhang et al., reduced the MMPA signal rather than enhanced it. The reaction is also highly $\mathrm{pH}$ sensitive, and so the optimal amount of 
$\mathrm{NaOH}$ needed to achieve maximal derivatization was determined using a concentration gradient. The MMPA was detected using a fluorescence detector (excitation $=385 \mathrm{~nm}$, emission $=515 \mathrm{~nm}$ ) and $0.1 \%$ TFA and acetonitrile as the mobile phases. Following this protocol, MMPA standard curves were linear $\left(\mathrm{R}^{2}=.993\right)$ down to $1 \mu \mathrm{M}$, However, the MPA signal following this protocol was 4 times greater than the MMPA signal indicating incomplete derivatization of MMPA. We believe this is due to the methyl group on the sulfur which most likely is inhibiting the derivatization with SBD-F; MPA does not have the extra methyl group leaving the sulfur free and the derivatization uninhibited. As a result of this inhibition, the MMPA signal is not large enough to see over the background of tetrahydrofolate.

2-nitrophenyl hydrazine (NPH) was derivatized to the carboxylic group in MMPA following the protocol of Albert and Martens [1997]. The protocol is provided as Appendix $L$. Two different derivatization temperatures were tested, $50^{\circ} \mathrm{C}$ for 15 minute [Peters et al.], and $28^{\circ} \mathrm{C}$ for 1.5 hours [Albert and Martens, 1997]. No difference in derivatization efficiency was found between the two temperatures. Following this protocol, MMPA standard curves were linear to $1 \mu \mathrm{M}\left(\mathrm{R}^{2}=0.999\right)$. Standards of formic acid $\left(\mathrm{R}^{2}=0.999\right)$ and propionic acid $\left(\mathrm{R}^{2}=0.999\right)$ were also tested. DMSP was not efficiently derivatized by NPH. Though the NPH derivatized MMPA signal was significantly greater than the SBD-F derivatized signal, the THF degradation products still obscured the MMPA peak. We believe that this is due to an unidentified THF degradation product which contains a carboxylic group and is similar in size and structure to MMPA. To minimize THF degradation during the assay, the assay was run 
completely anaerobically; all work was done in an anaerobic glove bag. In addition, the HPLC mobile phases were heated to $40^{\circ} \mathrm{C}$, bubbled vigorously for 20 minutes with $\mathrm{N}_{2}$, and modified to contain DDT. DDT was used as titanium citrate caused a precipitate to form in the mobile phases. Despite these precautions, significant THF degradation was observed and the MMPA peak was still obscured. We believe that the observed THF degradation may in part be due to the $\mathrm{pH}$ required for $\mathrm{NPH}$ derivatization.

As the direct detection of MMPA was unsuccessful, we attempted to detected the modified co-factor (methyl-THF) following Reisch et al.'s [2008] protocol (see Appendix $M$ ). While standard curves of methyl-THF were linear to $25 \mu \mathrm{M}$, the HPLC peaks were not cleanly separated. In addition, tests indicated that there was degradation of methylTHF during the HPLC runs (a single peak was seen to degrade into two other peaks). Methyl-THF is also sensitive to oxygen, light and $\mathrm{pH}$. The degradation of the compound on which the enzyme rate is based is problematic. Therefore, we hesitate to use methylTHF to quantify the transfer of DMSP to MMPA.

A final method of MMPA detection was tested, cleavage of MMPA to methanethiol. DMSP is quantified by degradation to DMS using alkaline hydrolysis. If the same protocol worked for MMPA, the result would be the production of methanethiol, which is easily quantified on a gas chromatograph. However, alkaline hydrolysis was shown to have no effect on MMPA.

A final protocol for bacterial DMSP demethylation potential enzyme activity was unfortunately not achieved. We were unable to minimize the degradation of THF enough to see the MMPA peak. This method could be successful if one is able to remove the 
THF from the assay following the reaction period- perhaps with spin filtration. Alternatively, it may be possible to separate the peaks using a different HPLC column or mobile phases. However, this will be difficult as there are numerous $(>20)$ THF degradation peaks. A truly anoxic HPLC system could decrease the degradation of THF during the HPLC runs. Finally, a dual derivatization (e.g. SBD-F and NPH) might allow for the detection of MMPA by monitoring both wavelengths. A test with a culture of Silicibacter pomeroyi showed the appearance of MPA, the secondary product of the demethylation pathway, during the assay. This result indicates that this method might be successful if one is able to separate the MMPA and THF peaks. 


\section{REFERENCES:}

Albert, D. B., and C. S. Martens (1997), Determination of low-molecular-weight organic acid concentrations in seawater and pore-water samples via HPLC, Marine Chemistry, 56(1-2), 27-37.

Breznak, J. A., and R. N. Costilow (1994), Physicochemical factors in growth, in Methods for general and molecular bacteriology, edited by P. Gerhardt, pp. 137-154, American Society for Microbiology (ASM).

Howard, E. C., et al. (2006), Bacterial taxa that limit sulfur flux from the ocean, Science, 314, 649-652.

Peters, R., et al. (2004), On-line determination of carboxylic acids, aldehydes and ketones by high-performance liquid chromatography-diode array detection-atmospheric pressure chemical ionisation mass spectrometry after derivatization with 2-nitrophenylhydrazine, Journal of Chromatography A, 1031(1-2), 35-50.

Reisch, C. R., et al. (2008), Dimethylsulfoniopropionate-Dependent Demethylase (DmdA) from Pelagibacter ubique and Silicibacter pomeroyi, Journal of Bacteriology, 190(24), 8018-8024.

Smith, M. H., and S. L. Woods (1994), Comparison of Reactors for Oxygen-Sensitive Reactions - Reductive Dechlorination of Chlorophenols by Vitamin-B-12s, Applied and Environmental Microbiology, 60(11), 4107-4110.

Tang, D. G., et al. (2000), Analysis of biogenic thiols in natural water samples by highperformance liquid chromatographic separation and fluorescence detection with ammonium 7-fluorobenzo-2-oxa-1,3-diazole-4-sulfonate (SBD-F), Analytica Chimica Acta, 408(1-2), 299-307.

Zhang, J. Z., et al. (2004), Thiols in wetland interstitial waters and their role in mercury and methylmercury speciation, Limnology and Oceanography, 49(6), 2276-2286. 


\section{Appendix D}

\section{Phytoplankton Lyase Enzyme Activity}

after Harada et al, 2004

- Tris Buffer: 200mM prepared in 500mM NaCl, pH 8.0 (autoclaved and filter sterilized)

- DMSP-HCl: $250 \mathrm{mM}$

- Underway water bath

- Temperature probe

1) Collect water from Niskin

a. Collect $\sim 4 \mathrm{~L}$ per depth, place carboys inside lab to keep cool

2) Filter $500 \mathrm{ml}$ onto $25 \mathrm{~mm}$ autoclaved $1.2 \mu \mathrm{m} \mathrm{GF} / \mathrm{C}$ filter (measure with graduated cylinder) using a polycarbonate funnel filter holder and gentle filtration $(<0.02 \mathrm{~Pa})$.

3) Place filter in $14 \mathrm{~mL}$ amber glass serum bottle with $1 \mathrm{~mL}$ Tris buffer and cap with rubber stopper (do not crimp).

a. Place filter face down in Tris and make sure it stays flat along the bottom and doesn't get stuck to the sides.

4) Vortex each vial 10sec to break up filter

5) Incubate for 20 min in underway seawater bath

6) Add $20 \mu \mathrm{L}$ DMSP- $\mathrm{HCl}$ (final concentration $5 \mathrm{mM}$ ) and crimp immediately

7) Vortex vigorously for $10 \mathrm{sec}$

8) Press start on timer and immediately remove $100 \mu \mathrm{L}$ headspace and inject onto the GC (flush the needle 2-3 times before removing the headspace)

9) Every $2 \mathrm{~min} 15 \mathrm{sec}$ vortex the sample for $2-5$ seconds, extract $100 \mu \mathrm{l}$ of headspace, and inject onto the GC. Record the exact time that the headspace was removed. Collect 4-5 good peaks.

a. If a peak saturates the detector: decrease the injection volume. Record new injection volume so that the standard curve can be corrected accordingly.

10) At the end of the run record the min and max temperature of the water bath 


\title{
Appendix E
}

\section{Bacterial Cleavage Enzyme Activity}

\author{
N. Levine, WHOI 2008
}

Modified from Harada et al, 2004

- Tris Buffer: 200mM prepared in 500mM NaCl, pH 8.0 (autoclaved and filter sterilized)

- DMSP-HCl: 250mM

- Underway water bath

- Temperature probe

11) Pre-filter off niskin using an in-line $47 \mathrm{~mm}$ polycarbonate filter holder (Pall Life Sciences) containing a $1.2 \mu \mathrm{m}$ glass fiber filter. Collect $4 \mathrm{~L}$ in Nalgene carboy and place inside lab to keep cool.

12) Filter $400 \mathrm{ml}$ onto $0.2 \mu \mathrm{m}$ PC filter ( $30 \mathrm{~min}$, filter larger volume if filters faster, measure volume with graduated cylinder and record) using a polycarbonate funnel filter holder and gentle filtration $(<0.02 \mathrm{~Pa})$.

13) Place filter in $14 \mathrm{~mL}$ amber glass serum bottle with $1 \mathrm{~mL}$ Tris buffer cap with rubber stopper (do not crimp)

a. Place filter face down in tris and make sure that it stays flat along the bottom and doesn't get stuck to the sides.

14) Vortex each vial $10 \mathrm{sec}$ (if filter gets stuck on wall, put back on bottom)

15) Incubate for $20 \mathrm{~min}$ at in underway seawater bath

16) Add $20 \mu \mathrm{L}$ DMSP-HCl (final concentration $5 \mathrm{mM}$ ) and crimp immediately

17) Vortex vigorously for $10 \mathrm{sec}$

18) Press start on timer and immediately remove $100 \mu \mathrm{L}$ headspace and inject onto the GC (I flush the needle 2-3 times before removing the headspace)

19) Every 2 min vortex the sample for $2-5$ seconds, extract $100 \mu l$ of headspace, and then inject onto the GC. Record the exact time that the headspace was removed. Collect 4-5 good peaks.

20) At the end of the run record the min and max temperature of the water bath 


\section{Appendix F}

\section{DNA extraction protocol \\ Modified from R. Parsons, BIOS}

1. Put 4 filters into $15 \mathrm{ml}$ falcoln tube and add $\mathbf{5 m l}$ Sucrose Lysis Buffer (recipe below) solution, 500 $\mathbf{\mu l} 10 \%$ sodium dodecyl sulfate, $2 \boldsymbol{\mu}$ l Proteinase $\mathrm{K}$ (100ug/ml)

2. Incubate $30 \mathrm{~min}$ at $37^{\circ} \mathrm{C}$

3. Incubate $30 \mathrm{~min}$ at $55^{\circ} \mathrm{C}$

4. Transfer liquid ( $1 \mathrm{ml}$ at a time) into new $15 \mathrm{ml}$ falcoln tube for $\left(1^{\mathrm{st}} \mathrm{set}\right)$

5. Bring liquid up to $6 \mathbf{m l s}$ with TE buffer

6. Add 6 mls of phenol-chloroform-isoamyl alcohol (25:24:1 pH 8) solution to tubes

7. Centrifuge $6,500 \mathrm{rpm}$ for $10 \mathrm{~min}$ at $4^{\circ} \mathrm{C}, \quad\left(4-6\right.$ for $2^{\text {nd }}$ set $)$

8. Transfer 5.5-6 mls of top aqueous layer and place in new $15 \mathrm{ml}$ falcoln tube ( $\mathbf{1}^{\text {st }}$ set)

9. Add $\mathbf{5 . 5}$ mls of phenol-chloroform-isoamyl alcohol (25:24:1 $\mathrm{pH} 8)$ solution

10. Centrifuge $6,500 \mathrm{rpm}$ for $10 \mathrm{~min}$ at $4^{\circ} \mathrm{C} \quad\left(8-10\right.$ for $2^{\text {nd }}$ set $)$

11. Transfer $\mathbf{5 - 5 . 5} \mathbf{~ m l s}$ of top aqueous layer and place in new $15 \mathrm{ml}$ falcoln tube ( $\mathbf{1}^{\text {st }}$ set)

12. Add $\mathbf{5} \mathbf{~ m l}$ of chloroform-isoamyl alcohol (24:1)

13. Centrifuge $5,000 \mathrm{rpm}$ for $5 \mathrm{~min} 4^{\circ} \mathrm{C}\left(\mathbf{1 1 - 1 2}\right.$ for $2^{\text {nd }}$ set $)$

14. Transfer $4.5-5 \mathrm{mls}$ of top aqueous layer to new $15 \mathrm{ml}$ tube

15. Add $2.5 \mathrm{ml} 7.5 \mathrm{M}$ ammonium acetate (sample: ammonium acetate $2: 1$ )

16. Add $\mathbf{5 m l s}$ isopropanol $-20^{\circ} \mathrm{C}$ (sample:iso $1: 1$ )

17. Incubate overnight at $-20^{\circ} \mathrm{C}$

18. Centrifuge max $(10,000 \mathrm{xg})$ for $30 \mathrm{~min} 4^{\circ} \mathrm{C}$

19. Decant supernatant carefully. Invert tube on Kim-wipe to remove excess ethanolDRY

20. Resuspend in 500ul TE buffer and put in $2 \mathrm{ml}$ tube

21. Add 250ul 7.5M ammonium acetate

22. Add 500ul isopropanol $-20^{\circ} \mathrm{C}$

23. $-\mathbf{2 0}{ }^{\circ} \mathrm{C}$ for 2 hours. 
24. Centrifuge $\max (14,000 \mathrm{rpm})$ for $\mathbf{3 0 m i n}$

25. Decant supernatant carefully

26. Add $1 \mathrm{ml}$ cold $80 \%$ ethanol, vortex $30 \mathrm{secs}$

27. Spin $\max (14,000 \mathrm{rpm})$ for $\mathbf{1 0} \mathbf{~ m i n s}$ at $4^{\circ} \mathrm{C}$.

28. Dry pellet (RT or in speed vac or $37^{\circ} \mathrm{C}$ in hyb oven)

29. Store dried pellet at -20 .

\title{
Sucrose Lysis Buffer
}

\author{
from Rachel Parsons
}

\section{0mM EDTA (7.16g) \\ 400mM NaCl (23.38g) \\ 0.75M Sucrose (256.7g) \\ 50mM Tris.HCl pH 9.0 (6.06g base)}

1. Resuspend Tris base and EDTA in 300mls QW.

2. Adjust $\mathrm{pH}$ to 9.0 with $\mathrm{HCl}$.

3. Add $\mathrm{NaCl}$ and Sucrose and bring to $800 \mathrm{ml}$ with Qw.

4. Heat gently with stirring.

5. When in solution, bring to $1 \mathrm{~L}$.

6. Filter sterilize and aliquot into $50 \mathrm{ml}$ tubes. Freeze at $-20^{\circ} \mathrm{C}$ 


\title{
Appendix G
}

\author{
RNA Extraction From Filters \\ Adapted from Dauphin Island Protocol, Moran lab UGA
}

1. Prepare bead-beating tubes: Each $2 \mathrm{~mL}$ tube contains $.2 \mathrm{~mL}$ of $0.1 \mathrm{~mm}$ Zirconia beads, 3 large beads

2. For each sample, filter $\mathbf{4} \times \mathbf{1 5 m i n}$ seawater onto $47 \mathrm{~mm}, 0.2 \mu \mathrm{m}$ autoclaved polycarbonate filters. Flash freeze in liquid $\mathrm{N}_{2}$

3. Take filters out of liquid $\mathrm{N}_{2}$, place in bead-beating tubes with $\underline{500 \mu \mathrm{L} \text { of buffer }}$

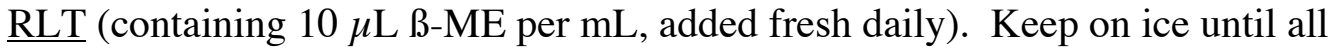
filters have been transferred.

4. Place tubes on a vortex adaptor and beat for $\mathbf{1 0}$ minutes at top speed.

5. Remove from vortex and centrifuge $8,500 \times \mathbf{g}, 1 \mathrm{~min}$. Transfer supernatant to a clean $2 \mathrm{ml}$ tube.

6. Add 100 $\boldsymbol{\mu l}$ RLT buffer to bead-beating tube, vortex, centrifuge briefly, add supernatant to tube from step 5.

7. Centrifuge $8,5000 \times \mathbf{~ g}, 1 \mathrm{~min}$. Transfer supernatant to new tube

8. Add 600pl of $70 \%$ ethanol to the lysate. Draw the lysate up through an 20 gauge needle and pass it back out several (4) times to shear DNA

9. Apply $700 \mu \mathbf{L}$ of the sample to an RNeasy mini spin column. Centrifuge $30 \mathrm{sec}$ at $10000 \mathrm{x}$ g. Discard flow-through. Repeat until the entire sample has been applied to the column. Combine supernatant from all 4 filters from the same sample onto one spin column.

10. Add $350 \mu \mathbf{L}$ Buffer RW1 to the column. Centrifuge $30 \mathrm{sec}$ at $10000 \mathrm{x} \mathrm{g}$ to wash. Discard the flow-through.

11. Combine $10 \mu \mathrm{l}$ DNase-I with $70 \mu \mathrm{l}$ RDD buffer. Add 80 $\mu$ l solution directly onto spin column and incubate at R.T. for $15 \mathrm{~min}$.

12. Add $350 \mu \mathbf{L}$ Buffer RW1 to the column. Centrifuge $30 \mathrm{sec}$ at $10000 \mathrm{x}$ g. Discard the flow-through. 
13. Transfer the spin column to a new collection tube. Add $500 \mu \mathbf{L}$ Buffer RPE to the spin column. Centrifuge 15 seconds at $10000 \mathrm{x}$ g. Discard flow-through.

14. Add another $\mathbf{5 0 0} \boldsymbol{\mu} \mathbf{L}$ Buffer RPE to the spin column. Centrifuge $2 \mathrm{~min}$ at $10000 \mathrm{x}$ g. Discard flow-through.

15. Place spin column in new collection tube (not supplied) and spin an additional 1 min at full speed to get rid of ethanol.

16. Add $35 \boldsymbol{\mu l}$ RNase-free water directly onto spin column. Let stand for $1 \mathrm{~min}$ and then centrifuge for $1 \mathrm{~min}$ at $10000 \mathrm{x} \mathrm{g}$.

17. Add $15 \boldsymbol{\mu l}$ RNase-free water directly onto spin column. Let stand for $1 \mathrm{~min}$ and then centrifuge for $1 \mathrm{~min}$ at $10000 \mathrm{x} \mathrm{g}$. 


\section{Appendix H}

\section{qPCR Protocol}

1. $95^{\circ} \mathrm{C}-3 \min 30 \mathrm{~s}$

2. Then $40-45$ cycles of
a. $95^{\circ} \mathrm{C}-20 \mathrm{~s}$
b. Primer specific annealing temperature $-30 \mathrm{~s}$
c. $72^{\circ} \mathrm{C}-30 \mathrm{~s}$

3. $95^{\circ} \mathrm{C}-1.0 \mathrm{~min}$

4. Primer specific annealing temperature $-1.0 \mathrm{~min}$

The melt curve was run with a $0.5^{\circ} \mathrm{C}$ increase every 10 s for 81 cycles

For RT-qPCR a $10 \mathrm{~min} 50^{\circ} \mathrm{C}$ step was inserted before step 1.

Primer specific annealing temperatures:

- $\quad d m d A \mathrm{~A} / 1=53^{\circ} \mathrm{C}$

- $\quad d m d A \mathrm{~A} / 2=59^{\circ} \mathrm{C}$

- $\quad d m d A \mathrm{~B} / 3=62^{\circ} \mathrm{C}$

- $d m d A \mathrm{C} / 2=50^{\circ} \mathrm{C}$

- $\quad d m d A \mathrm{D} / 1=49^{\circ} \mathrm{C}$

- $d m d A \mathrm{D} / 3=54^{\circ} \mathrm{C}$

- $d m d A \mathrm{E} / 2=57^{\circ} \mathrm{C}$

- $d d d P=41^{\circ} \mathrm{C}$ 


\section{Appendix I}

\section{MMPA Synthesis}

Methylthiopropionate (MMPA)

Methyl-3-(methylthio)propionate (methyl-MMPA)

7.03mM MMPA synthesis at room temperature:

400ul 20mM methyl-MMPA

$+285.6 \mu 17 \mathrm{M} \mathrm{NaOH}$

$+114.4 \mu 1 \mathrm{H}_{2} \mathrm{O}$

sit for $10 \mathrm{~min}$

$+338.4 \mu 150 \% \mathrm{HCl}$ 


\author{
Appendix J \\ 0.35M Titanium (III) citrate (Smith and Woods, 1994 AEM) \\ In lab: \\ - $14.7 \mathrm{~g} \mathrm{Na}$-citrate $+8.0 \mathrm{~g}$ Tris base $+40 \mathrm{ml} \mathrm{H}_{2} \mathrm{O}$ (autoclave) \\ In anaerobic glove box: \\ - $22.5 \mathrm{ml} \mathrm{Ti}(\mathrm{III}) \mathrm{Cl}_{3}$ \\ - Adjust volume to $100 \mathrm{ml}$ \\ - Adjust $\mathrm{pH}$ to 8 with $\mathrm{NaOH}$ \\ - Freeze $15 \mathrm{ml}$ aliquots for later use.
}




\section{Appendix K}

\section{SBD-F: MMPA HPLC Protocol}

Derivatization:

Modified from Tang et al. [2000] and Zhang et al. [2004]

SBD-F --- fluorogenic reagent ammonium-7-florobenzo-2-oxa-1,3-diazole-4-sulfonate

$1 \mathrm{mg} / 4 \mathrm{ml}$ prepared in $2 \mathrm{M} \mathrm{K}$-borate buffer ( $\mathrm{pH} 9.5$ )

\section{Derivatization step:}

$100 \mu \mathrm{l}$ sample

$+10 \mu 110 \%$ phosphoric acid (to quench enzyme activity)

$+40 \mu 1$ 40mM SBD-F

$+50 \mu l 1 \mathrm{M} \mathrm{NaOH}$

$+200 \mu \mathrm{l}$ borate buffer, $0.1 \mathrm{M}$ containing $2 \mathrm{mM}$ EDTA at $\mathrm{pH} 9.5$

Incubate $60^{\circ} \mathrm{C}$ for $60 \mathrm{~min}$

Stop with $100 \mu 11 \mathrm{M}$ methanesulfonic acid

10 min on ice

\section{HPLC Analysis:}

Mobile phase A: $0.1 \%$ TFA in water

Mobile phase $B$ : acetonitrile $(\mathrm{A} \%=100 \%-\mathrm{B} \%)$

Column: Agilent Eclipse XDB-C18

Elution profile: gradients were linear in all steps except for last step where B was instantly dropped from 100 to $0 \%$

\begin{tabular}{|l|l|}
\hline \multicolumn{1}{|c|}{ Time } & \multicolumn{1}{c|}{$\% \mathbf{B}$} \\
\hline $0-5 \mathrm{~min}$ & $0 \%$ \\
\hline $5-10 \mathrm{~min}$ & $0-10 \%$ \\
\hline $10-12 \mathrm{~min}$ & $10 \%$ \\
\hline $12-14 \mathrm{~min}$ & $10-11.5 \%$ \\
\hline $14-26 \mathrm{~min}$ & $11.5-14 \%$ \\
\hline $26-30 \mathrm{~min}$ & $14-100 \%$ \\
\hline $30-35 \mathrm{~min}$ & $100 \%$ \\
\hline $35-40 \mathrm{~min}$ & $0 \%$ \\
\hline
\end{tabular}

Column Temperature: $30^{\circ} \mathrm{C}$

Flow rate: $1 \mathrm{ml} / \mathrm{min}$

Sample size: $50 \mu 1$

Fluorescence detector: excitation mode- $385 \mathrm{~nm}$

Gain: 16

Emission mode- 518nm 


\title{
Appendix L
}

\author{
NPH MMPA HPLC Protocol \\ After Albert and Martens 1997 MC, Peters et al 2004 JC
}

\section{Derivatization:}

2-nitrophenyl hydrazine (NPH) recrystallize from hot water

1-ethyl-3-(3-dimethylaminopropyl) carbodiimide hydrochloride (EDC)

Pyridine

\section{Solutions}

NPH: .1M NPH in .25M HCl

$76.6 \mathrm{mg} \mathrm{NPH}+5 \mathrm{ml} .25 \mathrm{M} \mathrm{HCl}$

EDC: $3 \mathrm{M} \mathrm{EDC}$ in Q-water

287.6mg EDC + 5ml Q-water

Pyridine: 1 pyridine: 1 concentrated $\mathrm{HCl}$

\section{Derivatization step:}

$200 \mu$ sample

$+40 \mu l$ pyridine

$+40 \mu 1 \mathrm{NPH}$

$+40 \mu \mathrm{EDC}$

Mix

Incubate $1 \frac{1}{1} 2-2 \mathrm{hrs}$ at room temperature Mix

\section{HPLC Analysis:}

Mobile phase A: $2.5 \%$ butanol

$50 \mathrm{mM}$ Sodium Acetate

$2 \mathrm{mM}$ tetrabutylammonium hydroxide

$2 \mathrm{mM}$ tetradecyltrimethylammonium bromide

Mobile phase B: same as A except

$50 \mathrm{mM}$ tetradecyltrimethylammonium bromide

Column: Agilent Eclipse XDB-C18

Elution profile: gradients were linear in all steps except for last step where B was instantly dropped from 100 to $0 \%$ 


\begin{tabular}{|l|l|l|l|}
\hline Time & $\% \mathrm{~A}$ & $\% \mathrm{~B}$ & Flow rate \\
\hline $0-5 \mathrm{~min}$ & 100 & & $1.5 \mathrm{ml} / \mathrm{min}$ \\
\hline $5-15 \mathrm{~min}$ & & 100 & $1.5 \mathrm{ml} / \mathrm{min}$ \\
\hline $15-30 \mathrm{~min}$ & & 100 & $1.3 \mathrm{ml} / \mathrm{min}$ \\
\hline $30-40 \mathrm{~min}$ & 100 & & $1.5 \mathrm{ml} / \mathrm{min}$ \\
\hline
\end{tabular}

Column Temperature: $30^{\circ} \mathrm{C}$

Sample size: $100 \mu \mathrm{l}$

Diode Array: 400 nm, band width 20nm 


\section{Appendix M}

\section{5-Methyl-THF Detection}

Following C. Reisch's protocol 2007

Standard curves of 5-methyl-tetrahydrofolate (methyl-THF) made up in anaerobic glove bag detected using:

\section{HPLC Analysis:}

Mobile phase A: $0.204 \% \mathrm{H}_{3} \mathrm{PO} 4\left(1 \mathrm{~L} \mathrm{H}_{2} \mathrm{O}+2.401 \mathrm{ml} 85 \% \mathrm{H}_{3} \mathrm{PO}_{4}\right)$

Mobile phase B: Acetonitrile

Column: Agilent Eclipse XDB-C18

Elution profile:

\begin{tabular}{|l|l|l|l|}
\hline Time & $\% \mathrm{~A}$ & $\% \mathrm{~B}$ & Flow rate \\
\hline $0-15 \mathrm{~min}$ & 98 & 2 & $0.75 \mathrm{ml} / \mathrm{min}$ \\
\hline
\end{tabular}

Column Temperature: $30^{\circ} \mathrm{C}$

Sample size: $100 \mu \mathrm{l}$

Detection: $280 \mathrm{~nm}$, bandwidth 10 